BUDAPESTI CORVINUS EGYETEM

\title{
A FELKELÉSELLENES HADVISELÉS LAKOSSÁGKÖZPONTÚ ELMÉLETÉNEK FEJLÖDÉSE A XX-XXI. SZÁZADBAN
}

PH.D. ÉRTEKEZÉS

Kemény János

Budapest, 2014 
Kemény János 
Nemzetközi Tanulmányok Intézet

Témavezető:

Békés Csaba Ph.D. egyetemi tanár

CC Kemény János 


\section{Budapesti Corvinus Egyetem \\ Nemzetközi és Biztonsági Tanulmányok alprogram}
A felkelésellenes hadviselés lakosságközpontú elméletének fejlődése a XX-XXI. században

Ph.D. értekezés

Kemény János

Budapest, 2014 



\section{Tartalomjegyzék}

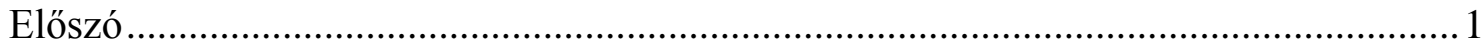

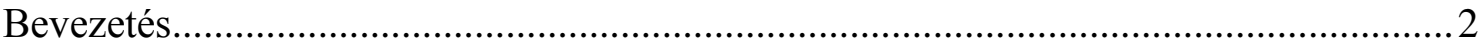

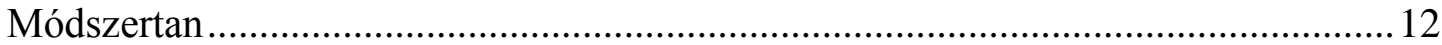

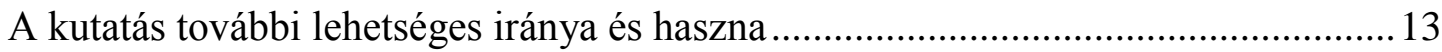

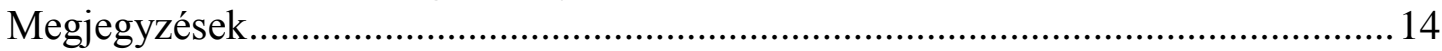

Definíciók és a felkelésellenes hadviselés elméleti behatárolása .............................. 15

I.FEJEZET A FELKELÉS PROBLEMATIKÁJA A KLASSZIKUS SZAKASZ

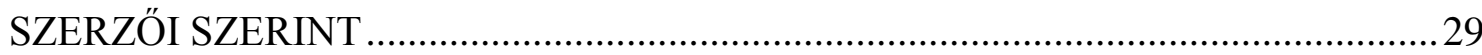

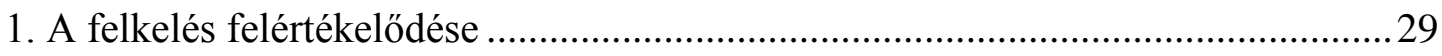

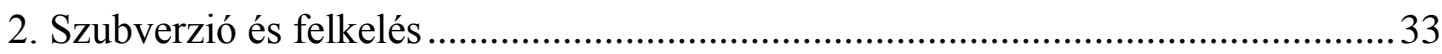

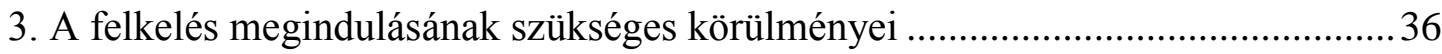

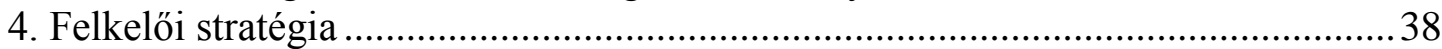

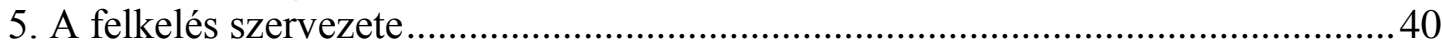

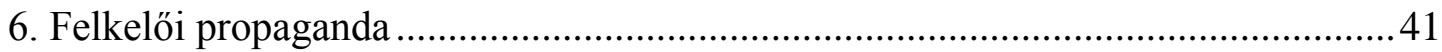

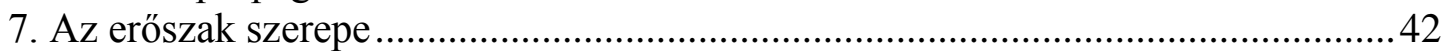

II. FEJEZET A BRIT FELKELÉSELLENES ELMÉLET FEJLÖDÉSE …...................47

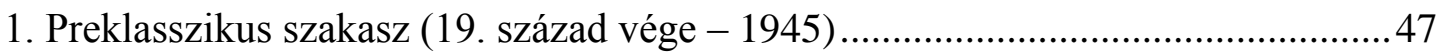

1. Doktrínák a 20. század első felében .................................................................. 48

2. Az ír függetlenségi háború (1919-1921) szerepe .............................................50

3. A két világháború közötti brit tevékenység a gyarmatokon..............................51

4. Brit nem konvencionális tevékenység a második világháború alatt ..................52

5. A témában megjelent fontosabb müvek .........................................................5 53

2. Klasszikus szakasz: Brit felkelésellenes műveletek és doktrínák a második

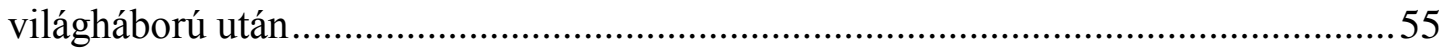

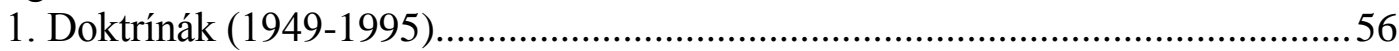

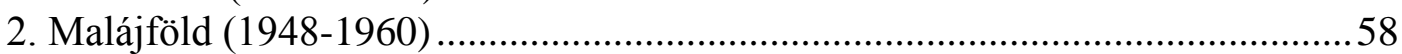

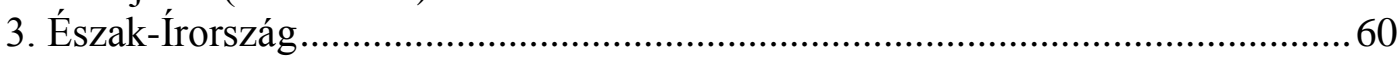

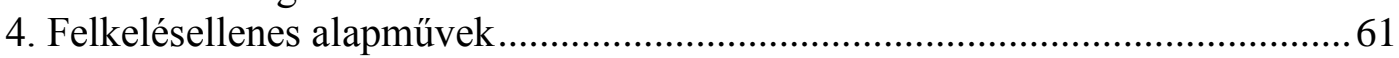

1. Robert Grainger Ker Thompson: A kommunista felkelés legyőzése...............61

2. Frank Kitson: Alacsony intenzitású müveletek ...........................................66

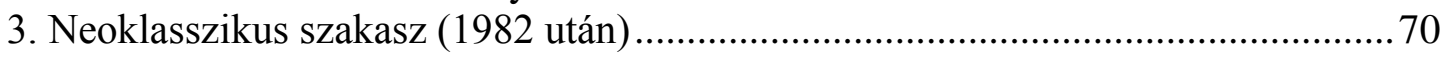

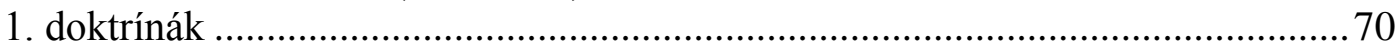

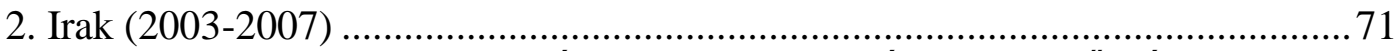

III. FEJEZET A FRANCIA FELKELÉSELLENES ELMÉLET FEJLÖDÉSE.............73

1. Preklasszikus szakasz. A 19. század közepétől a második világháborúig ...............73

2. Klasszikus szakasz. A második világháború és utóélete..........................................77

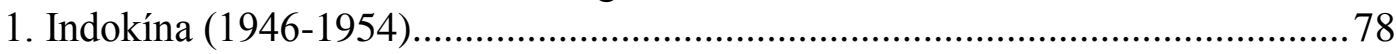

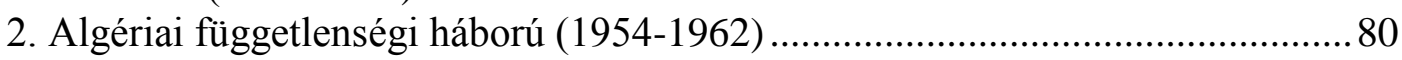

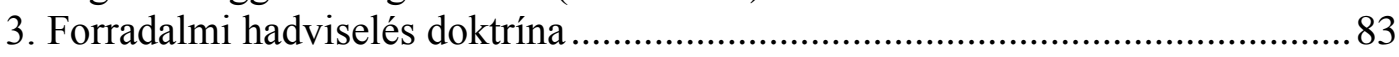

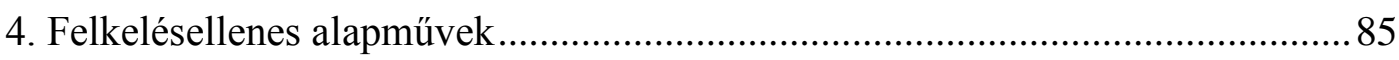

1. Roger Trinquier: Modern hadviselés ..................................................... 85

2. David Galula: Felkelésellenes hadviselés. Elmélet és gyakorlat .................. 92

3. Neoklasszikus szakasz (1982 után) ................................................................ 100

IV. FEJEZET AZ USA FELKELÉSELLENES ELMÉLETÉNEK FEJLŐDÉSE ........101

1. Preklasszikus szakasz: Felkelésellenes konfliktusok a kezdetektől a második világháború végéig (1898-1945) 
2. Klasszikus szakasz: Felkelésellenes doktrínák a második világháború végétől 1982-ig

3. Neoklasszikus szakasz: Felkelésellenes doktrínák 1982 után.............................121

V. FEJEZET A FELKELÉSEK MODERN PROBLÉMÁI......................................... 128

1. A felkelés fogalmának változása a klasszikus értelmezéshez képest....................128

2. Dzsihádi felkelő stratégia: Mukrin és Nádzsi ................................................... 130

3. A változás egyéb vetületei .................................................................................. 133

VI. FEJEZET HARMADIK SZEREPLŐS FELKELÉSELLENES HADVISELÉS ... 137

Mi a harmadik szereplős felkelésellenes hadviselés? .............................................. 137

A harmadik szereplő és katonai kihívásai, strukturális problémái............................ 142

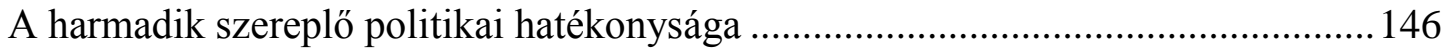

A megsegített ország kulturális sajátosságai jelentette kihívások..............................152

A felkelések és felkelésellenes müveletek elemzése és politikai nehézségeik ......... 153

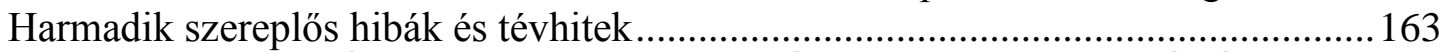

VII. FEJEZET KORTÁRS NYUGATI FELKELÉSELLENES DOKTRÍNÁK...........165

USA FM 3-24 Felkelésellenes müveletek................................................................. 166

NATO 3.4.4 Szövetséges Összhaderőnemi Publikáció ............................................ 168

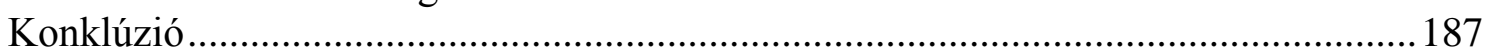

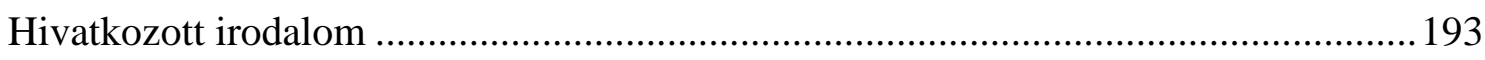

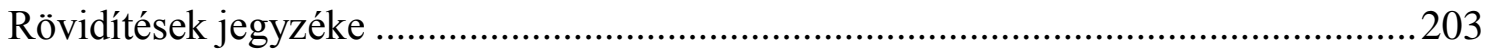

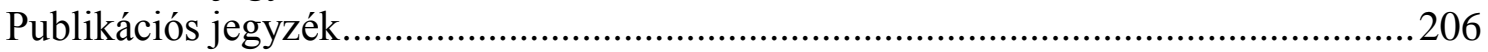




\section{Táblázatjegyzék}

1. táblázat Konvencionális jellegü államközi háborúk a szükebb konfliktusos

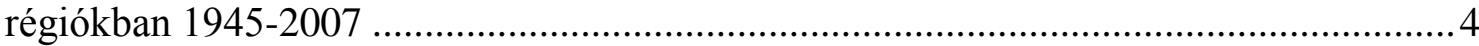

2. táblázat A szükebb konfliktusos régiókon kívül eső konvencionális államközi háborúk 1945-2007

3. táblázat A maoi három fázis a felkelők és az ellenség szemszögéből..................... 33

4. táblázat Fall-féle nem katonai indikátorok .......................................................... 156

5. táblázat Adott kormány teljesítményére vonatkozó nem katonai faktorok ...........158

6. táblázat Az iraki jelentésekben alkalmazott indikátorok 2005-2010................... 162 
„,...) a gyözelem és vereség közti különbség nyitja a forradalmi háborúban, hogy a lakosság és a hadsereg ,ugyanazon az oldalon legyen és harcoljon”. (...) Ezért olyan fontos megérteni, hogy a gerilla hadviselés nem különleges, hanem taktikai kiegészitője egy sokkal nagyobb politikai vetélkedésnek, és attól függetlenül, hogy mennyire szakértö módon vívják meg kompetens és elhivatott szakértők, lehetetlen, hogy pótolja a politikai alapokat."

Bernard Fall: Street Without Joy 375. o. 



\section{Előszó}

A felkelésellenes hadviselés elméletének fejlődése egy méltatlanul kevéssé vizsgált szegmens napjaink katonai beavatkozásainak kutatásában. A jelen disszertáció egyik kutatási kérdése az volt, hogy az Egyesült Államok és szövetségesei miért nem voltak képesek úrrá lenni az Irakban és Afganisztánban tapasztalt kihíváson?

Az Irakban történtek nagyon látványosak voltak abból a szempontból, hogy az Egyesült Államok és szövetségesei haderőinek gyors konvencionális győzelmét néhány hónappal követte egy olyan felkelés, amelyen látszólag nem tudtak úrrá lenni ugyanazok az erők - Bush elnök 2003. május 1-jén jelentette be a nagyarányú katonai müveletek befejezését, vagyis a győzelmet, a merényletek pedig 2003 augusztusában kezdődtek. Ezzel párhuzamosan Afganisztánban a 2002-re legyőzöttnek hitt tálib mozgalom részben a pakisztáni határvidéki menedéke segítségével néhány év alatt újra jelentős fenyegetéssé tudott válni, amit az amerikai és koalíciós erők szintén nem tudtak semlegesíteni.

A helyzet azért is ellentmondásos, mert az Egyesült Államok hatalmas összegeket fordít a védelmi kapacitásaira és olyan egyedi kapacitásokkal rendelkezik, amilyenekkel senki más. A mindenkori ellenség a két országban ezzel szemben minimális erőforrással és eszközrendszerrel bír. Az évek során számos magyarázat született a sikertelenségre: a katonai erő megváltozott jellegével és alkalmazásával, a koalíciós jelleggel, a nemzetközi rendszer átstrukturálódásával, az erő alkalmazásához kötődő viszony megváltozásával, a globalizáció kiegyenlítő hatásaival stb. magyarázták. A másik népszerü magyarázat a felkelések jellegének megváltozása, amelynek következtében a felkelések részben az elöbb említett trendeket kihasználva nagyon nehezen kezelhető fenyegetésekké váltak.

A kérdés kapcsán a szerző arra jutott, hogy nem elég az iraki vagy éppen az afganisztáni eseményeket vizsgálni, - az alapvető elméleti kérdéseket kell tisztázni az erő alkalmazása kapcsán a problémák feltáráshoz. Ez pedig a felkelésellenes hadviselés elméletének és fejlödésének alapos körüljárását igényli. A kérdés vizsgálata számos nehézséget rejt magában, mivel számos elöítélet és tévhit alakult ki a felkelésellenes hadviseléssel kapcsolatban részben katonai, részben politikai okok miatt. A tévhitek közül talán a legalapvetőbb és máig ható az, hogy nyugati országok képtelenek felülkerekedni az ilyen konfliktusokban. A disszertáció célja, hogy ezeket a kérdéseket és problémákat tisztázza. 


\section{Bevezetés}

Napjaink nemzetközi rendszerének vizsgálatakor a bukott és instabil államok kapcsán folyamatosan jelen van a nemzetközi katonai szerepvállalás témája. Ez szorosan kapcsolódik az erő alkalmazásának és változásának kérdéséhez a nemzetközi rendszerben. Ahogyan megnőtt az államok száma és átalakult a kapcsolatrendszere, az erő alkalmazásának szabályai is jelentősen megváltoztak a második világháború után, a hidegháború végével pedig az erő alkalmazása is új politikai kontextusba került, annak váratlan hatásai miatt. A kirobbant konfliktusok miatt ismét elötérbe került a békefenntartás, valamint új kategóriák jelentek meg, mint pl. a humanitárius beavatkozás.

Alapvető változás történt a háború fogalmát illetően, annak hagyományos értelmében: „A háború megszünt. Konfrontáció, konfliktus és fegyveres harc természetesen továbbra is van világszerte, (...) és az államok fenntartanak fegyveres eröket, amelyeket a hatalom szimbólumaként használnak. Ennek ellenére a háború, ahogyan azt a nem kombattáns ismeri, a háború, mint emberek és gépek közötti harc, a háború, mint hatalmas és döntő esemény a nemzetközi konfliktusok megoldására: ez a háború már nem létezik." (Smith [2008] 3. o.)

Roger Trinquier, a francia hadsereg ezredese már a hatvanas évek elején hasonlóan vélekedett: „A tradicionális fegyveres erőknek nincs már meg a megszokott döntö jellegük. A győzelem többé nem egy csatától függ adott terepen. A katonai müveletek, mint a harc egy ellenséges fegyveres erövel szemben, csak korlátozott fontossággal bírnak, és soha nem a konfliktus egészét jelentik. Ez kétségtelenül az oka annak, hogy a hadsereg, amely tradicionálisan a katonai aspektusa egy konfliktusnak, soha nem próbált meg komolyan tanulmányozni olyan problémát, amit a hadmüvészetnél alsóbbrendünek tartott." (Trinquier [1985] 6-7. o.)

A konvencionális államközi háborúra szakosodott hadseregnek 1945 után két, intenzitásában és jellegében eltérő kihívással kellett szembenéznie. Az egyik a nukleáris háború veszélye volt, ami minimálisra csökkentette a konvencionális háború esélyét, és csupán a peremterületeken adott lehetőséget egy nagyarányú konvencionális háború megvívására. A másik kihívás az akkoriban nemzeti felszabadító háborúként, ma dekolonizációs folyamatként ismert felkelések hullámában jelentkezett.

Mások mellett Martin van Creveld is felhívta a figyelmet arra, hogy a nukleáris háború árnyékában vívott konvencionális háború dilemmájára nem sikerült megoldást 
találni a hidegháborúban. Vagyis: ha a konvencionális erő túl akarja élni a nukleáris támadást, el kell rejtőznie, ehhez meg kell szabadulnia a nehézfegyvereitől és szét kell szóródnia, így azonban képtelenné válik a konvencionális háború megvívására. ${ }^{1} \mathrm{Ha}$ azonban háborúra kerül sor, csak a konvencionális erők bevetésével kerülhető el egy esetleges nukleáris háború, egy nukleáris háborúra berendezkedett erő pedig kétséges, hogy mennyire hatékonyan képes egy konvencionális (a korszakban bevett elnevezéssel: korlátozott) háborút megvívni. (Creveld [1991] 12. o.) A megoldás a nukleáris háború lehetőségének a figyelmen kívül hagyása lett, ami a korlátozott háború fogalmának megszületését eredményezte. A mai napig a konvencionális megközelítés az elsődleges a képzésben és a fegyverzetbeszerzésben. A katonai erő a nagyhatalmaknál koncentrálódik, amelyek a hidegháború alatt jelentős számú tanácsadót és szakértőt küldtek ki konfliktusos területekre. A tisztek képzésével hatalmas export/import ágazatot hoztak létre mind Nyugaton, mind Keleten. (Creveld [1991] 1. o.)

Mindennek az eredménye az lett, hogy az államok közötti konvencionális háború veszélye a nem állami fenyegetések mögé szorult. Ezt támasztja alá a Correlates of War nevű projekt, amely a fegyveres konfliktusok gyüjtésére szakosodott. Adatai szerint 1945-2007 között összesen 38 konvencionális jellegü államközi háborúra került sor. Ezek jelentős hányada a szükebb konfliktusos régiókra esett, ahol a résztvevő felek nem rendelkeztek nukleáris fegyverekkel, és olyan határvitáik vagy egyéb nehezen megoldható vagy feloldhatatlan ellentéteik voltak, amelyek növelték az államközi összecsapások esélyét. Ilyen konfliktusgócok:

\footnotetext{
${ }^{1}$ Az USA-ban például számos kezdeményezés és elképzelés volt az ilyen irányú reformok végrehajtására, de technológiai problémák miatt ezek nagyrészt csak tervek maradtak.
} 


\section{1. táblázat Konvencionális jellegü államközi háborúk a szükebb konfliktusos régiókban 1945-2007}

\begin{tabular}{|c|c|c|c|}
\hline Térség & Konfliktuscsoport & A háború elnevezése & időtartama \\
\hline \multirow[t]{9}{*}{ Közel-Kelet } & \multirow[t]{6}{*}{ arab-izraeli háborúk } & függetlenségi háború & 1948-1949 \\
\hline & & szuezi válság & 1956 \\
\hline & & hatnapos háború & 1967 \\
\hline & & felőrlő háború & 1969-1970 \\
\hline & & Yom Kippur háború & 1973 \\
\hline & & libanoni beavatkozás & 1982 \\
\hline & \multirow{3}{*}{$\begin{array}{l}\text { Irak részvételével } \\
\text { zajló háborúk }\end{array}$} & iraki-iráni háború & 1980-1988 \\
\hline & & öbölháború & 1990-1991 \\
\hline & & Irak elleni háború & 2003 \\
\hline \multirow[t]{13}{*}{ Kelet-Ázsia } & \multirow{4}{*}{$\begin{array}{l}\text { indo-pakisztáni } \\
\text { háborúk }\end{array}$} & első kasmíri háború & 1947-1949 \\
\hline & & második kasmíri háború & 1965 \\
\hline & & bangladesi háború & 1971 \\
\hline & & Kargil háború $^{2}$ & 1999 \\
\hline & \multirow{6}{*}{$\begin{array}{l}\text { indokínai konfliktus } \\
\text { és utóélete }\end{array}$} & vietnami háború $^{3}$ & $1965-1975$ \\
\hline & & $\begin{array}{l}\text { laoszi háború második } \\
\text { szakasza }\end{array}$ & $1968-1973$ \\
\hline & & $\begin{array}{l}\text { kommunista koalíció } \\
\text { háborúja }\end{array}$ & 1970-1971 \\
\hline & & $\begin{array}{l}\text { vietnami-kambodzsai } \\
\text { határháború }\end{array}$ & 1975-1979 \\
\hline & & sino-vietnami háború & 1979 \\
\hline & & sino-vietnami határháború & 1987 \\
\hline & \multirow{3}{*}{$\begin{array}{l}\text { hidegháború forró } \\
\text { háborúi }\end{array}$} & koreai háború & 1950-1953 \\
\hline & & partmenti háború & 1954 \\
\hline & & tajvani-szoros háború & 1958 \\
\hline
\end{tabular}

(Singer és Small [2010a])

A hidegháború forró háborúi kategóriához Európából még hozzá lehet venni a szovjet beavatkozást Magyarországon (1956), vagyis a COW által nyilvántartott 1945 utáni 38 háborúból 23 besorolható öt nagyobb kategóriába és két nagyobb térségbe. Az előbbi kategóriákba be nem sorolható államközi háborúk a következők:

\footnotetext{
${ }^{2}$ A felsoroltak közül a Kargil háború jelent kivételt, mert megvívása idején mindkét ország nukleáris hatalom volt. Ugyanakkor nem voltak a határon átívelő hadmüveletek, a konfliktus egyfajta korlátozott tüzérségi és légi párbajként zajlott le.

${ }^{3}$ A szerző véleménye szerint a COW adatait itt érdemes lenne kettéválasztani: 1973-mal lezárni az amerikai szakaszt, megkülönböztetve töle egy észak- és dél-vietnami szakaszt 1973-1975 között.
} 


\section{2. táblázat A szűkebb konfliktusos régiókon kívül eső konvencionális államközi háborúk 1945-2007}

\begin{tabular}{|l|l|r|}
\hline Kontinens & A háború elnevezése & időtartama \\
\hline Afrika & ifni háború & $1957-1959$ \\
\cline { 2 - 3 } & angolai háború nemzetközi szakasza & $1975-1976$ \\
\cline { 2 - 3 } & ogadeni háború & $1977-1979$ \\
\cline { 2 - 3 } & ugandai-tanzániai háború & $1978-1979$ \\
\cline { 2 - 3 } & Aouzou sáv háború & $1986-1987$ \\
\cline { 2 - 3 } & etióp-eritreai határháború & $1998-2000$ \\
\hline Ázsia & asszami háború & 1962 \\
\cline { 2 - 3 } & afganisztáni háború & 2001 \\
\hline \multirow{5}{*}{ Dél-Amerika } & falklandi háború & 1982 \\
\cline { 2 - 3 } & Cenepa háború & 1995 \\
\cline { 2 - 3 } & futballháború & 1969 \\
\hline Európa & ciprusi háború & 1974 \\
\cline { 2 - 3 } & boszniai függetlenségi háború & 1992 \\
\cline { 2 - 3 } & azeri-örmény háború & 1999 \\
\cline { 2 - 3 } & koszovói háború & \\
\hline
\end{tabular}

Forrás: (Singer és Small [2010a])

A fentiek alapján azt mondhatjuk, hogy a konvencionális eszközökkel vívott államközi háborúk esélye (és elfogadottsága a konfliktusok megoldására) a szélesebb nemzetközi rendszerben nagymértékben lecsökkent. ${ }^{4}$ Megszünésről természetesen nincs szó, viszont jellemzően olyan területekre koncentrálódik, ahol a konfliktusnak jelentős történelmi háttere volt.

Ahogyan a táblázat is mutatja, a szuperhatalmak részéről a konvencionális erő alkalmazása ritka. Az Egyesült Államoknak a koreai (1950-1953) és iraki (1991 és 2003) részvételét lehet csak a konvencionális államközi háborúk közé sorolni (a Grenada, illetve Panama elleni invázió, bár teljesíti a kívánt kritériumokat, a mérete miatt nem került fel a COW listájára). A többi katonai erőt igénylő beavatkozás a részéről, nem számítva a béketeremtő és békefenntartó akciókat:

1. 1958: Libanon

2. 1964-1972: Vietnam

3. 1965: Dominikai Köztársaság

4. 1972-1975: Kambodzsa

${ }^{4}$ A COW listáját csupán két ponton lehet kiegészíteni a 2007 utáni időszakból: az Egyesült Államok esetében a líbiai beavatkozás, Oroszország esetében a Grúzia elleni háború sorolható ebbe a kategóriába. 
5. 1983: Libanon

6. 1999: Koszovó

Szovjet részről a konvencionális erő alkalmazása eléggé sajátos, mivel főként szövetséges országokban került rá sor: 1953-ban a Német Demokratikus Köztársaságban, 1956-ban Magyarországon, 1968-ban Csehszlovákiában és 1979-1989 között Afganisztánban. ${ }^{5}$

Míg a nukleáris vetélkedés a nemzetközi kapcsolatokban a status quo megőrzését szolgálta a kölcsönösen biztosított pusztítás doktrínájának létrejöttével, addig a felkelések (sokszor külföldi támogatással) a nemzetközi rendszerben kialakult erővonalak átrajzolásához vezettek, nem utolsósorban azért, mert katonailag dominánsnak vélt hatalmakat is feladásra kényszerítettek ezekben a konfliktusokban. ${ }^{6}$ Úgy az Egyesült Államok, mint a Szovjetunió tanácsadókkal és egyéb módon segítve számos ilyen konfliktusban vett részt, mind felkelőket támogató, mind felkelésellenes aspektusban. A közvetlen találkozás azonban egyiknek sem hozott közvetlen sikert: az Egyesült Államok Dél-Vietnamban nem volt képes politikai döntést kierőszakolni, a Szovjetunió pedig Afganisztánban nem tudott úrrá lenni a felkelés jelentette kihíváson.

A dekolonizációs időszakban a nem állami szereplők részvételével zajló fegyveres konfliktusok kevésbé látványos és intenzív, de politikailag jelentős eseményekként alakították a nemzetközi rendszert. A poszthidegháborús időszakban a gyenge államok számának növekedése adott jelentős lökést az irreguláris fegyveres csoportok müködésének. A nem állami szereplők részvételével zajlott konfliktusokból a COW adatbázis közel 170-et ${ }^{7}$ tart számon. (Singer és Small [2010b]) Bár ezek erősen lokalizált konfliktusok, az utóbbi években egyértelművé vált, hogy a gyenge és bukott államok, valamint a kormányzás nélküli területek problematikáját nem lehet elszigetelten kezelni. Az ilyen országok sokszor jó terepet jelentenek irreguláris

${ }^{5}$ Bár Afganisztán a többi felsorolt állammal ellentétben nem volt a szovjet szövetségi rendszer tagja, elhelyezkedése miatt a szovjet vezetés kiemelt szerepet és fontosságot tulajdonított neki (tartva a potenciális instabilitástól vagy ellentétes szövetségi rendszer irányába való helyezkedéstől).

${ }^{6}$ A francia távol-keleti és algériai vereség kapcsán erről bővebben lesz szó.

${ }^{7}$ A COW adatok három csoportot különböztetnek meg az államon belüli háború kategóriában: polgárháború (egy állam kormányának egy nem állami csoport elleni harca), regionális belső háború (egy regionális alegység kormányának harca egy nem állami csoport ellen) és interkommunális háború (két vagy több nem állami entitás harca egy államon belül). (Sarkees [2010] 2. o.) Az ide sorolt konfliktusok között egy regionális belső háború (a kulturális forradalom) és tizenegy interkommunális háború van, az összes többi polgárháború, ami vagy a központi hatalom megszerzéséért folyik, vagy helyi okok miatt tört ki. A COW definíciói közül a polgárháború definíciója nagyon közel áll a disszertációban alkalmazott felkelésdefinícióhoz, viszont a konfliktus egyedi elbírálására lenne szükség ahhoz, hogy az egybeesés megállapítható legyen. Azt kijelenthetjük, hogy a disszertáció szempontjából releváns konfliktusok száma a konvencionális államközi háborúk számát jelentősen meghaladja. 
szereplöknek $^{8}$ (transznacionális terroristáknak, szervezett bünözői csoportoknak, határokon át müködő felkelő csoportoknak stb.) illegális és sokszor erőszakos tevékenységek folytatására. ${ }^{9} \mathrm{Az}$ ilyen fenyegetések elhárítása miatt mára felértékelődött a nemzetközileg elfogadott katonai erő alkalmazása, a gyakorlata azonban sokszor jelentős problémákat vetett fel.

$\mathrm{Az}$ irreguláris fegyveres csoportok tevékenységét más körülmények is elősegítették. Az irreguláris szereplők számára jelentős áttörést hozott a második világháború. A nyugati világban korábban az ilyen jellegü fegyveres harc nem volt elfogadott, a nemzetközi jog is ezt tükrözte. A második világháborúban azonban mind a németek, mind a japánok elleni fellépésben fontos szerepet kaptak a külső támogatást élvező gerilla csoportok. Az $\mathrm{OSS}^{10}$ és az $\mathrm{SOE}^{11}$ mindkét hadszíntéren széleskörü és aktív támogatást nyújtott nekik.

Jogi szempontból is jelentős változásokat hozott az irreguláris fegyveres csoportoknak a huszadik század. Az 1907-es hágai konvenció korlátozott esetekben tette lehetővé szabadcsapatok, milíciák és spontán felkelések résztvevőinek, hogy a reguláris hadseregek tagjaihoz hasonló jogi védettséget élvezzenek. (Schmitt [2006] 29. o.) A második világháborúnak jelentős hatása volt az irreguláris ellenséggel szembeni fellépésre: korábban elfogadott és bevettnek számító módszerek váltak szabályellenessé. A harmadik genfi egyezmény harmadik cikkelye rögzíti a harcban részt nem vevőkkel szembeni bánásmód alapjait: megtiltja a gyilkosságot, a csonkítást, a durva bánásmódot és a kínzást, a túszejtést, az emberi méltóság megsértését és a megalapozott bírói ítélet nélküli kivégzések végrehajtását. ${ }^{12}$ (ICRC [1949a]) Az 1949-es genfi egyezmények komoly lépést tettek abba az irányba, hogy az államon belüli konfliktusokra is a nemzetközi jogi szabályok vonatkozzanak. Ezt a törekvést erősítette az 1977-es II. kiegészítő jegyzőkönyv. ${ }^{13}$ (Kardos és Lattmann [2010] 348-350. o.)

\footnotetext{
${ }^{8}$ A fogalom magyarázatát lásd a definíciók között. Itt nem állami fegyveres csoportokként érdemes őket értelmezni.

${ }^{9}$ Az utóbbi években a drogkereskedelem és a kalózkodás a legjelentősebb fenyegetés, amely gyenge és bukott államok területéröl indul ki.

${ }^{10}$ (USA) Stratégiai Szolgálatok Hivatala (Office of Strategic Services): a hírszerzés mellett a nem konvencionális hadviselés végrehajtása volt a feladata az ellenséges vonalak mögött.

${ }^{11}$ (GB) Különleges Müveleti Szolgálat (Special Operations Executive): nem konvencionális katonai feladatokat végrehajtó szervezet.

${ }^{12}$ Carl Schmitt arra is rámutat, hogy a korszakban a szabályozást a felkelő oldalt segítőnek tartották, mivel azt feltételezték, hogy a lakosság védelmének tétele az állami oldal tevékenységi lehetőségének korlátozásával segítette a nem állami oldalt. (Schmitt [2006] 32. o.)

${ }^{13}$ Kardos és Lattmann felhívja a figyelmet arra, hogy nem csak ezek a nemzetközi jogi egyezmények hatottak ebbe az irányba, de ezek voltak a legfontosabbak.
} 
A szabályozás természetesen rejt magában problémákat is. A kombattáns státuszra jogosult nem állami szereplök nemzetközi jogi definíciója például olyan szervezeti sajátosságokat feltételez, amiket a mai konfliktusokban is csak kevés csoport képes elérni vagy konzekvensen megvalósítani. A harmadik genfi egyezmény szerint a milíciák és más önkéntes csoportok tagjai akkor jogosultak hadifogoly státusra (és ezzel nemzetközi jogi elismertségre), ha:

• „egy a beosztottjaiért felelös személy irányítja öket”,

• „,rendelkeznek távolról felismerhetö megkülönböztető jelzéssel”,

- „,nyíltan viselik a fegyvereiket”,

- „a müveleteiket a háború törvényeivel és szokásaival összhangban hajtják végre”. ${ }^{14}$ (ICRC [1949b])

Egy másik problémára Carl Schmitt hívta fel a figyelmet, hogy ti. a genfi egyezményeket alapvetően az európai tapasztalatok mentén kodifikálták, ahol az irreguláris fegyveres kifejezés megszálló ellen védekező személyt jelentett. A második világháború utáni „forradalmi háborúkban” az irreguláris fegyveresek általában a Maoféle elképzelések mentén, agresszív módon az államhatalom megragadására törekedtek. (Schmitt [2006] 29. és 35. o.)

Mindenesetre a felkelők és más irreguláris fegyveresek számára biztosítva volt egy minimális nemzetközi jogi elismertség. A szuperhatalmak vetélkedésének segítségével (a nemzetközi közvéleményen keresztül) képesek voltak már a dekolonizációs érában támogatást szerezni az ügyüknek, biztosítva, hogy a felkelés ne szigetelődhessen el politikailag (és sokszor az anyagi támogatás tekintetében sem), és ne lehessen pusztán brutalitással fellépni ellene. A maoista népi háborús elképzelésrendszer pedig sok gyarmati felkelésnek adott komplex politikai-katonai stratégiát, aminek számos helyi értelmezése és alkalmazása született. Mindez egy jelentős technológiai és információs fellendüléssel esett egybe, ami a nem állami fegyveres csoportok helyzetét nagyban megkönnyítette. A trendet a Szovjetunió összeomlása után más tényezők tartották életben: az államstruktúra megrendülése a fejlődő világ egyes szegmenseiben, a megváltozott nemzetközi kapcsolatrendszer és az informatikai áttörés.

Ebbe a kontextusba illeszkedik a felkelésellenes müveletek alkalmazásának problematikája. A második világháború után két jelentős felvirágzása volt a

14 Történt kísérlet a szabályozás egyszerüsítésére, de az állami ellenállás miatt nem vált gyakorlattá. (Kardos és Lattmann [2010] 353. o.) 
felkelésellenes müveletek elméletének: a dekolonizáció időszaka és a 2001. szeptember 11-e utáni időszak. Mindkét esetben reaktív válaszról lehet beszélni erősen eltérő geopolitikai háttér és teljesen eltérő nemzetközi viszonyok mellett. Bár jelentős energiákat fordítottak a jelenségek megértésére, alapvető kérdések és elméleti problémák maradtak megválaszolatlanok, illetve lettek elhanyagolva intézményi vagy politikai érzékenységek miatt. A felkelésellenes müveletek hagyományosan a nem kedvelt katonai múveletek közé tartoznak az európai és amerikai katonai és politikai vezetés szemében, föként az elhúzódó voltuk, a bizonytalan kimenetelük és a velük járó nemzetközi bonyodalmak miatt. A politikai és intézményi ellenérzésekből fakadó korlátok és az egyedi stratégiai kontextus miatt az elmélet fejlődése sem lehet egyenletes.

A huszadik században a lakosságközpontú felkelésellenes hadviselés elmélete indult fejlődésnek a felkelések jellegére és a megváltozott nemzetközi viszonyokra reagálva. Bár a lakosságközpontú megközelítés nem aratott sikert sem politikai szinten - a jelentős költségek és a hosszú távú, mégis bizonytalan kimenetel miatt -, sem a hadseregekben azok intézményi kultúrája miatt, mégis ez az elméleti koncepció vált az utóbbi évtizedek meghatározó megközelítésévé a felkelésellenes műveletekben.

A nemzetközi kapcsolatok elmélete a motivációk, az erőegyensúly és az érdekek vizsgálatával keres magyarázatot a felkelésellenes müveletek végkimenetelére. Gil Merom mutatott rá arra, hogy milyen komoly kihívást jelentettek a realista iskola számára a huszadik századi felkelések, amelyek felrúgták a konvencionális háborúk törvényszerüségeit, és elérték, hogy katonailag domináns szereplők szenvedjenek vereséget. (Merom [2003] 7-10. o.)

Egyes szerzők az erőszak-alkalmazással kapcsolatban túlzottan leegyszerüsítő megállapításokat tettek. Arreguín-Toft például azt állítja, hogy a politikai berendezkedésnek jelentős szerepe van a konfliktusok kimenetelében, mivel a demokratikus rendszerek nem harcolnak olyan hatékonyan, mint a diktatórikusak, sőt eredendő hátrányban vannak velük szemben ezen a téren. (Arreguín-Toft [2001] 95. o.) Elsősorban a stratégiai aszimmetria kérdését vizsgálta, a konfliktusok katonai vonatkozásaira alig fordított figyelmet. Véleménye szerint a barbarizmus ${ }^{15}$ hatékonyan müködő felkelésellenes stratégia, ugyanakkor politikailag nehezen kivitelezhető. Két

\footnotetext{
${ }^{15}$ Értelmezésében a barbarizmus ,,szisztematikus megszegése a háborús törvényeknek, katonai vagy politikai stratégiai célok megvalósítása érdekében.” Ide sorolja többek között a tiltott fegyverek alkalmazását és a nem kombattánsok ellen alkalmazott erőszakot. (Arreguín-Toft [2001] 101. o.)
} 
dolgot javasolt a jövő konfliktusaival kapcsolatban: alacsonyan kell tartani a várakozásokat, és megfelelően felkészített, erre specializálódott erőket kell bevetni. (Arreguín-Toft [2001] 122-123. o.) Más szakértők ennél is radikálisabb véleményeket fogalmaztak meg: Edward Luttwak szerint egy megszálló akkor lehet sikeres a felkelökkel szemben, ha hajlandó túlterrorizálni a felkelőket, megfosztva ezzel öket a lakosság támogatásától (a német megszállás példáit hozta fel érvelése alátámasztására). Szerinte az alapvető probléma Irakban, és korábban Vietnamban is az volt, hogy az Egyesült Államok nem hajlandó kormányozni azt, amit meghódított. (Luttwak [2006] 911. o.) Mearsheimer más szempontból közelíti meg a problémát Irak példáját elemezve. Véleménye szerint az alapprobléma egy megszállt ország lakosságának nacionalizmusa, ami lehetetlenné teszi, hogy egy idegen ország domináljon. Elkerülhetetlenül kihívja maga ellen a nacionalista erőket, egyesíti magával szemben az ország közvéleményét, és egy hosszú távú konfliktusban találja magát, aminek részben ő az oka. Így, ha az Egyesült Államok bármilyen oknál fogva beavatkozik valahol, felkelés fog kialakulni. A felkelés leverése jelentős erőforrásokat kíván, emellett az aktuális katonai képességek is kevéssé alkalmasak ilyen feladatokra. (Mearsheimer [2005])

A nem realista szerzők is csak részleges válaszokat adnak a felkelés jelentette kihívásra. A motivációs elmélet szerint a nem állami szereplő motivációja erősebb, mint egy olyan államé, amelyik a saját érdekei alátámasztására avatkozik be egy konfliktusba, hiszen az állam létét nem fenyegeti a konfliktus, a nem állami szereplő számára viszont a létezése a tét. Győzelem esetén a beavatkozó állam a saját érdekei megerösítését éri el, a nem állami szereplő a kitüzött politikai célját - legyen az függetlenség, az államhatalom megszerzése vagy egyéb politikai célkitüzés. A motivációs irányzat úttörője Andrew Mack, aki röviddel a vietnami háború befejezése után fejtette ki az elméletét.

Egy másik irányzat szerint a demokratikus államok a felkelésellenes hadviselésben azért vallottak kudarcot az második világháború után, mert a demokratikus struktúrák korlátozták őket. Az ilyen jellegü konfliktusoknak áruk van (brutalitásban, veszteségben, anyagiakban), és a hajlandóság ezek megfizetésére nagymértékben csökkent. Az irányzat kiemelkedő képviselője, Gil Merom szerint a demokrácia intézményrendszere ad lehetőséget a háborúellenes csoportok érdekartikulációjára, és a helyzet látványos javulásának hiányában válik a politikai környezet idővel háborúellenessé. Az ebből adódó belpolitikai viták és problémák 
ellehetetlenítik a háború politikai támogatását, feladásra vagy legalábbis visszavonulásra kényszerítve a demokratikus államot. (Merom [2008] 229-231. o.)

A disszertáció célja, hogy bemutassa a jelenlegi lakosságközpontú felkelésellenes müveletek fejlődésének útját, rámutasson az elmélet gyengeségeire, problémáira és napjaink kihívásaira, amelyekre az elmélet a szakaszos fejlődés miatt nem volt felkészülve. A disszertáció vizsgálja az Egyesült Államok és a NATO felkelésellenes doktrínáit. Ezek váltották ki azt az elméleti vitát, amely jelentős mértékben járult hozzá az elmélet fejlödéséhez. Hatásuk az USA és a NATO szoros együttmüködési rendszerein keresztül igen jelentős a nyugati országokra és hazánkra is. A disszertáció másik fontos célja, hogy a harmadik szereplős felkelésellenes elméletet vizsgálva bemutassa, milyen politikai keretek szükségesek a felkelésellenes müveletek sikeres végrehajtásához.

A disszertációnak nem célja a diktatúrák, autoriter rendszerek és illiberális demokráciák által alkalmazott felkelésellenes hadviselési gyakorlat vizsgálata, kivéve, ha hatott a demokratikus államok elméletének történeti fejlődésére. Ennek a legfontosabb oka, hogy napjainkban a liberális demokráciákban és az előbb említett politikai berendezkedésü államokban a civil-katonai viszony olyan mértékben eltérö, hogy a taktikai összehasonlítás stratégiai szempontból értelmetlen. A polgári lakosság tömeges, kényszer alatt végrehajtott áttelepítése például taktikailag és stratégiailag végrehajtható egy diktatúrában, egy demokráciában azonban - vegyen az részt akár valamilyen idegen ország felkelésellenes küzdelmében - elfogadhatatlan. Ennek megfelelően az illiberális demokráciák belső hatalmi kapcsolatrendszere legjobb esetben is felületessé teszi az összehasonlítást (például az állam és a média viszonya, vagy a hadsereg és a politikai vezetés viszonya tekintetében). Annyira különbözhetnek, hogy a taktikailag relevánsnak tünő tanulságok teljes mértékben értelmetlenné válnak egy liberális demokrácia kontextusában. David Kilcullen így ír erről: „,(..) $a$ felkelésellenes hadviselés az államot tükrözi: bármely állam hozzáállása a felkelésellenes hadviseléshez nagymértékben függ az állam természetétöl, és a „,felkelésellenes müveletek” kifejezés teljesen más dolgot jelenthet az érintett kormány jellegétöl függöen.” (Kilcullen [2010] 10-11. o.)

A disszertáció a fentebbieknek megfelelően a történeti háttér vizsgálatánál NagyBritannia és Franciaország felkelésellenes hadviselés-történetére épül. Az elméleti háttér vizsgálatakor mindkét ország esetében röviden foglalkozunk a második 
világháború előtti időszakkal, majd részletesebben a második világháború utáni korszakkal. ${ }^{16}$

A felkelésellenes elmélet fejlődése három szakaszra bontható:

1. preklasszikus szakasz: $1896^{17}-1944$ közötti időszak

2. klasszikus szakasz: 1944-1982 ${ }^{18}$ közötti időszak (Kilcullen [2006] 1. o.)

3. neoklasszikus szakasz: 1982-től napjainkig tartó időszak

A disszertáció elméleti újdonsága a harmadik szereplős felkelésellenes hadviselés fogalmának bővítése. A mai harmadik szereplös és a kétszereplös felkelésellenes hadviselés különbségeinek és sajátosságainak vizsgálatával elméleti és gyakorlati különbségeket állapít meg a felkelésellenes elmélet klasszikus és neoklasszikus szakaszának politikai-stratégiai helyzetében. Felvázolja a felkeléselmélet és a lakosságközpontú felkelésellenes elmélet fejlődésének fö vonalait, kiemelten kezelve az aktuális kihívásokat.

A disszertáció hipotézise a következő:

- Napjaink felkelésellenes elméletének végrehajtásbeli problémáit az okozza, hogy stratégiai szinten elválasztja egymástól a politikai és a katonai dimenziót.

A disszertáció hét fejezetből áll. Az első a felkelés problematikájával foglalkozik, a második a brit, a harmadik a francia, a negyedik az amerikai felkelésellenes elmélet fejlődését mutatja be. Az ötödik napjaink felkeléseinek sajátosságait vizsgálja, a hatodik témája a harmadik szereplős felkelésellenes hadviselés, a hetedik az Egyesült Államok és a NATO felkelésellenes doktrínáit vizsgálja.

\section{Módszertan}

A felkelésellenes mủveletek vizsgálata multidiszciplináris megközelítést igényel, mivel a politikai és katonai szférák szoros integrációja szükséges ahhoz, hogy az ilyen konfliktusokat sikerrel lehessen megvívni. A történeti és elméleti részben ezért a

\footnotetext{
${ }^{16}$ A második világháborús releváns felkelésellenes hadviselési tapasztalatok a német és japán fegyveres erőknél gyültek össze - a szövetséges hatalmaknak (leszámítva a szovjeteket Ukrajnában) nem kellett ilyesfajta müveleteket végrehajtaniuk. A kezdeti amerikai felkelésellenes doktrína megfogalmazásánál még hatottak a tengelyhatalmak tapasztalatai, de a hidegháborúban gyorsan érvényüket vesztették.

${ }^{17}$ Kiindulópontnak Callwell klasszikus munkája első kiadásának dátumát jelöltük meg, amit az első jelentős felkelésellenes elméleti munkának szokás tekinteni.

${ }^{18}$ David Kilcullen felosztását követve a kiindulópont a görög polgárháború kitörésének kezdete, a végpont pedig a rhodéziai polgárháború - mint utolsó jelentős dekolonizációs konfliktus - vége.
} 
politikai szerep (azon belül is a civil-katonai kérdések a felkelésellenes hadviselés kontextusában) és a jogi kérdések (főleg az erő alkalmazásával kapcsolatban) jelentős szerepet kapnak.

A felkelésellenes elmélet fejlődését primer források (a maradandó hatású katonai doktrínák és olyan müvek, amelyek hatással voltak a hivatalos doktrínák fejlődésére), illetve szekunder források (különböző felkelésellenes müveleteket katonai vagy egyéb szempontból feldolgozó müvek) alapján vizsgáljuk. A két legfontosabb forrás a brit és a francia felkelésellenes irodalom, mert ezek adják a mai elmélet alapját.

A disszertáció első részében a brit és a francia felkelésellenes elmélet fejlődését és a kor neves szerzőinek műveit mutatjuk be a klasszikus szakasz felkeléseinek általános sajátosságairól szóló felvezetéssel. Négy szerzőt kezelünk kiemelten: Robert Thompsont, Frank Kitsont, Roger Trinquier-t és David Galula-t. Ezt követően az USA felkelésellenes elmélete, valamint doktrínáinak bemutatása következik, amit a dzsihádi felkelés elméletének jellemzőit bemutató fejezet követ, amihez két szerző - Abdelaziz Mukrin és Abu Bákr Nádzsi - munkáit használjuk fel. ${ }^{19}$ Ezután a harmadik szereplős felkelésellenes müveletekkel foglalkozunk, végül pedig a kihívásokra válaszul született két katonai doktrínát vizsgálunk, az USA FM 3-24 Felkelésellenes müveletek és a NATO AJP-3.4.4 Szövetséges összhaderönemi doktrína a felkelésellenes müveletekre című doktrínáját. Ezek adják az Egyesült Államok és a NATO-országok fegyveres erői számára a felkelésellenes hadviselés elméleti kereteit. Gyakorlati hatásuk vizsgálata túlmutat a disszertáció keretein, elsősorban a feldolgozáshoz szükséges források elérhetetlensége miatt.

A disszertáció viszonylag részletesen ismerteti a téma szempontjából megkerülhetetlen, magyarul meg nem jelent müveket. Mivel a téma Magyarországon kevéssé kutatott, magyar nyelvű szakirodalma sincs.

\section{A kutatás további lehetséges iránya és haszna}

A kutatás következő szakaszában a felkelésellenes elmélet fejlődésére gyakorolt amerikai hatásokat lesz célszerü vizsgálni. A disszertáció az amerikai példán keresztül mutatja be a katonai erő felépítésének megváltozását és a szervezeti kultúra jelentőségét. A szervezeti kultúra erős befolyással van a felkelés jelentette kihívások

\footnotetext{
${ }^{19}$ Ezek vizsgálata azért is fontos, mert angolul is megjelentek, így hatást gyakorolhattak a jelenleg érvényes doktrínák megalkotására.
} 
megválaszolására. Az USA a vietnami kudarc során tudatosan fordult el a probléma vizsgálatától, és koncentrált a konvencionális államközi konfliktusok megvívására. Ennek jegyében az erő jellege is megváltozott: egy professzionális hadsereg jött létre, amely az AirLand Battle doktrína ${ }^{20}$ megalkotásával a mozgó hadviselés szervezeti igényeit állította előtérbe. Ez a költséges platformok középpontba állítását jelentette a személyi állománylétszám kárára. Az amerikai hadsereg felszerelésbeli és képzésbeli konfigurációja 2003-ban messze volt a felkelésellenes hadviselésben történelmileg hasznosnak bizonyult összetételtől. ${ }^{21}$ A kutatás eredményei rávilágítanak az amerikai doktrína hiányosságaira és erősségeire.

A kutatási eredmények hazai szempontból is hasznosak lehetnek, mivel hazánk ilyen jellegű konfliktusokban való részvételére a jövőben is számítani lehet. Az elmélet megfelelő alkalmazásával és a disszertáció következtetéseivel a fellépés ideális esetben hatékonyabbá tehető. A felkelésellenes hadviselés elmélete a szerző véleménye szerint az afgán beavatkozás méretének csökkenésével is releváns marad, és további tanulmányozást igényel.

\section{Megjegyzések}

Az anyaggyüjtés a disszertációhoz 2012. december 31-ével került lezárásra.

Az idézett szövegek, amennyiben nem magyar nyelvü forrásból származnak, a szerző fordításai.

Az arab neveknél nem az angol nyelvű szakirodalomban alkalmazott írásmódot vettük át, hanem átírtuk a magyar kiejtés szerint.

${ }^{20}$ Az AirLand Battle (szárazföldi-légi ütközet) nem hivatalos nevet kapta az 1982-es FM 100-5 „Műveletek” doktrína, ami megfogalmazta a mély csata elképzelést, és jelentős együttmüködési lehetőséget vázolt fel a légierővel. Az AirLand Battle az amerikai hadsereg meghatározó törekvését jelentette a poszt-vietnami érában a konvencionális államközi háború irányába való elmozdulásra. Az itt megfogalmazott igényekhez igazították a technológiai fejlesztéseket is, melyek eredményeként több ma ismert amerikai fegyverrendszert állítottak rendszerbe. Ez gyakorlatilag visszarendeződést jelentett az intézményi értékrendben, és a felkelésellenes hadviselés elmélete és gyakorlata lekerült a napirendröl.

${ }^{21}$ A klasszikus és a modern szerzők is felhívják arra a figyelmet, hogy a felkelésellenes műveletek jellegüket tekintve sok emberi eröt kívánnak (különös tekintettel a specializált feladatokat ellátó állományra) és általánosságban (a speciális területektől eltekintve) alacsony technológiai színvonalat igényelnek. 


\section{Definíciók és a felkelésellenes hadviselés elméleti behatárolása}

Pontos definíciók adása ${ }^{22}$ jelentős kihívás, mert az elméletfejlődés számos olyan kifejezést és definíciót produkált, amely az évek során inkább megnehezítette, semmint megkönnyítette a tisztánlátást. Jó példa erre a felkelésellenes hadviselés fogalmának és különböző elnevezéseinek fejlődése. A forradalmi hadviselés, az alulkorlátozott hadviselés, ${ }^{23}$ a gerillaellenes hadviselés, a terrorelhárítás stb. fogalma sokszor a szakirodalomban is homályos és olykor egybemosódott.

Az alábbiakban a legfontosabb fogalmakat definiáljuk. A modern fogalommeghatározásokat alkalmazzuk, többségük az Egyesült Államok által hivatalosan használt definíció. Mellettük a hatályos NATO- definíciókat is ismertetjük, hogy egyértelmü legyen az amerikai és a NATO fogalomhasználat hasonlósága, és így egyszerübb legyen a két doktrína összehasonlítása.

\section{Aszimmetria}

A téma kapcsán talán a legtöbbször használt fogalom az aszimmetria. A hivatalos definíciók aszimmetrikus alakban definiálják az alábbi módon: „, Katonai müveletekben eltérő stratégiák, taktikák, képességek és módszerek alkalmazása azért, hogy megkerüljék vagy semlegesitsék az ellenség erösségeit, miközben kihasználják a gyengéit." (DODMAT [2013] 21. o.)

Az aszimmetria fogalma 1995-ben jelent meg először az amerikai doktrínaírásban, jelentése ekkor az eltérő erők közötti összecsapásra korlátozódott. Ezután gyors fejlődésnek indult, és hamarosan magába foglalta a terrorizmus, a tömegpusztító fegyverek alkalmazása és az információs hadviselés jelentette veszélyeket. (Metz és

\footnotetext{
${ }^{22}$ Ebben a fejezetben a jelenlegi katonai definíciókat összegyüjtve és alapul véve közlünk definíciókat. A téma szempontjából szükséges megemlíteni, hogy a politikai alapú konfliktusbeosztás, mint a polgárháború, a lázadás és más fogalmak itt nem kerülnek részletes kibontásra vagy definiálásra, mivel a disszertáció fó célja a felkelésellenes elmélet fejlődésének a vizsgálata. Formailag ettől függetlenül az irreguláris hadviselés fogalomkörébe tartozó legtöbb konfliktus politikailag besorolható polgárháborúnak, ha kiindulópontnak vesszük Kalyvas definícióját: „,Fegyveres konfliktus egy elismert szuverén entitás határain belül olyan résztvevök között, akik egy közös hatalomnak vannak alárendelve az ellenségeskedés kitörésekor.” (Kalyvas [2009] 17. o.)

${ }^{23}$ Sublimited warfare a hatvanas években volt népszerü kifejezés az Egyesült Államokban az irreguláris fenyegetésekre adott válasz leírásáraként. A kifejezés maga a korszak sajátos szóhasználatából ered, amikor a totális háború és a korlátozott (konvencionális) háború volt a két fö háborús forma. Az „alulkorlátozott” kifejezés a különbség minőségi voltát volt hivatva kifejezni. A gyakorlatban elsősorban katonai, pénzügyi és technikai segítségnyújtást jelentett szövetséges államoknak, felkelések leverésére. (Cannon [1989] 30-31. o.)
} 
Johnson [2001] 2-3. o.) Ez túl tág értelmezés ahhoz, hogy hasznosan legyen alkalmazható a felkelésellenes müveletek elemzésénél. Érdemes összevetni a Steven Metz és Douglas V. Johnson által megfogalmazott körültekintőbb definícióval, mely szerint „katonai ügyekben és nemzetbiztonsági kérdésekben az aszimmetria az ellenséghez képest eltérö cselekvés, szervezés és gondolkodás az előnyök maximális kihasználása érdekében a kezdeményezés megszerzésére, az ellenség gyengéinek kihasználására vagy nagyobb müveleti szabadság megszerzésére. Lehet politikaistratégiai, katonai-stratégiai, hadmüveleti, vagy ezek kombinációja. Tartalmazhat eltérö módszereket, technológiákat, értékeket, szervezeteket, idöperspektivát vagy ezek valamilyen kombinációját. Lehet rövid távú vagy hosszú távú. Lehet szándékos vagy alapértelmezett. Lehet önálló vagy összhangban alkalmazott szimmetrikus megközelitésekkel. Lehet pszichológiai és fizikai dimenziója.” (Metz és Johnson [2001] 5-6. o.) A szerzőpáros vezette be a pozitív és a negatív aszimmetria fogalmát. Pozitív aszimmetria alatt egy tudatosan létrehozott különbségre alapozott előnyszerzést értenek, negatív aszimmetria alatt az ellenség gyengeségeinek kihasználását. (Metz és Johnson [2001] 6. o.) Az aszimmetria fogalmát ezért érdemes árnyalni aszerint, hogy milyen (technológiai, taktikai, szervezeti, időbeli, stratégiai stb.) megközelítést alkalmazunk. A felkelésellenes hadviselés szempontjából az aszimmetria kérdése olyan szempontból fontos, hogy segít leírni a felkelő és a felkelésellenes oldal stratégiai, müveleti és taktikai különbségeit.

\section{Irreguláris hadviselés}

Az alkalmazott fogalmi keretek az elmúlt években jelentős fejlődésen mentek át, különösen igaz ez az irreguláris hadviselésre. Az irreguláris hadviselés a korszerü kihívások legátfogóbb definíciós keretét adja, magába foglalva a nem állami szereplők ${ }^{24}$ jelentette kihívásokat (vagyis a felkelést is). A változás mértékét jól jelzi, hogy sem az 1995-ös Nem háborús katonai müveletek összhaderőnemi doktrínája (Joint Publication 3-07 Joint Doctrine for Military Operations Other Than War), sem az 1997-es amerikai Összhaderőnemi Doktrína Enciklopédia (Joint Doctrine Encyclopedia) nem ismeri. A

${ }^{24}$ „Nem állami szereplök, beleértve személyeket, eröszakos szélsőséges csoportokat és államszerü ellenségeket, amelyek használhatnak konvencionális és irreguláris módszereket. Az államjellegü ellenségek olyan nem tradicionális ellenségek, amelyek olyan szintre fejlödtek, hogy államjellegü hatalommal, tekintéllyel és befolyással rendelkeznek a lakosság felett. Ezek olyan elemek, amelyek egy lakossági csoportból erednek és de facto kormányzattá nötték ki magukat, de nincsenek elismerve az Egyesült Államok és a nemzetközi közösség által.” (IW JOC2 [2010] 8. o.) 
2006-os Négyéves Védelmi Felülvizsgálat (Quadrennial Defense Review, QDR) címü kiadványban jelent meg először ${ }^{25}$ a hivatalos fogalomhasználatban. ${ }^{26}$ (QDR [2006] 3. o.) Ezt követően több kiadvány is foglalkozott a fogalom definiálásával, ennek eredményeként született meg az Irreguláris hadviselés: Az irreguláris fenyegetések elhárítása (Irregular Warfare: Countering Irregular Threats) címü kötet, továbbá bekerült az új doktrínális iratokba, többek között az FM 3-24 Felkelésellenes müveletek ${ }^{27}$ is alkalmazza a felkelésellenes müveletek fogalmi elhelyezésére. (FM 3-24 [2006] 1-1. o.)

A fogalom számos definíciója látott napvilágot:

1. A 2005-ös Nemzeti Védelmi Stratégia (USA) szerint: „Irreguláris kihívást jelentenek azok, akik „,nem konvencionális” módszereket alkalmaznak, hogy az erösebb ellenfelek ,,tradicionális” elönyeit semlegesitsék.” (NDS [2005] 2. o.)

2. A 2006-os Négyéves védelmi felülvizsgálat (USA) szerint ezek ,olyan konfliktusok, ahol az ellenséges kombattánsok nem egy nemzetállam reguláris katonai erejének tagjai” (QDR [2006] 3. o.)

3. Az Összhaderőnemi Müveleti Koncepció (USA) szerint az „alkalmazkodó ellenségek, mint a terroristák, felkelök és bünözői hálózatok, ahogyan az államok is, egyre inkább a hadviselés irreguláris formáihoz fognak nyúlni, mint a konvencionális hatalmak hatékony kihívásának eszközéhez. A technológiai fejlödés és más trendek a környezetben ezeket az irreguláris kihívásokat egyre halálosabbá fogják tenni, széleskörü káosz okozására alkalmassá fognak válni és más módon is nehezen lehet majd ellenük fellépni. Ezek a veszélyek behálózzák a lakosságot, és a fejlődő kommunikáció, kibertér, technológia egyre nagyobb kapacitást tesz elérhetövé számukra, olyannyira, hogy a hatásuk kiterjed a régióra vagy globális lehet. Az ilyen konfliktusok között sok a befolyásért és legitimitásért vívott párharc egy releváns populáció felett." (IW JOC2 [2010] 4. o.)

4. Az USA védelmi minisztérium Katonai és vonatkozó kifejezések szótára szerint „fegyveres harc állami és nem állami szereplök között a legitimitás és befolyás

\footnotetext{
${ }^{25}$ Nem összetévesztendő a hosszú háború koncepcióval, ami szintén ebben a jelentésben szerepelt.

${ }^{26}$ Fontos hozzátenni, hogy nem ez volt az első alkalom. A 2005-ben kiadott Nemzeti Katonai Stratégia már használta a fogalmat, a QDR-ban feltehetően ennek hatására szerepel.

${ }^{27}$ A hivatalos megnevezése a doktrínának FM 3-24/MCWP 3-33.5 vagyis 3-24 Kézikönyv és 3-33.5 Tengerészgyalogsági Hadviselési Publikáció, ami annak a jele, hogy a két haderőnem közös munkájának eredménye a publikáció; az egyszerüség kedvéért és az elterjedtsége miatt FM 3-24-ként fogunk rá hivatkozni a későbbiekben.
} 
megszerzése érdekében releváns populáció(k) felett.” (DODMAT [2013] 137. o.) Az irreguláris erők pedig ,,fegyveres személyek vagy csoportok, akik/amelyek nem tagjai vagy részei a fegyveres erőknek, a rendörségnek vagy más belbiztonsági erőnek”. (DODMAT [2013] 137. o.)

A NATO-definíció szerint az irreguláris tevékenység: „Erő alkalmazása vagy azzal való fenyegetés irreguláris erök, csoportok vagy egyének által, sokszor ideológiai vagy bünelkövetési motivációval, azzal a céllal, hogy változást csikarjanak ki vagy akadályozzanak meg, kihívást intézve a fennálló kormányzattal és legitim hatalommal szemben." (AAP-6 [2013] 2-I-9. o.) Megjegyzendő, hogy a NATO által alkalmazott definíciós keretek egy fontos dologban eltérnek az amerikaitól: a NATO az irreguláris tevékenység fogalmát nem kizárólag katonai értelemben használja. Az AJP-3.4.4 ugyanis a reguláris tevékenységek közé a diplomáciát, a politikát, a szociális ügyeket, a gazdaságot és a vallást sorolja, vagyis alapvetően politikailag értelmezi a fogalmat, nem katonai szempont szerint. (AJP-3.4.4 [2011] 3-2. o.)

Mint látható, a 2005-ös definícióhoz képest jelentős elméleti fejlödés ment végbe. Az aktuális definíciók a taktika mellett figyelmet fordítanak a résztvevő erő jellegére (nem állami és állami), a párharc lehetséges céljára (nem állami szereplő esetében a lakossági támogatáson keresztüli politikai befolyás), figyelembe veszik a megváltozott technológiai körülményeket és előtérbe helyezik az ellenség ideológiai motivációját. A definíciós elemek azt is jól mutatják, hogy a felkelésellenes hadviselésben szerzett tapasztalatok nagymértékben alakították az irreguláris hadviselés fogalomkörének fejlődését.

A fentieknek alapján az irreguláris hadviselés ideológiai alapon motivált nem állami szereplők által, nem konvencionális stratégiával (erőszakkal vagy azzal való fenyegetéssel) törekszik az államhatalom megszerzésére, valamilyen állami politika módosítására vagy valamilyen politikai változás megakadályozására.

Az irreguláris hadviselés fogalomkörébe tartozik három kihívás, amit a fogalmi lehatárolás érdekében az alábbiakban alaposabban körül fogunk járni. Ezek: az ellenállás, a terrorizmus és a felkelés.

Az ellenállás fogalmát az amerikai védelmi minisztérium „ellenállási mozgalom”ként az alábbi módon definiálja: „Az államnépesség egy rétegének szervezett kísérlete arra, hogy ellenálljon a törvényes kormányzat akaratának vagy egy megszálló hatalom intézkedéseinek, és megzavarja a társadalmi rendet és stabilitást." (DODMAT [2013]. 227. o.) Az ellenállási csoportok, mozgalmak fontos sajátossága, hogy alapvetően nem a 
hatalomátvételre irányul a tevékenységük, hanem folyamatban lévő politikákkal szemben kívánnak fellépni, akár erőszakos úton is (de nem feltétlenül, van számos példa békés eszközökkel fellépő ellenállási csoportokra is). Szervezettségük is sok esetben elmarad a felkelő vagy terrorista csoportokétól. Ennek megfelelően kijelenthetjük, hogy itt egy önálló fogalmi kategóriáról beszélhetünk, és a felkelő csoportokat nem szerencsés ellenálló csoportoknak kategorizálni, mivel céljaik alapvetően hibás értékelése történnék ezáltal.

A terrorizmus fogalmának definiálása közismerten nagy nehézségekbe ütközik. ${ }^{28}$ $\mathrm{Az}$ amerikai védelmi minisztérium hivatalos definíciója szerint a terrorizmus „,örvénytelen eröszak alkalmazása vagy törvénytelen eröszak alkalmazásával való fenyegetés használata félelem keltésére és kormányok és társadalmak kényszer alá helyezésére. A terrorizmust sokszor vallási, politikai vagy egyéb ideológiai nézetek motiválják, és általában politikai természetü célok megvalósitásáért alkalmazzák." (DODMAT [2013]. 266. o.) A NATO hatályos definíciója szerint: „Az eröszak vagy kényszer törvénytelen alkalmazása vagy azzal való fenyegetés személyek vagy tulajdon ellen azzal a céllal, hogy kényszeritsék, megfélemlitsék a kormányt vagy társadalmat azért, hogy politikai, vallási vagy ideológiai célokat valósítsanak meg." (AAP-6 [2013] 2-T-5. о.)

A két definíció valamelyest elfedi azt, hogy a terrorizmus esetünkben kettős jelentéssel bírhat: alkalmazható stratégiai és taktikai kontextusban is. A felkelésellenes müveletek aspektusából nézve a kérdést, alapvetően a taktikai kontextust kell vizsgálni, mivel a civilek ellen alkalmazott erőszak általában csak egyik része a felkelők stratégiájának - rajta kívül az állami szervek ellen irányuló erőszak, a politikai befolyásolás és propaganda, valamint a lakosság feletti irányítás megszerzése jelenti a fö csapásirányt.

\footnotetext{
${ }^{28}$ A felkelésellenes hadviselés szempontjából bonyolítja a helyzetet az is, hogy jeles szerzők eltérően viszonyulnak a kérdéshez. Marighella például az alábbi definíciót adja: ,, olyan tevékenység, amely általában nagy erejü robbanószerkezet vagy gyújtóbombák alkalmazását jelenti, amelyek képesek pótolhatatlan veszteséget okozni az ellenségnek. Nem különbözik más gerilla tevékenységtöl. A terrorizmus olyan fegyver, amit a forradalmár soha nem tehet le." (Marighella [2002] 30. o.) Che Guevara szerint azonban ,,világosan meg kell különböztetnünk a szabotázst, a hadviselés forradalmi és igen hatékony módszerét a terrorizmustól, amely általában hatástalan és eredményeiben nem válogat, minthogy gyakran ártatlan emberek az áldozatai, és sok olyan életet pusztít el, amely értékes lehetne a forradalom számára. A terrorizmust akkor tekintjük értékes taktikának, amikor arra használják, hogy kivégezzék az elnyomó erők valamely kegyetlen vagy más okból nevezetes vezetőjét, akinek elpusztitása valamiképpen hasznos. De jelentéktelen személyek legyilkolása sosem tanácsos, minthogy a megtorlások fokozódásához és elkerülhetetlen halálesetekhez vezet." (Che Guevara [2007] 53. o.) Az eltérő vélemények jól mutatják, hogy a terrorizmus alkalmazása körüli kérdések még a klasszikus szerzők körében is problémát jelentenek.
} 
A felkelés ${ }^{29}$ definíciója a fentiekhez képest is sok problémába ütközik.

1. Az amerikai védelmi minisztérium Katonai és vonatkozó kifejezések szótára szerint „szubverzióo és eröszak szervezett alkalmazása egy csoport vagy mozgalom által azzal a céllal, hogy megdöntsék vagy megváltoztassák a hatalmon lévö kormányt”. (DODMAT [2013]. 130. o.)

2. NATO: „Szervezett, sokszor ideológiailag motivált csoport vagy mozgalom akciója, aminek célja változás kieröszakolása vagy megakadályozása, vagy a kormányzó hatalom megdöntése egy országon vagy régión belül, a lakosság meggyözésére vagy megfélemlitésére koncentrálva, erőszak és szubverzió alkalmazásával. ” (AAP-6 [2013] 2-I-5. o.)

A fenti definíciókat érdemes összevetni Bard O’Neill definíciójával, aki szerint a felkelés „egy uralkodó és egy (vagy több) hatalmat átvenni kívánó csoport közötti vetélkedés a hatalomért, amelyben a hatalmat átvenni kivánó szereplök politikai eszközöket (támogatók megszervezése, propaganda, tüntetések szervezése) és eröszakot használnak arra, hogy aláássák, átformálják vagy fenntartsák az uralkodó politikai irányvonal egy vagy több aspektusát." (O’Neill [2005] 15. o.) Ez a definíció az Egyesült Államok és a NATO definícióihoz képest annyi újdonságot nyújt, hogy rámutat az ilyen konfliktusok egy gyakori sajátosságára, arra, hogy a felkelések manapság nem egy felkelő csoport vezetésével zajlanak, hanem egy töredezett, sok csoportból álló egységet képeznek, amely a történelem korábbi időszakaival ellentétben nemzetközi színtéren is képes megjelenni.

A gerilla ${ }^{31}$ fogalma a történelemben sok esetben összefonódott a felkeléssel. Fontos kijelenteni, hogy a felkelés és a gerilla hadviselés nem rokon értelmü kifejezések, hanem egymástól eltérő, sajátos hadviselési módot jelentenek. Ma a gerilla hadviselés hivatalos amerikai definíciója a következő: „, Katonai és félkatonai müveletek alkalmazása az ellenség által irányított vagy az ellenség által dominált területen, amit irreguláris, döntően helyi erők hajtanak végre.” (DODMAT [2013]. 113. o.)

\footnotetext{
${ }^{29}$ Maga a felkelés fogalma is történelmi távlatokban és országonként jelentős eltéréseket mutat (lásd például a brit és a francia elmélet fejlödése közötti különbségeket), az elnevezésekről nem is beszélve.

${ }^{30}$ Tevékenység, melynek célja, hogy aláássa a kormányzó hatalom katonai, gazdasági, pszichológiai vagy politikai erejét vagy morálját. Részletesebben lásd a következő fejezetben.

${ }^{31}$ Nincs NATO-definíciója. Gerillaellenes hadviselés: hadsereg, félkatonai és nem katonai szervezetek műveletei és tevékenysége gerillák ellen. (AAP-6 [2013] 2-C-16. o.)
} 
Az irreguláris kihívások felértékelődését a doktrínális megközelítésben mi sem jelzi jobban, hogy az FM 3-0 Mủveletek kézikönyv a fenyegetések négy jelentős csoportja közé sorolja az irreguláris fenyegetéseket:

1. konvencionális fenyegetések: „tradicionális fenyegetések, amelyek államokból indulnak ki katonai képességek és erök alkalmazásával, jól ismert katonai vetélkedés és konfliktus formájában."

2. irreguláris fenyegetések

3. katasztrofális fenyegetések: „,vegyi, biológiai, radiológiai és nukleáris fegyverek beszerzését és birtoklását jelentik"

4. bomlasztó fenyegetések: „Az ellenség új technológiák alkalmazásával csökkenti az Egyesült Államok elönyeit a fontos müveleti területeken. (...) A bomlasztó fenyegetések olyan módszereket és technológiákat alkalmaznak, amelyek a célpont számára a fenyegetés természetét illetöen érthetetlenek." Ilyenek pl. a kibermüveletek. (FM 3-0 [2008] 1-4. o.)

A jövendö kihívások terén az FM 3-0 bevezette a hibrid fenyegetések fogalomkörét, az irreguláris kihívások rendszerébe illesztve. A definíció szerint a hibrid fenyegetések „,színes és dinamikus kombinációi a reguláris és irreguláris erőknek, bünözői csoportoknak, vagy ezen erök és csoportok kombinációjának kölcsönös elönyök eléréséért. A hibrid fenyegetések kombinálják a reguláris erőket - amelyek tevékenységét a nemzetközi jog, a katonai tradiciók és szokások szabályozzák - a szabályozatlan irreguláris erökkel, amelyek nem fogadnak el semmilyen korlátot a célpontjaik ellen irányuló eröszak alkalmazásában. Ezek az erök lehetnek milíciák, terroristák, gerillák és bünözők. Az ilyen erők összeadják a képességeiket és váltogatják a reguláris és irreguláris taktikákat és fegyvereket. Ezek a képességek lehetövé teszik a hibrid fenyegetések számára, hogy kihasználják a feltételezett sebezhetöségeket, nagymértékben növelve a hatékonyságot." (FM 3-0 [2008] 1-5. o.)

Definíciós nehézségre vall a komplex müveletek fogalmának megjelenése is. Ez az amerikai kongresszus által létrehozott fogalom, amely a hadsereg által irreguláris hadviselésként definiált területet fedi le úgy, hogy a civil dimenziót, beleértve a kormányzati és nem kormányzati szerveket is, maximálisan be lehessen vonni a katonai müveletekbe. A fogalom létrehozása arra lett alapozva, hogy a hadsereg által definiált keretek között a civil szervezetek nem szívesen müködnek együtt. A komplex művelet definíciója a következő: „Tengerentúli stabilizációs müvelet, biztonsági müvelet, tranziciós és újjáépitési müvelet, felkelésellenes müvelet, vagy egy katonai és civil 
eröket egyaránt bevonó irreguláris hadviselés jellemezte müvelet." (CCO Lexikon [2011] 34. o.)

$\mathrm{Az}$ irreguláris kihívásokon belül manapság öt müveleti lehetőséget szokás megkülönböztetni. Ezek:

- terrorizmuselleni müveleti intézkedések,

- nem konvencionális hadviselés,

- külföldi belbiztonsági műveletek,

- stabilizációs müveletek,

- felkelésellenes müveletek.

A terrorizmussal szemben hozott műveleti intézkedéseknek két csoportjáról beszélhetünk: terrorizmusellenes (anti-terrorism) és terrorelhárító (counterterrorism) müveletekröl.

A terrorizmusellenes múveletek alapvetően védelmi jellegü intézkedések, amelyek támadások megakadályozására szolgálnak. Az Egyesült Államok védelmi minisztériumának definíciója szerint „defenziv intézkedések, amelyekkel személyek és tulajdonok terrorfenyegetettségét csökkentik, beleértve a gyors elszigetelést helyi katonai és civil erők által.” (DODMAT [2013] 16. o.) A NATO definíciója szerint terrorizmusellenes müvelet „,minden defenziv és preventiv intézkedés, amit azzal a céllal hoztak, hogy katonai erők, személyek és tulajdonok terrorfenyegetettségét csökkentsék." (AAP-6 [2013] 2-A-17. о.)

A terrorelhárító műveletek az offenzív intézkedéseket tömörítik. Az Egyesült Államok védelmi minisztériumának definíciója szerint ,közvetlenül a terrorista hálózatok ellen végrehajtott lépések és a globális és regionális környezet közvetett módon való befolyásolása a terrorista hálózatok kiszoritására” (DODMAT [2013] 60. o.), a NATO szerint ,minden offenziv intézkedés, aminek a célja terroristák semlegesitése, mielött és miután ellenséges cselekményeket hajtottak végre." (AAP-6 [2013] 2-C-17. o.)

A terrorelhárító müveletek kérdéskörével ezen a ponton azért érdemes külön is foglalkozni, mert a felkelésellenes müveletek keretrendszerében is gyakran beszélnek ilyen müveletekről. Olyan offenzív müveleteket neveznek így, melyek célja a politikai céljaik alátámasztására terrorizmust mint taktikát alkalmazó felkelő csoportok elleni fellépés. A felkelésellenes müveletek keretében végrehajtott ilyen jellegü müveleteknek azonban illeszkedniük kell egy szélesebb stratégiai kontextusba, míg a terrorelhárító 
műveletek tervezésénél és végrehajtásánál normál esetben nem kell figyelembe venni politikai, gazdasági és társadalmi meggondolásokat. Ezért felkelésellenes müveletek esetében az ilyen müveleteket offenzív vagy ellenségközpontú felkelésellenes müveleteknek fogjuk nevezni.

A nem konvencionális hadviselés fogalmát azért érdemes külön megemlíteni, mivel felkelésekkel kapcsolatos, de alapvetően nem felkelésellenes tevékenységet fed. $\mathrm{Az}$ Egyesült Államok védelmi minisztériumának definíciója szerint a nem konvencionális müveletek ,olyan tevékenységek, melyek lehetővé teszik az ellenállási mozgalmaknak vagy felkeléseknek, hogy kényszer alá helyezzék, szétzilálják vagy megdöntsék a kormányt vagy a megszálló hatalom uralmát földalatti csoportok, segéderők és gerilla egységek megsegitésével, vagy ezeken keresztül való müködéssel, ellenséges területen.” (DODMAT [2013] 275. o.) Ez a definíció nagymértékben összecseng a NATO-ban alkalmazottal, mely szerint: „,katonai tevékenység, földalatti csoportok, segéderök vagy gerilla egységek megsegitésére vagy segítségével végrehajtott akciók, melyek célja, hogy az ellenállási mozgalmat vagy felkelést abban segitsék, hogy kényszer alá helyezze, szétzilálja vagy megdöntse a kormányt vagy a megszálló hatalom uralmát." (AAP-6 [2013] 2-U-1. o.) Ez természetesen nem jelenti azt, hogy felkelésellenes hadviselés keretében nem kerülhet sor nem konvencionális hadviselésre, de a második világháború utáni időszakban olyan speciális esetekre szorítkozik az alkalmazása, amikor szomszédos állam területéről indítanak műveleteket a felkelők (a legjobb példa erre a franciák indokínai fellépése, amiről bővebben a francia felkelésellenes hadviselésről szóló fejezetben lesz szó).

A külföldi belbiztonsági müveletek ${ }^{32}$ hivatalos definíciója: „Egy kormányzat civil vagy katonai ügynökségeinek részvétele egy másik kormányzat vagy szervezet által létrehozott akcióprogramban, melynek célja, hogy társadalmának szabadságát biztositsa és védelmezze a szubverzióval, a törvényes rend felbomlásával, a felkeléssel, a terrorizmussal és más biztonsági kihívásokkal szemben." (JP 3-22 [2010] ix. o.) A külföldi belbiztonsági müveleteket sokszor könnyített felkelésellenes müveletnek értelmezik, ez azonban félrevezető, mivel az ilyen műveletek a különleges erők feladatkörébe tartoznak, szigorúan támogató jellegüek (eszközben, felkészítésben és egyéb felmerülő kapacitásokban), és a kiküldött tanácsadók létszámát tekintve (a felkelésellenes műveletekhez képest) kicsik. A külföldi belbiztonsági műveletek

\footnotetext{
${ }^{32}$ Az eredeti fogalom, a Foreign Internal Defense (FID) nehezen adható vissza magyarul, ezért a szerző értelmező fordítással kívánja a fogalmat átültetni a nyelvhasználatba.
} 
azonban részét képezhetik egy hosszú távú felkelésellenes stratégiának, amikor a vendéglátó állam nem szorul közvetlen katonai támogatásra a felkelők elleni harcban. (NATO-definíciója jellegénél fogva nincsen.)

A stabilizációs múveletek ${ }^{33}$ fontosságát az elméleti keretben nehéz túlhangsúlyozni. A hivatalos amerikai definíció szerint: „Számos katonai küldetést, feladatot és aktivitást jelent az Egyesült Államok határain kivül végrehajtva, koordináltan alkalmazva a nemzeti hatalom más eszközeivel együtt annak érdekében, hogy fenntartsanak vagy létrehozzanak egy biztonságos környezetet, ahol alapvetö kormányzati szolgáltatásokat, sürgösségi infrastruktúra-újjáépitést és humanitárius segítségnyújtást biztositsanak." (DODMAT [2013] 247. o.) A stabilizációs műveletek és a felkelésellenes műveletek határai sokszor elmosódnak, mivel a két feladatot szoros koordinációban kell végrehajtani. Az amerikai védelmi minisztérium 3000.05 számú utasítása az alábbi tevékenységeket sorolja a stabilizációs müveletekhez: polgári biztonság és irányítás kialakítása, az alapvető szolgáltatások helyreállítása, a kritikus infrastruktúra helyreállítása, humanitárius segítségnyújtás, a hadviselő felek lefegyverzése, demobilizálása és reintegrálása a társadalomba, a törvényes rend és kormányzás elősegítése, valamint a gazdasági stabilitás és növekedés elősegítése. (DoDD 3000.05 [2009] 2-3. o.) A stabilizációs müveletek számos olyan tevékenységet magukban foglalnak, amelyek a felkelésellenes müveletekben is jelentős szerepet kapnak a lakosságközpontú megközelítésben.

A felkelésellenes múveletek fogalmának leírására ${ }^{34}$ számos definíció létezik. Az 1986-os FM 90-8 Gerillaellenes kézikönyv szerint „a felkelésellenes küldetésbe beletartozik a kormány által alkalmazott eljárások teljes sora, aminek a célja a társadalom megszabaditása és védelme a szubverziótól, a törvénytelenségtöl és a felkeléstöl. Olyan lépésekröl van szó, melyeket egy nemzet azzal a céllal tesz, hogy segitse a növekedést megfelelö (politikai, katonai, gazdasági, szociális) intézmények létrehozásával, amelyek reagálnak a lakosság igényeire. Három célcsoportja van a kormányzati tevékenységnek: a lakosság, a felkelök és a külsö szereplök.” (FM 90-8 [1986]).

A jelenleg hivatalosan alkalmazott definíciók ennél tömörebben fogalmaznak:

\footnotetext{
${ }^{33}$ Nincs NATO-definíció.

${ }^{34}$ A klasszikus időszak szerzői által alkotott definíciók boncolgatására sor fog kerülni az egyes szerzők munkáinak értékelése során, itt az utóbbi években elterjedt definíciókat ismertetjük.
} 
- FM 3-24 Felkelésellenes műveletek: „A kormányzat által kezdeményezett katonai, félkatonai, politikai, gazdasági, pszichológiai és polgári tevékenységek, melyek célja a felkelés legyözése." (FM 3-24 [2006] 1-1. o.) ${ }^{35}$

- NATO: „Átfogó civil és katonai erőfeszitések a felkelés legyőzésére és okainak orvoslására." (AAP-6 [2013] 2-C-16. o.) ${ }^{36}$

A felkelésellenes müveletekhez kapcsolódó fontos fogalmak:

1. Hírszerzés: A felkelésellenes müvelet keretén belül az ellenséggel, ellenséges csoporttal vagy csoportokkal szembeni nyílt és titkos információgyüjtési eljárások és módszerek összessége, a megszerzett információk értékelése és értelmezése.

2. Kormányzás: Az állam képessége, hogy a lakosságot szolgálja szabályok, folyamatok és olyan viselkedés által, amivel lehetővé válik érdekek artikulálása, erőforrások menedzsmentje és a hatalom gyakorlása a társadalomban, beleértve a reprezentatív és részvételi döntéshozatali folyamatokat, amelyeket garantál egy befogadó, alkotmányos hatalom. (DODMAT [2013] 112. o.)

3. Lakosság: egy adott területen élő politikai közösség.

4. Legitimáció: „Annak a foka, amennyire a lakosság elfogadja és támogatja az adott küldetést, mandátumát és alakulását; annak a foka, amennyire a befogadó ország lakossága elfogadja és támogatja a saját kormányát (beleértve az informális kormányzati struktúrákat is); annak a módja, ahogyan a kormányzat megszerzi a hatalmat; és annak a mértéke, amennyire a regionális szomszédok és a nemzetközi közösség elfogadják a küldetés mandátumát, cselekményeit és a befogadó ország kormányát."

5. Szubverzió: „Tevékenység, melynek célja, hogy aláássa a kormányzó hatalom katonai, gazdasági, pszichológiai vagy politikai erejét vagy morálját." (DODMAT [2013] 252. o.)

6. Vendéglátó ország: ${ }^{37}$ Olyan ország, amely ,eröket és/vagy felszerelést fogad szövetséges országoktól és/vagy NATO szervezetektöl, amelyek a területén, a területéről vagy a területén keresztül müködnek”. (DODMAT [2013] 120. o.)

${ }^{35}$ Az FM 90-8 definíciójához hasonlóan az FM 3-24 is beemeli a kormányzati tevékenységet a fogalomba: „A felkelésellenes müveletek elsödleges célja a hatékony irányítás megvalósitása egy legitim kormány által." (FM 3-24 [2006] 1-21. o.)

${ }^{36}$ Az AJP-3.4.4 NATO kézikönyv tesz javaslatot egy alternatív definícióra: „Politikai, gazdasági, szociális, katonai, bünüldözési, polgári és pszichológiai tevékenységek, melyek célja a felkelés legyőzése és alapvető indokainak kezelése."(AJP-3.4.4 [2011] Lexicon - 3) 
A felkelésellenes hadviselésnek két főbb megközelítése ismert, a lakosságközpontú és az ellenségközpontú. Az utóbbi években a francia és a brit lakosságközpontú hagyományok előtérbe helyeződése miatt az elöbbi vált hangsúlyosabbá. Sajnos, a szakirodalom nem ad pontos definíciókat, ezért mi vagyunk kénytelenek definiálni őket.

- Lakosságközpontú felkelésellenes megközelítés: A lakosság védelme a felkelőktől. A felkelő csoportok elleni fegyveres fellépés csak másodlagos fontosságú, a lakosság együttmüködésének biztosítása az elsődleges. Ide sorolható a fejlesztés és újjáépítés előtérbe helyezése, a politikai legitimáció kiépítése, a lakossági biztonság megteremtése stb. Gyarmati időkből a lakosság áttelepítését is ehhez a megközelítéshez lehet sorolni. Napjainkban még a rendészeti megközelítés, a stratégiai kommunikáció és a kulturális érzékenység fontosságának előtérbe helyezése sorolható ide.

- Ellenségközpontú felkelésellenes megközelítés: A felkelő csoportok elleni fegyveres fellépés a fö erőfeszítés. Ide sorolhatók a felkelő szervezet vezetésének lefejezési kísérletei, határörizet a beszivárgás megakadályozására, amnesztia stb. Gyarmati időkből ide sorolható a kollektív felelősség és kollektív büntetés intézménye. Napjainkban a hálózatellenes müveletek ${ }^{38}$ fogalomköre tartozik ide.

Fontos megjegyezni, hogy ezek a megközelítések nem egymást kizáróak, a siker eléréséhez egyfajta egyensúlyt szükséges kialakítani a két megközelítés között.

Fontos elhatárolni a nemzetépítés és a felkelésellenes hadviselés fogalmát. Az utóbbi években a két fogalom sokszor egybemosódott. A RAND definíciója szerint a nemzetépítés „fegyveres erők alkalmazását jelenti egy szélesebb erőfeszités részeként, melynek célja politikai és gazdasági reformok végrehajtása egy konfliktus utáni társadalomban, hogy az belül és a szomszédokkal való viszonyában is békéssé váljon." (Dobbins et al [2007] xvii. o.) Ennek megfelelően a felkelésellenes műveletek fogalomkörénél jóval szélesebb fogalmi és tevékenységi keretről van szó (amiben szükség esetén sor kerülhet felkelésellenes müveletekre). A felkelésellenes müveletek

${ }^{37}$ Az eredetiben a ,nation”, vagyis nemzet kifejezés szerepel, de a szerző célszerűbbnek látta országra változtatni a kifejezést a nemzet kifejezésben rejlö politikai problémák miatt.

${ }^{38}$ Halálos és nem halálos akciók és müveletek hálózatok ellen, melyeket folyamatosan és egyidejüleg folytatnak több szinten (taktikai, müveleti, stratégiai), hogy kihasználjanak vagy teremtsenek kulcsfontosságú sebezhető pontokat és megzavarják az ellenség tevékenységét, megszüntessék a müködési képességét azért, hogy a müvelet vagy hadjárat sikere biztosítható legyen. (DODMAT [2013] 21. o.) 
során végrehajtott korlátozott kapacitás- és intézményépítési tevékenység a szerző véleménye szerint nem tekinthető nemzetépítésnek. ${ }^{39}$

\section{Felkelésellenes doktrínák}

A disszertációban az amerikai hadsereg és a NATO hivatalos felkelésellenes doktrínái is vizsgálat alá fognak kerülni. A doktrína definíciói:

USA: „A hadsereg doktrínája azon elképzelések összessége, amelyek szerint a hadsereg müködik az összhaderőnemi erő szerves részeként. A doktrína arra fókuszál, hogy miként kell gondolkodni-nem arra, hogy mit. Az alábbi elveket fekteti le:

1. a hadsereg miként tekint a müveletek természetére,

2. alapelvek, amelyek mentén a hadsereg eröi müveleteket hajtanak végre,

3. módszerek, amelyek mentén a parancsnokok gyakorolják a vezetést és az irányitást." 40 (FM 3-0 [2008] D-1. o.)

NATO: „Alapvetö alapelvek, melyek a fegyveres eröt vezérlik az akcióiban a kitüzött célok elérésére. Mérvadó, de alkalmazása itélöképességet igényel." (AAP-6 [2013] 2-D-9. o.)

\section{Dzsihádi mozgalom}

A dzsihádi mozgalom definiálására Brynjar Lia definícióját fogjuk alkalmazni, amely szerint a mozgalmat ,,szervezetek, csoportok, közösségek, tudósok, értelmiségiek, szimbolikus szereplők és egyének alkotják, akik a fegyveres dzsihád ideológiáját magukévá tették az arab-iszlám világban fennálló rezsimek ellen annak alapján, hogy ezek hitehagyott rezsimek, amelyek nem Allah szava szerint kormányoznak, (...) Allah nélkül törvénykeznek és az Iszlám Nemzet számos hitetlen ellenségének fogadnak hüséget és nyújtsanak támogatást. A dzsihádi áramlat a fegyveres dzsihád programját alkalmazza a gyarmatositó erökkel szemben, amelyek muszlim földeket támadnak meg amiatt, hogy azok az iszlám és a muszlimok szövetségesei.” (Lia [2010] 103. o.) A

\footnotetext{
${ }^{39}$ A felkelésellenes hadviselés hasonlóképpen részét képezheti egyedi esetekben a békekikényszerítő (peace enforcement) és a békefenntartó (peacekeeping) müveleteknek.

${ }^{40}$ A történelmet, a mủveleti környezetet, a jövő lehetséges müveleti körülményeiről kialakított feltevéseket kombinálja annak érdekében, hogy a hadsereg vezetőinek gondolkodását segítse a mindenkori küldetés sikeres teljesítése érdekében.
} 
dzsihádi mozgalmon belül három irányzatot különböztetünk meg Fawaz Gerges felosztása alapján:

- irredenta, amely elveszett területek visszaszerzéséért küzd,

- vallási nacionalista, amely a „közeli ellenség”, vagyis országa kormánya ellen harcol,

- vallási internacionalista, amely az országok kormányait támogató „külső ellenséget”, elsősorban az Egyesült Államokat támadja. (Gerges [2009] 2. о.) 


\section{I.FEJEZET}

\section{A FELKELÉS PROBLEMATIKÁJA A KLASSZIKUS SZAKASZ SZERZŐI SZERINT}

Az alábbiakban arra keresünk választ, hogy a második világháború után a dekolonizációs és egyéb irreguláris konfliktusokra milyen elméleti áramlatok voltak hatással, illetve jellemezték azokat. Ennek érdekében többek között Mao Ce-tung és Carlos Marighella munkáit fogjuk alapul venni a felkelői oldalon és Roger Trinquier, David Galula, Robert Grainger Ker Thompson és Frank Kitson müveit a felkelésellenes oldalon.

\section{A felkelés felértékelődése}

A második világháború olyan politikai ébredési folyamatot indított el, amely a háború után a felkelések számára kedvező közhangulatot teremtett. Emellett a modern világ vívmányainak elterjedése, mint pl. a rádióé, sok tekintetben megkönnyítette a felkelők helyzetét.

Frank Kitson a felkelések felértékelődését három okra vezette vissza:

1. nacionalista lelkesedés a második világháború után az antikolonializmus kontextusában,

2. Szociális elégedetlenség és rasszista indítékok,

3. a homogenitás megbomlása, a feudalizmus bukása, a lakosság jövőhöz való viszonyának megváltozása.

Az okok mellett rámutatott arra is, hogy a rádió és a televízió terjedésével az emberek befolyásolása sokkal könnyebbé vált. A felkelő és a szubverzión dolgozó általában hatékonyabban képes használni ezeket az eszközöket, mint a felkelésellenes erő, amelynek nagyobb erőfeszítésekre van szüksége. (Kitson [1991] 16-17. o.)

Roger Trinquier a nemzetközi rendszer megváltozására hívta fel a figyelmet: „Régen, föleg a 19. században, amikor fegyveres bandák keltek át egy tengerentúli francia birtokra, utánuk mentek. Ha szükséges volt, megtámadták a nekik menedéket adó országot, és megadásra kényszeritették. A néhány nagyhatalom közötti egyezmények elegendöek voltak a konfliktus lokalizálására, általában olyan incidensek 
kapcsán, melyeken a hadseregünk egyszerüen úrrá tudott lenni. Ma a nemzetközi szervezetek hatalma és a világ problémáinak bonyolultsága miatt ez a fajta beavatkozás reakciókhoz és talán a konfliktus kiszámithatatlan kiterjedéséhez vezet az egész világon." (Trinquier [1985] 101. o.)

Galula a második világháborúval bekövetkezett fordulatot emeli ki, amikor azt írja: „, 1938 elött egyetlen felkelés vagy lázadás sem járt sikerrel a gyarmatokon, igaz, a szituáció akkoriban kevésbé volt forradalmi, mint a háború után." ${ }^{41}$ (Galula [1964] 25. o.) Meggyőződéssel állította, , hogy a második világháború eredménye a (...) gyarmati felkelések sorozata, ami jelentős válságba taszitotta a gyarmattartó hatalmakat." (Galula [1964] 24. o)

Mao Ce-tung A gerillaháborúról címü müve 1937-ben jelent meg, de széles körben csak a második világháború után vált ismertté. Megírása idején a japán hadsereg volt Kína számára a legfőbb fenyegetés, és a japán beavatkozásig dúló polgárháború éppen szünetelt. Kínának jó adottságai voltak a gerilla hadviseléshez: nagy, nehezen megközelíthető, rosszul ellenőrzött, ritkán lakott területek, átpolitizálható lakosság és egy idegen, agresszív ellenség. Másfelől Kína egy sajátos fejlődési szakaszban volt: nem kis mértékben a japán-kínai háború hatására a korábbi társadalmi rend az összeomlás szélén állt, ami a kommunista párt számára nagy lehetőséget jelentett.

A katonai cselekményeket és a gerilla hadviselést ennek fényében tárgyalja Mao. Megállapítja a müvében több helyen is, hogy a gerilla hadviselés a körülmények szükségszerüségéből adódik, illetve a tömegek bevonásának, „emancipálódásának” lehetőségét jelenti, de nem szabad önálló hadviselési formának tekinteni. A mü fö üzenete, hogy a gerilla erőknek idővel konvencionális erőkké kell fejlődni annak érdekében, hogy képesek legyenek az ellenséges erökön felülkerekedni. (Mao [1989] 41-43. o.) Ezt nevezték később ortodox maoista megközelítésnek.

A gerilla hadviselés és a lakosság kapcsolatának vizsgálatakor kifejti, hogy „a gerilla hadviselés alapvetöen a tömegekböl indul ki és támogatásukat élvezi, nem létezhet és nem virágozhat az emberek szimpátiája és támogatása nélkül." (Mao [1989] 43. o.) Ezért a célokat - főként hatékony kommunikációval - meg kell értetni és el kell fogadtatni a lakossággal, mert a meggyőzés fontosabb az erőszaknál. (Mao [1989] 89. o.) Példaként a következő szabályokat és az azokhoz füzött megjegyzéseket hozta fel a lakossággal való megfelelő kapcsolattartásra:

\footnotetext{
${ }^{41}$ Kevés kivétel azért volt: Holland Kelet-India (1926-1927) és a Gandhi vezette passzív ellenállási mozgalom
} 
Szabályok:

1. Minden akció a parancsnokság alá van rendelve.

2. Ne lopj az emberektől!

3. Ne légy önző és igazságtalan!

Megjegyzések:

1. Tedd be az ajtót, ha elhagyod a házat!

2. Tekerd össze az alvóhelyet, amit használtál!

3. Légy udvarias!

4. Légy őszinte a pénzügyi ügyleteidben!

5. Add vissza, amit kölcsönkértél!

6. Pótold, amit összetörtél!

7. Ne fürödj nők jelenlétében!

8. Felhatalmazás nélkül ne vizsgáld át azok zsebeit, akiket letartóztatsz! (Mao [1989] 92. о.)

A gerillák képesek voltak a helyi közösségek részeként létezni, a hírszerzést és az egyéb igényeik kielégítését is (pl.: élelmezés, ruházat) meg tudták oldani a helyiek segítségével, és ez megnehezítette az ellenséges erők dolgát. A harci cselekményeket illetően a megtévesztés, a gyorsaság és az ellenséges fellépéshez való alkalmazkodás erényeit emeli ki, a következőképpen: „Ha a gerillák egy erösebb ellenséget támadnak, visszavonulnak, amikor visszatámad; zaklatják, amikor megáll; támadják, amikor fáradt; követik, amikor visszavonul." (Mao [1989] 46. o.)

Mao müvének hatása megkérdőjelezhetetlen. A világháború után rendkívül széles körben elterjedt, sok nyelvre lefordították, és számos konfliktusban használták forrásként. Angolul 1952-ben adták ki Kínában, angliai kiadása 1961-ben jelent meg. Ehhez írott előszavában Samuel B. Griffith az alábbiakat emelte ki a forradalmi háborúk sikerével kapcsolatban:

1. A demokratikus modell a fejlődő országokban a szűk középosztály miatt nem müködö modell,

2. a fiatalság eleve az erőszakos megoldásra törekszik,

3. a müveletlen rétegek irányába olyan ígéreteket tartalmaz, amelyek vonzóak, de sejthetik, hogy nem fognak teljesülni. (Mao [1989] 6. o.)

Griffith fontosnak tartotta megjegyezni, hogy az olyan nyugati értékek, mint a vallásszabadság, a sajtószabadság, vagy éppen a vállalkozás szabadsága nem érnek túl sokat az olyan helyeken, ahol a megélhetés az alapvető probléma, és az erőszakos 
fellépést tekinthetik az egyetlen járható útnak a változás kierőszakolására. (Mao [1989] 6. o.)

Mao témánk szempontjából másik fontos müve Az elhúzódó háborúról című, 1938-ban megjelent kötet, amelyben a sokszor hivatkozott maoi népi háború szakaszainak leírása található. Három szakaszt különböztetett meg, úgymint: stratégiai defenzíva, stratégiai patthelyzet és stratégiai offenzíva.

A stratégiai defenzíva a felkelői oldal számára a politikai szervezés és a gerilla hadviselés alapjai megteremtésének időszaka. A fö feladat külföldi támogatás szerzése és bázisterületek létrehozása a gerillaharc folytatásához. A felkelő erő jelentős hátránya és a felkelésellenes erő erőfölénye jellemzi mind katonailag, mind gazdaságilag. A felkelő erőnek a politikai mozgósítás, külföldi támogatók megszerzése, a katonai tapasztalatszerzés és a különbségek csökkentése az elsődleges feladata a felkelésellenes erővel szemben.

A stratégiai patthelyzet szakaszában a felkelők a gerilla hadviselésre koncentrálnak (amit kiegészíthet konvencionális hadviselés), az ellenség gyenge pontjait támadva, széleskörü harcokat gerjesztve. A szakasz időbeli hossza attól függ, hogy milyen módon változik az erők egyensúlya. Jelentős gazdasági és fizikai károkkal járhat, a nemzetközi helyzet is befolyásolhatja. Ennek ellenére a politikai mozgósításnak nagyobb méreteket kell öltenie, a nemzetközi támogatást növelni kell, és törekedni kell az ipari kapacitások fejlesztésére. Ez a szakasz hosszú ideig tarthat, és az erők egyensúlyának/erőegyensúly kedvező változása vezeti át a harmadik fázisba.

A stratégiai offenzíva során az első és a második fázisban felépített erőkkel konvencionális támadást indít az ország teljes területének visszaszerzésére. Fontos a nemzetközi támogatás biztosítása ehhez, ami intenzív diplomáciai fellépést és propagandát igényel. A gerilla hadviselés ekkor a konvencionális fellépést támogatja. Ez a fázis a hadszíntéren kialakult különbségek miatt nem minden területen egyformán zajlik. 


\section{3. táblázat A maoi három fázis a felkelők és az ellenség szemszögéből}

\begin{tabular}{|l|l|}
\hline \multicolumn{2}{|c|}{ Maoi fázisok } \\
\hline \multicolumn{1}{|c|}{ a felkelők szemszögéből } & az ellenség szemszögéből \\
\hline a stratégiai defenzíva szakasza & stratégiai támadásának szakasza \\
\hline a stratégiai patthelyzet szakasza & stratégiai konszolidációjának szakasza \\
\hline stratégiai offenzíva szakasza & stratégiai visszavonulásának szakasza \\
\hline
\end{tabular}

Forrás: Mao [2004]

Mao nagy jelentőséget tulajdonít mindhárom fázisban a politikai egység megtartásának, mivel csak így tartható fent a háborús erőfeszítés a győzelemig. Három tényezőt tekint központinak a győzelemhez: a saját kapacitások fejlesztését és növelését, az ellenség helyzetének gyengülését és a nemzetközi támogatást. A lakosság támogatásának a biztosítását tartja elsődlegesnek, mivel a gazdasági és a katonai hatalom is a lakosságból fakad. Figyelmeztet arra, hogy a háború lerövidítése céljával indított elhamarkodott konvencionális fellépés, amely nem veszi figyelembe a relatív erőegyensúlyt a harcoló felek között, bukásra van ítélve. Ugyanakkor arra is figyelmeztet, hogy ha az első fázisban a veszteségek túl nagyok, a második pedig túl hosszúra nyúlik, akkor a politikai egység fenntartása felettébb nehéz lesz. Bár Mao mindezt a Japán elleni háborúval kapcsolatban írta le, később is széles körben alkalmazták, elsősorban a gerillaháborúkkal kapcsolatban.

\section{Szubverzió és felkelés}

A két fogalom jelentésének meghatározására Kitson adta a legpontosabb definíciót. E szerint a szubverzió illegális lépéseket jelent „az ország lakosságának egy része által, amelyek nem érik el a fegyveres konfliktus szintjét az aktuális kormányzat megdöntésére vagy a kormányzat olyan intézkedésekre kényszeritésére, amelyeket az nem akar végrehajtani. Politikai és gazdasági nyomás a részét képezheti, de ide tartozhat a csekély mértékü eröszak alkalmazása a vonakodó lakosság támogatásának biztositására.” A felkelés ,, a lakosság egy része által alkalmazott fegyveres erőszak a kormányzat ellen." (Kitson [1991] 3. o.)

A szubverzió és a felkelés folyamata egyidőben is végbemehet, nincsenek szigorú választóvonalak. A különbség köztük az erö alkalmazásának formájában van: a szubverzió célja a lakosság meggyőzése az uralmon lévő hatalom önkéntes 
megdöntéséről és a potenciális felkelő föszereplésével létrehozott másik hatalommal való felváltásáról. Vagyis a szubverzió, bár a belföldi konfliktus egy formája, az erőszak alkalmazását tekintve messze elmarad a felkelés mögött. Az aránytalanságtól eltekintve azonban mind a felkelésben, mind a szubverzióban az erőszak a meggyőzést, illetve annak megerősítését szolgálja. Kitson szerint ez markáns eltérés a konvencionális háborútól, mivel ott a meggyőzést az erő alátámasztására alkalmazzák. (Kitson [1991] 4-6. o.)

A szubverzív, majd pedig felkelő szervezet kiépítése sok időt és körültekintést igényel. Fázisai:

1. frontszervezet vagy párt létrehozása (vagy egy meglévő átvétele, de ez valószínütlen) az ideológia terjesztésére

2. a szervezet országos szintüvé tétele

3. sejthálózat létrehozása (gyárakban, farmokon és más fontos területeken), célja támogatás vagy pozitív semlegesség elérése, erőforrások, pénz, információk biztosítása

4. megfelelő propaganda (írott, nyomtatott és elektronikus, ami kezdetben nem éri el a hatóságok ingerküszöbét) és zsarolás, illetve erőszak alkalmazása, ha kell (Kitson [1991] 34-35. o.)

A mozgalom vezetőinek két külön, de szorosan összefüggő feladatuk van: megszerezni a lakosság egy részének támogatását és ráerőltetni az akaratukat a kormányzatra fegyveres győzelemmel vagy hosszas kimerítő hadjárattal. Az időrendet tekintve a lakossági támogatást egyértelmüen célszerü és általában szükséges a müveletek megindítása előtt megszerezni. (Kitson [1991] 32. o.)

A szubverziós időszak azért fontos, mert ezalatt dől el, hogy a szubverzió önmagában elegendő-e, vagy szükség lesz fegyveres harcra. A felkelés a szubverzió sikerének és kudarcának egyidejü terméke, amennyiben a szubverzió eljuttatta arra a pontra a kormányzatot, hogy megindíthassák ellene a felkelést, de ahhoz elégtelennek bizonyult, hogy közvetlenül megdöntsék a kormányt. (Thompson [1966] 28. o.)

Sikertelen szubverziós szakasz esetén kerül sor felkelésre, ami széleskörü tevékenységet ölel fel az egyes személyek által elkövetett szabotázsakcióktól egészen a nagy fegyveres csoportok létrejöttéig és müködéséig. A fegyveres csoportok fejlődésének menetétől függően nyílt polgárháború is kialakulhat. (Kitson [1991] 6. o.)

Az erőszakmentes szubverzió szerepe fontos, de a megvalósulása éppen úgy, mint az előkészítése, hiányos szegmense a szakirodalomnak. Az alábbiakban ezt a kérdéskört 
igyekszünk röviden körüljárni. Az első és legfontosabb szempont az erőszakmentes szubverzió esetében, hogy nehéz megkülönböztetni a legitim ellenzéki fellépéstől. Számos célt kizárólag erőszakmentes fellépéssel lehet elérni (pl.: a kormányzat meghátrálása, valódi tömegmozgalom kiépítése stb.). A felkeléssel párhuzamosan alkalmazva célja lehet a katonák elvonása a fegyveres harctól, a világ közvéleményének felhívása, a kormány plusz kiadásokra kényszerítése, de lehet egy folyamatban lévő városi terrorakció és szabotázssorozat része is.

Kitson szerint a téma vizsgálatakor fontos figyelembe venni, hogy az erőszakmentes mozgalmak vezetői sokszor nem morális, hanem praktikus alapon döntenek az erőszakmentesség mellett, és hajlandóak együttmüködni erőszakot alkalmazó csoportokkal. Ha pedig olyan lesz a helyzet, hogy erőszakos fellépéssel többet gondolnak elérni, felhagyhatnak vele. Az erőszakmentes fellépést sokszor kísérheti terrorizmus és szabotázs. Az erőszakmentes fellépés magában hordozza az erőszakossá válás esélyét, amennyiben a szervezők vagy a hatóságok elveszítik felette az ellenőrzést, vagy ha az erőszakos megoldás mellett kiálló kisebbség, esetleg provokátorok a saját céljaik elérésére használják. Hangsúlyozza, hogy az erőszakmentes fellépést nem szabad automatikusan szubverziós kísérletnek tekinteni, mivel az a legtöbb esetben nem veszélyes az államhatalomra.

Erőszakmentes szubverziós megmozdulást nagyon nehéz megszervezni és fenntartani, rengeteg időt, energiát és pénzt igényel, a siker pedig egyáltalán nem garantált. Nagy számban kell hozzá megnyerni embereket, akik hajlandóak feláldozni a szabadidejüket politikai okokból (általában csak egy szük idealista réteget lehet ilyen módon mozgósítani, és nem ők a szervezők célcsoportja). A résztvevők köre és létszáma változó, emiatt a fegyelmezettség szintje sem állandó, ami problematikussá teszi az irányítást. Egy ilyen csoport sebezhetősége biztonsági szempontból nagy, hiszen a hatóságok könnyen be tudnak szivárogni és akadályozni tudják a tevékenységét. Jobban függ a hatóságok fellépésétől, mint egy titkos szervezet, de ideális esetben jóval nagyobb nyomásgyakorlási potenciállal rendelkezik.

Ahhoz, hogy egy akció sikeres legyen, növelni kell a benne résztvevők számát, ha pedig ez bekövetkezik, az összeütközések száma is növekedni fog. Ha a kormány nem érti meg a fenyegetést és nem megfelelően reagál, akkor ebből komoly problémái lehetnek. (Kitson [1991] 82-87. о.) 
Gene Sharp nem erőszakos ellenállási klasszifikációja segíti a módszerek közti eligazodást. Sharp összesen 198 módszert különböztet meg, amit öt nagy tevékenységi körbe sorol:

1. erőszakmentes tiltakozás és meggyőzés

2. Szociális együtt nem müködés

3. a gazdasági együtt nem müködés (bojkott és sztrájk)

4. a politikai együtt nem müködés

5. erőszakmentes beavatkozás

Az öt tevékenységi körbe sorolt módszerek altípusokra tagolódnak, a politikai együtt nem müködés módszerei pl. hat altípusra:

1. a tekintély elutasítása (három módszer)

2. polgári engedetlenség (kilenc módszer)

3. polgárok alternatív hüsége (nyolc módszer)

4. kormányzati foglalkoztatásban lévők fellépése (hét módszer)

5. belpolitikai kormányzati fellépés (két módszer)

6. nemzetközi kormányzati fellépés (hét módszer) (Sharp [nincs datálva])

A felületes vizsgálat is mutatja, hogy egy szervezett erőnek számos eszköz áll a rendelkezésére a fennálló kormányhatalom legális keretek közötti kihívására a hagyományos politikai kereteken túl. Ennek fontosságát nem szabad alábecsülni.

\section{A felkelés megindulásának szükséges körülményei}

A klasszikus szakaszban a vidéki alapú kommunista felkelés jelentette a legnagyobb kihívást. Thompsonnak A kommunista felkelés legyőzése (1966) címü munkája szerint a gyakorlatban a legfontosabb tényező egy felkelés megindulásához, hogy az állam közel álljon a vidéki igazgatási képességeinek összeomlásához, vagy már ebben az állapotban legyen. Ennek érdekében a felkelök mindent megtesznek a kormányzat diszkreditálására. Fontos a potenciális ellenfelek megsemmisítése. Azokat, akikre a lakosság vezetöként tekinthet, a kommunisták igyekeznek megölni (falusi vezetők, főmunkások, neves helyiek). A népszerű embereket „csak úgy” nem ölik meg, előbb diszkreditálják őket. Ezt elérhetik azzal, hogy népszerütlen kormányzati politikával hozzák őket kapcsolatba, korrupcióval vagy nemi erőszakkal gyanúsítják meg őket (pl.: női pártaktivisták segítségével, akik hajlandóak egy színlelt nemi erőszak 
vállalására). Ennek a politikának, amit szelektív terrorizmusként is le lehet írni, az a célja, hogy a vidéki lakosságot félelemben tartsa.

A kommunista felkelők ügyelnek arra, hogy ne alkalmazzanak nagyarányú terrort a lakossággal szemben. Csak kivételes alkalmakkor nyúlnak ehhez az eszközhöz, mert tudják, hogy a túlzott terror alkalmazása könnyen a kormányzat irányába fordítja a lakosságot. A szelektív terror hatékonyabb. Szigorú fegyelem kell a betartásához, de ezzel mutathatják, hogy a szándékaik jók a lakosság nagy részével szemben. Mao írása szerint is fontos a jó magaviselet, hogy a kormányzati rossz magatartással szembe lehessen állítani, ennek megfelelően a vitatott területeken fizetnek az ellátmányért stb. A felkelések során azonban a megtorlás olyan terrorral párosul, amihez foghatót nyugaton elképzelni is nehéz. (Thompson [1966] 24-25. o.)

Galula fontos szerepet tulajdonít a földrajzi adottságoknak. Az ország mérete, földrajzi tagoltsága, határainak jellege, éghajlata, lakosságának összetétele és mérete, valamint gazdasági fejlettsége mind fontos tényezők egy felkelés kitörésének lehetséges körülményeinél. Szerinte a legideálisabb egy csak szárazföldi, hosszú határokkal rendelkező, hegyes és erdőkkel borított ország, melynek alacsony a népsürüsége és gazdaságilag fejletlen. (Galula [1964] 27-28. o.)

Fontos, de nem nélkülözhetetlen feltétel, hogy a felkelők külföldi támogatást tudjanak szerezni.

A felkelöknek vonzó okra van szükségük ahhoz, hogy a korai szakaszban szélesebb támogatottságra tudjanak szert tenni, illetve aktív támogatókat tudjanak szerezni, akik hosszú távon nem feltétlen ugyanazok, de önként, vagyis meggyőződésből állnak mellettük.

Több stratégiai kritérium határoz meg egy felkeléshez alkalmas okot:

1. Sok követőt hoz, és kevés embert rettent el.

2. A felkelő azonosulhat vele a lakosság nagy részének szemében.

3. A felkelésellenes erő nem használhatja fel anélkül, hogy elveszítse a hatalmát.

4. Hosszú távúnak kell lennie, ha nem is a háború teljes idejére, de a mozgalom megerősödésének idejére ki kell, hogy tartson (ez különbözteti meg a stratégiai és a taktikai okokat, illetve a mélyről jövő okokat és az ideiglenes okokat, amelyek egy ideiglenes helyzet kiaknázására épülnek).

A jó ok általában valamilyen politikai ellentmondás, amely az ország belső vagy nemzetközi helyzetével kapcsolatos. Akkor igazán nagy horderejü, ha az elitet 
megosztja, mivel akkor a felkelés egy alkalmas vezetői rétegből építkezhet. Jellegét tekintve az ok lehet gazdasági, szociális, faji, vallási stb. Nem fontos, hogy a probléma természete égető legyen, de ha így van, akkor a felkelő első feladata, hogy akuttá tegye. Ennek gyors eszköze lehet az erőszak.

Nem kell egy okra korlátozni a választást. A korszakban voltak olyan különösen hatékony okok, mint az antikolonializmus, amely egyesítette magában a politikai, szociális, gazdasági, faji, vallási és kulturális okokat. Több, egymással nem feltétlenül összefüggő okot is lehet választani. Ha egy új ok politikailag több elönyt kínál, a régi elhagyható. Az ok fontossága a felkelés előrehaladásával folyamatosan csökken. Egyre inkább a háború maga lesz a fő téma, rákényszerítve a lakosságot, hogy oldalt válasszon. (Galula [1964] 13-19. o.)

Amennyiben nincs nyomós ok, akkor a felkelőnek kell kreálnia: vagy egy meglévő okot kell kiegészíteni addig, amíg elegendő ember mögé nem áll, vagy egy vonzerejét vesztett okot kell újból népszerüvé tenni. Jó ok nélkül az egész vállalkozás reménytelen. Kitson példaként említi, hogy a kommunistáknál bevett módszer volt az okok szélesebb körü meghatározása, pl. patrióta témák felvetése. (Kitson [1991] 29-30. o.)

\section{Felkelői stratégia}

A felkelők lakossághoz való viszonya és annak szerepe központi kérdés a felkeléseknél. Trinquier azt írja erről, hogy ,, nem fegyveres szervezettel küzdünk, amit a tradicionális vonalak mentén szerveztek, hanem egy titokban müködö szervezet fegyveres egységeivel, melyek egy speciális szervezet által manipulált lakosság soraiban müködnek.” A felkelésellenes erő számára a győzelem a felkelő szervezet elpusztítását jelenti. (Trinquier [1985] 8-9. o.)

Galula szerint a felkelőnek alapvetően politikai célt kell megvalósítani, meg kell nyerni és a maga oldalára kell állítani a lakosságot, míg a felkelésellenes erőnek a maga oldalán kell tartani, vagy legalább az engedelmességét megtartani. A felkelőnek ehhez egy politikai-katonai szervezet áll rendelkezésére, ami klasszikus esetben a kommunista párt vezette felkelő szervezet. Ez jelentős előnyhöz juttatja a felkelői oldalt, mivel mind a fegyveres, mind a politikai része jóval összefogottabb, egységesebb, mint az ellene fellépő kormány vagy fegyveres erő. A felkelő célja káosz szítása, mivel az 
elégedetlenséget teremt. Káoszt egyszerűen, akár nyilvános fenyegetésekkel is elő lehet idézni. (Galula [1964] 7-9. o.)

Galula két stratégiát különböztet meg: az ortodox kommunista és a burzsoá nacionalista utat.

Az ortodox kommunista útnak öt fontos lépcsője van:

1. párt létrehozása

2. egyesült front létrehozása

3. gerilla hadviselés

4. konvencionális háború

5. megsemmisítő hadjárat

A párt létrehozása Galula értelmezésében már a felkelés előkészítésére való felkészülés, ennek megfelelően egy nyílt és egy titkos apparátust is létre kell hozni. Összetartó, egységes szervezetre van szükség, ami nemcsak katonai győzelemre képes, hanem az utána kialakult helyzet kezelésére is.

Az egyesült front létrehozásának lényege a kommunista párt súlyának és támogatásának növelése. A szövetségeseket, ha nem megbízhatóak, lehetőség szerint be kell vinni a pártba. Nem szabad meghagyni az önállóságukat, és szem elött kell tartani, hogy veszélyt jelenthetnek. Az agitáció, a propaganda és az erőszakmentes szubverzió mind fontos eszköz ebben a fázisban a célok megvalósítására. A tempót a leendő felkelő határozza meg.

A gerilla szakasz akkor indul meg, amikor a szubverzív eszközök alkalmazása csődöt mond. A célja bázisok megszerzése, együttmüködés kialakítása a lakossággal és a felkelésellenes erők demoralizálása. A katonai eszközök alkalmazását soha nem szabad elsődleges célnak tekinteni, mert ha az a lakossági támogatás gyengítését eredményezi, a katonai taktikai siker ellenére is kudarcnak tekinthető.

A konvencionális szakasz előkészítésének elengedhetetlen feltétele, hogy a széttöredezett felkelő csoportokat és müveleteket összhangba hozzák, aminek fontos eleme a közös doktrína kidolgozása. A konvencionális szakasz saját erőforrásokból vagy külföldi segítséggel megteremtett konvencionális erő létrehozásával indulhat meg. Ez kezdetben nem jelent a kormányoldallal egyenértékü fegyverzetü vagy doktrínájú erőt, de elméletben idővel itt is történik elörelépés.

A megsemmisítő hadjárat az erők kiegyenlítődése utáni szakasz, amikor a felkelő kerül fölénybe a kormányoldallal szemben, és ennek végén a felkelő lesz az egyetlen legitim politikai és katonai erő az adott területen. 
A burzsoá nacionalista út esetében a hatalom megszerzése az elsődleges cél, minden más háttérbe szorul. Emiatt általában nem nagy csoportok választják ezt az utat. Ebböl következik, hogy a szervezet kisebb, az erőszak szórványos, ugyanakkor látványosabb. De a müködés kockázata nagy, mivel a terrorizmus a visszájára sülhet el, és megsemmisülhet az évek kemény munkájával felépített titkos szervezet.

$\mathrm{Az}$ ortodox kommunista és a burzsoá nacionalista út egyaránt veszélyeket rejt magában. Az ortodox megoldásnál a pártszervezés és az egyesült front megteremtése a hatóságok szándékának van kitéve. Amint a felkelésellenes erő érzékeli a veszélyt, igyekszik lecsapni. Amennyiben ezt nem teszi elég keményen és pontosan, és a felkelő erő túléli ezt a szakaszt, hozzákezdhet a katonai erejének kiépítéséhez. Ez a legveszélyesebb szakasz, de ha túléli, akkor nem lesznek olyan hiányosságai, amelyek lehetetlenné teszik a harc folytatását. A burzsoá-nacionalista út esetében a csoport titkos eszközökkel müködik, a korai müködésnél a veszélyeztetettsége a terrorizmus alkalmazása miatt nagymértékben megnő, és ki van téve a rendőrség és a cenzúra hatékony fellépésének. Előnye a meglepetés és a felkelésellenes erő késleltetett reakciója. (Galula [1964] 34-46. o.)

\section{A felkelés szervezete}

A klasszikus felkelő szervezeteknek - amint erről már szóltunk korábban - van politikai és katonai águk Müködésüket az algériai példán - az FLN és az ALN kapcsolatán - keresztül lehet a legjobban megismerni és megérteni. Az FLN és az ALN ugyanolyan földrajzi felosztásban müködött, de egymástól elszigetelten. Együttmüködtek minden körzetben, de a regionális tanács volt a felelős a koordinálásért. A tanács általában négy tagú. A döntés közös, a legnagyobb felelösség a vezetőé. A tagok:

1. politikai-katonai vezető

2. politikai helyettes

3. katonai helyettes

4. külső összekötő és hírszerzési helyettes

Az FLN szervezet háromfös félsejtre épült a körzetekben, felette a sejt, a félcsoport, a csoport és az alkörzet a körzeti parancsnok felügyelete alatt, aki így 127 ember felett rendelkezett. Az ALN szervezete ugyanezen a szinten 35 főből állt. A körzeti parancsnok és a helyettese három csoportot vezetett. Mindegyik csoport élén egy 
vezető és egy helyettes állt, egy csoport három félsejtből tevődött össze. A politikai szervezetnek is voltak fegyveres csoportjai, amelyek azonban föként rendfenntartó feladatokat láttak el, valamint az árulók kivégzését hajtották végre a jogi ág utasításai alapján.

A felső vezetés önkéntes volt és ideológiailag képzett. Az alacsonyabbat a város keményebb részeiből toborozták, és általában bünözői hátterük volt. A későbbiekben folyamatos volt a toborzás, így tudták a szervezetet utánpótlással ellátni és a veszteséget kompenzálni.

A külső összekötő és hírszerzésért felelős helyettes a tanácsban több bizottságra is számíthatott (pl.: információs, szerkesztői, jogi, pénzügyi, egészségügyi, szakszervezeti bizottság). A szervezet több eltérő és egymástól elválasztott ágra bomlott, amelyek közvetett kommunikációs csatornákat használtak. (Trinquier [1985] 10-14. o.)

Ettől gyökeresen eltérő modellt valósítottak meg Kubában. A „foco” megközelítés lényege, hogy a felkelés előfeltételei egy kis csoport ráhatásával is elérhetőek. Ebben a megközelítésben nincs szükség pártra, a gerilla a párttag. (Guevara [2007] 27-34. o.)

\section{Felkelöi propaganda}

A felkelői propaganda szerepével keveset foglalkoznak a szerzők. Galula megemlíti, hogy mivel a felkelőnek nincs semmilyen kötelezettsége a lakosság irányába, szabadon használhat bármilyen trükköt, ha kell, hazudhat vagy túlozhat. Az alapján ítélik meg, amit ígér, és nem az alapján, amit tesz. Ennek megfelelően a propaganda fontos eszköze a felkelésnek. (Galula [1964] 11. o.)

Thompson egy rádióadást hoz fel példának, amelyben a Vietnami Nemzeti Front alábbi ígéretei hangzottak el:

1. Minden politikai fogoly feltétel nélküli szabadon engedése.

2. Minden tömegmozgalom és párt szabadságának garantálása.

3. Szabad sajtó és a véleménynyilvánítás szabadsága.

4. Az alkotmány eltörlése és a törvényhozás feloszlatása.

5. Új, demokratikus törvényhozási választás megtartása, ami dönteni fog a jövendő rezsim jellegéről.

6. Az amerikai kereskedelmi monopólium eltörlése; technikai és gazdasági segítség elfogadása minden államtól. 
7. Minden ország kultúrájából való tanulás, a politikai berendezkedéstől függetlenül.

8. Semlegesség biztosítása azzal, hogy minden állammal diplomáciai kapcsolatot létesítenek (a bandungi alapelveknek megfelelően), és semmilyen katonai tömbhöz nem csatlakoznak.

9. A békés újraegyesülés ügyének továbbvitele. (Thompson [1966] 22-23. o.)

Ebben az üzenetben sem a szocializmus, sem a kommunizmus, sem a társított politikai képzetek nem jelennek meg. Egyszerüen megígér mindent, akár lehetséges a megvalósítása, akár nem.

\section{Az erőszak szerepe}

A felkelőnek addig nem érdeke kihívni maga ellen a kormányzatot, amíg nem biztos abban, hogy ki fogja bírni az ellentámadást. Megvan az a helyzeti előnye, hogy az erőszak visszatartásával csökkenteni tudja az általa jelentett veszélyt a kormányzat szemében, és ugyanezzel a lakosság szemében is sikeresebb lehet, ami további előny. A fegyveres harc elhúzódó volta a felkelő gyengeségéből fakad (időbe telik fegyveres erőket kiépíteni és ezzel a kormányt legyőzni). Gyors győzelemre csak akkor számíthat, ha a kormány a saját gyengesége miatt gyorsan megbukik. (Galula [1964] 8. o.)

Az időzítésnek hatalmas szerepe van: ha elnyúlik, akkor van rá esély, hogy a kormányzat a szubverziós periódus alatt azonosított vezetést letartóztatja, vagy pedig a kormányzati reformok elkezdik kifejteni a hatásukat, csökkentve a felkelök felé irányuló támogatást; ha túl korai, lehetséges, hogy a hatékony kormányzati ellenintézkedések hatására a teljes mozgalom összeomlik. (Thompson [1966] 28-29. o.)

A felkelők fő törekvése, hogy a kormányzatot bizonytalanságban tartsák a támadások irányát illetően, pánikot okozzanak a lakosságban, és zavart keltsenek a gazdaságban. A célok elérése érdekében egy közös politikai-katonai szervezetet hoznak létre, amelyben a katonai rész alá van rendelve a politikai ágnak. A gerilla csoportok elsődleges célja - a folyamatos szubverzió és terror által - mindig a politikai célok támogatása a lakosság feletti irányítás megszerzése érdekében. A gerilla hadviselési szakasz stratégiai célja, hogy politikai irányítást szerezzen a lakosság felett a vidéki területeken, és rombolja a kormányzat presztízsét és tekintélyét. A katonai cél az, hogy semlegesítsék a kormányzat katonai erejét, és képtelenné tegyék őket az ország feletti irányítás visszaszerzésére. (Thompson [1966] 29-30. o.) 
Trinquier is a terrorizmust emeli ki, mint fontos eszközt, mivel ennek segítségével a lakosság feletti befolyás biztosítása leegyszerüsödött a felkelő oldal számára. A folyamatos létbizonytalanság, amit a folyamatos erőszak teremt, és a tény, hogy az államapparátus nem képes a polgárt megvédeni, olyan tényező, ami könnyen legalább hallgatólagos együttmüködésre bírhatja a polgárokat. Az állam képességeibe vetett hitük mindenképpen megrendül. (Trinquier [1985] 16-17. o.)

Galula a felkelő szervezetek müködésében kétféle terrorizmust különböztet meg:

1. Vak terrorizmus, amikor a mozgalmat és célját terrorcselekmények általi figyelemfelkeltéssel próbálják előtérbe állítani, lehetőleg látványos eszközökkel.

2. Szelektív terrorizmus, amely gyorsan követi az előbbi fázist. Célja a felkelésellenes erők elszigetelése a lakosságtól, általában alacsony rangú helyi tisztviselők megölésével és egyéb intézkedésekkel, mint pl. forradalmi vagy egyéb adó szedése. A felkelő szempontjából legfontosabb dolog, hogy megszüntessen minden kapcsolatot a felkelésellenes erö és az irányítása alá került lakosság között. (Galula [1964] 43-44. o.)

A hatóságok számára nehéz feladatot jelent, hogy észlelje a felkelő szervezet tevékenységének kezdetét. A szervezet működése a titoktartás miatt lassú és körülményes. A védtelen területeken, például a lakatlan vidéki területeken, ahol a rendőrség létszáma minimális, a felkelő nem találkozik ellenállással, ezért ilyen területen kezdi meg a tevékenységét. A gerilla szakasz kezdeti lépései:

1. elszigetelt támadások a vidéki területeken

2. a lakosságot megfélemlítik

3. szelektív terrorizmus indul meg: megölnek olyan alacsony beosztású személyeket (pl. rendöröket és bürokratákat), akik nem értették meg a figyelmeztetést

4. a végeredmény: csend és együttmüködés a lakosság részéről

5. a fegyveres csoportok ezután be tudnak férkőzni a lakosság soraiba (Trinquier [1985] 19. o.)

A beférkőzés a gyakorlatban azt jelenti, hogy elkezdik kialakítani a gerilla infrastruktúraként ismert szervezeti rendszert. A politikai szervezet a felelős a lakossági befolyás kiterjesztésért, amelyben helyi és a nem helyi erők segítik. A helyi politikai szervezet a körzeti bizottság irányítása alatt áll. Ez a felelös a helyi és a nem helyi fegyveres csoportok élelmiszerrel, egyéb utánpótlással, újoncokkal, hírszerzési 
információkkal való ellátásáért. A helyi politikai szervezet kiterjesztésével és nagyobb területek feletti ellenőrzés megszerzésével az utánpótlás és az újoncok áramlása a körzeti szintre egyre nő. Így új egységeket lehet felépíteni szakasz szintről század, zászlóalj és ezred szintre. (Thompson [1966] 30-31. o.)

A politikai szervezet kiépítésének sajátosságaira Vietnamból lehet érdekes példát hozni. A Nemzeti Felszabadítási Párt (közismertebb nevén a Viet Cong) több szervezetet is létrehozott, ahová ajánlott volt a belépés. Ilyen volt a Felszabadító Paraszt Szövetség, a Felszabadító Ifjúsági Szövetség és a Népi Felszabadító Bizottság. Ezeken a szervezeteken keresztül egyszerübbé vált a lakosság ellenőrzése és beszervezése az árnyékkormányzati infrastruktúrába. A lakosság így jobban mozgósítható volt a szervezet céljaira. (Moyar [2007] 14. o.)

Egy jól müködő szervezetnek a városokban sem okozhat gondot a lakosság terrorizálása és a menekülés a hatóságok elöl. Carlos Marighella a városi gerilla tevékenységét tizennégy pontban foglalta össze. A felsorolásból látni lehet, hogy egyszerre tartalmaz erőszakos és nem erőszakos elemeket.

A városi gerilla tevékenység fajtái:

1. Támadások

2. Rajtaütések, behatolások

3. Megszállások

4. Lesállások

5. Utcai zavargások

6. Sztrájkok és munkaleállások

7. Dezertálás, diverzió, fegyverek, lőszer és robbanóanyagok lefoglalása

8. Foglyok kiszabadítása

9. Kivégzések

10. Emberrablások

11. Szabotázs

12. Terrorizmus

13. Fegyveres propaganda

14. Idegek harca (Marighella [2002] 21. o.)

A kormányzat a folyamat egy pontján bevonja a hadsereget, amelynek vezetői értelemszerüen a fegyveres csoportokat fogják a szervezet súlypontjának érezni, nem a politikai szervezetet, mivel az nem jó katonai célpont. Ennek az a következménye, hogy hiányos hírszerzési információkra alapozva indítanak nagyarányú katonai műveleteket a 
gerilla csoportok felderítésére és megsemmisítésére. A gerillacsoportok pontosan az ilyesfajta fellépésre vannak felkészülve. Általában nincsenek egy helyre koncentrálva, kivéve, ha saját akcióba akarnak kezdeni, és olyan területen vannak szétszórva, ahol eleve nehéz manőverezni. Még ha sikerül is egy részegységet megtámadni, az azonnal visszavonul. Még akkor sem fenyegeti komoly veszély a gerilla mozgalmat, ha néhány egységét sikerül bekeríteni vagy megsemmisíteni. A gerilla szervezetek sajátossága, hogy a veszteségeiket általában gyorsan tudják pótolni. (Thompson [1966] 30- 31. o.)

A gerilla fázisnak vannak politikai eredményei is, ezek a következők:

1. A kereskedelem gyakorlatilag áll.

2. A helyben termelt termékek ára növekszik.

3. A kormányzati bevételek csökkennek.

4. A pénz folyamatosan leértékelődik.

5. Folyamatosan csökken a kormányzat képességeibe vetett hit. (Thompson [1966] 42. о.)

Ahogy a gerilla fázis a csúcsára ér, a gerilláknak három lehetőségük van a politikai győzelem megszerzésére:

1. A klasszikus katonai győzelem kivívásának megkísérlése (Mao elképzelései mentén) - ez kockázatos megoldás.

2. A gerilla akciók keltette nyomás fenntartása és nyomásgyakorlás a lakosság azon rétegére, amelybe a politikai szervezet beszivárgott azzal a céllal, hogy a demoralizált kormány elfogadhatónak érezze a felkelők neutralista követeléseinek teljesítését és fegyverszünet kötését (koalícióra lépés a felkelőkkel). Kommunisták esetében ez a kormányzat leszalámizását jelentené hosszabb távon.

3. Ha a kormánnyal nem sikerül megállapodni a tüzszünetről, a katonai nyomás és a gerilla akciók okozta nyomás tovább fog növekedni, és ez arra kényszeríti a lakosság egy részét, hogy a városokban keressen menedéket az erőszak elől, tovább terhelve a kormányzatot a menekültek ellátásának problémájával. A kormányzat képességeinek csökkentése és a hangadó csoportokba való beszivárgás után már csak a megfelelő terrorista eszközöket kell alkalmazni a megfelelő célpontok ellen (politikai és katonai vezetők, a kormány külföldi támogatói stb.). (Thompson [1966] 42-44. о.) 
Ha a felkelés vereségre áll - ez akkor következik be, ha a szubverzív és a katonai vonalon is vereségeket szenved - akkor egy lépést kell tenni hátra, és béketárgyalásra kell törekedni azzal a céllal, hogy a végső vereséget elodázzák, és olyan időszakra tolják ki a fegyveres harc folytatását, amikor a politikai és katonai helyzet kedvezőbb. A legfőbb tanulság az, hogy ha a fegyveres harc kudarcba is fullad, a politikai és a szubverzív harc folytatódhat, és még győzhet is, mint Algéria esetében. (Thompson [1966] 47. о.) 


\section{FEJEZET \\ A BRIT FELKELÉSELLENES ELMÉLET FEJLŐDÉSE}

Az alábbiakban a felkelésellenes müveletek közül az ország doktrínafejlődése szempontjából jelentős csomópontokat igyekszünk bemutatni. Kiemelt figyelmet szentelünk két olyan teoretikusnak, akik jelentős gyakorlati tapasztalatok birtokában írták meg müveiket a témában. Egyikük a malájföldi háborúban részt vevő Robert Grainger Ker Thompson, aki 1966-ban jelentette meg a Defeating Communist Insurgency (A kommunista felkelés legyözése) című munkáját, a másik Frank Kitson, aki többek között kenyai és ciprusi tapasztalatok alapján írta meg a Low Intensity Operations (Alacsony intenzitású müveletek) címü, 1971-ben kiadott művét. Mindkét szerző jelentős hatással volt az amerikai doktrínaírókra is a felkelésellenes müveletek „újrafelfedezésekor”. Nehézséget jelent, hogy a hivatalos brit doktrínális iratok jelentős része a mai napig nem nyilvános.

\section{Preklasszikus szakasz (19. század vége - 1945)}

A felkelésellenes elmélet témájával a 19. század végén a brit gyarmati hadsereg tisztjei kezdtek foglalkozni. A brit hadsereg első felkelésellenes - akkoriban ún. kis háborús - kiadványa 1909-ből való. A fogalom megnevezésére a későbbiekben a birodalmi rendészet, a politikai hatalom megsegítése és az ellenforradalmi hadviselés kifejezéseket is használták, ami önmagában is jelzi a tartalom folyamatos változását és fejődését, mégpedig szerves fejlődését, mivel nem arról van szó, hogy a hatalom új kihívásokkal szembesül, hanem arról, hogy egy régi kihívás újabb és újabb megnyilvánulásaira kell válaszokat találni.

Charles Edward Callwell ezredes 1896-ban írt müvét, a Small Wars: Their Principles and Practice (Kis háborúk: Az alapelveik és gyakorlatuk) címü munkát tekintik brit részről a modern értelemben vett felkelésellenes elmélet első produktumának, szerzőjét pedig az elmélet kiemelkedő képviselőjének. Művének sajátossága, hogy igyekezett gyakorlati megoldásokat javasolni az ilyen jellegü 
konfliktusokra. ${ }^{42}$ Hangsúlyozta a konfliktusok egyedi jellegét és azt, hogy nincsenek automatikus megoldások. (Alderson [2009] 99. o.)

A birodalmi rendészet tradicionalista megközelítését képviselő mü a belbiztonsági müveletek sarokkövévé vált a War Office-ban. Callwell a pozitív (pl. erődemonstráció, a lakosság együttmüködésre ösztönzése, hazafias megmozdulások szervezése), negatív (pl. kollektív büntetés, nyers erő alkalmazása az irreguláris erőkkel szemben) és pszichológiai müveletek alkalmazását egyaránt hangsúlyozta, emellett elfogadott módszernek tekintette a nagy erők alkalmazását a lakosság feletti drasztikus irányítási eljárásokkal (lakossági/erőforrás kontroll). (Jones [2007] 5. o.)

A mü erőssége, hogy sok olyan problémáról is említést tesz, ami a mai napig gondot okoz a felkelésellenes müveletekben résztvevő erőknek, mint pl. a nem megfelelő minőségü hírszerzés, a stratégia kidolgozásának és alkalmazásának nehézségei műveleti és taktikai szinten, kommunikációs, logisztikai és biztonsági problémák. Callwell konkrét javaslatokat tesz a taktikai problémák megoldására. Intézkedéseinek célja a felkelök megfosztása a civil támogatástól. Az erő korlátozott alkalmazásának fontossága is előkerül nála, de ez messze van a később a brit megközelítés szerves részének tekintett alapelvtől. Felismerte, hogy az irreguláris konfliktusokat nem lehet egy előre megállapított fellépési sémához igazítani, és nem lehet őket a konvencionális konfliktusok mintájára lefolytatni. (Alderson [2010] 32. o.)

\section{Doktrínák a 20. század első felében}

Az 1909-es Hadműveleti harctéri szabályzat (Field Service Regulation Part I. Operations) ${ }^{43}$ egy fejezetet szentelt a vizsgált kérdéskörnek, címe a „Civilizálatlan ellenség elleni hadviselés”. Általános alapelveket határozott meg, illetve a hegyvidéki és a bozóthadviseléssel kapcsolatban adott taktikai tanácsokat.

Az 1923-ban megjelent A polgári hatalom támogatásának kötelességei (Duties in Aid of the Civil Power) címü doktrína kiadásának célja az volt, hogy a katonai és polgári jogot összekösse az olyan erőszakos megmozdulások kapcsán, amelyekkel a polgári kormányzat egyedül nem képes megbirkózni. Bevezetése a szakszervezeti

\footnotetext{
${ }^{42}$ Callwell a kis háborúkról azt írja, hogy ,a ,,kis háború” kifejezésnek nincs semmilyen lényegi kapcsolata a hadjárat kivitelezésének méretével, egyszerüen arra szolgál, hogy alkalmasabb megjelölés hiányában a reguláris erők irreguláris vagy relatíve irreguláris erőkkel szembeni müveleteit jelölje." (Callwell [1906] 21. o.)

${ }^{43}$ General Staff, Field Service Regulations Part I: Operations, War Office, 1909. http://ia600300.us.archive.org/17/items/pt1 fieldservicer00greauoft/pt1 fieldservicer00greauoft.pdf
} 
megmozdulások ellen irányult, nem potenciális kommunista szubverziós kísérletek ellen. A kiadvány azért nagyon fontos, mert megerősítette a minimális erőalkalmazás kritériumát, és ez az igény innentől minden ilyen jellegü müveletnél megjelenik. Az alapelv az 1912-es Katonai Törvényi Kézikönyvre (Manual of Military Law) vezethetö vissza, (Alderson [2009] 100. o.) amely zavargást és lázadást különböztetett meg, és a szükséges erő alkalmazását engedélyezte a rend helyreállítására. (Alderson [2010] 3031. o.) Ez a szabályozás annyira tartósnak bizonyult, hogy csak 1937-ben frissítették. (Ministry of Defence [2009] CS 1-3. o.)

Az elv megerősítését Dyer tábornoknak az indiai Amritsarban, 1919. április 3-án történt fellépése tette szükségessé. A tábornok a jogi kereteket úgy értelmezte, hogy egy tízezer fős, fegyvertelenek részvételével történő tüntetés kimeríti a lázadás fogalmát, és tüzparancsot adott: 379-en meghaltak és több mint ezren megsebesültek. A vérontást követő felháborodás következtében rendkívüli állapotot kellett bevezetni, és az indiai nacionalista politikai életben döntő fordulat következett be miatta. (Alderson [2010] 31. o.) Az elv elfogadása nem jelenti, hogy azt a brit harcoló erök minden konfliktusban betartották, de az erő alkalmazásának jogi keretek között tartása az ilyen jellegü konfliktusok során a brit megközelítés máig fontos eleme.

A britek a két világháború között komolyan számoltak egy egyenrangú ellenféllel való összecsapás lehetőségével, és ezt doktrínális dokumentumaik is tükrözték. Példa erre az 1929-es Harctéri hadmüveleti szabályzat (Field Service Regulation), amely a konvencionális háborúnak szentelte tartalma jelentős hányadát, és az egyéb konfliktusokra a vele kapcsolatos alapelvek módosított alkalmazását javasolta.

A kiképzésre vonatkozóan négy tág kategória került benne meghatározásra:

- birodalmi rendészet

- kisebb expedíciók

- nagyobb expedíciók

- általános háború

Az 1920-as évek első felében az Európán kívüli hadszínterek voltak az érdeklődés homlokterében, a harmincas évek első felében az európai háborúra való felkészülés került a középpontba - amihez 1939-ig nem volt politikai támogatás. (French [2009] 3639. o.) Konvencionális háborúra vonatkozó doktrínát 1929 előtt is publikáltak, 1920-ban és 1924-ben is. Az alacsonyabb intenzitású konfliktusok elméletével való foglalkozás az 
utóbbiakkal párhuzamosan haladt: a polgári hatalom megsegítésére kiadott doktrínát (Duties in Aid of Civil Power, 1923) fentebb érintettük.

1932-ben felső kezdeményezésre különbizottság alakult az első világháború tanulságainak doktrínális rögzítésére. (French [2009] 39. o.) Nem párosult ehhez egy kellően kidolgozott rendszer a hadsereg képzésének egységesítésére, így a képzés továbbra is elaprózott maradt. (French [2009] 41. o.) A gyarmati kötelezettségek azonban olyan méretűvé váltak, hogy sokszor nem volt lehetséges az egységszintü képzés végrehajtása sem. (French [2009] 43. o.)

\section{Az ír függetlenségi háború (1919-1921) szerepe}

Annak ellenére, hogy a britek korábban már találkoztak a felkelések különböző aspektusaival, nem tanulmányozták őket mélyebben. A brit hadsereget az 1910-es évek végén egyfajta antiintellektuális hullám uralta, amikor jellemzően nem alkalmazkodtak a konfliktus körülményeihez. 1919-ben, amikor az írországi események kezdetüket vették, a régi jól bevált módszereket alkalmazták. Ezek közé tartozott a kollektív büntetés intézménye és más, mai mércével elfogadhatatlan eljárások sora. A politikai dimenzió összességében eléggé elhanyagolt volt. A hadsereg vezetése nem figyelt az olyan tisztekre, mint $T$. E. Lawrence, akinek az arab felkelők támogatása során szerzett tapasztalatai fontosak lettek volna a konfliktus megértéséhez.

Az elszenvedett kudarcra reflektálva 1922-ben a War Office kiadta az Ír feljegyzés (Irish Record) című kiadványt, amely az írországi felkelésellenes mủveleteket írta le a föparancsnokság és a törzstisztek számára. Ezek kapcsán kritizálta a katonai vezetést, amiért a hírszerzést kizárólag a hírszerző szolgálat feladatának tekintette. Megállapította, hogy az alkalmazott taktikák egy része (mint a blokkházak ${ }^{44}$ bevett alkalmazása) inkább elriasztotta, semmint segítette az együttmüködni kívánó helyieket, aláásva ezzel a politikai célokat. Javasolta a helyi lojalistákból és progresszívekből szervezendő terroristaellenes önvédelmi erő létrehozását, nem utolsósorban az információáramlás javítása érdekében. A dokumentum tizenöt általános elvet határozott meg a lázadások leverésére. A hadsereg vezetése azonban nem feltételezte, hogy az Írországban tapasztaltak később általánosan várható jelenségek lesznek, inkább egyfajta anomáliának tekintette a konfliktust, és ennek megfelelöen viszonyult a javaslatokhoz. (Jones [2007] 6-8. o.)

\footnotetext{
${ }^{44}$ Egy kis, megerösített épületet jelent, ahonnan kiindulva a katonai egységek müködtek.
} 


\section{A két világháború közötti brit tevékenység a gyarmatokon}

A felkelésellenes müveletekre vonatkozó tanulási folyamat a brit birodalom méretéből adódóan nem lehetett egységes. A legtöbb tapasztalat azokon a helyeken generálódott, amelyeken aktív felkelések folytak, vagyis föként a távol-keleti gyarmatokon.

Az egyik kiemelendő doktrínális jellegü dokumentum az India északnyugati határán végrehajtott müveletek kézikönyve (Manual of Operations in the North-West Frontier of India) volt, amit 1925-ben adtak ki. Általánosságban véve tradicionális megközelítésü volt, újdonságot csak a légierő alkalmazásának módjára tett javaslat jelentett. Egészében véve a húszas években nem volt átfogó kísérlet arra, hogy a belbiztonsági műveletek tanulságait megpróbálják összefoglalni. (Jones [2007] 8-9. o.)

Az ún. légi rendészet, amit a költségcsökkentés érdekében hoztak létre, és ami a RAF alternatívája volt a drága helyőrségek kiváltására, az iraki konfliktus (1922-1932) idején sikeresen müködött. Ott megfelelő felhatalmazás, felszerelés és személyi állomány állt rendelkezésre, de hamar kiderült, hogy sokkal hasznosabb, ha a légierőt a szárazföldi erőkkel összhangban vetik be, ezért a későbbiekben ez a megközelítés teljes mértékben elhalt. (Alderson [2010] 32. o.)

A harmincas években a brit hadseregnek a Távol-Keleten volt sok feladata. 19301936 között a szubkontinensen segítette a peshawari, a burmai és a bengáliai rendörséget. Ez sokféle konfliktusban való részvételt jelentett: banditizmus, kezdetleges felkelés és lázadás elleni fellépés, gerillaháború és a konvencionális hadviselés egyaránt terítéken volt. A koordináció fontossága hamar előtérbe került, így már 1931-ben közös katonai-rendőri-adminisztrációs bizottság (triumvirátus) jött létre, amely biztonsági tervet készített, majd hajtott végre. 1932 újabb változást hozott: a katonai egységek feladata lett a lakosság és az adószedés védelme a műveleti területükön. Ennek érdekében bizonytalan idejü őrjáratokat indítottak, több ezer embert telepítettek táborokba, ahol igazolvánnyal látták el őket. Ezen túl polgári-katonai rendkívüli bizottságokat is létrehoztak, valamint egy polgárőrséget (Citizen Guard), feltételezhetően az írországi tapasztalatok alapján. 1933-ban jóléti reformokat vezettek be a lakossági támogatás megszerzése érdekében. (Jones [2007] 10. o.)

Palesztin mandátumterületen rendszeresen voltak kisebb-nagyobb intenzitású konfliktusok különböző csoportok között. Az 1936-1939 közötti, arab felkelésként ismert konfliktus két nagyobb szakaszra osztható: 1936-1937-ben gyengén szervezett 
erök (terroristák, propagandisták, zavargók és a gerilla taktikákban kevéssé járatos irregulárisok) ellen a szokott módszerekkel léptek fel, és úgy tünt, hogy a konfliktus 1937-re kifullad. 1937 második felében azonban új, veszélyesebb felkelés kezdett kibontakozni modern gerilla taktikákat, propagandát és terrorista eljárást alkalmazva. A belső megosztottság és a lakossági támogatás hiánya miatt nem lehetett sikeres, emellett katonailag is elégtelen volt a felkelők teljesítménye.

A felkelés kapcsán újdonság volt egy királyi bizottság létrehozása, ami politikai kezdeményezésre jött létre. Újítás a helyiekből szervezett különleges rendeltetésű biztonsági erő létrehozása is, ami Orde Wingate őrnagy nevéhez kapcsolható, aki 1938ban életre hívta a Különleges Éjszakai Rajokat (Special Night Squads, SNS) ${ }^{45}$ gerillaellenes erőként, éjszakai rajtaütések, lesállások és pszeudo gerilla müveletek ${ }^{46}$ végrehajtására. Az egység nem nyerte el a brit katonai vezetés tetszését, 1939-ben kínzási vádak miatt fel is oszlatták. Az arab felkelést egészében véve kivételesnek tekintették. (Jones [2007] 13. o.)

\section{Brit nem konvencionális tevékenység a második világháború alatt}

A második világháború a brit hadsereg és hírszerzés számára nemcsak a konvencionális háború előtérbe kerülését jelentette, hanem a nem konvencionális hadviseléssel való kísérletezést is, bár az utóbbi sokszor csak civil kezdeményezésre indulhatott meg.

1939-ben a Katonai Hírszerzési Igazgatóság (Directorate of Military Intelligence, DMI) kutatótestületet állított fel Colin Gubbins, Gerald Templer és J. C. F. Holland részvételével. Mindannyian részt vettek különböző konfliktusokban, rendelkeztek nem konvencionális jellegü konfliktusokban szerzett tapasztalatokkal, és sokféle gerilla erő tanulmányozása után kommandó jellegü akciók végrehajtását javasolták. (A vezérkari főnök mellett dolgozó Dudley Clarke ezredes 1940-ben hasonló eredményre jutott, amikor kisméretű part menti rajtaütéseket javasolt.) A politikai vezetés elfogadta a javaslatukat, Alan Brooke vezérkari főnök viszont nem, és a kutatótestületet végül 1943-ban feloszlatták.

\footnotetext{
${ }^{45}$ Az SNS a brit hadsereg katonáiból (40 fö) és zsidó önkéntesekből állt (75 fö). Creveld, Martin van: The Sword and the Olive: A Critical History of the Israeli Defense Force, 39-40. o.

${ }^{46}$ A pszeudo gerilla vagy más néven álgerilla müveletek olyan csoportok szervezését jelentik, amelyeket felderítés vagy az ellenséges csoportok megsemmisítése céljával hoznak létre
} 
A szükség azonban úgy hozta, hogy számos nem konvencionális hadviselést folytató szervezet került felállításra a második világháború alatt. Ezek közül a legjelentősebbnek a Különleges Műveleti Szolgálat (Special Operations Executive, SOE) 1942-es felállítása mondható, amelynek fő feladata szabotázsakciók végrehajtása volt az ellenséges hátországban, de számos semleges országban is jelen volt.

A hadsereg kötelékében is tettek kísérleteket új egységek felállítására. A különleges alakulatok ilyen egységei közt a leghíresebb az SAS (Különleges Légi Szolgálat, Special Air Service) és az SBS (Különleges Tengeri Szolgálat, Special Boat Service). Orde Wingate, aki főszerepet játszott az SNS szervezésében, több ilyen egység felállításában is részt vett. A legnagyobb hatása ennek a folyamatnak a távol-keleti brit erőkre volt, ahol 1945-re általánosan elfogadottá vált az irreguláris gondolkodás. (Jones [2007] 14-15. о.)

A brit hadsereg módszerei nem voltak alkalmasak arra, hogy Francia Indokínában szétzilálják az irreguláris erőket, de Irakban és Burmában sikeresek voltak. Ez a hagyományos megközelítés sikere volt, amely az ellenség hibás taktikájának felismerésén alapult. Brit erők a Holland Antillákon is harcoltak a felkelők ellen, és heves harcok után le is győzték őket. Ezek a sikerek a konzervatívokat meggyőzték arról, hogy nem kell változtatni a bevett módszereken.

A második világháború végével a politikai hadviselés szakértői visszatértek a civil életbe, és ezzel sok újítás elveszett. Az SOE feloszlatásra került, de szinte minden téren komoly leépítések voltak. A közhangulat az elnyomás ellen fordult, a katonai elit részéről aktív ellenállás mutatkozott a nem konvencionális egységekkel szemben (az SOE-ből sokan kerültek az MI6-hez, kevesebben az MI5-hoz). Ugyanakkor létrehoztak egy klubot a volt SOE-tagoknak annak érdekében, hogy a képességeiket később használni lehessen olyan problémás helyeken, mint Görögország. Az SAS-t is feloszlatták, de az is igyekezett megtartani az integritását. 1945-ben az SAS-ben készült egy tanulmány a nem konvencionális erők jövőbeni bevethetőségéröl, amely az ezred számára több lehetőséget látott polgárháborúkba való beavatkozásra. (Jones [2007] 1718. o.)

\section{A témában megjelent fontosabb müvek}

Korát jóval megelőző, fontos cikket írt B. C. Denning örnagy, ami a brit hadsereg egyik kiadványában, a The Army Quarterly-ben jelent meg 1927-ben, A gerilla 
hadviselés modern problémái címmel. A szerző a felkelések okainak megszüntetése mellett érvelt, bár ezt a bevett gyakorlattal párosította. (Ministry of Defence [2009] CS 1-2. o.) Ez a megközelítés ekkor még nem kapott különösebb figyelmet, és csak a második világháború után nyert teret.

Sir Charles Gwynn vezérőrnagy jelentős mértékben járult hozzá a felkelésellenes elmélet továbbfejlődéséhez. A katonai akadémia parancsnoka volt 1926-1930 között, visszavonulása után írta meg fö müvét, az 1934-ben megjelent Birodalmi rendészet (Imperial Policing) címü könyvet. Ugyanebben az évben megjelent a War Office kiadásában a Feljegyzések a birodalmi rendészetröl (Notes on Imperial Policing) címü kiadvány, amelynek valószínűleg szintén Gwynn a szerzője. (Alderson [2009] 103. o.) Ez megerősítette a Duties in Aid rendelkezéseit, amennyiben a jelenléttel és a lakosság kontrolljával megszerzett információk segítségével végrehajtott letartóztatások és razziák fontosságát hangsúlyozta. Az Irish Record mintájára a lojalisták védelmét és a terephez és az ellenséghez való alkalmazkodást javasolta. Az utóbbin kisméretü egységek bevetését értette a gerilla erők ellen. Ez előrelépést jelentett a korábbiakhoz képest. (Jones [2007] 11. o.)

Gwynn könyve hivatalosan nem volt doktrína, de a gyakorlatban annak számított. Alapelvei fontosak:

- A politikát a polgári kormány határozza meg, és azt végre kell hajtani a megfogalmazott elvekhez ragaszkodva.

- Az alkalmazandó erő a mindenkori helyzethez igazodva minimális legyen.

- Erőteljes és jól időzített fellépés kell ahhoz, hogy további rendbontásokat megakadályozzanak.

- Szoros együttmüködés kell a polgári és a katonai hatóságok között, természetesen az előbbi vezetésével. (Alderson [2010] 33. o.)

Müvének jelentős érdeme, hogy az erő alkalmazásának paradoxonjait is tárgyalja, mondván, hogy egy békés polgári kormány erőszakos támogatásánál ez elkerülhetetlen. Rámutat, hogy a túlzott erő alkalmazása elidegenítheti a megnyerni kívánt rétegeket, míg a minimális erő alkalmazását a gyengeség jelének lehet felfogni. (Alderson [2009] 102. o.) A mü kilenc, a későbbi kiadásokban tizenegy 1919-1931 közötti brit felkelésellenes mủveletet elemez. ${ }^{47}$ Javasolja a tervezési hármas (katonai-rendőri-civil)

\footnotetext{
${ }^{47}$ Ezek: Amritsar 1919, Egyiptom 1919, Moplah lázadás 1921, Chanak 1922, Khartum 1924, a Shanghai védelmi erő 1927, Palesztína 1929, Peshawar körzet 1930, burmai lázadás 1930-32, Ciprus 1931,
} 
vezetés kialakítását és egy katona kinevezését a harcok vezetésére szükségállapoti vagy rendkívüli törvények alatt, illetve hangsúlyozza, hogy semmilyen módszert sem szabad elhanyagolni, ami sikerre vezethet, beleértve a propagandát. (Jones [2007] 12. o.)

A Feljegyzések a birodalmi rendészetről című kiadvány annyiban egészíti ki a fentieket, hogy a felkelés jelentette komplex politikai helyzetet egyértelmübben fogalmazza meg, a zavargásokat szélesebb politikai problémák jelének mondja, és elismeri az ilyen körülmények közötti biztonságfenntartás (vagyis a felkelök elleni hatékony fellépés) és az emberek életének megóvása közötti feszültséget, ezért a normál életkörülmények biztosítását és az erőszakért felelősek elnyomását határozza meg a hadsereg feladataként. (Alderson [2009] 103. o.)

H. J. Simson örnagy A brit uralom és az 1937-es lázadás (British Rule and Rebellion of 1937) címü munkája mára a kevéssé ismert müvek sorába tartozik, de fontos a benne megfogalmazott kritikák miatt. A szerző föként a hadsereg felkelésekhez való hozzáállását kritizálta. Amellett érvelt, hogy a felkelők új módszerei ellen nemcsak a taktikai tanulságokat kell levonni, hanem komolyabb, átfogóbb eljárásokat kell kifejleszteni. A burmai tapasztalatok mintájára javasolta támogatni a propagandát, a hatékonyabb lakosságirányítási modelleket, a háromszereplős tervezést és a közös parancsnok kinevezését. (Jones [2007] 12. o.)

\section{Klasszikus szakasz: Brit felkelésellenes müveletek és doktrínák a második világháború után}

A második világháború végével a prioritások ismét újraértékelés előtt álltak. A brit hadsereg a németországi szerepvállalással, a fokozódó szovjet fenyegetéssel, valamint a fokozódó gyarmati problémákkal hasonló helyzetben találta magát, mint a két világháború között volt. Míg a rajnai brit hadsereg (British Army of the Rhine, BAOR), amely az aktív állomány jelentős hányadát foglalta magában, a hidegháború alatt egy teljesen konvencionális háborúra készült, addig Palesztinában, Malájföldön és még számos helyszínen ismét a felkelésellenes műveletek végrehajtása került előtérbe. 


\section{Doktrínák (1949-1995)}

1949-ben a korábbi tapasztalatokkal összhangban született meg a Birodalmi rendészet és a civil hatalom megsegitésének kötelességei (Imperial Policing and Duties in Aid of the Civil Power, 1949) címü kiadvány, amely elismerte a változó helyzetet a második világháború után, de nem adott aktuális stratégiai kontextust a brit birodalom szempontjából. Hangsúlyos volt benne a külső támogatást élvező ellenállási mozgalmak jelentette veszély, és a kommunista szubverzív és fegyveres fellépés fázisai is megjelentek benne a hozzájuk igazított fokozatos fellépéssel egyetemben, hangsúlyozva a polgári és katonai szervek együttmüködését. Másfelöl viszont nem erösítette meg a Feljegyzések a birodalmi rendészetről címü kiadvány szélesebb politikai kontextusra vonatkozó megállapításait. (Alderson [2009] 104. o.)

A béke megtartása (A polgári hatalom támogatásának kötelessége) (Keeping the Peace (Duties in Support of the Civil Power)) címü, 1957-ben megjelent doktrína folytatta az Imperial Policing and Duties in Aid of the Civil Powerben, elöször 1923ban a fegyveres erőkkel kapcsolatban megfogalmazott elvárások kifejtését a rend helyreállítására, a politikai hatalom támogatására és a törvénytelen megmozdulások leverésére vonatkozóan. Fontos újdonságokat is tartalmazott, illetve továbbfejlesztette az 1949-es dokumentum egyes megállapításait. Ezek közül az egyik legfontosabb a politikailag motivált, külföldről támogatott felkelésekre vonatkozott, és malájföldi tapasztalatok alapján részletezte a polgári és a katonai erők feladatait. Ebben a dokumentumban fogalmazódott meg a rugalmasság igénye, amelynek megfelelően formalizálta a régióban történő specifikus képzést is.

A dokumentum bevezette a ,rend fenntartása a tengerentúli gyarmatokon” funkciót, és leszögezte, hogy a rend helyreállítása a kormányzat feladata, ezt pedig a hadsereg, a rendőrség és a polgári szervek koordinált együttmüködésével kell elérni. A malájföldi példára támaszkodva műveleti igazgató kinevezését vagy haditanács létrehozását javasolta. Taktikai megoldásokat is tartalmazott, többek között az olajfolttaktikát is. A lakosság és a felkelők szétválasztásának koncepciója is megtalálható benne, azonban a fellépés szakaszait nem határozta meg. A dokumentum hangsúlyt helyezett a pszichológiai dimenzióra is, és hatékony információs szolgálat létrehozására és egyéb taktikai megoldásokra tett javaslatot annak érdekében, hogy az ellenséges agitáció, illetve szubverzív propaganda ellen fel lehessen lépni. 
A kormányzatot felölelő, koordinált egyesített terv létrehozását javasolta, hangsúlyozta az alkalmazkodás fontosságát a taktikai szinten, jelentős figyelmet fordított a pszichológiai elemekre, és a lakosság és a felkelők egymástól való elválasztását tüzte ki elsődleges célként. Nagymértékben a malájföldi tapasztalatok intézményesítését jelentette a jövő konfliktusaira nézve. Alkalmazásának fő problémája abban állt, hogy polgári kormányzatnak kellett engedélyezni, amire az gyakran nem volt fogadókész. (Alderson [2009] 108-111. o.)

A béke megtartása (A felkelök elválasztása a támogatóiktól) (Keeping the PeaceSeparating Insurgents from Their Support) címü, 1963-ban megjelent doktrína beépítette a malájföldi, kenyai és ciprusi tapasztalatokat. A lakosságközpontú megközelítést helyezte elötérbe, és nagy jelentőséget tulajdonított a felkelöinfrastruktúra elpusztításának. Összességében a katonai és politikai szerepek pontosabb elválasztásában jelentős elörelépést tett a korábbi kiadáshoz képest. (Alderson [2009] 111-112. o.)

1969-ben új doktrína született Ellenforradalmi müveletek (Counter-Revolutionary Operations) címmel, mégpedig a brit hadsereg addigi legteljesebb doktrínája a felkelések leverésére vonatkozóan. Számos újdonságot hozott, emellett igyekezett az addig használt fogalmakat kiegészíteni, továbbfejleszteni, összekapcsolni, vagy egyszerüen definiálni, hogy csökkentse a káoszt ezen a téren. A felkelés fogalma ebben a kiadványban került átfogóan definiálásra, és a katonai hozzájáruláson túl gazdasági, szociális és politikai feladatokat is meghatározott a felkelésellenes tevékenység részeként. A szubverzív szervezet elpusztítása és a kormányzati rendszer helyreállítása kapta az elsődleges szerepet a felkelők megölése helyett, a politikai változás pedig előfeltételként szerepelt a sikerhez.

Öt prioritást határozott meg:

- Nemzeti szintü terv kialakítása - politikai és gazdasági reformok, hatékony koordináció a biztonsági szervek között stb.

- Jó kormányzás - a lakosság nagy részének törekvéseivel összhangban lévő kormányzás.

- Lakossági támogatás - ennek megszerzése, illetve visszaszerzése a fö cél a fentebbek segítségével.

- Elfogulatlan igazságszolgáltatás létrehozása.

- Hatékony biztonsági erők kialakítása. 
További újdonságai közé tartozott, hogy definiálta az olajfolttaktikát és a „szíveklelkek" megközelítést, továbbá részletes taktikai iránymutatásokkal szolgált a belbiztonsági (polgári engedetlenség, zavargás, terrorista tevékenység) és felkelésellenes (vidéki szubverzív és gerilla tevékenység) műveletekkel kapcsolatban. (Alderson [2009] 112-116. o.)

\section{Malájföld (1948-1960)}

A malájföldi konfliktus azért fontos a téma szempontjából, mert talán máig ez a legtöbbször említett és elemzett sikeres felkelésellenes konfliktus, amely - elsősorban Robert Thompsonnak köszönhetően - széles körben lett ismert.

A malájföldi konfliktus a britek szempontjából nem kevés hátránnyal indult, pl. a békeidős berendezkedésnek megfelelően a rendőrparancsnok volt az általános parancsnok a felkelők elleni harcban (vagyis a hadsereg neki volt alárendelve), rossz volt a hírszerzés, nem volt megfelelő a koordináció, és ezek miatt nem voltak eredmények. További probléma volt, hogy a brit hadsereg, amely a második világháború alatt a Távol-Keleten rendkívül sok tapasztalatra tett szert a dzsungelekben vívott harcokban, az ötvenes évek elejére ezt a tudást intézményi szinten gyakorlatilag teljes mértékben elveszítette, ezért a bevetésre került csapatoknak rögtönözniük kellett. Ezt a hibát sok idő, energia és áldozat árán volt csak képes a brit hadsereg kompenzálni nem egy szervezet és intézmény létrehozásán keresztül, melyek közül talán a legfontosabb a Dzsungel Hadviselési Iskola (Jungle Warfare School, JWS) (Alderson [2009] 106. o.) beindítása és a Különleges Légi Szolgálat (Special Air Service, SAS) nyílt újjászervezése. (Jones [2007] 114-115. o.)

A kiinduló helyzet azonban jelentős „beépített” előnyöket is tartalmazott, ahogyan ezt Robert Thompson megírta. Malájföld ideális volt a védelem szempontjából, mivel a szárazföldi határa mindössze 150 mérföld volt, és csak egy - a brit hatóságokkal együttmüködő - állammal volt határos. Hiányzott viszont a helyiekből álló, politikai vezetés ellátására képes csoport, ezt létre kellett hozni. Malájföld esetében fontos volt, hogy a brit és maláj erőknek elsősorban kínai felkelőkkel kellett szembenézniük, akik a lakosság kisebbségét adták. Ez az etnikai dimenzió előny és hátrány is volt, mivel a konfliktus felvethette a sino-maláj rasszizmus kérdését, ami komoly problémává válhatott volna. Az önálló maláj erők kezdetben mindössze két zászlóaljjal rendelkeztek - amit kilencre növeltek a konfliktus során -, így Malájföldön a brit nemzetközösségi 
erőknek jutott a föszerep. A csúcson, 1951-ben kb. 20000 fövel voltak jelen Malájföldön. Az egyéb brit támogatás nem volt jelentős.

A felkelők elsősorban a dekolonizációt és az antiimperialista eszméket használták a lakosság mozgósítására. Mellettük a földreform, a kizsákmányolás, a kisebbségek regionális autonómiája és a bevándorolt népek egyenjogúsága kapott még szerepet. Sok társadalmi törésvonal is volt, amelyeket megpróbálhattak a javukra fordítani, ilyenek pl. a fiatal - öreg, a progresszív - tradicionalista, az etnikai - vallási és a helyi kapitalista globális kapitalista ellentétpárokkal leírhatók. (Thompson [1966] 19-21. o.)

1950-ben fordulat következett be, és az ezt követő reformok jelentős hatással voltak az alakuló brit felkelésellenes megközelítésre. Ekkor hozták létre a müveleti igazgatói (director of operations) pozíciót, amit elsőként Sir Harold Briggs tábornok töltött be. Ez közös parancsnokság alá helyezte a Malájföldön müködő rendőrséget, a szárazföldi, légi és haditengerészeti erőket, új szintre emelve a civil-katonai együttmüködést. Briggs tábornok egy bizottsági rendszert hozott létre minden szinten, és hosszú távú tervezésre rendezkedett be, felismerve, hogy a többségében a kínai etnikumhoz tartozó felkelőket el kell választani a hátországukként szolgáló kínai közösségektől. Vezetésével megalkották a róla elnevezett Briggs Tervet (Briggs Plan), amelyben jelentős szerepet kaptak a ma is ismert felkelésellenes alapelvek: a lakosság bizalmának és támogatásának a biztosítása, a kormányzás minőségének javítása és a felkelés politikai okainak semlegesítése. (Alderson [2009] 106-107. o.)

Fontos változást hozott személyi téren, hogy 1952-ben megölték Sir Henry Gurney királyi föbiztost. A helyére Gerald Templer ${ }^{48}$ került, aki nagy lendülettel vetette bele magát a felkelésellenes harcba, mégpedig az elődjéhez képest szélesebb jogkörrel: amellett, hogy főbiztos volt, a müveleti igazgató feladatát is ellátta. Templer azzal az utasítással érkezett Malájföldre, hogy Nagy-Britannia függetlenséget fog biztosítani a területnek, ehhez azonban a felkelést le kell vernie. (Nagl [2005] 88. o.)

Templer kezdeményezésére született meg a konfliktus legérdekesebb doktrínális dokumentuma, a The Conduct of Anti-Terrorist Operations in Malaya (A terroristaellenes müveletek végrehajtása Malájföldön, ATOM). Az 1952-ben született dokumentum szerzője Walter Walker alezredes volt, akinek a Dzsungel Hadviselési Iskola vezetőjeként jó rálátása volt a brit oldal hiányosságaira. Az ATOM így egyfajta

\footnotetext{
48 Templer korábban hadosztályparancsnok, a katonai hírszerzés vezetője, szolgált a vezérkari főnök helyetteseként és a második világháborúban a németországi brit megszállási zóna vezetőjeként is. (Nagl [2005] 87-88. o.)
} 
hadszíntéri doktrína, amely a Dzsungel Hadviselési Iskola tapasztalatait alapul véve foglalta össze a konfliktus sajátosságait és tanulságait a felkelésről, a rendkívüli törvényekről, a kiképzésről, valamint a dzsungelműveletekről és -taktikákról. (Alderson [2009] 106. o.)

Az ATOM az átfogó jellegével, a fenyegetés, a stratégia, a civil és a katonai fellépés, a jogi megfontolások stb. összefogásával fontos kiinduló alap lett a későbbi doktrínaíráshoz. (Alderson [2009] 108. o.) Alapja lett az 1957-es doktrínának (Keeping the Peace (Duties in Support of the Civil Power)), és hatott más konfliktusban is a megközelítésre, elismerve a konfliktusspecifikus doktrína létjogosultságát. Kenyában az ATOM mintájára született meg a Handbook on Anti-Mau Mau Operations (Kézikönyv a Mau-Mau ellenes müveletekhez), melynek anyagát a Kelet-afrikai Katonai Iskola (East Africa Battle School) adta. (Alderson [2010] 37. o.)

\section{3. Észak-Írország}

Bár jelentős áttörések történek doktrínális téren, a Counter-Revolutionary Operations nem a megfelelő doktrína volt az észak-írországi alkalmazásra. A brit hadsereg elég gyorsan szembesült a ténnyel, hogy ami a gyarmatokon elfogadhatónak minősült, az politikailag tarthatatlan Észak-Írországban. A leghírhedtebb melléfogás talán a Véres Vasárnap (1972. 01. 02.) volt, amely megmutatta, hogy a hadsereg nincs megfelelően felkészülve a tömegtüntetések kezelésére. A halálos áldozatok a politikai helyzetet otthon és Észak-Írországban is tovább bonyolították. Fontos kiemelni a hibák sorából az elfogult rendőri erő kérdés nélküli támogatását, a rossz hírszerzést és a nagy egységekkel végrehajtott mủveletek sorát stb., amelyek arra utalnak, hogy még a korábbi müveletek tanulságait sem megfelelően alkalmazták. Ezért elkerülhetetlen volt jelentős változtatások végrehajtása a brit hadsereg megközelítésében.

A brit hadsereg Észak-Írországban a politikai hatalom segítőjeként lépett fel (a hivatalos kifejezéssel Military Assistance to the Civil Power, MACP), ennek megfelelően a rendőrségé volt a vezető szerep, a hadsereg csak támogatást nyújtott. A koordinációs problémák orvoslására bizottságot alakítottak, amely több változtatást is eszközölt a reguláris hadsereg és a különleges erők, valamint a hírszerző szervezetek együttműködésének javítása érdekében. Külön képzési rendszert hoztak létre 1972-től

az Észak-Írországban szolgálatot teljesítő egységek képzésére. Ezek az Észak-írországi Kiképző és Tanácsadó Csoport (Northern Ireland Training and Advisory Team, NITAT) 
és a Biztonsági Müveleti Kiképző és Tanácsadó Csoport (Security Operations Training and Advisory Team, SOTAT). Érdekesség, hogy utóbbi Németországban müködött, mivel az egységek egy része a BAOR kötelékéböl lett átcsoportosítva. (Alderson [2009] 123-125. о.)

Kidolgoztak egy Észak-Írországra vonatkozó doktrínajellegű kiadványt, ami az Észak-írországi Hatályos Műveleti Eljárások (Northern Ireland Standing Operating Procedures, NISOPs) címet kapta. További eredmény volt a Counter-Revolutionary Operations kézikönyv 1977-es kiadásának megjelenése. Mivel a polgári hatalom megsegítésére vettek részt a konfliktusban, maga a doktrína nem tett említést ÉszakÍrországról.

Az 1980-as évektől három fő céljuk volt a műveleteknek: a lakosság bizalmának biztosítsa, a zavargásoktól és terrorakcióktól való elrettentés és a terroristák kimerítése. Az alábbi müveleti formákat alkalmazták:

- titkos (covert)

- keret (framework): a támogató infrastruktúra és a látható jelenlét (ezzel a támadásoktól való elrettentés) volt a lényege

- létszámemelés (surge): megerősített keretmüveletek, amelyek mobil (elsősorban helikopteres) egységek, tartalékok bevetését jelentették olyan eseményeknél, amelyek különösen feszültek voltak (Alderson [2010] 3738. о.)

Sor került különleges egységek felállítására is, melyek közül az egyik egy katonai-hírszerzési egység volt. ${ }^{49}$

\section{Felkelésellenes alapmúvek}

\section{Robert Grainger Ker Thompson: A kommunista felkelés legyőzése}

Robert Thompson közigazgatási tisztviselöként vett részt a malájföldi konfliktusban, majd tanácsadó volt Dél-Vietnamban. Könyvében a malájföldi felkelés tapasztalataira építve vont le következtetéseket, illetve párhuzamokat és eltéréseket állapított meg az akkor még folyamatban lévő vietnami háborúval. Thompson a műve elején két kérdését fogalmazott meg, melyek a mai napig relevánsak:

\footnotetext{
${ }^{49}$ Lásd bővebben: (Rennie [2009])
} 
- „Hogyan képesek a kommunista erők túlélni és akár felülkerekedéssel fenyegetni a konvencionális erőket, amelyeket olyan országok támogatnak, melyek hatalmuk, gazdagságuk és jó szándékuk okán látszólag legyőzhetetlenek;

- Miként lehet öket legyözni hatalmas emberi, pénzügyi, anyagi és időbeli befektetés nélkül, valamint a konvencionális háború veszélyének elkerülésével?" (Thompson [1966] 13. o.)

Az alábbiakban könyvének a felkelésellenes küzdelemmel foglalkozó részeit foglaljuk össze.

Thompson a felkelésellenes küzdelem sikeres megvívásának érdekében öt alapelvet és négy müveleti elvet fektetett le, rendszerbe foglalva a célokat és a teendőket.

Az öt alapelv a következő:

- Egyértelmü politikai célt kell kialakitani - olyan szabad, független ország létrehozása és fenntartása tekinthető elfogadható célnak, amely politikailag és gazdaságilag stabil és életképes. ${ }^{50}$

- A kormányzatnak a törvényekkel összhangban kell müködni;

- A kormányzatnak készíteni kell egy általános tervet - amelynek nemcsak a katonai és biztonsági intézkedéseket kell tartalmaznia, hanem a politikai, gazdasági, szociális, adminisztratív, ${ }^{51}$ rendőri és egyéb intézkedéseket is, amiket a felkeléssel szemben alkalmazni kíván.

- A kormányzatnak a politikai szubverzió legyözésére kell koncentrálnia, nem a gerilla mozgalomra - amíg a politikai szervezetet nem sikerül felszámolni, addig a gerilla egységek is müködni fognak. A politikai szervezet felszámolásával az utánpótlás, a hírszerzés, az újonclétszám folyamatosan csökken, majd megszünik.

${ }^{50}$ A fejlődő országokban fontos probléma, hogy a kormány mindenképpen maximális győzelemre törekszik, akár csalás árán is - mivel a lojális ellenzék fogalma általában ismeretlen -, és olyan erők is bekerülhetnek a törvényhozásba, amelyek annak az eröszakos megdöntése mellett vannak. Az ellenzék háttérbe szorítása viszont szükségszerüen összeesküvés-elméletek kialakulásához vezet. A nyugati mintájú demokrácia az intézményrendszer magas fokú fejlettségét igényli (beleértve az írt és íratlan szabályok kialakulását és elfogadását is). Egy döntően mezőgazdasági társadalom esetében a parasztsággal nehéz elfogadtatni a központi kormány szerepét, mivel általában jellemző a gyanakvás, és jelentős az igény a kormánytól való elszigeteltségre. Ezért a demokrácia nem lehet a kommunizmus ideológiai ellenpontja. (Thompson [1966] 67-68. o.)

${ }^{51}$ Javaslatai nem egyszerüen a taktikai szintre vonatkoznak, hanem kormányzati szinten is javaslatot tesz egy kabinetrendszer kialakítására (a közös döntéshozatal és felelősség érdekében, illetve mivel az adózást és az egyéb stratégiai kérdéseket nem lehet elszigetelten kezelni). Hangsúlyozza: a szerepek egyértelmü elhatárolása a civil és a katonai szférák között és azokon belül, valamint az együttmüködés kultúrájának kialakítása is fontos. (Thompson [1966] 70-71. o.) 
- A gerilla fázisban a kormányzatnak a bázisterületeket kell elöször biztositani - a felkelés előkészületi fázisában a fenyegetett területekre kell figyelni. Amennyiben a preventív lépések csődöt mondanak, az ország fontosabb, fejlettebb részeire kell koncentrálni. Ez jelentheti azt, hogy a kormány tudatosan elfogadja az ország egyes területeinek átmeneti feladását.

Az alapvető műveleti elvek a következők:

1. Megtisztitás (clearing): a felkelők kiszorítása adott területről. A megtisztításra kiválasztott területnek egy már megtisztított terület mellett kell feküdnie, és a területen még a művelet megkezdése előtt intenzív hírszerzési akciókat kell indítani. Az akció megindításakor el kell árasztani a területet rendőri és katonai erőkkel, ami a felkelőket menekülésre vagy háttérbe vonulásra ösztönzi. A biztonsági erőket úgy kell felállítani, hogy az ellenséges erők összevonása vagy a visszaszivárgás lehetetlen legyen. Megtartási terv és törekvés nélkül azonban mindez semmit sem ér.

2. Megtartás (holding): a módja attól függ, hogy már korábban is relatíve biztonságos terület volt, vagy újonnan megtisztított. A cél helyreállítani a kormányzat befolyását és megteremteni a közbiztonságot. Itt az intézkedések közé tartozhat stratégiai falvak kialakítása, falusi milíciák létrehozása, emberek és áruk mozgásának korlátozása a gerillák elszigetelésének és a szubverzív szervezet megsemmisítésének céljával. Alapos tervezést és módszeres végrehajtást igényel, és igazán sosincs vége; átfedésben van a győzni szakasszal.

3. Gyözni (winning): röviden a jó kormányzást jelenti. Sok apró tényező van, amit gyorsan és alacsony költséggel el lehet érni a mindennapokban (pl.: egészségügy, iskolák, javuló életszínvonal). Célszerü önmagukat állandósító vagy láncreakcióként müködő támogatási folyamatokat elindítani. A cél a lakossági érdekek biztosítása a stabilitásban azért, hogy segítse annak megszilárdulását. Amint a lakosság bizonyítja lojalitását a kormány felé, és a kormányerők már túlterjeszkedtek az adott területen (és ezzel a visszaszivárgás veszélye is elhárult), a területet biztonságosnak lehet nyilvánítani.

4. Gyözelem (won): a kormány a hosszú távú célokra koncentrálhat, vagyis egy gazdaságilag és politikailag stabil közösség kialakítására. A bevezetett korlátozásokat meg lehet szüntetni, lehet önsegítő programokat indítani és a demokratikus kezdeményezéseket erősíteni. Fontos, hogy sem a demokratikus 
elveket, sem a gazdasági fellendülést nem lehet bizonytalan környezetben eröltetni. (Thompson [1966] 111-114. o.)

Thompson a gerilla hadviselés jellemzőit és az ellene használható módszereket Gerilla hadviselés azonos közegbeli elmélet (Same-Element Theory of Guerilla Warfare) címen foglalta össze:

A gerilla erök sikerének két titka van: meg kell őrizniük a kezdeményezést (akkor és ott támadnak, ahol akarnak) és el kell kerülniük a fegyveres harcot a túlerővel szemben. Ha ezen elvek mentén képesek müködni, jó eséllyel a harci erejük és a moráljuk is jelentősen növekszik.

A felkelésellenes erők fő törekvése ennek megfelelően az, hogy védekezésre kényszerítsék őket. Ezt kis csoportokra bontással és a túlélésre koncentrálásra való késztetéssel lehet elérni, ami aláássa a gerillák harci erejét és morálját is. Módszere a saját közegükben való támadás, jelentős mủveleti tempóval. A három fontos közeg:

1. Lakott területek, beleértve a felkelők lakossági támogatását: megtisztítás és megtartás müveletek segítségével a lakosságot meg kell szabadítani a felkelők irányításától a szubverzív szervezet megsemmisítésével.

2. Lakatlan részek és háborús övezetek, amelyek menedéket nyújtanak a gerilláknak: itt a felkelésellenes eröknek a gerillákhoz hasonló környezetben kell müködniük. Megfelelő hírszerzési információk birtokában lehetőség nyílik arra, hogy a felkelők mozgásszabadságát nagymértékben korlátozzák. Azt azonban szem előtt kell tartani, hogy ezek a müveletek érintetlenül hagyják a felkelőinfrastruktúrát, így csupán másodlagosaknak tekinthetőek. A cél így az, hogy minél több katonai és félkatonai - az ellenséggel egy szinten harcolni képes erőt juttassanak be abba közegbe, ahol a felkelők vannak.

3. Az előbbihez hasonló, kisebb méretü müveletek alkalmasak az ellenséges kommunikációs vonalak zavarására a lakossági bázis és a gerillák között. (Thompson [1966] 115-119. o.)

A felkelésellenes küzdelemben kiemelten fontos a hírszerzés, ${ }^{52}$ a pszichológiai és információs müveletek szerepe, valamint a lakossági támogatás megszerzése.

\footnotetext{
52 Thompson a brit tradíciónak megfelelően egyszolgálatos modell létrehozását javasolta. Nagy-Britannia az ún. kooperáló hírszerzési modellt alkalmazza, ami azt jelenti, hogy a hírszerzés és elhárítás külön önálló szervezetek feladata, a koordinálási feladatokat pedig egy külön szervezet látja el. Az egyszolgálatos modell arra utal, hogy a hírszerző és elhárító szervezetek feladatai között elvben nem lehet semmilyen átfedés. Történelmileg ez a rendszer jelentős múltra tekint vissza, A szubverzió elleni fellépés kezdetben a londoni rendörség különleges ügyosztályának (Metropolitan Police Special Branch) a feladata volt, amit 1883-ban hoztak létre azzal a céllal, hogy az ír terrorista és
} 
A hírszerző szervezet fő célja a szubverzív szervezet és a gerillák közötti kapcsolatok megtalálása és a szubverzív szervezetbe való behatolás - ami egyúttal a gerillaszervezetbe történő behatolást is jelenti (Thompson [1966] 86. o.) -, ezáltal a fenyegetés teljes mértékben való megszüntetése saját területen. Ennek megfelelően arra kell törekednie, hogy minden felkelő személyazonosságáról a lehető legtöbbet tudja meg. (Thompson [1966] 84-85. o.) A cél az egyre pontosabb kép kialakítása az ellenségről, valamint a kisméretü katonai müveletekben a harcérintkezések számának növelése pontos információk alapján, lassan felmorzsolva a gerilla erőket. A katonai sikerek megerősítik a kormányzati sikerbe vetett hitet, és ideális esetben további információkat eredményeznek a lakosság soraiból. (Thompson [1966] 88-89. o.)

A felkelők ellen végzett pszichológiai műveletek és a lakosság irányába végzett információs műveletek fontosságát egyaránt hangsúlyozza. A lakosság felé és felkelők ellen irányuló információs műveleteket a hírszerzéssel szorosan együttműködve kell végezni. Az előbbinek az a célja, hogy növelje a lakosság kormány iránti bizalmát és lelkesedését, az utóbbié, hogy a serkentse megadást és csökkentse az ellenség morálját.

A felkelők ellen irányuló információs műveletetek középpontjába egy jól átgondolt amnesztiatervet kell állítani, mégpedig hármas céllal:

1. Bátorítson arra, hogy a felkelök adják meg magukat.

2. Szítson ellentéteket az alacsonyabb és a magas rangú felkelők között.

3. Olyan képet mutasson a kormányról, hogy az ,hatékony és határozott, de egyúttal igazságos és nagylelkü”. (Thompson [1966] 90. o.)

A lakossági támogatás megszerzése fontos része a felkelésellenes küzdelemnek. A felkelők aktív támogatóinak aránya általában a lakosság 1\%-át teszi ki. A kormányzat aktív támogatóinak aránya ideális esetben $10 \%$ körül van, de 20\%-nál sosem nagyobb. A lakosság fennmaradó része semleges. Ha a fennmaradó rész nyíltan nem is támogatná a kormányt, de hajlandóságot mutatna rá, akkor a szelektív terrorizmus és felkelés kudarcra lenne ítélve. (Thompson [1966] 63. o.) A legfontosabb propagandaelőny, amivel egy kormány rendelkezhet, az a lakosságnak a szavahihetőségébe vetett bizalma. Ezt csak úgy örizheti meg, ha szigorúan ragaszkodik a tényekhez. (Thompson [1966] 96. о.)

A modernizáció és a különböző társadalmi kezdeményezések, amelyek a lakosokat érdekeltté teszik a kormány hatalmon maradásában (mint például a 
társadalombiztosítás), fontos eszközök lehetnek a lakosság támogatásának biztosításában. (Thompson [1966] 66-67. o.)

\section{Frank Kitson: Alacsony intenzitású múveletek ${ }^{53}$}

Frank Kitson a brit hadsereg hivatásos tisztjeként számos felkelésellenes műveletben vett részt. Többek között Kenyában, Cipruson és Észak-Írországban szolgált, munkássága jelentős hatással volt a brit felkelésellenes megközelítés fejlődésére. Müve arra a feltevésre épül, hogy amennyiben sikerül megtalálni a felkelöket, jogilag megvan a lehetősége a megtámadásuknak (elfogásuknak és bíróság elé állításuknak, vagy rendkívüli törvények alapján történő letartóztatásuknak). (Kitson [1991] x-xi. o.) A fő törekvése annak vizsgálata, hogy a hadsereg miként járulhat hozzá a saját fellépésével és a polgári kormányzat szervezeteinek támogatásával a sikeres felkelésellenes müveletek végrehajtásához. (Kitson [1991] 6-7. o.) A mü akkor született, amikor az észak-írországi konfliktus intenzíven próbára tette a brit biztonsági erőket, ez azonban nem szerepel benne, de minden bizonnyal inspirálta a megírását. Alább a felkelésellenes küzdelemre vonatkozó részeit foglaljuk össze röviden.

\section{Szubverzió elleni fellépés}

A felkelők a szubverzív szervezetük segítségével igyekeznek kiterjeszteni az irányításukat egy adott területen élő lakosságra. A felkelésellenes erő célja az, hogy ezt a szervezetet megsemmisítse. A szubverzív szervezet elpusztításának fontos része a fegyveres csoportok felszámolása, ami előfeltétele a sikernek. (Kitson [1991] 49-50. o.) Hiba, ha a szubverzív szakaszban a kormány nem lép fel kellő szigorral a felkelésben résztvevők ellen, de demokratikus országban ez nehezen indokolható, és elveszhet miatta a lakosság egy része feletti irányítás. (Kitson [1991] 67. o.)

A békés eszközöket felhasználó szubverzív törekvések ellen a kormánynak több lehetősége is van a válaszadásra. Egyfelől alkalmazhat erőszakot a tüntetéshullámokkal szemben, de ez demokratikus környezetben politikailag vállalhatatlan. Másfelöl próbálkozhat a mozgalom vezetésének és tagságának megosztásával úgy, hogy ígéretet tesz korlátozott reformok végrehajtására. Ez esetben szükséges, hogy a kormány a beígért reformokat gyorsan megvalósítsa, és ezzel párhuzamosan a belbiztonsági

\footnotetext{
53 A mű 1971-es első kiadásának 1991-es utánnyomását tudtuk megszerezni, abból dolgoztunk.
} 
apparátusára támaszkodva felderítse és semlegesítse a szubverzív elemeket. Tovább erősítheti a kormányzati pozíciókat, ha a szubverzióval kapcsolatban nem álló, de a tüntetéseket támogató neves közéleti személyiségeket a maga oldalára állítja, illetve a tüntetésekkel nem szimpatizálók támogatását kommunikálja a lakosság felé. Az erőszakmentes szubverzív szervezetekkel szembeni erőszakos fellépés nem indokolt lévén ezek nyílt mozgalmak, amelyekbe egyszerü beszivárogni -, mivel az elpusztításuk terrorista vagy szabotázsakciókat válthat ki. (Kitson [1991] 87-88. o.)

Problémás, ha a politikai vezetés a feltünő fegyveres csoportokban egyszerü banditákat lát, és nem hajlandó keményen fellépni ellenük. Előfordul, hogy a kormány azért nem fordul feléjük kellö figyelemmel, mert nem akar pánikot kelteni. Az ilyen hozzáállás következménye, hogy a kormányzat nem fordít kellő forrásokat megelőző jelleggel a fenyegetés elhárítására. Nehézséget jelent, ha a korai szakaszban a látszat fenntartása érdekében a kormány nem hajlandó nemzeti szintü koordinációs testületet létrehozni a felkelés elleni fellépésre, mert így a civil-katonai koordináció megnehezül.

A törvényességre lehet úgy tekinteni, mint fegyverre az arzenálban, de úgy csak lepel lesz a törvénytelenségekre, és ez aláássa a kormányzat legitimitását. A törvénynek semlegesnek kell maradnia, de a törvényhozás fontos személyeit diszkréten be kell kapcsolni a koordináló bizottság munkájába. Idővel a kormányzat törvényeket kezdeményez a szubverzió és a felkelés kezelésére. Okozhat nehézségeket, ha a törvényhozás nem képes ezeket kellő időben, minőségben és mennyiségben elfogadni, mert akkor a konfliktus kimenetele szempontjából fontos politikai kérdések körül növekedni fognak a problémák.

Az erő alkalmazása körüli problémák a kezdeti szakaszban többfélék is lehetnek. Előfordulhat, hogy a politikai elit el akarja kerülni az erő nagyarányú alkalmazását, mert attól tart, hogy rossz hatása lesz a közvéleményre. Másfelől viszont a túl kis erő alkalmazásának katonai problémái vannak. (Kitson [1991] 68-70. o.)

A szubverzió elleni fellépésnek három szintje és célcsoportja van:

1. a párt- vagy frontszervezet és annak sejthálózata

2. a szervezet fegyveres csoportjai

3. a lakosság

A hatékony szubverzió elleni fellépés egy terv kidolgozását teszi szükségessé, melynek tartalmaznia kell olyan lépéseket, amelyek az életszínvonal fenntartására (amennyiben lehetséges, növelésére) törekednek, de egyúttal figyelmet kell fordítania a szubverzív szervezet elpusztítására. Ezt előrelátó módon kell végrehajtani, mert annak 
nincs értelme, hogy egy anyagilag csődbe ment közösség maradjon a szubverzív szervezet megsemmisítése után.

Fontos szempont a felkelők által okként használt sérelmek lehetőségek szerinti orvoslása. Abból érdemes kiindulni, hogy a lakosság inkább a kormányzat által kezdeményezett, kevésbé mélyreható reformokat fogja támogatni, mint a szubverzív szervezet irányából érkező radikális javaslatokat (minden egyéb feltétel egyezése mellett). Ennek az az oka, hogy a kormányzat sikerébe vetett hit a lakosság részéről valószínúleg nagyobb, ezért érdemes a reformokat összekötni a felkelésellenes tevékenységgel. (Kitson [1991] 50-51. o.)

A hadsereg feladata a felkelésellenes müveletekben

A hadsereg két alapfeladata:

1. Megfelelően kiképzett, felszerelt és felkészített egységek biztosítása.

2. Megfelelö felkészítésü vezetőket és törzstiszteket kell produkálnia, akik megfelelő tanácsokkal tudják ellátni a kormányzatot minden szinten a hadjárat sikeres lefolytatásához.

A hadsereg állományára más fontos feladatok is várnak:

1. Tisztek küldése olyan szervezetekhez, amelyek nagyarányú bővülés előtt állnak.

2. Ki kell építeni a hírszerzést, figyelmet kell fordítani az ellenséges lakosságszabályozási kísérletekre és a propagandára.

3. Terjeszteni kell a saját álláspontot.

4. Néhány esetben segíteni kell a kormányt a lakosság feletti irányítás megszervezésében, amire a felkelök is törekednek. (Kitson [1991] 71. o.)

Kitson a felkelésellenes mủveleteket a brit hagyományoknak megfelelően komplex, katonai-politikai-gazdasági lépéseket igénylő konfliktusoknak tekintette, amelyekben a katonai fellépés alá van rendelve a polgári hatóságoknak. A hadsereg csak a legalacsonyabb szinten müködhet önállóan, és akkor is civil szervezetekkel együttmüködésben. Kiemelte, hogy civil részröl elvárják a katonáktól, hogy igazodjanak a konfliktus szükségleteihez, de várható, hogy a konfliktus elején a felek közötti munkamegosztásban (ha nincs megfelelően felkészítve a feladatára a katona) ellentétek fognak kialakulni. Mivel a katonák a helyi viszonyokat sokkal jobban ismerő köztisztviselői gárda mellé kerülnek, hátrányból indulnak a konfliktus megértését illetően. (Kitson [1991] 7. o.)

Bevetési lehetőségeik: 
- Információszerzés (megfigyelés, foglyok ejtése, iratok zsákmányolása stb.).

- Ellenséges erők által használt útvonalak megfigyelés vagy ellenőrzés alá vonása, azok jelenléttel való kiszorítása adott, addig biztonságosnak vélt területekről. (Kitson [1991] 97-98. o.)

Túl sok katona bevetése hátrányos lehet, mivel sok célpontot ad az ellenségnek, az irányítás megnehezedik, és a kialakuló összecsapások miatt elkerülhetetlen, hogy a civil áldozatok száma is növekedjen. Ezért Kitson az erők gazdaságos bevetését és helyben létrehozott kisegítő erők alkalmazását javasolta.

Taktikai szinten a francia quadrillage-t és a brit keret müveleti rendszert tekintette alkalmazható modellnek. Ezek lényege, hogy minimális erő alkalmazásával állandó jelenlétet biztosítanak a lakosság körében. Az offenzív müveletek előtt ezt az erőt megerősítve kell megindítani. Ezen a ponton probléma szokott lenni, hogy a támadásra kivezényelt egység parancsnoka magasabb rangban van, így nem a helyi viszonyokat ismerő parancsnok útmutatása szerint akar fellépni. Kitson áthidaló javaslata, hogy olyan erőket kell létrehozni, melyek egymagukban is képesek keretmüveletek és offenzív müveletek végrehajtására. (Kitson [1991] 132-135. o.)

\section{Hírszerzés}

A kezdeti szakaszban a szubverzióval szembeni fellépéshez hatékony belbiztonsági szervezetre van szükség. Demokratikus országokban az ilyen tevékenységet sokan nem tartják összeférhetőnek a szabadság eszméjével, de ez szükséges a sikerhez. (Kitson [1991] 71. o.)

Igények a belbiztonsági szervezettel szemben: nagy létszámnövekedésre van szükség. A kezdeti időszakban a kevés, de jó minőségü források létrehozása a lényeg, el kell mozdulni a politikai információk felől a műveleti információk irányába, amire egészen a konfliktus végéig szükség lesz.

Az ellenség jellegéből fakadó problémák: a cél kezdetben egy kicsi, politikailag elkötelezett és biztonságra ügyelő szervezet, amely jelentős növekedésen megy keresztül. A későbbiekben ennek megfelelően megnő a célpontok száma. A fegyveres csoportok számának növekedése megnehezítheti a hírszerzési munkát.

A hadsereg a hírszerzés kérdéskörébe két módon kapcsolódik közvetlenül. Egyfelől érdekelt a fejlődésében, mivel a fegyveres harc szakaszában ennek a szervezetnek az információira kell majd támaszkodnia müveleteinek tervezésekor és 
végrehajtásakor. A hadsereg igényei a műveleti szükségletek miatt eltérőek, sok alacsony szintű hírforrást igényelnek, így a hadsereg érdekelt abban, hogy a belbiztonsági szervezet a tevékenysége során a katonai szempontok érvényesülésére hangsúlyt helyezzen. Ezt azzal valósíthatja meg, hogy személyi állományt irányít át a hírszerző szervezet létszámának növelésére, de arra is kényszerülhet, hogy olyan területeken, amelyek nincsenek a belbiztonsági szervezet által lefedve, saját maga hozzon létre hírszerző hálózatokat. (Kitson [1991] 73-74. o.) Vagyis röviden: a hadsereg feladata segíteni a hírszerző szervezet munkáját, nem elég egyszerűen összekötő tiszteket kiküldeni. (Kitson [1991] 77. o.)

\section{Információs müveletek}

A feladat lényege, hogy akadályozni kell az ellenség ilyen jellegü müveleteit és közben érvényesíteni a saját üzenetet. Ennek előfeltétele, hogy szakembereknek felmérést és értékelést kell végezni a megfelelő politika meghatározására, majd ennek megfelelő propagandaanyagokat kell készíteni és hatékonyan terjeszteni. Arra is felhívja a figyelmet, hogy a defenzív intézkedéseket sem szabad figyelmen kívül hagyni, és ehhez szükség van az ellenséges propaganda felderítésére alkalmas technológia alkalmazására (pl.: bemérés, zavarás stb.).

Kitson is önálló szervezet létrehozását javasolja erre a célra, amely szorosan együttmüködik a hírszerző szervezettel. A szervezet legalacsonyabb taktikai szintig való kiterjesztését javasolja úgy, hogy az adott szinten lévő tanácsban ennek a szervezetnek a képviselője feleljen a pszichológiai hadviselésért. Fő feladata, hogy a felkelésellenes erő sikereinek hírét eljuttassa a lakossághoz, illetve elhárítsa az ellenséges propagandát. (Kitson [1991] 77-78. o.)

\section{Neoklasszikus szakasz (1982 után)}

\section{1. doktrínák}

1995-ben adták ki a Felkelésellenes müveletek (Counter Insurgency Operations) címü doktrínát, amelynek szövege nem hozzáférhető a nyilvánosság számára. 


\section{Irak (2003-2007)}

A vázolt hosszú fejlödési folyamat ellenére a brit erők Irakban nem tudtak megfelelni az elvárásoknak. A szárazföldi hadmüveletek lezárulta után megszállási feladatokat láttak el Irak déli részén, a Dél-keleti Többnemzeti Hadosztály (MultiNational Division (South-East), MND(SE)) keretében. Ahogyan az elnevezés is mutatja, nem pusztán brit erők vettek részt a megszállási feladatok ellátásban, de az erők java brit volt. A brit szektor a többségében síiták lakta területek jelentős részére terjedt ki, beleértve Irak második legnagyobb városát, Bászrát.

A megszállási feladatok megkezdése után nem sokkal problémák jelentkeztek a brit szektorban. A déli területek szerepe a kialakuló felekezetek közötti konfliktusban nem volt elhanyagolható: a síita fegyveres csoportok itt szerezték meg azokat az összegeket, amelyekből a tevékenységüket finanszírozták. Ebbe más illegális tevékenységek mellett beletartozott az olaj- és árucsempészet és a teherforgalom utáni vámszedés. (Ledwidge [2012] 51-52. o.)

A britek több olyan hibát is elkövettek, amelyek a nem megfelelő felkészülés és vezetés számlájára írhatóak. Ezek közül talán a legsúlyosabb, hogy a Királynő Lancashire Ezredének (Queen's Lancashire Regiment) kötelékébe tartozó katonák kínzási ügybe keveredtek, ahol halálos áldozat is volt. ${ }^{54} \mathrm{~A}$ brit erők nem voltak képesek a kialakuló felekezetek közötti és felekezeteken belüli erőszak megfékezésére sem.

A biztonsági erők felépítésének kérdése náluk is fontos szerepet játszott. Elhibázott lépésnek bizonyult, hogy a különböző helyi milíciákat beolvasztották a rendörségbe. A cél hivatalosan az volt, hogy az irakiakat minél előbb felkészítsék a biztonsági feladatok átvállalására, a gyakorlatban azonban a rendőrség a bizonytalanság forrása lett. A britek nem hoztak létre ellenőrző rendszert a rendőrség felkészültségének ellenőrzésére, és nem próbálták meg megtörni a rendőri erőben a milíciák befolyását. (Ledwidge [2012] 32-33. o.) Az elhibázott rendőrségi politikára jó példa a bászrai rendörség Súlyos Bünügyek Osztályán történt eset. Itt a britek megfigyelés alá helyezték az osztály egyik tisztjét, (Urban [2011] 95-96. o.) a müvelet során azonban iraki rendőrök elfogták a brit különleges erők két katonáját. Ezután a britek kénytelenek voltak erőszakkal beavatkozni és kiszabadítani a katonáikat, mivel azt feltételezték, hogy a rendőrök át fogják játszani őket a Mahdi Hadserege (JAM) milíciának. (Ledwidge [2012] 32-34. o.)

\footnotetext{
${ }^{54}$ A kérdéssel kapcsolatban bővebben ld. a Baha Mousa nyilvános vizsgálóbizottság jelentését. http://www.bahamousainquiry.org/report/index.htm
} 
2007 decemberére a brit felügyelet alatt álló területek visszakerültek iraki kézre. A britek a minél fájdalommentesebb kivonulásra törekedtek, és ennek érdekében a síita milíciákkal is hajlandóak voltak kompromisszumot kötni, amit utólag egyfajta meg nem támadási paktumnak lehet értelmezni. A megállapodás szerint a briteknek egyeztetniük kellett a JAM-mel, hogy mikor akarnak belépni a területükre, cserébe a JAM vállalta, hogy nem támadja a brit erőket provokáció nélkül. A hivatalos magyarázat erre az volt, hogy a fokozatos kivonulással az iraki helyi szerveket akarták arra kényszeríteni, hogy saját erőből birkózzanak meg a kialakult helyzettel. (Ledwidge [2012] 47-48. o.) Paradox módon erre a brit kivonulás után sor is került: az iraki kormány 2008 elején megindította a Lovagroham hadmüveletet, melynek célja a JAM elleni fellépés volt. A britek az amerikaiakkal együtt segítséget nyújtottak ehhez, de ettől függetlenül a brit megszállás rossz emléket hagyott Irakban. (Ledwidge [2012] 53-55. o.)

Összességében a brit jelenlétet úgy lehetett jellemezni, hogy ők voltak a legnagyobb és legerősebb milícia Bászrában, de a felkelésellenes szerepkör hatékony ellátásához sem létszámuk nem volt, sem igazi politikai akarat. Emellett az is megállapítható, hogy annak ellenére, hogy a britek jelentős múlttal és egy jól megírt felkelésellenes doktrínával rendelkeztek, képtelenek voltak mind a múltbeli tapasztalatok, mind pedig az aktuális elmélet megfelelő alkalmazására. 


\section{FEJEZET \\ A FRANCIA FELKELÉSELLENES ELMÉLET FEJLŐDÉSE}

A felkelésellenes hagyományok terén Franciaországnak gazdag múltja van, de nem lehet egységes iskoláról beszélni, mivel a hadsereg mint intézmény sosem állt mögé teljesen. Ezzel együtt jelentős szerzők fontos műveinek volt a tárgya, és a francia hadsereg egyes egységeinek kultúrájában a mai napig fontos szerepet játszik. (Durand [2010] 11. o.)

Fontos kiemelni, hogy a francia terminológia eltér az angolszásztól. Amit az angolszász terminológia felkelésnek nevez, arra a francia a lázadás, a szubverzív hadviselés és a forradalmi hadviselés kifejezéseket használja. A felkelés szó a francia terminológiában spontán eseménysort jelent. (Durand [2010] 16. o.) A forradalmi hadviselés kifejezés a konfliktusok jeles kutatója, Bernard Fall szerint az indokínai háború alatt fogságba esett francia tisztek nyelvhasználatára vezethető vissza, akik a fogva tartóiktól vették át. (Fall [2005] 370. o.) Fall az elmélet lényegét egy egyenletben így foglalta össze: $\mathrm{RW}=\mathrm{G}+\mathrm{P}$, vagyis a forradalmi háború annyi, mint gerilla harcmodor plusz politikai akciók. (Fall [1998])

\section{Preklasszikus szakasz. A 19. század közepétől a második világháborúig}

A francia felkelésellenes műveletek Algériában kezdődtek az 1830-as években, és ott is fejeződtek be az algériai függetlenségi háború győzelmével, 1962-ben. (Durand [2010] 11. o.) 1830-ban X. Károly indított háborút Algéria megszerzéséért, ami igen hosszan elhúzódott. A területet 1848-ban nyilvánították Franciaország részévé, de 1870ig még katonai igazgatás alatt állt, a hadügyminisztérium alá tartozott. Témánkat tekintve három jelentős személyiség emelhető ki ebből az időszakból: Thomas-Robert Bugeaud, Joseph-Simon Galliéni és Hubert Lyautey. (Rid [2009] 620. o.)

Thomas-Robert Bugeaud (1784-1849) a jénai csata és a félszigetháború veteránja, a francia parlament tagja, jeles agrárszakember, 1840-1847 között algériai 
fökormányzó. ${ }^{55} \mathrm{Az}$ algériai szerepvállalása idején a félszigetháborúban szerzett tapasztalatait használta fel elsősorban, spanyol és francia oldalról egyaránt. A kontinentális háborús tanokat nem tartotta alkalmazhatóknak a gyarmatokon.

Elődei három nagy problémával szembesültek Algériában:

- A megerösített pontok védelme leköti az állomány jelentős részét.

- A logisztikai igények túlzottan lelassítják a nagy egységeket.

- Egészségügyi problémákat okoz az Algériában folyó harc. (Rid [2009] 624. o.)

Bugeaud a nagy kötelékek helyett kisebb egységeket vetett be, és a tüzerőtől való függőséget károsnak ítélte. Zászlóalj szintü mobil egységeket szervezett (colonnes mobiles), amelyek a felkelök mobilitását másolták, és az ellenséges vonalak mögötti tartós müködésre voltak kitalálva. (Durand [2010] 12-13. o.)

Egyik legfontosabb újítása az Arab Iroda (Bureaux arabes) újbóli megszervezése volt 1841-ben. Ezt eredetileg Avizard tábornok hozta létre, feladata a helyi ügyekkel való foglalkozás volt, de 1834-ben sikeres volta ellenére feloszlatták. Bugeaud alatt a szervezet feladata a törzsek - úgy a francia uralom alatt lévők, mint a függetlenek politikai helyzetének feltérképezése volt. Az Iroda minden helyi hatóság felett állt, és a francia politika kommunikálása mellett a francia hírszerzés segítése is a feladatai közé tartozott. 1848 után a katonai igazgatás alatt álló területeken müködött, állományát a francia hadsereg (azon belül a gyalogság) és a helyiekböl toborzott katonák alkották, akik ideiglenesen lettek az egységeiktől átcsoportosítva erre a feladatra. (Rid [2010] 736-737. о.)

Bugeaud nevéhez füződik a razziának mint katonai eljárásnak a bevezetése. A kifejezés az arab nyelvből származik, a franciák a beduin törzsektől vették át. Ott olyan rajtaütést jelentett, amelyben rivális törzsek egymás értékeit igyekeztek megszerezni, általában vérengzés nélkül. Az első jelentős razziára francia részről 1846-ban került sor, célja egy törzsi lázongás leverése volt, és egyáltalán nem volt vértelen. Bugeaud gyakorlatilag doktrína szintre emelte a razziát (Rid [2010] 731-733. o.), amellyel nemcsak félelmet akartak kelteni, hanem anyagi és emberveszteséget igyekeztek okozni az ellenszegülőknek és elrettenteni az ellenszegülni készülőket. (Rid [2010] 735. o.)

A razzia a francia gyarmatosítás velejárója volt, ahogyan az erőszak jelentős mértékű alkalmazása is, azonban politikailag veszélyesnek bizonyult. A hadseregük brutalitásáról Franciaországba eljutó hírek erős ellenérzést és politikai támadásokat ${ }^{55}$ Gooch, Brison D.: Bugeaud, Thomas-Robert, Marshal, Duc D'Isly 1784-1849, Encyclopedia of
Revolutions of 1848, Ohio University 1997, http://www.ohio.edu/chastain/ac/bugeaud.htm 
váltottak ki. Az algériai fellépés egész Európában rossz hírét keltette a francia hadseregnek, a katonai vezetés magyarázkodásra kényszerült miatta. Emellett a túlzott erőszak cselekvésre késztette a helyieket is, akik a mészárlások hatására kovácsolódtak össze és kezdtek erőszakos megmozdulásokba. (Rid [2009] 629-631. o.)

Bugeaud tudta, hogy az erőszak önmagában nem elég a helyiek irányítására, és felismerte, hogy egy új rendszert nem lehet rájuk eröltetni. Ezért a helyi vezetőket kooptálta: az Arab Irodák munkatársaira várt a feladat, hogy felügyeljék, illetve felkészítsék öket a feladatra. Mindezt csekély katonai támogatás mellett kellett végrehajtani. Az Arab Irodák a katonai parancsnoki lánc részei maradtak, általában hadosztálynak voltak alárendelve, irányításukat a Politikai Iroda (bureaux politique) látta el. Amit ma kulturális hírszerzésnek neveznénk, az Arab Irodák fontos feladata volt, de a törzsekkel való kapcsolattartás mellett az igazságszolgáltatásban, a vallási ügyekben és az adószedésben is fontos szerepet játszottak, így a saját régiójukban elsőrendü információik voltak a mindenkori törzsi politikai helyzetről. Emellett semlegesnek kellett lenniük, és távol kellett maradniuk az erőszakos cselekedetektől. Az 1870-es évekre az irodák száma lecsökkent a kontinentális ügyek, illetve a szervezetet ért kritikák miatt (egy részük szerint nem voltak elég hatékonyak, más részük szerint túlzottan azok voltak, és a hadseregnek egyébként is csak hagyományos feladatokat kellene végezni). (Rid [2010] 739-741. o.) Bugeaud a gazdasági kapcsolatok kialakítását és elmélyítését is fontosnak tartotta az irányítása alá került területeken. (Rid [2009] 625. o.)

Joseph-Simon Galliéni (1849-1916) hivatásos tengerészgyalogsági tiszt volt, a mai Mali területén és a tonkini térség pacifikálásában tett szert jelentős tapasztalatokra.

A nevéhez füződő legjelentősebb siker a madagaszkári felkelés leverése volt. A konfliktus igen bonyolult belső ellentéteken alapult, amit az ott állomásozó francia erők kezdetben nem kezeltek megfelelően. Madagaszkárra érkezése utáni első intézkedése az volt, hogy koncentrálta az igazgatási funkciókat és létrehozta a territoire militaire-t, amely a katonai és a politikai tevékenységért volt felelős. A szervezetet igyekezett decentralizálni annak érdekében, hogy a helyi problémákra helyi válaszokat tudjanak adni.

Következő intézkedése a felkelők és a helyi elit, illetve lakosság között kialakult kapcsolat megbontására irányult. Elrendelte, hogy a francia erők erődemonstrációkat végezzenek jól látható módon, hogy a lakosság biztonságban érezhesse magát a védelmük alatt, majd a helyi elitet eltávolította a hatalomból. Alacsonyabb szinteken a 
katonák a helyi vezetés ellenőrzését végezték, amivel elérték, hogy a fegyveres lázadók visszaszorultak a sürübben lakott települések közeléből a nehezebben megközelíthető helyekre. Galliéni a ma olajfolt stratégiaként (tache d'huile) ismert eljárást követte: a lakott területek biztosítása után a ritkán lakott területek visszaszerzésére koncentrált. A siker kulcsa a politikai és a katonai fellépés megfelelő kombinálása volt. A katonai igazgatási rendszer a jellegéből adódóan azonban csak átmeneti lehetett. (Rid [2010] 748-750. о.)

Hubert Lyautey (1854-1925) Galliéni közeli beosztottja volt a tonkini térségben és Madagaszkáron is, és fontos szerepet játszott Marokkó gyarmatosításában. Galliéni módszereit fejlesztette tovább, könyvet írt Lettres du Tonkin et de Madagascar ${ }^{56}$ címmel, amelyben részletezte az olajfolt eljárás hátterét. A gyarmatosítás katonai részét pacifikálásnak nevezte, és alapvetően eltérőnek tartotta a hagyományos katonai feladatoktól. Mint írta: „helyi szinten a politikai támogatás szociális és igazgatási munka segítségével lehetővé teszi tartós siker elérését katonai taktikai szinten.” (Durand [2010] 13. o.)

Lyautey szerint a pacifikáció sikerét a kényszer és az egyetértés keveréke adja. Előbbit az erő alkalmazásával (pl.: lakosság irányítása), utóbbit a helyi elitekkel való együttmüködés révén lehet elérni. A lakossággal finoman kell bánni, mindenkor a politikai megközelítés az elsődleges, a pusztítás a legutolsó lehetőség. Szerinte a legjobb tiszteket kell kiválogatni az ilyen feladatra, és ki kell őket vonni a rotáció alól. (Durand [2010] 14. o.) Azt javasolta a ma is problémát jelentő rotáció egyik káros hatásának a kiküszöbölésére, hogy a gyarmati ügyekkel foglalkozó tiszteket küldjék adminisztratív szabadságra - ami kialakítaná bennük az ún. „fordított honvágyat” -, ahelyett, hogy véletlenszerüen új állomáshelyre küldjék őket és veszni hagyják az értékes kapcsolataikat és tapasztalataikat. (Rid [2010] 753. o.)

Galliéni és Lyautey egyaránt a parancsnoki lánc egységét hangsúlyozták, egyesítve a katonai és politikai feladatokat, és kizártnak tartották a gyarmati és a konvencionális erők cseréjét. A 19. hadtest (Armée d'Afrique) létrejöttével kialakult a gyarmati erők magja. Az idegenlégió és a francia tengerészgyalogság egységei alkották ezt az erőt. A gyarmati ezredek általában teljesen elkülönülö identitást alakítottak ki a hadseregen belül - ma régiment d'infanterie de marine, RIMA néven ismertek -,

\footnotetext{
${ }^{56}$ A mủ olvasható az alábbi linken:

http://ia600204.us.archive.org/9/items/lettresdutonkine00lyau/lettresdutonkine00lyau.pdf
} 
olyannyira, hogy a hagyományos (metro) és a gyarmati (coloniaux) egységek érdekcsoportjai között összeütközések is voltak. (Durand [2010] 14. o.)

A fentiek alapján elmondhatjuk, hogy a francia gyarmatosítás nem volt sikertörténet, de olyan tapasztalatokat hozott, amelyeket később hatékonyan alkalmaztak. A brit modellel ellentétben itt a hadseregé volt a föszerep a közigazgatás terén is, ami egyfajta alternatív megközelítés a brithez képest. Fontos eleme, hogy a vezetők sok időt töltöttek a müveleti területen, beszélték a helyi nyelveket és jól ismerték a helyi viszonyokat, és mindezeket a maguk javára tudták fordítani, ha a szükség úgy hozta. Bugeaud, Galliéni, Lyautey és mások gyarmati tapasztalatai jelentős hatással voltak a későbbi generációkra. A hadseregben különösen Bugeaud és Lyautey rendelkezett jelentős követői táborral.

\section{Klasszikus szakasz. A második világháború és utóélete}

A második világháborúban a kontinensen elszenvedett vereség jelentős megrázkódtatást okozott a francia katonai elitben. Bár a háború előtt a francia hadsereget ütőképesnek ítélték a kortársak, a gyakorlatban nem volt képes alkalmazkodni a kihívásokhoz. Emiatt az ország részben megszállás alá került, az amerikai partraszállás után pedig tényleges hadszíntérré változott. Mindez jelentős megosztottságot okozott az országon belül.

Franciaország két módon vett részt a háborúban: ${ }^{57}$ konvencionálisan a gyarmatokon $^{58}$, majd a partraszállás után otthon, illetve a partraszállásig irregulárisan otthon. Ennek megfelelően az irreguláris fellépés francia részről nem választás volt, hanem kényszer, és a háború alatt, illetve után a francia ellenállás tagjai nagy számban csatlakoztak a hadsereghez. A második világháború az angolszász hatáson és a harci cselekményeken keresztül alapvető hatást gyakorolt a kontinentális hadsereg harcmodorára. (Hood [2010] 247-248. o.)

A háború végén, a negyedik köztársaság létrejöttével, egy instabil politikai rendszer jött létre Franciaországban. A nemzeti büszkeség helyreállításának igénye

${ }^{57}$ A Vichy Franciaország szerepét ezen a ponton nem kívánjuk tárgyalni.

${ }^{58}$ De Gaulle az idegenlégió néhány egységét, gyarmati csapatokat, több ezer tengerészt és a gyarmatokon lévő légierő egy részét tudta kezdetben mozgósítani a céljaira; ezt az erőt a háború alatt kb. 70000 katonára és civilre sikerült bővíteni, logisztikában és pénzügyi kérdésekben azonban a szövetségesektől függött. A kialakult helyzetben azonban ezek az erők szinte mindig más nemzet parancsnoksága alatt harcoltak. Hood, Ronald Chalmers III.: Bitter Victory: French Military Effectivenes During the Second World War, in: Millett, Allan R. és Murray, Williamson: Military Effectivenes: Volume 3 The Second World War, Cambridge University Press, 2010. 223-224. o. 
komoly problémát jelentett a gyakori kormányváltások miatt, és megnehezítette a tevékenységet a gyarmatokon. ${ }^{59}$ Nem szabad megfeledkezni arról, hogy Franciaország nemcsak a németektől szenvedett vereséget, hanem a japánoktól is a Távol-Keleten, és a drága győzelem után nagy igény volt a korábbi tekintély visszaállítására. Ez az igény szülte az első olyan háborút a második világháború után, amely a felkelésellenes megközelítés újraértékelését hozta magával.

\section{Indokína (1946-1954)}

A francia kormány vissza kívánta szerezni az indokínai gyarmatát, ami a mai Vietnam, Laosz és Kambodzsa területét jelentette. A második világháború után ehhez még nem voltak meg az eszközei, így a britek és kínai nacionalista erők szállták meg a területet. A Vieth Minh a japánok elleni harcban - szövetséges támogatással - ütőképes szervezetet hozott létre. A harcok lezárulásával a terület függetlenségét kívánta elérni, és ezt formálisan deklarálta is. (Fall [2005] 27. o.)

A francia erők 1946-ban tértek vissza Indokínába. A terület státusának megváltozása politikailag nem volt elfogadható a számukra, így a katonai összeütközés elkerülhetetlen volt. A francia erők azonban komoly politikai és gazdasági korlátokba ütköztek, erőforrásaik a konfliktus előrehaladásával egyre csökkentek, így az Egyesült Államok növekvő támogatására volt szükségük a háború folytatásához.

Francia részről a konfliktus első részében (1946-1949) a konvencionális összecsapás lehetőségét keresték a Vieth Minh erőkkel. (Fall [2005] 27-28. o.) Az 1949es év fordulatot hozott a konfliktusban: a kínai kommunista gyözelemmel a Vieth Minh erők szert tettek egy velük határos aktív támogatóra. Támogatásával a Vieth Minh koncentrált támadásokat indított a határon létrehozott francia erődítmények ellen a zavartalan kínai kapcsolatért, és 1950 folyamán ezt el is érte. (Fall [2005] 32-33. o.) A koreai tủzszünet megkötése után a támogatás még növekedett, és 1953-ra hét gyalogos és egy tüzérségi hadosztály állt a Vieth Minh rendelkezésére. (Fall [2002] ix. o.) Korszerü légvédelmi tüzérséget, tüzérségi eszközöket, gyalogsági fegyvereket és nagy mennyiségü lőszert kaptak Kínától, továbbá modern szállító eszközöket, köztük szovjet gyártmányú teherautókat. (Fall [2005] 94. o.)

\footnotetext{
${ }^{59}$ Dien Bien Phu elestekor Jospeh Laniel kormánya megbukott; Laniel a negyedik köztársaság huszadik miniszterelnöke volt. Horne, Alistair (2006): A Savage War of Peace: Algeria 1954-1962, New York Review of Books, 68. o.
} 
A franciák 1950-től sorozatos kudarcokat voltak kénytelenek elszenvedni ÉszakVietnamban. 1951-ben a Vieth Minh döntő offenzívára szánta el magát, ami kudarccal végződött. (Fall [2005] 36-41. o.) Ezután a franciák próbálkoztak a Vieth Minh erők döntő csatára kényszerítésével, aminek egyik eredménye volt a Hoa-Binh körül kialakult csata. A franciák az ejtőernyős egységeiket mélyen az ellenséges területre bedobva próbáltak győzni, a Vieth Minh pedig fel akarta őrölni a francia erőket. A franciák végül légi úton kivonták az eröiket. (Fall [2005] 47-60. o.)

Az ezt követő időszakban a konvencionális Vieth Minh erők sikerrel szereztek területeket a franciáktól, bár jelentős veszteségek árán. A francia hadvezetés ezután is konvencionális választ igyekezett találni a problémára, kevés figyelmet fordítva a Vieth Minh irreguláris módszereire. A franciák végül Hoa-Binh mintájára Dien Bien Phu-nál próbáltak döntő csapást mérni a Vieth Minh erőkre, de pontosan az ellenkezője történt annak, amit a francia vezetés tervezett. A francia erők megsemmisülésével és fogságba esésével a politikai támogatás végleg elfogyott az indokínai kaland mögül a negyedik köztársaságban, annak ellenére, hogy katonailag a franciák távol álltak a teljes verségtől. A franciák tárgyalásba kezdtek, és a genfi konferencia végeredményeként feladták a területet.

A konfliktusnak két jelentős hatása volt: 1/ Megalapozta a francia hadsereg tisztikarában annak az elszánt rétegnek a kialakulását, amely nem akarta tovább türni a területvesztést, és a francia gyarmatbirodalom megtartását tartotta legfőbb feladatának. 2/ A tisztikarban sokakat a hadviselésről kialakított alapvető nézeteik felülvizsgálására késztetett. Ennek eredményeként készek voltak akár a Vieth Minh által alkalmazott taktikák átvételére. A konfliktus ugyanakkor jelentős kísérleti terepet nyújtott a franciáknak a saját nem konvencionális képességeik tesztelésére, amelyeket később elsősorban Algériában - a felkelésellenes fellépés részeivé tettek.

Az egyik ilyen „kísérlet” volt a G.C.M.A. (Groupements de Commandos Mixtes Aéroportés, Vegyes Ejtőernyős Kommandó Csoportok) létrehozása 1951-ben. Ezek jelentős önállósággal bíró, az ellenséges vonalak mögött müködő különleges egységek voltak, amelyek a Vieth Minh politikájával nyíltan szembeszállni kívánó helyi csoportok megszervezésére specializálódtak. A csoportok feladata az volt, hogy mélyen az ellenséges vonalak mögött tartós akciókat hajtsanak végre. Vagyis a G.C.M.A. egy francia vezetésű gerilla erő volt, amelynek hírszerzési szerepe sem elhanyagolható. 1953-ban megváltoztatták a nevét G.M.I.-re (Groupement Mixte d'Intervention, Vegyes Beavatkozó Csoportok), de ez a lényegen nem sokat változtatott. Érdekesség, hogy a 
G.C.M.A. vezetője Roger Trinquier volt, akinek a Modern hadviselés című munkája a felkelésellenes irodalom klasszikusai közé tartozik, máig tartó hatással. Az egység kötelékében 1954-re, a konfliktus végére, mintegy 15 ezer fő szolgált. Az utánpótlást repülőgépekkel oldották meg, ami a növekvő létszám miatt nem kis terhet rótt a légierőre. (Fall [2005] 268-270. o.) Bár a hírszerzési hatékonysága felől megoszlottak a vélemények, kétségtelen, hogy jelentős számú ellenséges erőt kötött le, és a lehetőségeihez képest segítette a francia stratégiai és müveleti célokat.

\section{Algériai függetlenségi háború (1954-1962)}

Algéria helyzete abból a szempontból eltért Indokínától, hogy hivatalosan Franciaország részét képezte, és jelentős számú telepes (pied noir) élt a területén. (Horne [2006] 51-54. o.)

A nehezen kivívott függetlenséghez hosszú és véres út vezetett, amelynek legjellemzőbb formája a felkelés, amely korlátozott külföldi - marokkói és tunéziai támogatással rendelkezett. (Horne [2006] 264-265. o.) Kezdettől jelen volt benne a francia civilekkel szembeni brutalitás, de minőségi fordulatot a Philippeville-i mészárlás hozott. Az erőszak a telepeseket is erőszakos fellépésre késztette, amit a francia erők sokszor nem tudtak vagy nem akartak kordában tartani. (Horne [2006] 118-122. o.)

A felkelés elszántan igyekezett aláásni a francia hatóságokba vetett hitet, és hatékonyan gyilkolta a hatóságokkal együttműködő helyieket. A módszerek változatosak voltak és az elrettentést szolgálták. Gyakoriak voltak a halált okozó kínzások, csonkolások és egyéb brutális eljárások. (Horne [2006] 101. és 112. o.) Idővel a mérsékeltek és a muszlim civilek is célponttá váltak. (Horne [2006] 119-123. o.) A felkelés sajátossága, hogy kiterjedt városi karaktere is volt - elsősorban az algíri csata tette ezt az aspektust híressé -, és az erőszakos módszerek mellett békés szubverzív módszereket is alkalmaztak.

A francia felkelésellenes megközelítés politikailag nem volt rugalmas. Elutasították a politikai reformokat, ami a liberális ellenzéket hiteltelenné tette, így a radikálisoké lett a főszerep, amit az is erősített, hogy több mérsékelt párt vezetőit letartóztatták. A francia politikai vezetés kezdetben rendteremtő akciónak fogta fel az Algériában történteket, engedménnyel és reformkísérletekkel akkor jöttek elő, amikor már nem lehetett hatásuk. (Horne [2006] 96-98. o.) 
Nyílt titok volt, hogy a konfliktus alatt a francia katonai egységek kínozták a foglyaikat. Bár a vezetés véleménye megoszlott, és sok ellenzője volt, ez keveset változtatott a gyakorlaton. 1955-ben született egy kormányzati jelentés, a Wuillaumejelentés, amely a kínzás részleges legalizálása mellett foglalt állást. Ezt azzal indokolták, hogy egyrészt már általános gyakorlattá vált, másfelől pedig hatékonynak bizonyult sok fenyegetés elhárításában, így a maradandó egészségkárosodást nem okozó módszerek legalizálása indokolt. Az elfogadására nem került sor, de az akkor uralkodó hangulatot és a hozzáállást jól érzékelteti. (Horne [2006] 195-198. o.) A kínzás végső soron jelentős hibának bizonyult. Amellett, hogy sok téves információhoz vezetett, ami lelassította a hírszerzési rendszert, sokakat az ellenség táborába hajszolt, és kitűnő propagandaeszközt adott az FLN kezébe. Franciaországban is nagy felháborodást keltettek a kínzásokról szóló hírek. (Horne [2006] 203-205. o.)

A francia tisztikar vezető pozícióban lévő tagjai karrierjük elején megérték a megalázó világháborús vereséget, nem sokkal az algériai háború előtt kénytelenek voltak beletörődni az indokínai, tunéziai (és később a marokkói) gyarmat elvesztésébe. Nem akartak átélni újabb veszteségeket, el voltak kötelezve Franciaország területi egységének megőrzése mellett. (Horne [2006] 174-178. o.) Ez áll a hadsereg brutális fellépésének hátterében.

A konfliktus leghíresebb periódusa az utóbb algíri csataként elhíresült szakasz volt. Az FLN bombamerényletekkel és más fegyveres akciókkal kívánta a világ előtt aláásni a fővárosban a francia jelenlétet egy titkos szervezet segítségével. Az összecsapás nyitányát a telepesek által látogatott szórakozóhelyek elleni bombamerényletek jelentették, melyekre a francia hatóságok és a telepesek is erélyesen reagáltak, ami erőszakspirált indított el. Miután a civil hatóságok képtelenek voltak ezen úrrá lenni, a 10. ejtőernyős hadosztály kapta a feladatot a rend helyreállítására. Parancsnoka, Jacques Massu tábornok lett felelős a város biztonságáért. Massu egységei mindent megtettek a rend helyreállítására, beleértve az FLN által elrendelt általános sztrájk erőszakos letörését is. A brutális, ám hatékonynak bizonyuló fellépés az ALN szervezetének szétesését eredményezte több hónapnyi rendkívüli feszült időszak után. (Horne [2006] 184-194. o.)

A franciák egyre sikeresebben léptek fel, de a háború és annak emberi, politikai, gazdasági és egyéb ára az otthoni politikai támogatást nagymértékben csökkentette. A negyedik köztársaság politikai instabilitása ezt a helyzetet csak rontotta. A de Gaulleféle fellépés pedig odáig vezetett, hogy Franciaország elismerte Algéria függetlenségét, 
mivel nem volt hajlandó több áldozatot vállalni érte. Mindez annak ellenére történt így, hogy a felkelés nagyon messze állt attól, hogy lényeges területen érjen el katonai sikert. Ez pedig az Algériában állomásozó francia egységek egy részének lázadásához vezetett, valamint az OAS tevékenységének megindulásához.

\section{Különleges kezdeményezések és szervezetek Algériában}

Polgári és katonai területen egyaránt voltak figyelemreméltó és szokatlan kezdeményezések a függetlenségi háború alatt.

Az Arab Iroda mintájára a francia hatóságok létrehozták a Speciális Adminisztratív Egységek (Section Administratives Specialisées, SAS) rendszerét. A vidéki igazgatás jelentős gondokkal küszködött, mivel a mérete nem volt megfelelő az igényekhez képest. Az SAS a hadsereg vezetése alatt müködött, annak állományából szerveződött. Támogatására szociális központokat (centres sociaux) hoztak létre, melyek feladata támogatás nyújtása volt az arabok lakta elmaradott területeknek. Egy sor reform meghozása mellett jött létre, melyek célja a muszlim lakosság helyzetének javítása volt. (Horne [2006] 108-110. o.) Az SAS a katonai jellege miatt képes volt a hadsereg támogatásával a civil közigazgatáshoz képest jobban koordinálni a politikai és a katonai müveleteket. A rendszerét természetesen nemcsak közigazgatási feladatok ellátására használták fel, hanem a helyi hatalmi viszonyok befolyásolására is, pl. az idősek befolyásának erősítésére a fiatalabb radikálisok kárára. (Horne [2006] 165-167. o.)

Bár nem az algériai konfliktus hívta életre, mindenképpen említést érdemel a 11. Shock zászlóalj, amely a hadsereg és az S.D.E.C.E., a francia hírszerzés közös egysége volt. Ez tette meg az algíri csatában a döntő lépést azzal, hogy a biztonsági szolgálattól átvett anyagok alapján hatalmas letartóztatási hullámot készített elő minden jogi szempontot figyelmen kívül hagyva. (Horne [2006] 189-190. o.) Később az egység egy tisztjének kezdeményezésére kezdtek el kidolgozni a franciák egy finomabb beszivárgási eljárást, amelynek lényege, hogy átállt felkelőket küldtek vissza a volt társaikhoz, és a segítségükkel elfogták vagy megölték a vezetőket. (Horne [2006] 212. о.)

A városi erőszak elhárítására több szervezetet is létrehoztak. Ilyen volt a Városi Védelmi Harccsoport (Dispositif de protection urbaine, D.P.U.), ami Roger Trinquier irányítása alatt állt. A szervezet gyakorlatilag a lakosság soraiból toborzott informátorok 
segítségével igyekezett felderíteni az ellenséges szubverzív szervezetek felépítését. Trinquier a már említett munkájában a D.P.U. szervezését írta le könyvének a lakossági szervezetről írott részében. Egy másik fontos innováció a francia fellépés szempontjából a Müveleti Védelmi Különítmény (Détachement Opérationnel de Protection, D.O.P.), amely az együttmüködni. nem hajnaladó gyanúsítottak vallatását végezte. Változatos módszereket alkalmazott, melyek vége nem ritkán a kínvallatás volt. (Horne [2006] 198-199. о.)

\section{Forradalmi hadviselés doktrína}

A forradalmi hadviselés doktrína (Doctrine de la guerre révolutionnaire, DGR) a második világháború utáni francia felkelésellenes elmélet elnevezése. Charles Lacheroy tekinthető az iskola alapítójának, aki szerint a forradalmi háború nem a gerilla háború vagy a kis háború másik elnevezése, hanem a totális háború legmagasabb formája, ami magyarázza, hogy a látszólag erősek miért szenvednek vereséget a látszólag gyengéktől. Szerinte a forradalmi hadviselés stratégiájának célja a hátország, vagyis a lakosság feletti irányítás megszerzése. Bár az iskola tagjai között a gyarmati gyakorlat felhasználhatóságának, a kommunista ideológia mozgósító erejének és az irányítás és részvétel közötti egyensúly kérdésének kapcsán sok vita volt, kétségtelen, hogy a második világháború utáni francia felkelésellenes tapasztalatok taktikai és hadműveleti szinten a mai napig relevánsak, és különösen Roger Trinquier és David Galula munkáján keresztül hatnak.

Érdekes sajátosság, hogy a DGR élharcosai hasonló életutat jártak be: a gyarmati ezredekből vagy az idegenlégióból érkeztek, ellenállóként vagy különleges müveleti egység tagjaként részt vettek a második világháborúban, Indokínában vagy Algériában - esetleg mindkét helyen - szolgáltak, többnyire középvezetői pozícióban. Annak a generációnak a tagjai voltak, amelynek a totális háború és a vereség volt a meghatározó élménye. Fontos volt számukra a birodalmi eszme, az algériai vereséget ezért nem tudta elfogadni sok DGR mellett elkötelezett tiszt.

A DGR irányzat tagjai mind hadműveleti, mind taktikai szinten sok fontos megállapítást tettek a sikert illetően. Ezek közé tartozik például, hogy hadmüveletet csak abban az esetben szabad végrehajtani, ha a pacifikáció célját szolgálja; az olajfolt taktika minden szinten fontos; a sikeres pacifikáció magában foglalja a lakosság bevonását a saját védelmébe, illetve minden rendelkezésre álló eszközt megfelelően kell 
kombinálni és összehangolni a siker érdekében. A legfontosabb megállapítás talán az, hogy a lakosság és az ellenség szétválasztása fontos szempont nemcsak fizikailag, hanem politikailag is, ezért a felkelőhöz hasonló szervezetre van szükség a politikai mozgósítás céljából, ami szükségessé teszi a civil szervekkel való szoros együttmüködést. A parancsnoki irányítási viszonyokat illetően a helyi parancsnokokat helyezték elötérbe. A különleges erőknek és a pszichológiai műveleteknek jelentős szerepet szántak.

A taktikai siker előfeltételének tekintették a megfelelő létszámfölényt és a müveleti relevanciával rendelkező aktuális hírszerzési információk rendelkezésre állását megfelelő mennyiségben és minőségben. A végrehajtásban számos jól bevált taktikát alakítottak ki, mint a quadrillage, a helyi specializált erők (harkas, GAD stb.) és a nomadizáció. Felismerték a lakosság fontosságát, hangsúlyozták a megfelelően képzett helyi biztonsági erő és a hosszú távú műveletek szükségességét.

A DGR vezető tagjai taktikai, intézményi és szervezeti kulturális változást akartak elérni a francia hadseregben annak érdekében, hogy a pacifikáció és a szubverzióellenes megközelítés legyen elsődleges. Javaslataik megosztották a francia hadsereget. A gyarmati egységek katonái pl. a pszichológiai müveletek hatásában nem bíztak, és klasszikus módokon (gazdaságfejlesztés, humanitárius segítség stb.) próbálkoztak a lakosság lojalitásának biztosításával - ennek egyik eredménye volt 1955-ben az SAS létrehozása.

A DGR-megközelítésnek több sajátossága is volt. Egyfajta abszolút realizmus jellemezte taktikai és hadmüveleti szinten, ami a politikai-ideológiai jelleg fontosságának felismerését, a célok és eszközök megfelelő kezelését illette. Ezt azonban az a sajátosság kísérte, hogy az erős antikommunizmus és a szubverzió kérdésével kapcsolatos megszállottság leszükítette hívei látókörét, így a politikai realitásokat helyi és otthoni viszonylatban is félreértelmezték. A legnagyobb hiba az otthoni politikai támogatás jellegének félreértelmezése volt, amennyiben a felkelők politikai-katonai értelemben véve totális háborújára totális háborúval akartak válaszolni, nem véve tudomást arról, hogy a francia közvélemény ezt nem támogatja. Nem ismerték fel, hogy közvetlen fenyegetés hiányában a politikai támogatás korlátozott: a francia politikai elit a világforradalom elleni harcot nem tekintette létfontosságúnak, a katonai elit viszont igen.

A politikai szándékok félreértelmezése azonban nem vákuumban történt. Francia részről nem fogalmaztak meg semmilyen életképes, vonzó alternatívát a helyiek részére, 
ami politikai téren feléjük billenthette volna a mérleg serpenyőjét. Így a hadsereg egy relatív politikai vákuumban müködött, és a civil-katonai kontroll elmozdult a megszokott helyéről. A történtek így részben a francia politikai vezetés hozzáállására is visszavezethetök.

A DGR-nek a hivatalos francia doktrínára hosszú távon nem volt jelentős hatása. De Gaulle alatt a francia erők a klasszikusabb vonalak mentén rendeződtek vissza. Az 1961-es sikertelen puccs erre csak ráerősített. Az egész téma tabuvá vált a későbbiekben, közvetve azonban a mai napig hat. A latin-amerikai felkelésellenes müveleteknél a francia segítség sokszor a DGR elméletei mentén történt, az ott tapasztalható brutális fellépés pl. ide is visszavezethető. A gyarmati ezredek (regiments coloniaux) túlélték ezt a nehéz időszakot, lényegében csak a nevüket változtatták meg gyalogsági (infanterie) vagy tengerészgyalogsági tüzér (artillerie de marine) ezredre. (Durand [2010] 17-22. o.)

A DGR-nek nem sikerült a katonai és politikai dimenziókat megfelelően összehozni, így annak ellenére, hogy taktikailag képes volt jelentős sikereket felmutatni, a gyakorlatban bukásra volt ítélve. Az algériai háború erre bizonyíték. A hasonló jellegü konfliktusoktól mára kölcsönös az idegenkedés a politikai és a katonai vezetésben is. Demokratikus rendszerekben a hadsereg általában nem szeret „piszkos” háborúkba belemenni, a politikai vezetés pedig nem hajlandó vállalni azokat a feltételeket, amelyek mellett a hadsereg képesnek érezhetné magát egy ilyen háború sikeres megvívására.

\section{Felkelésellenes alapmüvek}

\section{Roger Trinquier: Modern hadviselés}

Roger Trinquier, aki Indokínában és Algériában egyaránt fontos pozíciókat betöltő tisztje volt a francia gyarmati haderőnek, a Modern hadviselés címü, először 1961-ben kiadott munkájában összegezte az általa levont tanulságokat, illetve azokat az elméleti és gyakorlati teendőket, amelyek szerinte szükségesek a felkelők legyőzéséhez. A szubverzió és a gerilla hadviselés által jelentett kihívás jellemzésére vezette be a modern hadviselés fogalmát. Nézete szerint a hadviselés egy új fejlődési szakaszhoz érkezett, amivel a francia hadseregnek szembe kell néznie. 


\section{A lakosság szerepe}

Trinquier kiindulópontja az, hogy a modern konfliktus az ország egész lakosságát érinti egyrészt az ellenséges igények, másrészt a biztonsági erők fellépése miatt. Fontos, hogy a kormányoldal egyértelmüen ismertesse a lakossággal a céljait. Tudniuk kell, hogy a kormányoldal jó ügy érdekében harcol. A folyamatban lévő müveletek alatt arra kell törekedni, hogy a lakossággal megértessék a meghozott lépések értelmét, a rend helyreállása után pedig arra, hogy milyen problémákat kell megoldani a teljes normalitás eléréséhez. Ehhez a leghatékonyabb eszköz a lakossági szervezet. (Trinquier [1985] 49-50. o.)

\section{A lakossági szervezet}

Trinquier elsődleges szempontnak tartotta a lakosság védelmét a felkelők befolyásától és erőszakos cselekményeitől. Nézete szerint az állampolgár a legfontosabb faktora a konfliktusnak, akit mindkét hadviselő félnek - az államnak és a felkelőnek is állásfoglalásra és lehetőleg harcra kell bírnia a győzelem érdekében. Ennek kapcsán egy ellenszervezet létrehozására, gyakorlatilag a felkelőknél bevált szervezeti struktúra átvételére tett javaslatot. A szervezet célja az ellenséges szubverzív szervezet tagságának felderítése. A megvalósításhoz hűséges vezetői gárda kell, amely a lakóhelyén bizalmi alapon, titokban kezdi kiépíteni a szervezetet minimális állami segítséggel. Házakig, házcsoportokig menően kell felelősöket találni a szervezetbe, akik minden szokatlan tevékenységről beszámolnak.

A szervezésben a rendőrség korlátozott szerepvállalását is lehetségesnek tartotta. A hatékony szervezéshez szerinte elengedhetetlen egy összeírás végrehajtása - melynek során minden számba vett személynek személyazonosítót lehet és kell adni -, amikor rögzítik a lakók adatait és a családfőt teszik meg felelőssé minden változás azonnali bejelentéséért. Ennek kapcsán kell kijelölni a megfigyelési egységeket és azok felelöseit, ezt követően a rendőrség segítségével felfelé lehet majd építkezni. Létre kell hozni a lakossági szervezetek központi koordináló testületét, amit ő Lakossági Szervezet és Kontroll Irodájának nevez. Ez a szervezet szükség esetén segítséget nyújthat a hatóságoknak az élelmiszer, az állatok, az egyéb ellátmány, illetve minden felhasználható erőforrás feletti irányításra. (Trinquier [1985] 29-34. o.) 


\section{Hírszerzés}

Hatékony hírszerzéssel nagymértékben csökkenteni lehet a beszivárgás problémáját, és azonosítani lehet az ellenséges szervezet kulcsfontosságú vezetőit is. Ennek érdekében egy az egész országra kiterjedő szervezet létrehozására tett javaslatot, amelynek komoly nehézségekkel kell majd szembenéznie a szubverzív szervezet felderítésében, mivel a helyi forrásokat jó eséllyel megfélemlítik. A problémák áthidalására egy sürü informátori hálózat kialakítását javasolta, amelynek hatékony és fennakadások nélküli müködéséhez kiképzőtáborok kellenek, ahol a megbízható állampolgárokat gyorsan ki lehet képezni a szükséges feladatokra. Trinquier szerint a társadalom teljes behálózása a cél. Egy ilyen méretű szervezet segítségével az ellenséges szubverzív szervezet alján elhelyezkedő, a lakossággal érintkezésbe kerülő tagokat könnyen és gyorsan lehetne azonosítani.

A beérkező információk gyors hasznosítása érdekében akciószolgálatot kell létrehozni a rendfenntartó erők soraiból, melynek feladata az ellenséges szervezet elpusztítása. Ennek érdekében szorosan együtt kell müködnie más hasonló tevékenységet végző szervekkel, elsősorban a rendőrséggel. Az akciószolgálat további feladata, hogy az ellenséges vezetés azonosított tagjait titokban letartóztassa és meggyőzze az átállásról. (Trinquier [1985] 35-39. o.)

\section{Városi müveletek}

Trinquier az algériai tapasztalatai alapján a rendőrségnek kiemelkedő szerepet szánt a városi müveletekben. Fontosnak tartotta, hogy a lakossággal el kell fogadtatni a hatósági fellépést, és meg kell tervezni egy stabilizációs programot, amely a lehető legnagyobb mértékben biztosítja a lakosság normális életkörülményeit. Ha a rendőrség nem képes megbirkózni a kihívással, segít neki a hadsereg, amely át is veheti tőle a feladatot. A hadsereg és a rendőrség együttmüködésével kialakításra kerülő biztonsági háló feladata, hogy korlátozza a felkelök mozgását és végső soron hozzájáruljon a szervezet felszámolásához. A müveletek sikeréhez a biztonság megteremtése az elsődleges, mert addig nem lesznek információk a lakosság irányából, amíg az együttműködők biztonságát nem tudják garantálni. A lakossági szervezet tagjait, illetve a hírszerzés munkatársait is meg kell védeni. 
A korai müveletekben a kisebb települések vagy városrészek lakosságát tömegesen kell kihallgatni, egymástól elkülönítve, célzott kérdésekkel, amelyeknek a vezetők személyére kell irányulniuk. A sokszor említésre kerülő személyeket le kell tartóztatni és alaposabb kihallgatásnak alávetni. Trinquier szerint probléma, hogy a kormányoldalt támogatók között is ellenérzést és olykor ellenállást váltanak ki a rajtaütések, mivel a lakosok általában nem értik meg a konfliktus jellegét. A börtönök hamar meg fognak telni, és a várható nehéz körülmények, melyeket a foglyoknak el kell viselniük, az ellenség propagandáját fogják erősíteni. Ennek elkerülése érdekében a genfi egyezmények szerinti fogolytáborokat kell felállítani.

Mivel a harctér a lakosság soraiba tevődik át, és a harc a nyilvánosság előtt zajlik, bizonyos brutális jelenetek a lakosság szeme láttára történnek. Elkerülhetetlen, hogy ártatlan polgárokat is kihallgassanak vagy átkutassanak. Olyan harci cselekményekre kerülhet sor, melyeknek a polgárok a szenvedő alanyai. - Mindezek kapcsán az ellenség mindent meg fog tenni, hogy az ellenérzést kihasználja és a maga javára fordítsa. Ezért a fegyelem maximális fenntartására van szükség, és mindenáron el kell kerülni az önkényes erőszak alkalmazást. A hadseregnek a törvényekhez kell igazodnia. A rendőri fellépés is katonai műveletként fog müködni, és addig nem szabad véget érnie, amíg az ellenséges szervezet felszámolásra nem kerül, illetve a hírszerző szervezet és a lakossági szervezet fel nem épül. (Trinquier [1985] 43-49. o.)

\section{Gerillaellenes stratégia}

Kellő méretü, idejű és intenzitású műveleteket kell végrehajtani annak érdekében, hogy a gerillacsoportokat fel lehessen számolni. Ez alapos felkészülést és hatékony irányítást feltételez. A nagy területre kiterjedő felkelés, a katonai-politikai döntések meghozása és az együttmüködés a polgári állami szervekkel szükségessé teszi, hogy a legmagasabb parancsnoki szintek a műveletek minden fázisában részt vegyenek. (Trinquier [1985] 92-93. o.)

Fontos a várost a gerilla menedékhelyével összekötő katonai-politikai szervezet elpusztítása, amely az ellátmányt és az információkat biztosítja a fegyveres csoportoknak. Pusztulásával a megmaradt elemek a menedékterületre (nehezen megközelíthető, a gerillák menedékeként szolgáló vidéki terület) kényszerülnek visszavonulni, ahol nélküle nem fognak tudni megfelelően védekezni. A legsebezhetőbb pont az ellenséges szervezetben a városi szervezet, amely többnyire a hatóságok 
irányítása alatt maradt területeken müködik. Az összekötő szervezet elleni siker vissza fog vezetni a városi szervezethez. (Trinquier [1985] 71-72. o.)

Trinquier rámutatott, hogy a gerilla lakosságtól és tereptől függése a keresett gyenge pont. Rá kell kényszeríteni, hogy feladja a választott terepét, ezért el kell vágni az utánpótlásától. Az élelem nagyobb gyengéje, mint a lőszer, ezt az utánpótlását kell támadni. A fegyveres csoportok fokozott veszteségei a lakosság feletti kontroll fokozatos csökkenését fogják eredményezni. Végső lépésként el kell érni, hogy a lakosság a saját védelmét legalább részben el tudja látni. (Trinquier [1985] 64. o.) Ennek megvalósításához a quadrillage nevet viselő taktikát javasolta.

\section{Quadrillage (,rácsozás”)}

A felkelő tevékenység a rendőri erőket visszaszorítja a jobban védhető területekre, ahol fegyveres konvojok segítségével létesítenek kapcsolatot a védett területek között. Ennek figyelembe vételével egy védelmi rácsszerkezet kialakítására van lehetőség, ahol a katonai szervezet a polgári közigazgatás határait követi, hogy a lehető legjobban kihasználják az elérhető erőforrásokat és lehetővé tegyék a normális igazgatási müködést.

Meg kell határozni, hogy az ellenség szervezete milyen területi egységre épül, és azon belül kell fellépni. A megtisztításra kiválasztott területen a települések körül örhelyeket kell létrehozni, amelyek védik őket a támadásoktól. A rendőrség feladata az ellenséges szervezet felgöngyölítése és a lakosság védelmének megszervezése. Folyamatosan növekedő védelmi határokat kell kitűzni, és idővel a környező falvakat is be kell vonni, az emberek és javak áramlását pedig szigorúan szabályozni kell. Az ellenséges katonai-politikai szervezet megsemmisítését az teszi lehetővé, hogy annak helyben kell maradnia.

A gyéren lakott, nehezen védhető területeken, amelyek az ellenséges fegyveres csoportok átmeneti búvóhelyéül szolgálhatnak, mobil egységekre kell támaszkodni. Egy faluban legalább egy hétre van szükség az ellenséges politikai-katonai szervezet elpusztításához. A fegyveres csoportok elpusztítsa után az ott élő lakosságot stratégiai falvakba kell költöztetni és felügyelni. Eközben el kell kezdeni a saját hírszerzési és védelmi háló kiépítését, meg kell szervezni és végre kell hajtani a lakosság összeírását. A lakossági szervezet kiépítése is megindul. A jelen nem lévő családtagokat gyanúval kell kezelni, akik utólag kérnek személyazonosítót a településen, csak alapos 
háttérnyomozás után kaphatják meg. A quadrillage végrehajtása nagyobb területeken komoly logisztikai elökészítést igényel. Ki kell jelölni, hogy mely pontokat kell megszállni, és figyelembe kell venni az útvonalak nyitva tartásának szükségességét. (Trinquier [1985] 72-80. о.)

Az ellenséges menedékterület bekerítése nem lineáris lesz. A csapatok a folyamat közben megismerkednek a tereppel, ahol olyan zónákat kell kialakítaniuk, amelyekben azonnal érzékelni lehet az ellenséges csoportok mozgását, hogy azonnal meg lehessen öket támadni. Miután a bekerítés megtörtént, a beavatkozó eröket be kell juttatni a területre, és támadást kell indítani.

Fontos, hogy a védelmi és a támadó erők az újra csoportosulni próbáló gerilla erőket felderítsék és éjszaka megtámadják. Éjszaka minden olyan civilt, aki nem rendelkezik azonosító kártyával, gyanúsítottként kell kezelni. Mindent, amit a gerillák fel tudnak használni és nem védett területen van, el kell pusztítani vagy el kell szállítani. Lehetővé kell tenni, hogy a magukat megadni kívánó ellenséges fegyveresek ezt megtehessék. A lakosság és javak áramlásának szabályozását ellátó intézkedéseknek egészen addig meg kell maradniuk, amíg az ország egész területén helyre nem áll a béke. (Trinquier [1985] 82-86. o.)

Ahol a rácsok között van hely, ott a lakosság ki van téve a felkelőknek. A városok és stratégiai falvak megszervezése lehetővé teszi a lakosok számára, hogy megszervezzék a saját védelmüket, így csapatok fognak felszabadulni más területekre. (Trinquier [1985] 75. o.)

Az erők jellegét tekintve Trinquier három feladatot különböztetett meg:

- Rácserők: feladatuk a városok, kis és közepes települések védelme. Hatékonyságuk attól függ, hogy a rácserőt képező egységek képesek-e elpusztítani a településen az ellenséges szervezetet, és képesek-e hatékonyan irányítani az emberek és javak áramlását - amitől a beavatkozó erők periférián végrehajtott müveleteinek sikere elsősorban függ. Rendőri jellegü müveleteket kell végrehajtaniuk a lakosság érzékenységének figyelembe vételével, idővel rendőri erők váltják őket.

- Köztes erők: jól képzett egységek, amelyek az ellenség katonai-politikai szervezetének az elpusztítására szakosodnak a vitatott vidéki területeken. Az elszórtan élő lakosság áttelepítése és megszervezése is a feladatuk. Sokáig képesek messze a bázisaiktól élni, képesek nagy területen szétszóródni és 
rendőri müveleteket mélységben végrehajtani. Gyorsan képesek újracsoportosulni, ha jelentős harcérintkezés alakul ki ellenséges erőkkel.

- Beavatkozó erők: elit csapatok, amelyek képesek az ellenséges fegyveres csoportokat és bandákat a nehezen megközelíthető menedékterületükön megtámadni és elpusztítani. (Trinquier [1985] 90-91. o.)

\section{Hibák a gerillák elleni harcban}

A hadsereg számára probléma, hogy a hagyományos kereteken kívül és a legerősebb fegyverek mellőzésével kell erőszakot alkalmazni. Vannak téves felfogások, amelyek akadályozzák a felkelők elleni hatékony fellépést. Az egyik ilyen tévhit, hogy a hadseregnek a fegyveres csoportokkal szemben kell fellépni, minden mást a rendőrségre kell hagyni. A rendőrség békeidőben alkalmas a lakosság védelmére, de nincs felkészülve olyan ellenséges szervezet elleni fellépésre, amelynek célja az ország irányításának megszerzése és új rezsim létrehozása.

Másik tévhit, hogy a gerillát le lehet győzni a saját fegyvereivel. Ez az ellengerilla stratégia, amely a gerilla fegyverei és a reguláris hadsereg fegyverei közötti jelentős különbség figyelmen kívül hagyására épül, Indokínában és Algériában is kudarcot vallott. Az alapvető zavar a gerilla erők és a konvencionális erők potenciáljának meg nem értéséből fakad. A klasszikus eljárások (katonai őrhelyek, autonóm kommandó csoportok vagy járörök örhelyekröl kiküldve, lesállások, széleskörü kutatóakciók stb.) a lakosság támogatása nélkül csak korlátozott sikerekre képesek, és sokszor a katonai őrhellyel rendelkező falvak is ellenséges irányítás alatt állnak. A hadsereg hagyományos nehézfegyverzete és az annak biztosításához szükséges erőforrások a felkelők elleni küzdelemben nem jelentenek segítséget. A könnyüfegyverzetü ellenség képes a lakosságot a nehézfegyverekkel rendelkező erők megtámadása nélkül is irányítani, néhány erőszakos cselekmény elegendő lehet erre a célra. Az őrhelyeket az ellenség könnyen meg tudja figyelni, egyetlen elönyük, hogy egyfajta kötelezettséget teremtenek a hadsereg irányából a közösség felé a védelemre. Amíg az ellenséges katonai-politikai szervezet nincs elpusztítva, addig a gerillaellenes müveletek csak korlátozott sikereket érhetnek el, a pacifikációban nem lesz elörelépés.

Azt sem veszik sokszor figyelembe, hogy a hadsereg kiküldött egységei csak korlátozott ideig képesek kint tartózkodni, mert nem rendelkeznek azzal a támogató apparátussal, amivel a gerillák. Ráadásul a művelet sokkal megterhelőbb a kormányerők 
számára a nagyobb bizonytalanság miatt. A hadsereg ugyanis kénytelen érintkezni a lakossággal, melynek soraiban jelen vannak az ellenséges felderítés tagjai, és így folyamatosan tartani kell egy esetleges támadástól. További hiba, hogy sokszor nagyarányú müveletekkel próbálkoznak, amelyeknél a meglepetés még a legjobb parancsnokok irányítása mellett sem valósulhat meg, és így a siker esélye minimális.

A fentebbiek mind tipikus példái a konvencionális mentalitásnak. A tisztek általában a konfliktus katonai dimenziójához kötődnek, vagyis a gerilla csoportok hadszíntéri üldözését és elpusztítását tüzik ki célul. A parancsnok ilyen esetben mindig abban reménykedik, hogy gyors és látványos sikert érhet el. Ugyanakkor csekély érdeklödést mutat a lakossággal való óvatos együttmüködésre, ami miatt a gerilla csoportok túlélhetik a taktikai vereségeket. Csak a hosszas jelenlét vezethet sikerre, ami lehetővé teszi rendőri akciók végrehajtását. A konvencionális erő feladata, mivel nyílt vereségtől nem kell tartania, a fontos célok biztosítása. (Trinquier [1985] 51-59. o.)

\section{David Galula: Felkelésellenes hadviselés. Elmélet és gyakorlat}

David Galula is a szolgálatban szerzett tapasztalatait összegezte, illetve gondolta tovább. Harcolt a második világháborúban, megfigyelőként jelen volt a kínai polgárháborúban, ENSZ megfigyelőként a görög polgárháborúról is személyes tapasztalatai voltak, öt évig katonai attasé volt Hong Kong-ban és két éven át Algériában harcolt, ahol a 45. gyarmati gyalogsági zászlóalj egyik századparancsnoka volt. A véleménye sok vonatkozásban megegyezik Trinquier-ével. A legfontosabb különbség köztük, hogy Galula nem tüzte ki célul a lakosság feletti totális kontrollt.

A munka a gyarmatokon folyó harcokból levonható tanulságok rögzítése és rendszerbe foglalása mellett a francia felkelésellenes elképzelések fejlődéstörténetének feldolgozása. Terminológiája sajátos: szubverzió helyett - amikor a felkelő tevékenysége legális és erőszakmentes - a hideg forradalmi háború kifejezést használja, és ennek párjaként forró forradalmi háborúnak nevezi a fegyveres harcot, amikor nyíltan illegális és erőszakos a felkelő fellépése. (Galula [1964] 47. o.) Az egyöntetűség kedvéért mi helyettük a szubverzió és a felkelés kifejezést alkalmazzuk.

A forradalmi háborút a francia iskolának megfelelően definiálja: „Elsősorban belső konfliktus, bár külső erők csak ritkán nem befolyásolják. A felkelök ugyan sok esetben egyszerüen azonositható nemzetiségi csoportok (...) ez nem befolyásolja a stratégiailag fontos tényezőt, miszerint a helyi uralkodó hatalmat hívják ki maguk ellen, 
amely a létezö adminisztratív apparátust, hadsereget és rendörséget irányítja." (Galula [1964] 3. o.)

Elméletének legfontosabb jellemzője a lakosságközpontúság. A győzelmet ennek megfelelően így definiálja: „Ha a felkelőknek sikerül elválasztaniuk a lakosságot a felkelésellenes eröktöl, és képesek fizikailag kontrollálni és aktív támogatást kapni töle, akkor meg fogják nyerni a háborút, mert végsö soron a hatalom gyakorlása a lakosság hallgatólagos és aktív támogatásától függ, vagy legvégső esetben az engedelmességétől. Ezért a lakosságért folytatott harc kiemelkedö vonása a forradalmi háborúnak." (Galula [1964] 6. o.) Ennek fényében a háború célját alapvetően politikainak tartja, a felkelésellenes erő célja a maga oldalán tartani a lakosságot, vagy legalább az engedelmességét megtartani. Ez egyet jelent egy régi európai tradíció, a katonai és politikai elemek hadszíntéri elválasztásának felrúgásával, és a politika a katonai műveletek mozgatórúgójává válik. Ezt figyelembe véve a felkelő a konfliktus kezdetén előnnyel indul. A felkelő szervezetek ennek az igénynek a szem előtt tartásával szerveződnek, hiszen a fegyveres csoportok a párt vagy mozgalom fegyveres erejét jelentik. Állami szinten a politikai lojalitások távolról sem ennyire egyértelműek. (Galula [1964] 7. o.) A felkelésellenes erőnek ráadásul egymásnak ellentmondó prioritásokat kell szem előtt tartani és a legjobbat kihozni abból: egyidejűleg kell a lakosság és a gazdaság védelmét, a felkelők elleni offenzív fellépést és a szükséges politikai-katonai koordinációt végrehajtania. (Galula [1964] 10. o.)

\section{Szubverzió elleni fellépés közvetlen és közvetett megközelítése}

A közvetlen megközelítés lényege, hogy meg kell akadályozni az ellenséges mozgalom apparátusának kiépítését. A kulcsfigurák a szerveződő felkelés vezetői, akik letartóztatásával, mozgásszabadságának korlátozásával, szervezetének betiltásával stb. a felkelésellenes erő jelentős sikereket érhet el. Demokratikus környezetben ennek vannak akadályai, de ha már vannak rendkívüli törvények, akkor ez nem probléma. Problémát jelenthet, hogy a korai szakaszban való fellépés ráirányíthatja a nyilvánosság figyelmét olyan felkelő szervezetekre, amelyek népszerü követeléseket tűztek a zászlajukra.

Ha a felkelésellenes erőnek nincs különleges felhatalmazása, akkor azt kockáztatja az erélyes fellépéssel, hogy a jogorvoslat révén szereplési lehetőséget ad a felkelőknek. Ha túlzásba viszi a korai fellépést, azzal a saját belső ellenzékét erősíti. A közvetlen megközelítés akkor hatékony, ha a felkelö okának kicsi a vonzereje, a 
felkelésellenes erőnek megvannak a jogi keretei a fellépésre, és meg tudja akadályozni, hogy a felkelők széles sajtónyilvánosságot kapjanak.

A szubverzió elleni fellépés közvetett megközelítését vizsgálva a legolcsóbb megoldás rövidtávon a kormány gyengeségeinek javítása, pl.: a bürokrácia csökkentése, rendőrség és a fegyveres erők megerősítése.

Emellett tehet egyéb lépéseket is:

1. Beszivárgás a mozgalomba: a fiatal felkelő szervezet vezetése tapasztalatlan, így általában egyszerü beszivárogni és belülről bomlasztani. Minél tovább képes túlélni a szervezet, annál hatékonyabban fog védekezni a beszivárgás ellen.

2. A politikai gépezet megerősítése: alulról építkező politikai mozgalom kialakítása, ami ellensúlyozza a nyílt ellenséges tevékenységet. (Galula [1964] 48-51. о.)

\section{A felkelésellenes müveletek stratégiája}

Egy kiválasztott ellenséges területen az alábbi lépéseket kell végrehajtani:

- az ellenséges fegyveres erő kiszorítása

- a visszaszivárgás megakadályozása

- a lakosság kontrollja

- az ellenséges politikai szervezetet elpusztítása

- új vezetés választása

- az új vezetés próbára tétele, helyi önvédelmi erők szervezése

- érett vezetők képzése és egy nemzeti szintü politikai mozgalom szervezése a részvételükkel

- a felkelők maradékainak megnyerése vagy elnyomása (Galula [1964] 59. o.)

A felkelésellenes erők feladatköreit illetően a katonai erőt két csoportba osztja:

- Kvázi konvencionális módon, támadó műveleteket végrehajtó mobil egységek.

- Statikus egységek, amelyek a lakosság védelmét látják el és a politikai müveleteket segítik. Jól kell ismerniük a helyszínt és annak problémáit. Területi parancsnokság alatt állnak, követik a mobil egységeket. A területi parancsnok irányítási jogkörrel rendelkezik a területén tartózkodó minden katonai erő felett. (Galula [1964] 68. o.) 
A győzelem a felkelésellenes hadviselésben a felkelő elszigetelése a lakosságtól. Az igazi siker viszont az, amikor a lakosság önszántából tartja távol a felkelőket. Ebből fakad, hogy a győzelem a felkelésellenes müveletekben csak indirekt lehet. (Galula [1964] 57. o.) Elérése érdekében négy törvényt fogalmazott meg és hat olyan „lépést”, amelynek szem előtt tartása szerinte nélkülözhetetlen a sikerhez.

Első törvény: A lakosság támogatása ugyanolyan fontos a felkelésellenes erő, mint a felkelő számára.

Második törvény: A támogatást egy aktív kisebbség segítségével lehet megszerezni.

Harmadik törvény: A lakosság támogatása feltételes.

Negyedik törvény: A próbálkozás intenzitása és az eszközök mennyisége létfontosságú. A hat lépés:

1. Az erők gazdaságos felhasználása: a térben és időben megoszló műveletek a felkelésellenes erők körültekintő bevetését igénylik ahhoz, hogy a felkelő erőket a vitatott és a menedékterületeikről ki lehessen szorítani.

2. Visszafordíthatatlanság: a fordulatot az jelenti, amikor a helyi közösségböl kiemelkedik egy vezetői réteg, amelyre hosszú távon lehet alapozni.

3. Kezdeményezés: a felkelésellenes erő választja meg, hogy hol lép fel aktívan a felkelő erő ellen. A lakosság körében való megfelelő fellépésből következhet, hogy a felkelö nem vonulhat vissza büntetlenül, és nem próbálhat meg kivárni.

4. A felkelésellenes erő rendelkezésére álló források maximális kihasználása.

5. Egyszerüség: olyan stratégia kidolgozására van szükség, amely a megvalósításán dolgozó heterogén csoportban mindenki számára érthető és végrehajtható.

6. Uralni annyit tesz, mint irányítani: a stabilan birtokolt területekröl a parancsnok megfelelő helyzetfelmérés után képes tervezni a felkelő területek pacifikálását. (Galula [1964] 55-63. o.)

\section{Műveletek iránya és az ellenok szükségessége}

A műveletek megkezdésére két lehetőség van:

1. A müveletek az ellenség által uralt területekre vannak koncentrálva, onnan lesznek kiterjesztve a vitatott és a kormányhü területekre. (Ez a leggyorsabb lehetőség, ha sikeres.) 
2. A kormányhü területekről kiindulva az ellenséges irányítás alatt álló területek felé terjeszkedés. (Ez lassabb, de kezdetben kevesebb erőforrást igényel.)

Elméleti lehetőségként még az ország teljes területén való kezdeményezés is rendelkezésre áll, ugyanakkor ennek gyakorlati kivitelezéséhez a legtöbbször nem áll rendelkezésre megfelelő mennyiségü és minőségü erőforrás.

A felkelésellenes erőnek a sikerhez egy megfelelő ellenokot is találnia kell. A felkelésellenes oldalnak általában csak másodlagos, kis mozgósító erejü okok maradnak, amiket a zászlajára írhat. A nagyarányú reformok nem jelentenek megoldást a felkelői oldal okainak megszüntetésére, mivel azokat általában csak az aktuális kormány bukásával lehetne elérni. Érdemes a lakossági fogadókészséget megvizsgálni a reformokat illetően, hiszen felkelésellenes oldal a nem kívánatos reformokkal a saját helyzetét nehezítené. Az óvatosság mindenképpen ajánlott, mert a felkelői oldal az ilyen lépéseket a maga győzelmének könyvelheti el, és újabb, merészebb követelésekkel is elöállhat. Azt is szem előtt kell tartani, hogy megvalósíthatóak legyenek a reformok, mivel a megvalósítás elmaradása komoly nehézséget okozhat a felkelésellenes oldalnak. A konfliktus első részében aránylag kevés szerepe van az ellenoknak, hiszen ekkor a félelem és az érzelmek a domináns tényezők, később viszont a kormányzati oldal mellett szólhat a konzekvens végrehajtás. (Galula [1964] 71. o.)

\section{Hírszerzés}

A hírszerzésnek Galula szerint komoly nehézségekkel kell megküzdeni, mivel a lakosság az alapvető információs forrás, de az addig nem fog együttmüködni, amíg nincs meg a kellő biztonságérzete. (Galula [1964] 53. o.) Ennek érdekében lehetőséget kell biztosítani azoknak, akik szeretnének együttmüködni, de félnek, ezért a személyazonosságuk nyilvánosságra kerülése nélkül szeretnének információkat átadni. Ehhez célszerü a lakossággal való kapcsolatkialakítási lehetőségek számát megsokszorozni. Érdemes azokat megkeresni, akik a felkelésellenes oldal győzelmével jól járhatnak, mert nekik külön motivációjuk van az együttműködésre. A pszeudo gerilla módszert is jó eljárásnak tartja a felkelők és a lakosság közötti kapcsolat megbontására, illetve a felkelők sorainak megzavarására. (Galula [1964] 86-87. o.) 


\section{Információs múveletek}

Az információs műveletek terén a felkelésellenes erőnek ragaszkodnia kell a tényekhez. A hazugság és a túlzás átmeneti sikert hozhat, de a lelepleződés elhiteltelenítheti a lakosság előtt. Az információs müveleteknek három célcsoportját határozza meg: a lakosságot, az ellenséget és a saját erőket. (Galula [1964] 11. o.)

\section{Adminisztratív dimenzió és koordináció a hadsereggel}

A lakosság irányítására négy struktúra szolgál: a politikai berendezkedés, a közigazgatás, a rendőrség és a hadsereg. Galula az alábbi feladatokat osztja szét a különböző szervek között.

Katonai feladatok:

1. a gerillák fó erejét elpusztítani

2. megakadályozni a visszatérésüket

3. védelmező helyőrségeket kell létrehozni

4. a gerilla egységek maradékait követni kell

Rendőri és igazságügyi feladatok:

1. azonosítani, letartóztatni és kihallgatni a felkelők politikai ügynökeit

2. bíróság elé állítani ezeket az ügynököket

3. rehabilitálni azokat, akiket át lehet állítani

Politikai müveletek:

1. a lakossággal való kapcsolatkialakítás

2. az irányító szabályok kidolgozása, bevezetése

3. helyi választások megszervezése és végrehajtása

4. az új vezetők kiválasztása és tesztelése

5. ezen személyek pártba szervezése

6. minden konstruktív feladat elvégzése, ami a lakosság megnyerését szolgálja

A győzelem a fenti tevékenységek közös eredménye, a siker érdekében közösnek kell lenni a vezetésnek is. Gyakori probléma, hogy a civil oldalon általában nem rendelkeznek a kellő számú és felkészültségű állománnyal a feladat megoldására, ezért sokszor a hadseregnek kell segítenie. Az alapelv azonban mindig az, hogy a politikai 
érdek az első. Mindig észben kell tartani, hogy a harc alapvető célja - a fennálló politikai berendezkedés túlélése - politikai cél.

Az irányítás jelenti a legnagyobb nehézséget. A fegyveres harc a katonák vezetésével vívható meg, de őket előtérbe helyezni a civil vezetés kárára a politikai célok leértékelését jelentené, sőt kudarc látszatát keltené. Az általános koordináló feladatot ezért a civil kormányzati infrastruktúrának kell ellátnia. (Galula [1964] 64-66. о.)

A megtisztítás alá kerülő területeken a hadseregnek jelentős civil feladatköröket kell ideiglenesen átvenni, ilyenek:

1. lakosság-összeírás

2. új szabályok betartatása a személyek és áruk forgalmát illetően

3. személyes szintü propaganda

4. hírszerzés az ellenséges politikai-katonai szervezettel szemben

5. gazdasági és szociális reformok végrehajtása

Ezeknek megfelelően kell felszerelni, ellátni és támogatni az ilyen céllal bevetett erőket. (Galula [1964] 69. o.)

Galula jelentős hangsúlyt helyez az oktatás szükségességére mind a katonai, mind a civil oldalon. Szerinte lehetővé kell tenni egy olyan vezetői réteg kialakulását, amely képes a feladatokat megfelelő hatékonysággal ellátni. Ennek érdekében egy közös civilkatonai doktrína kidolgozására is javaslatot tett, amely megteremt egy egységes terminológiát és elméleti hátteret, leegyszerüsítve a felek kommunikációját. (Galula [1964] 68-69. o.)

Az újonnan a felkelésellenes erők felügyelete alá került területeken nagy figyelmet kell fordítani a helyi vezetés létrehozására. Az egyik megoldás a korábban a kormánnyal együttmüködő személyek kijelölése, de ez csak a legvégső megoldás lehet, mivel legitimációhiány miatt nem lehet hosszú távon tervezni velük. Elönyösebb, ha természetes módon emelkednek ki. Annak a veszélye is fennáll, hogy olyanok lesznek megválasztva, akikről a helyeik úgy gondolják, hogy a felkelésellenes eröhöz füződő kapcsolataik miatt előnyösebben tudják képviselni a települést. Emiatt hangsúlyozni kell a szabad és titkos választások szükségességét és fontosságát, illetve a megoldás átmeneti jellegét.

Fontos, hogy az újonnan felálló vezetést teszteljék, aminek számos módja van. Ilyen az önkormányzat müködtetése, gazdasági és szociális projektek végrehajtása, 
önkéntesek toborzása stb. Az alkalmatlan vezetőket el kell távolítani, és új embert kell a helyükre választani. Galula három fö problémát azonosít a helyi vezetéssel kapcsolatban:

1. A megválasztott vezetők célpontok a felkelők számára, védeni kell őket, de olyan módon, hogy ne tünjenek a felkelésellenes erők bábjának.

2. A paternalizmus bizonyos fokát kezdetben nem lehet elkerülni, de minimalizálni kell, ideális esetben fel kell számolni.

3. A végrehajtandó feladatok logisztikai támogatást igényelnek, ami ismét a szükös erőforrások kérdését veti fel; azokat a területeket érdemes favorizálni, ahol a legaktívabb a közösség a felkelésellenes erő mellett.

Fontos lépés egy párt megszervezése, amely a felkelésellenes erök irányítása alatt álló területeken újonnan megválasztott vezetőket tömöríti országos szinten. Erre azért van szükség, mert a felkelők az országos szintü szervezettség miatt előnyben vannak a helyi politikában. A pártnak független programmal kell rendelkeznie, amelynek tartalmaznia kell a végrehajtandó reformok pontos meghatározását. (Galula [1964] 9296. o.)

\section{A felkelésellenes erő lehetséges hibái}

Galula alaposan körüljárja azokat a tévhiteket, amelyek szerint a felkelők módszereinek átvétele előnyt jelentene a kormányoldal számára. Rámutat, hogy a felkelő szervezet hadviselési módja arra van kitalálva, hogy a gyenge szervezet harc közben erősödjön meg. A felkelésellenes erő eredendő fölényben van, emiatt lehetetlen az ellenség taktikájának átvétele. A gerilla számára a biztonsági erők adnak célpontokat, ez fordítva nem működik. Továbbá, ha a felkelésellenes erő gerillaként müködne, akkor a lakosság aktív támogatásával kellene rendelkeznie a saját politikai szervezetének a segítségével. Ebben az esetben azonban nem lenne szükség az egész fellépésre. Ugyanez a helyzet a titkos csoportok szervezésével is, amelyek csak bővítményt képezhetnek a felkelésellenes szervezetben, a gyakorlati hasznuk pedig megkérdőjelezhető. A terrorizmus átvétele, ami a felkelő egyik leghasznosabb eszköze, a hatásában pontosan ellentétes azzal, amit a felkelésellenes erő meg akar valósítani, vagyis a biztonságos és stabil környezet kialakításával. (Galula [1964] 54-55. o.) 


\section{Neoklasszikus szakasz (1982 után)}

Az algériai vereség után nem foglalkozott a francia hadtudomány a felkelésellenes hadviselés témakörével. Csak az afganisztáni francia szerepvállalással indult meg újra a területtel való foglalkozás, az eredményei nem hozzáférhetők. 


\section{FEJEZET}

\section{AZ USA FELKELÉSELLENES ELMÉLETÉNEK FEJLŐDÉSE}

Az alábbiakban bemutatjuk, hogy az amerikai fegyveres erőknek milyen tapasztalataik voltak a felkelésellenes müveletekben és azok milyen hatással voltak az elmélet fejlődésére, illetve az intézményre. Az Egyesült Államokban Nagy-Britanniával és Franciaországgal ellentétben sajátos a helyzet olyan szempontból, hogy Európában a klasszikus szakaszban a konvencionális háborús és az irreguláris konfliktusban zajló szerepvállalások között jelentős feszültségek alakultak ki, amelyek átnyúltak a neoklasszikus szakaszba is. Az amerikai hadsereg esetében ilyen értelemben nem lehet markáns klasszikus szakaszról beszélni, viszont ekkor alakult ki mind a katonai, mind a politikai vezetésben az az elsősorban konvencionális mentalitás, amely nagymértékben háttérbe szorította a felkelésellenes vonulatot.

Bár az Egyesült Államok nem volt gyarmattartó hatalom, mégis gazdag örökségre tekinthet vissza az irreguláris konfliktusokban való szerepvállalás terén. Max Boot ezt vizsgálva három periódust különböztet meg az USA történetében:

1. Gazdasági hatalmi időszak (1700-as évek vége - 1890-es évek): Rövid távú, amerikai gazdasági érdekeltségeket alátámasztó katonai akciók jellemzik, amelyek a disszertáció szempontjából érdektelenek. ${ }^{60} \mathrm{~A}$ szakaszt az Egyesült Államok gazdasági és hatalmi helyzetének megszilárdulása és a kontinensen való aktívabb szerepvállalása zárja.

2. Nagyhatalmi időszak (1898-1941): A spanyol-amerikai háború után az Egyesült Államok számos konfliktusban vett részt, ennek eredményeként több ország került átmenetileg amerikai protektorátus alá (köztük a leghíresebb Kuba). Ezeknek a müveleteknek stratégiai, gazdasági és idealista okai is voltak, és egy jó részük a mai értelemben vett felkelésellenes és stabilizációs műveleti megközelítést igényelt, számos

\footnotetext{
${ }^{60}$ Ebben az időszakban zajlottak az indiánok elleni határháborúk, amelyek irreguláris örökségnek tekinthetők, de mivel hosszú távon részévé váltak az intézményi kultúrának és identitásnak, nem tartoznak a vizsgálat keretébe.
} 
értékes tapasztalatot adva. Ennek a periódusnak a Roosevelt elnök által életbe léptetett új szomszédsági politika jelentette a végét.

3. Szuperhatalmi időszak (1941-től napjainkig): Ebben az időszakban csak átmeneti figyelem irányult a nem állami szereplőkkel szembeni fellépésre, a fö hangsúly a konvencionális államközi müveletekre helyeződött át, a felkelésellenes műveletek kárára. (Boot [2003] xvii-xix. o.)

A vizsgálódást az 1898 utáni időszakkal, vagyis a lakosságközpontú felkelésellenes hadviselés preklasszikus szakaszában kezdjük, amikor az Egyesült Államokban is számos fontos doktrína és elmélet született. Az európai országokkal ellentétben, itt két haderőnem, a hadsereg (ld. Fülöp-szigetek) és a tengerészgyalogság (ld. banánháborúk) is részt vett irreguláris konfliktusokban. Mindkettő szerepe fontos, de míg a tengerészgyalogság szervezeti identitása részévé tette az ilyen konfliktusokban való részvételt, a hadseregben nem gyökerezett meg ez a fajta feladatkör - náluk a két világháború gyakorolt nagy hatást az intézményi identitásra. A relatív méret és fontosság miatt munkánk során a hadsereg szerepére koncentrálunk.

\section{Preklasszikus szakasz: Felkelésellenes konfliktusok a kezdetektől a második világháború végéig (1898-1945)}

A közép-amerikai és a karibi térség 1898 után egyre nagyobb mértékben került az amerikai vezetés figyelmének középpontjába. A jelentős gazdasági érdekeltségek, a nagyhatalmi vetélytársak hiánya és a bizonytalan belső viszonyok ideális terepet jelentettek arra, hogy katonai eszközöket alkalmazzanak az érdekeik érvényesítésére. A banánháborúk néven elhíresült konfliktussorozat fontos tapasztalatszerzési folyamat volt az Egyesült Államok fegyveres erői számára a felkelésellenes müveletek terén. Az indokot a beavatkozásokhoz kezdetben a Monroe-doktrína felélesztése, később pedig Theodor Roosevelt elnök kijelentése adta, mely szerint az Egyesült Államoknak kötelessége beavatkozni ott, ahol a civilizált társadalom veszélybe kerül. (Boot [2003] 129. és 136. o.)

Számos ilyen jellegü beavatkozásra került sor, a következőkben a Fülöp-szigetek (1899-1902), Kuba (1906-1909) és Nicaragua (1926-1933) ügyével foglalkozunk részletesebben. A Fülöp-szigetek esetében hadsereg és a tengerészgyalogság közös fellépése, Kuba esetében a stabilizációs és felkelésellenes müveletek kapcsolata, 
Nicaragua esetében az országban zajló felkelés jellege indokolja a részletesebb elemzést.

Jogi szempontból nézve az amerikai fellépéseket, kicsit visszább kell mennünk a kitüzött időkerethez képest. A polgári lakossággal való bánásmód első szabályozása az amerikai polgárháború idejére esik, ${ }^{61}$ ez szolgált precedensül a későbbi beavatkozásoknál. 1863-ban adták ki az Általános parancs 100 Utasitások az Egyesült Államok hadseregeinek vezetésére a hadszintéren címü kiadványt, amelyben a kor követelményeinek megfelelő módon szabályozták a civilekkel való bánásmód kérdéseit. A dokumentum elöírta, hogy a civilek tulajdonát, vallási és egyéb szokásait tiszteletben kell tartani, és megtiltott minden fegyvertelenekkel szembeni erőszakos fellépést, beleértve a kínzást is. Önmérsékletre szólított fel, de azt is kijelentette, hogy a polgári lakosság és a katonai erök között kölcsönösségi alapú kapcsolat van: ha a lakosság fegyvert ragad és erőszakos lépésekre szánja el magát, a hadseregnek nincs választása a válaszadásra. Az irreguláris fegyveresekkel kapcsolatban az egyenruha döntött a helyzet megítélésénél. Ha egyenruhát viseltek, fegyveres erők tagjaként kellett velük bánni fogságba esésük esetén, ha nem, akkor a kalózok elleni bánásmód vonatkozott rájuk. Az irreguláris fegyvereseket segítő polgári személyekkel szemben számos büntetési lehetőséget sorolt fel. A dokumentum nemzetközi szinten is sikeres volt, számos országnak szolgált mintául a saját szabályozás kidolgozásához. 1914-ig volt érvényben, akkor egy formális doktrína váltotta fel. (Birtle [2006] 32-35. o.)

A fentebb említett konfliktusok közvetlen előzménye, hogy az Egyesült Államok a spanyol-amerikai háború (1898) után aktívabb külpolitikát kezdett folytatni a karibi térségben, és a spanyoloktól megszerzett területek is jelentősebb katonai erőfeszítéseket igényeltek. A háborút lezáró békeegyezménnyel került az Egyesült Államok fennhatósága alá a Fülöp-szigetek is. A másik fontos mozgatórúgó a gazdasági érdekeltségek és az ekkoriban épülő Panama-csatorna védelme volt. Az Egyesült Államok igyekezett stabil politikai helyzetet teremteni a régióban, hogy elkerülje más hatalmak beavatkozását. ${ }^{62}$

A Fülöp-szigeteken zajló konfliktus (1899-1902) jelentette az első jelentősebb kihívást az Egyesült Államok számára. Az amerikai vezetés segítséget nyújtott a

\footnotetext{
${ }^{61}$ Ennek az volt az oka, hogy a konföderáció gerilla erőket alkalmazott, és a parancsnokok egyértelműsítésre tartottak igényt a velük való fellépéssel kapcsolatban.

${ }^{62}$ Ez nem volt alaptalan félelem, ha figyelembe vesszük a kor gyakorlatát a fegyveres adósságbehajtás, vagy az állampolgárok és a gazdasági érdekeltségek védelme terén. Utóbbiak a bizonytalan belpolitikai helyzetü országokban gyakran veszélybe kerülhettek.
} 
szigeteken müködő függetlenségpárti erőknek a spanyolok ellen. Amikor egyértelművé vált, hogy az Egyesült Államok hosszabb távon akar a szigeteken maradni, a szabadságmozgalom szembefordult az amerikai jelenléttel, és egy rövid, konvencionálisnak nevezhető összeütközésre került sor, amiből az amerikai fegyveres erők kerültek ki győztesen. A konfliktus ezután gerilla jellegűvé vált. (Boot [2003] 107111. о.)

A konfliktus sok olyan vonást mutatott, ami a későbbiekben fontos tapasztalatnak bizonyult: szoros civil-katonai együttmüködés, pszeudo-gerilla akció63, hatékony amnesztiaprogram. Másfelől a konfliktusnak sokszor a polgári lakosságot nem kímélő aspektusai is voltak: áttelepítések, kollektív büntetés és felperzselt föld taktika említhető, melyek egy része a kor jogi normái szerint is elfogadhatatlan volt. Hírhedtté vált pl. ${ }^{a}$ tengerészgyalogság egy 1901-es pacifikációs akciója, amelyben parancs szerint nem volt szabad foglyot ejteni. (Boot [2003] 120. o.)

Szerencsére nem ez volt a jellemző, sok jó példa volt a politikai és a katonai szervek együttműködésére. William Howard Taft, az Egyesült Államok későbbi elnöke vezetésével egy széleskörű infrastruktúra-építési és egészségügyi program kezdődött a szigeteken, ami szerves kiegészítése volt a katonai fellépésnek. A békehadtest keretében számos önkéntes érkezett az Egyesült Államokból, hogy ezt a folyamatot segítse (pl. tanárok, orvosok). Taft kezdeményezésére létrejött egy volt békemozgalmi aktivistákat tömörítő politikai párt is, amelynek programja tartalmazta az önállóság jövőbeli megszerzését. (Boot [2003] 114-115. o.) Összességében az amerikai fellépés kiegyensúlyozott volt, és a felkelés elég gyönge ahhoz, hogy az amerikai erök három év alatt meg tudják szilárdítani az irányítást a szigetek nagy része felett.

1927-ben az Egyesült Államok ismételt beavatkozást hajtott végre Nicaraguában. ${ }^{64}$ A beavatkozás mögött regionális meggondolások - elsősorban a Mexikóval kiéleződő viszony - és az amerikai gazdasági érdekeltségek védelme állt.

${ }^{63}$ Frederick Funston dandártábornok a magukat feladó futároktól megtudta a felkelés vezetőjének tartózkodási helyét és azt, hogy erősítést kért egy parancsnokától. A tábornok a helyi erőiből szervezett egy ,felkelő csoportot”, majd elfogta a vezetőt és közeli munkatársait. (Boot [2003] 117119. o.)

${ }^{64}$ Az Egyesült Államoknak már korábban komoly szerepe volt az ország életében: az 1909-ben kitört polgárháborúnak az amerikai tengerészgyalogság vetett véget, majd 1912-ben újabb beavatkozásra került sor a konfliktus kiújulása miatt. Egyik beavatkozás sem járt tartós amerikai megszállással, csupán száz fö körüli amerikai erő maradt az országban a gazdasági érdekeltségek védelmére. Az amerikai politikai és gazdasági befolyás a későbbiekben is jelentős volt. (Boot [2003] 141-142 és 148. o.) Miután Nicaragua visszafizette a tartozásait az Egyesült Államoknak a Hardingadminisztráció a teljes kivonulás mellett döntött. Ezután a belpolitikai ellentétek ismét kiéleződtek, újból polgárháborús helyzet alakult ki. (Boot [2003] 232-233. o.) 
Kétezer tengerészgyalogos érkezett az országba, amivel párhuzamosan közvetítők útján kompromisszumra késztették a szembenálló csoportokat. Az év közepére sikerült békemegállapodást kötni, melynek értelmében a harcoló felek beszolgáltatják a fegyvereket az amerikai tengerészgyalogságnak, és ezt követően új választásokat írnak ki. Az egyetlen parancsnok, aki nem tartotta magát a megállapodáshoz, Augusto Sandino volt, aki sem a megállapodással, sem az amerikaiak jelenlétével nem értett egyet. (Boot [2003] 233-235. o.)

Sandino nem rendelkezett kidolgozott politikai programmal, fö mozgósító üzenete az aktuális politikai helyzettel való elégedetlenség és az Amerika-ellenesség volt, ami nemzetközileg is híressé tette (elsősorban a baloldalon), igaz, a hírnév nem jelentett számára konkrét támogatást. A kezdeti kudarcok után a nicaraguai vadonban sikerült stabil bázist kiépítenie, ahonnan támadhatta az amerikaiakat. (Boot [2003] 235-242. o.) A felkelőknek előnyt jelentett, hogy a hondurasi határ nyitott volt, így szabadon tudtak a két ország között mozogni. Az együttmüködést sem sikerült megtörni a felkelők és a lakosság között. (Boot [2003] 247-248. o.)

$\mathrm{Az}$ 1928-as választásokat Sandino nem tudta befolyásolni, és a belpolitikai viszonyok az amerikai jelenlét mellett stabilizálódtak. Az amerikaiak csökkentették az erőik létszámát, a városok biztosítására (vidéken a helyi erőké volt a vezető szerep) és a polgári biztonsági erők kiképzésére koncentráltak, illetve kis létszámú erőkkel vidéken hajtottak végre támadásokat a felkelők ellen. Ezekben voltak taktikai újítások, mint pl. a légierő felkelésellenes alkalmazása, vagy kis, hosszú távon önállóan és saját forrásokból müködni tudó őrjáratok indítása mélyen a lakatlan területekre, a felkelők menedékhelyére. (Boot [2003] 242-244. o.) Mivel nem tudták leverni a felkelést, az idő elörehaladtával egyre csökkent a hazai politikai támogatás, és végül 1933-ban a kivonulás mellett döntött az amerikai vezetés. Ezt követően a nicaraguai kormány tárgyalt a felkelőkkel, majd koalíciós kormány alakult, ami nem volt hosszú életü: Anastasio Somoza vezetésével a biztonsági erők puccsot hajtottak végre, aminek Sandino is áldozatául esett. (Boot [2003] 250-251. o.)

A stabilizációs és felkelésellenes müveletek kapcsolatára és azok nehézségeire jó példa Kuba 1906-1909 közötti története. ${ }^{65}$ 1905-ben polgárháborús helyzet alakult ki

\footnotetext{
${ }^{65}$ Kuba 1898-1902 között amerikai megszállás alatt volt, akkor az amerikai katonai erők erőfeszítéseket tettek a társadalmi rend megreformálására, és jelentős infrastrukturális fejlesztést és közegészségügyi intézkedéseket hajtottak végre. Az amerikai törvényhozás 1898-ban kizárta a sziget annexióját a Teller kiegészítéssel, 1901-ben a Platt kiegészítés jelentős mértékben korlátozta a függetlenedő sziget szuverenitását a külpolitika terén. (Boot [2003] 132. o.)
} 
egy az ellenzék által elcsaltnak minősített választás nyomán. Az Egyesült Államok diplomáciai küldöttséget menesztett az országba, és amerikai közvetítéssel megállapodás jött létre a harcoló felek között. Ennek keretében 2000 tengerészgyalogos érkezett a szigetre az amerikai vezetésü átmeneti kormány megsegítésére. Charles Magoon lett az ország átmeneti vezetője, aki korábban a Csatorna-övezet kormányzásában vett részt. Minderre azért volt lehetőség, mert mindkét fél elfogadta az Egyesült Államokat, mint pártatlan hatalmat. (Boot [2003] 137-138. o.)

A kubai pacifikációs hadsereg a tengerészgyalogság és a hadsereg egységeiböl jött létre. A rossz közbiztonság kihívást jelentett számukra, de mivel nem akarták a közvéleményt maguk ellen fordítani, a helyi rendészeti erőkön keresztül igyekeztek úrrá lenni rajta. (Birtle [2009] 169-170. o.) Az amerikai vezetés lépéseket tett egy esetleges felkelés megelőzésére, illetve leküzdésére. A Fülöp-szigeteki tapasztalatok alapján átfogó hírszerző hálózatot kezdtek szervezni, és hozzáláttak egy kubai sajátosságokat figyelembe vevő felkelésellenes kézikönyv kidolgozásához. A John W. Furlong által készítet Kubai harctéri szolgálati jegyzetek (Notes on Field Service in Cuba) három fó feladatot határozott meg: az ellenség azonosítását, elszigetelését és elpusztítását. A hírszerzés helyi jellegének fontossága és a felkelés civil apparátusának elpusztítása jelentős súllyal szerepelt benne. A katonai erők fő feladatát a lakosság és a felkelők elválasztásában, valamint a felkelők harci erejének elpusztításában jelölte meg. Utóbbi érdekében erőteljes gyors egységek bevetését javasolta, amelyek üldözik a felkelőket, amíg szükséges. Az amerikai erők a kézikönyv útmutatásaival összhangban kiképzést végeztek és gyakorlatokat is végrehajtottak a csapataik körében. (Birtle [2009] 170-171. o.)

Magoon vezetésével ezzel párhuzamosan zajlott az ország politikai rendszerének reformkísérlete. Itt is súlyt fektettek a közegészségügy és az oktatás reformjára, és jelentős útépítéseket folytattak. A katonai erők azzal támogatták a politikai törekvéseket, hogy létrehoztak egy a vidéki közbiztonság helyreállításáért felelős, kompetens helyiekből álló biztonsági erőt. A kubai vezetéshez való visszatérés érdekében átfogó alkotmányos és jogi reformra került sor, aminek nyomán megtartották a választásokat, amerikai felügyelet mellett. Mikor a helyzetet megfelelőnek ítélték, megkezdték a kivonulást, amely 1909 januárjában fejeződött be. A megszállás a várakozásokkal ellentétben nem hozott alapvető változást, mivel a reformok nem voltak mélyre hatóak. Az amerikai kivonulással automatikusan megindult a visszarendeződés. 
Az amerikai hadsereg a felkelésellenes szerepvállalások ellenére konvencionális háborúra készült. A hadsereg vezetése nyíltan hangot adott abbeli félelmének, hogy a rendészeti feladatok megnehezítik a modern háborúra való felkészülést. Az első világháború megerősítette a vezetést ebben a hitében. A túlkapások kapcsán keletkezett negatív politikai visszhangok szintén a felkelésellenes tevékenység hanyagolásának irányába hatottak. Ez nem jelentette, hogy gátolták volna azokat, akik a konfliktusokban szerzett tapasztalataikat meg akarták osztani. A harctéri jegyzetek müfaja volt ennek a legelterjedtebb formája: taktikai müveleti és logisztikai kihívásokról, illetve földrajzi és egyéb sajátosságokról közöltek cikkeket folyóiratokban és más kiadványokban. A hadsereg felkelésellenes irányú müködése sem szünetelt, csak szükült azáltal, hogy adott egységeket permanensen ilyen jellegű szolgálatra jelöltek ki, ezzel egyszerüsítve a kiképzési és az egyéb vonatkozó feladatok teljesítését. (Birtle [2009] 172-176. o.)

A katonai kormányzás és a gerillaellenes hadviselés része maradt az oktatásnak, doktrínálisan azonban nem rögzítette a tapasztalatokat a hadsereg, így azok - döntően a személyi állomány kicserélődésével - jórészt elvesztek. Ugyanakkor tanulmányozták az európai tapasztalatokat, mivel érezték, hogy a modern technika adta lehetőségeket nem tudták maximálisan kihasználni. A tengerészgyalogság tapasztalatait ebben a periódusban nem tartották tanulmányozásra érdemesnek. (Birtle [2009] 244-246. o.)

Az amerikai hadsereg felkelésellenes megközelítésére jelentős hatással volt a brit minta, úgy a hivatalos brit doktrína, mint a korábban tárgyalt Callwell mü. A hadsereg elismerte, hogy az irreguláris konfliktusokban a konvencionális háború módszerei nem mindig alkalmazhatók, és megfelelő doktrína kidolgozása a sokféleségük miatt igen nehéz. Ugyanakkor hangsúlyozták a modern katonai szervezet és eszközrendszer körülményeknek megfelelő alkalmazását és a másutt bevált módszerek - mint a mobilitás, a helyi segéderők toborzása, a minőségi hírszerzés - fontosságát. A pszichológiai dimenzió kiemelt helyen szerepelt, mivel a civilizálatlan ellenségeknél feltételezték az erő iránti tiszteletet. A politikai dimenzió részletes kifejtése a kulturális és a helyi viszonyok változatos volta miatt elmaradt, de elismerték a fontosságát. (Birtle [2009] 247-250. o.) Az erőszak alkalmazása terén a hadsereg sok kemény lépést támogatott: kollektív büntetés, tulajdon lefoglalása vagy megsemmisítése, túszejtés, szólásszabadság korlátozása, katonai bíróságok alkalmazása a gerillákkal szemben stb. (Birtle [2009] 254. o.)

A hadsereg doktrínájának gyengesége az volt, hogy egyrészt nagyon sok alapelvet és kevés gyakorlati példát tartalmazott, másrészt a felkelésellenes müveletekhez 
szükséges ismeretek nem voltak egységesítve, hanem szétszórtan, a „kis háborúk”, a katonai kormányzás és az expedíciós müveletek témakörénél voltak megtalálhatók. Összességében azonban - az addigi tapasztalatok alapján - koherens egységet alkottak. (Birtle [2009] 260-261. о.)

A regionális ,rendészeti” küldetések jelentős hányada a tengerészgyalogságra hárult, amiért megkapták a „külügyi csapatok” (State Department troops) címet. A tengerészgyalogság doktrínálisan átfogóbb munkát végzett, mint a hadsereg. Ennek eredménye a Kis háborús kézikönyv (Small Wars Manual) megszületése a harmincas évek második felében.

A Kis háborús kézikönyv a korszak doktrínáival összehasonlítva egyedi: a csapatok taktikai problémáitól kezdve a külügyminisztériummal való együttmüködésen át a helyi politikai viszonyok rendezéséig átfogó megközelítést nyújt. Bár taktikai szempontból ma már elavultnak számít, a politikai dimenzióban szinte minden aktuális problémát tárgyal: lakosság lefegyverzése, katonai igazgatás (beleértve a rendészeti kérdéseket), választások megszervezése, kivonulás.

A megszerzett tapasztalatok ebben az időszakban más jellegűek voltak, mint a briteknél és a franciáknál. ${ }^{66}$ Az Egyesült Államok is igyekezett védeni az érdekeltségeit, de ezt nem gyarmati keretek között tette, így a fegyveres erő alkalmazása is más jelleget öltött. Az amerikai tapasztalatok központi eleme a korlátozott idejü szerepvállalás a helyben politikailag hiteles Amerika-barát politikai és biztonsági rendszer kialakítása, valamint választások lebonyolítása céljából. Tény, hogy az itteni felkelések nem rendelkeztek olyan mély politikai-katonai integrációval, mint pl. a maoi mintára épülők, és nem irányult rájuk akkora médiafigyelem. Az expedíciós jelleg - az általában diszfunkcionális helyi intézményrendszer és a kaotikus viszonyok jelentette kihívásokkal - és a fokozott politikai tartalom jó alap lett volna a későbbi doktrínák kidolgozásához. Erre azonban nem került sor a második világháború és az azt követő hangsúlyeltolódások miatt. Így a tengerészgyalogság kis háborús kézikönyve hiába volt az amerikai expedíciós felkelésellenes tapasztalatok legjobb összefoglalása, a vietnami háború idejére feledésbe merült. A küldetések politikai támogatása és gyors végrehajtása szintén fontos tanulság lehetett volna a későbbiekre.

${ }^{66}$ Kivétel a Fülöp-szigetek, amely csak 1947-ben nyerte el a függetlenségét. 
A második világháború idején az Egyesült Államok nem hajtott végre felkelésellenes műveleteket. Éppen ellenkezőleg, az OSS-en keresztül a felkelő erőket támogatta Európában és Délkelet-Ázsiában.

\section{Klasszikus szakasz: Felkelésellenes doktrínák a második világháború végétől 1982-ig}

Az amerikai hadsereg a klasszikus időszakban folyamatos küzdelmet vívott a háborúról kialakított elképzelései és a hidegháború politikai realitásain keresztül rá háruló feladatok végrehajtása között. A szuperhatalmi státus azt is jelentette a hadseregnek és a tengerészgyalogságnak, hogy a második világháború előtti időszakhoz hasonlóan számos irreguláris konfliktusban kellett részt vennie. A Szovjetunió és szövetségesei jelentette fenyegetés és az irreguláris feladatok közötti egyensúly megtalálása azonban majdhogynem lehetetlennek bizonyult.

Sajátos vonása volt a második világháború utáni bő egy évtizednek az ún. „túlgondolkodás”. Ez azt jelentette, hogy a technológiai és egyéb fejlődésre hivatkozva a stratégia kérdéseiben sokan a történelmi példák és szabályok alkalmazhatatlanságát hangoztatták, és forradalmian új elgondolásokat igyekeztek kidolgozni. Ez kezdetben a nukleáris kérdésekre vonatkozott, de idővel kiterjedt a konvencionális és irreguláris konfliktusokkal kapcsolatos kérdésekre is. Ennek eredménye lett a civil szféra jelentős szerepvállalása a katonai stratégiai kérdések vizsgálatánál. Ugyanakkor az is elmondható, hogy ezeknek a változásoknak a jegyében a korábbiakhoz képest felértékelődött a fegyveres erők szerepe az Egyesült Államok külpolitikájában, és jóval szorosabb együttmüködés alakult ki a politikai és a katonai vezetés között. (Birtle [2006] 21. о.)

A hadsereg a második világháború végével intézményileg krízishelyzet elé nézett. Egyfelől a második világháborúban elért sikerei új szintre emelték a teljesítményét, másfelől azonban a nukleáris éra beköszöntével politikailag az irrelevancia fenyegette. A politikai vezetés a légierőben ${ }^{67}$ és a haditengerészetben látta a jövendő konfliktusokhoz szükséges erőprojekciós képességeket. ${ }^{68}$ A hadsereg erre nem tudott hatékony választ adni, de igyekezett a nukleáris alapokra helyezett stratégiák ellen

\footnotetext{
${ }^{67}$ A hadsereg számára a légierő önállóvá válása komoly sokk volt, mivel addig a légierő a hadsereg részét képezte.

${ }^{68}$ A helyzet olyan rossz volt a negyvenes évek végén, hogy sokan a hadsereget a légierőnek alárendelt szerepben látták. (Lewis [2006] 75. o.)
} 
minden eszközzel tiltakozni és akadályozni azokat. Egy masszív összecsapást vizionált a Szovjetunióval, aminek módjáról több kérdés volt, mint válasz. ${ }^{69}$

A hadsereg feladatai a második világháború után ráadásul jelentősen diverzifikálódtak és nagyon jelentős létszámcsökkentésekkel estek egybe. Az amerikai hadsereg Japánban, Németországban és egyéb területeken is nagyon jelentős megszállási feladatokat kapott, fontos szerep hárult rá a dekolonizációban érintett szövetséges országok védelme kapcsán (elsőként Görögországban), továbbá a kirajzolódó hidegháborús törésvonalak mentén is gyorsan meg kellett találnia a helyét, amire a koreai háború adta meg a lehetőséget. Létszáma az 1945-ös 8 millió főről 1950re 700 ezer főre csökkent, jelentős hányada a tengerentúlon megszállási feladatokat látott el, így a konvencionális háborúra való felkészülés gyakorlatilag stagnált. A helyzetet tovább nehezítette, hogy jelentős költségcsökkentéseket is el kellett szenvednie a hadseregnek. (Linn [2009] 152-153. o.) Az így lecsökkent emberi és anyagi források mellett a hadsereg vezetése megpróbálta a saját vízióját artikulálni a jövendő háborújával kapcsolatban, aminek azonban sem a helye, sem az ideje, sem jellege nem volt elöre látható.

A felkelésellenes müveletek szempontjából az amerikai hadsereg egyfajta visszalépést tett ebben az időszakban. A meglévő doktrínális bázist nagymértékben gyengítette, hogy a felkelésellenes müveletekben tapasztalatot szerzett tisztek száma a háború alatt és után csökkent, és az oktatásban is kisebb tér jutott neki. A második világháborúnak azonban voltak olyan aspektusai is, amelyek elöremutatóak voltak: a katonai kormányzás és a hadijog terén fontos tapasztalatokkal gazdagodott a hadsereg. (Birtle [2006] 10-11. o.) Egészében véve azonban a hadseregnek sokszor improvizálnia kellett, amikor tanácsadói feladatokat látott el irreguláris jellegü konfliktusokban, amelyekből elég sok volt: Kínában, Koreában, Indokínában és a Fülöp-szigeteken egyaránt szerephez jutottak az amerikai tanácsadók.

A felkelésellenes műveletek formális doktrínaírásához a negyvenes évek végén kezdtek hozzá. Russell W. Volckmann alezredes - aki a második világháború alatt a Fülöp-szigeteken helyi ellenálló erőket vezetett a japánok ellen - irányította a gerillaellenes doktrína kidolgozását. A háború előtti amerikai tapasztalatok kimaradtak belőle, mivel ekkorra már eltünt az informális tudás, amivel az eseményekben

\footnotetext{
${ }^{69}$ A konvencionális háborús doktrínák is számos jelentős változáson estek át a második világháború után. A konvencionális hadviselés központi doktrínájának tekinthető FM 100-5 Müveletek kézikönyvnek pl. 1945 és 1976 között nyolc változata látott napvilágot. (Birtle [2006] 21. o.)
} 
résztvevők szolgáltathattak volna. Jelentős viszont a külföldi, különösen a

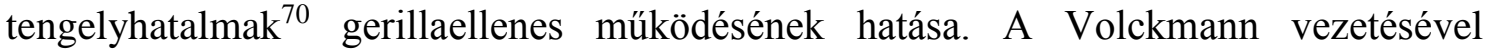
készített FM 31-20 Gerillaerők elleni müveletek doktrína 1951-re készült el, jelentős hatása volt az amerikai fellépésre a Fülöp-szigeteken és Koreában. (Birtle [2006] 131132. o.) A doktrína a konvencionális erőkkel együttmüködő vagy külső támogatással rendelkező gerillacsoportok elleni harcra koncentrált. Kitért a lakosság védelmének szükségességére annak érdekében, hogy a lakosok együttmüködjenek a fegyveres erőkkel. Az erőszak alkalmazásáról szólva elítélte a német túlkapásokat, de erélyes fellépést javasolt, nem vetve el a túszejtés és a kollektív büntetés eszközeit. Taktikai téren sok gondolatot átemelt a német elképzelésekböl, újat keveset hozott. ${ }^{71}$ (Birtle [2006] 135-139. o.) Röviden összegezve: a doktrína igyekezett ötvözni az amerikai és a német harctéri tapasztalatokat.

A gerillacsoportok és felkelések iránti fokozott érdeklődést mutatta, hogy az FM 31-20-at kiadása után nem sokkal követte az FM 31-21 Gerilla hadviselés megszervezése és végrehajtása, valamint az FM 100-5 Müveletek doktrínába egy alfejezet beiktatása 1952-ben, ami a gerilla fenyegetést taglalta. Ennek nyomán 1953ban új doktrína született FM 31-15 besorolással. (Birtle [2006] 143-144. o.)

Fontos állomás volt a doktrínafejlődés szempontjából az FM 27-10 A szárazföldi hadviselés törvénye doktrína, amely az 1949-es genfi egyezményeket magában foglalva illegálissá tette a túszejtést és foglalkozott a lakosság áttelepítésének jogi lehetőségeivel. Ennek nyomán került sor a katonai kormányzási doktrína frissítésére, amely a korábbiakhoz hasonlóan hangsúlyozta az infrastruktúra-helyreállítás, az igazságszolgáltatás, a helyi igazgatás stb. a fontosságát, valamint a helyi szokások tiszteletben tartásának szükségességét. Kiemelte az arányosság és az okok kommunikálásának fontosságát a végrehajtáskor.

A koreai háború csökkentette a gerilla- és felkelésellenes hadviselés iránti érdeklődést, mivel nem játszott olyan fontos szerepet a harcok kimenetében, mint kezdetben gondolták. A háború fordulópontot jelentett az amerikai hadviselési kultúrában: az Egyesült Államok vezetése tudatosan feladta a kezdeményezést, és politikai megoldást keresett a konfliktusra. A gerillaellenes hadviseléssel foglalkozó

\footnotetext{
${ }^{70}$ Ezen belül is Németország tapasztalatai. Az amerikai fegyveres erők több átfogó tanulmányt is készítettek a német hadsereg ilyen irányú tapasztalatairól, számos német tiszt részvételével. A német tapasztalatok ezen a területen évekig meghatározóak voltak. (Birtle [2006] 132-133. o.)

${ }^{71}$ Ilyen volt például a Jagdkommando egységek mintájára létrehozott, önállóan müködni képes kisméretü gerillaelleni csoportok kialakítására tett javaslat. (Birtle [2006] 139. o.)
} 
kutatást a gyalogsági iskolától a különleges erök pszichológiai hadviselési iskolájához tették át, ami a kutatás leállásához vezetett. Az 1958-as doktrínafrissítés alkalmával a gerillaellenes hadviselésre vonatkozó részeket törölték, csak a gerilla hadviselésre fordítottak figyelmet. (Birtle [2006] 147-151. o.)

A koreai háború intézményi szinten is fontos volt. Fordulópontot jelentett, amennyiben ezt követően az európai hadszíntéren megvívandó háború került az amerikai katonai vezetés elképzeléseinek középpontjába. Ekkor még nem volt meg hozzá a politikai támogatás, Eisenhower elnök a költséghatékonyság nevében a légierőt erősítette. Az általa megfogalmazott tömeges megtorlás doktrínában a hadseregnek kevés feladata volt, a megszorítások folytatódtak. Lyman Lemnitzer tábornok ekkor fogalmazta meg a korlátozott konvencionális háború elméletét, amivel szemben a hadsereg vezetése nukleáris fegyverek beemelésével igyekezett növelni a súlyát. ${ }^{72}$ (Linn [2009] 164-169. o.) A politikai vezetés azonban nem volt hajlandó ezzel számolni a következmények miatt.

A hadsereg a csökkenő költségvetési hányada és jelentős emberierő-igénye ellenére komoly technológiai fejlesztéseket és doktrínális változásokat kezdeményezett. Így került sor az ötvenes években a második világháború utáni első jelentős reformra, a pentomikus rendszerü hadosztályok kialakítására. Ez volt az amerikai katonai vezetés szervezeti válasza a nukleáris csatatér jelentette kihívásra. Lényege a nagy mobilitás kisebb létszámú egységekkel, amelyek a helyzettől függően képesek gyorsan szétszóródni és koncentrálódni. A rendszer azonban számos problémával küzdött, köztük azzal, hogy nem léteztek azok a technológiák, amelyekkel megoldhatták volna a logisztikai kihívásokat. ${ }^{73}$ Emellett az is kérdéses, hogy mivel második világháborús tapasztalatokra épült, taktikailag mennyire lett volna alkalmas sikerek elérésére a nukleáris csatatéren. (Linn [2009] 177-179. o.) A rendszert sajátos módon az előtt vezették be, hogy a hatékonyságát vizsgáló gyakorlatok lezárultak volna. A hadsereg így akart magának előnyt szerezni a légierővel folytatott konkurenciaharcban. A pentomikus elképzelés azonban kudarc volt, a hadseregnek rövid időn belül új

\footnotetext{
72 Számos rövid életű és a gyakorlatban felettébb költséges és haszontalan fegyverrendszert állítottak rendszerbe ebben az időszakban. Ilyen volt pl. az M-28 Davy Crockett taktikai nukleáris fegyver.

${ }^{73}$ A hadsereg elképzeléseiben légi szállítású, gyorsan bevethető könnyü hadosztályok szerepeltek, kisebb létszámmal és nagyobb pusztító erővel, mint a hagyományos hadosztályok. A fejlesztési törekvések eredményeként számos fegyverrendszer született meg, mint az M-60 páncélos, az M113 páncélozott csapatszállító és számos gyalogsági fegyver. A logisztikai problémák megoldására azonban az akkori technológiai színvonal nem kínált kivitelezhető megoldást. A hadsereg elképzelései azonban mindenképpen nagyra törőek voltak, a tervek között szerepet egy nukleáris meghajtású, távirányítású teherszállító eszköz, helyből fel- és leszálló képességekkel. (Lewis [2006] 161-162. o.)
} 
szervezeti rendszert kellett bevezetni, ami azzal járt, hogy ideiglenesen romlott a korlátozott konfliktus megvívási képessége. (Lewis [2006] 163-164. o.)

1959-ben a kubai forradalom sikere ismét ráirányította a figyelmet a felkelésellenes és gerillaellenes hadviselés fontosságára. Képzések indultak, és újra előtérbe kerültek a külföldi tapasztalatok. Elsősorban a brit és a francia eredményekre igyekeztek építeni. Ekkor különösen a DGR-irányzat képviselöi hatottak a hadseregre, bár elítélték a franciák polgári lakossággal szembeni erőszakos fellépését Algériában. Az irányzat fő vonzerejét a maoista felkeléselmélettel szembeni kidolgozottsága adta, ami az amerikai doktrínákból hiányzott. (Birtle [2006] 161-163. o.)

Vietnam kapcsán a civil-katonai viszonyok hoztak felszínre új problémákat. John F. Kennedy elnökjelöltsége idején számos ponton hangsúlyozta a felkelésellenes hadviselés fontosságát. Az elnökséget a korlátozott háború elméletének híveként vette át, elutasítva Eisenhower nukleáris erőre építő nézeteit. Újra előtérbe állította a szárazföldi erőket azon az alapon, hogy ők tudják elhárítani a kommunista hátterü felkelések jelentette fenyegetéseket. ${ }^{74}$ Ennek megfelelően született meg a rugalmas válaszadás elmélete, amely a lehetséges katonai fenyegetések széles spektrumára kívánt reagálni. (Lewis [2006] 208-209. o.)

Kennedy szerint a maoista népi háború elmélete új kihívás, amire kiemelt figyelmet kell fordítani. Az ötvenes években nukleáris téren tapasztalt túlgondolkodás a hatvanas években a felkelésekkel kapcsolatban jelent meg. Tanulmányok sora szólt a kihívás újszerüségéről, és Kennedy elnök a hadseregtől is újfajta megközelítést várt a probléma megoldásához. A hadsereg vezetésének az új feladatok nem kedveztek, de pozitívan álltak a politikai kezdeményezésekhez. A végrehajtásban mutatkoztak ellentétek, a katonai vezetés a különleges erökre akarta bízni a felkelésellenes feladatokat, az elnök viszont új megoldásokat, valódi hadsereg-átalakítást akart. ${ }^{75}$ Alapvető stratégiai kérdés húzódott meg e mögött: Kennedy a harmadik világra koncentrált, a katonai vezetés pedig a szovjetek európai fenyegetésében látta a fő veszélyforrást, és a kezdeményezett reformot úgy szerette volna végrehajtani, hogy az

\footnotetext{
${ }^{74}$ Kennedy stratégiájának három fỏ csapásiránya volt: gazdasági fejlesztés, politikai reformok és katonai segítségnyújtás. Birtle szerint változás inkább csak stílusban, nem tartalomban történt. (Birtle [2009] 223-224. o.)

${ }^{75}$ Kennedy nem volt egyedül a nézeteivel, a különleges múveleti közösség támogatta az elnök reformelképzeléseit. A hadsereg sem volt egyedül az új koncepciókkal szembeni ellenállásban, a külügyminisztérium és a Nemzetközi Fejlesztési Ügynökség (Agency for International Development, AID), szintén nem értett egyet a rá vonatkozó változtatásokkal. Emellett a katonai vezetés értékelhette az elnöki fellépést a haderőnem autonóm kérdéseibe való beavatkozásnak. (Birtle [2009] 227-228. o.)
} 
európai érdekek se sérüljenek. (Birtle [2009] 224-225. o.) Másfelöl, létezett egy erőteljes intézményi szintű elfogultság is a felkelésellenes müveletek jelentőségével kapcsolatban. Brian McAllister Linn szerint „A hadseregszerte meglévö intézményi elfogultság azt tartotta, hogy az irreguláris hadviselés nem érhet el döntö eredményeket önmagában, és a gerillák, akiknek nincs konvencionális támogatásuk, nem képesek többre, mint „zavaró jellegü, szórványos rajtaütésekre”.” (Linn [2009] 182. o.) A felkelésellenes hadviselés kérdését egyszerü taktikai problémaként kezelték, amely kifinomultabb felderítéssel és kiképzéssel megoldható. Voltak olyan hangok, amelyek igyekeztek felhívni a figyelmet ennek az álláspontnak a téves voltára, de nem tudtak áthatolni az intézményi elöítéleteken.

Bár elméletben a hadsereg vezetése és az új adminisztráció sok dologban egyetértett, még számos probléma miatt keletkezett feszültség a politikai és a katonai vezetés között. A problémák egy része személyes jellegünek is nevezhető. A McNamara vezette védelmi minisztérium elképzeléseit gyanakvással fogadta a hadsereg vezetése. Személye és hozzáállása nemtetszést váltott ki a haderőnemek vezetői közt, mivel sokszor nem vette figyelembe a tőlük érkező ajánlásokat, útmutatásokat és tanácsokat. A miniszter jelentős reformokat hajtott végre a minisztériumban és a haderőnemeknél is, valamint fontos szerepe volt a Vietnamban követett stratégiai irányvonal kidolgozásában. (Lewis [2006] 210-211. o.) McNamara alatt szüntették meg a pentomikus rendszert, helyette a második világháború alatti rendszerhez hasonló struktúrát alakítottak ki, ${ }^{76}$ és új egységek - pl. légi szállítású hadosztály - felállításába kezdtek. A konvencionális hadviselés került a reformok középpontjába, a nukleáris háborúban való szerepvállalás háttérbe szorult, de megmaradt. (Lewis [2006] 217. o.)

A vietnami háborút megelőző időszakban a felkelésellenes doktrína kidolgozásakor számos forrást - köztük Mao és Che Guevara müveit - használtak fel. Bár a második világháborús német tapasztalatok továbbra is fontosak voltak, a hadsereg nagyobb figyelmet fordított olyan kortárs konfliktusokra, mint a malájföldi és a Fülöpszigeteki felkelés - a Huk lázadás leverésében az amerikai hadsereg tanácsadók küldésével segédkezett, így első kézből származó tapasztalatok is voltak a témában. Az indokínai francia tapasztalatok iránt kicsi volt az érdeklődés, a DRG ekkor lényegében

\footnotetext{
${ }^{76}$ Ez a rendszer a ROAD (Reorganization Objectives Army Division, Átszervezési Célok Hadsereg Hadosztály) elnevezést kapta. A cél az volt, hogy az irányítás rugalmas és célorientált legyen, és a rendszer minél nagyobb mértékben beépítse és kihasználja a technológiai újítások jelentette előnyöket. Ennek eredménye egy nagyobb taktikai hatásfokkal és rugalmassággal bíró, de stratégiailag kevésbé mobil erő létrejötte volt. (Lewis [2006] 217-218. o.)
} 
csak a különleges erőkre volt hatással. Kritikusai szerint a franciák túlzottan konvencionálisak voltak a megközelítésben, nem rendelkeztek elegendő erővel a konfliktus megnyeréséhez és azt is elaprózták, és nem tudtak elegendő politikai támogatást szerezni otthonról.

Az átvett tapasztalok nem voltak olyan univerzális értéküek, mint azt a hadsereg elemzői gondolták - pl. az erőszak alkalmazása a lakosságirányításban a malájföldi és a Fülöp-szigeteki felkelésnél is elkerülte az amerikaiak figyelmét. Bár a Volckmann-féle doktrína - az FM 31-20 Gerillaerők elleni müveletek (1951) - alapján dolgoztak, sok mindent figyelmen kívül hagytak a saját korábbi tapasztalatokból is. (Birtle [2009] 229231. о.)

1961-ben, röviddel Kennedy elnök megválasztása után a hadsereg egy korábban készülő doktrínát vezetett be a felkelésellenes müveletekre: az FM 31-15 Irreguláris erök elleni müveletek ${ }^{77}$ címen. A dokumentum alapvető megállapításai között volt, hogy a gerilla tevékenység a lakossági elégedetlenség egyfajta külsődleges megnyilvánulása, a lakossági támogatás nélkülözhetetlen az ilyen jellegü tevékenység hosszú távú fenntartásához, és megfelelő társadalmi reformok nélkül nem szüntethető meg. Hangsúlyos volt a hírszerzés és a lakosság elválasztása a felkelőktől, ugyanígy a hadsereg képessége a felkelő fegyveres csoportok elpusztítására, hogy a kormányzat hozzáláthasson a károk helyreállításához és a konfliktus rendezéséhez. Fontos újításokat hozott a civil-katonai együttműködési müveletek terén. Átfogó civil-katonai tervezéssel megvalósítható öt elvet ajánlott: 1) egységes parancsnoki lánc, ahol a polgári és katonai programokat minden szinten egy vezető irányítja; 2) az emberi jogok tiszteletben tartása; 3) offenzív fellépés; 4) mobil különítmények létrehozása; 5) katonai, rendőri és politikai müveletek egyidejü végrehajtása.

Fontos kiemelni, hogy az ellenség megsemmisítését hangsúlyozta a dokumentum, nem a terület megszerzését és megtartását. Az FM 31-15 számos javaslattal élt pszichológiai hadviselési, hírszerzési és rendészeti kérdésekben, és figyelmeztetett az elnyomás és a jóindulatú fellépés közötti kényes egyensúly fenntartásának fontosságára. Ez a dokumentum jelentette az alapját a Vietnamban alkalmazott felkelésellenes megközelítésnek, amit a későbbiekben számos doktrína pontosított. A magasabb szinteken nem törekedtek egy általános kormányzati doktrína kidolgozására, ami megnehezítette a hadsereg feladatát. (Birtle [2009] 234-236. o.)

${ }^{77}$ Ez a doktrína váltotta az 1953-ban elfogadott FM 31-15-öt. 
A doktrínális felülvizsgálatok keretében folytatták a meglévő doktrínarendszer fokozatos átdolgozását, melynek a során az FM 100-5 Müveletek kiadványba is bekerült egy felkelésellenes hadviselésről szóló rész. A gerillaellenes müveletek továbbra is jelentős súlyt képviseltek, ezt bizonyítja az FM 31-16 Gerillaellenes müveletek megszületése. A kézikönyv a hírszerzés fontosságát, az erőforrások kontrollját és ellenőrzési eljárásokat javasolt, nagymértékben merítve a brit tapasztalatokból. Az offenzív eljárások terén a Wehrmacht által alkalmazott módszerek közül többet is átvett. Fontos újítás volt, hogy brit mintára több olyan taktika is bekerült a kézikönyvbe, ami nagymértékben támaszkodott tüzérségre az ellenséges gerilla erők megsemmisítésében (aminek a vietnami konfliktusban fontos szerepe lett), ellentétben a tradicionális megközelítéssel. A tüzérséget az ellenséges erők megfélemlítésére és a beszivárgás akadályozására is alkalmasnak találták. Hasonló újító kezdeményezések voltak a páncélos erők alkalmazása terén is. ${ }^{78}$

Az utolsó jelentős újítás a Kennedy érában az FM 31-22 Az amerikai hadsereg felkelésellenes erői volt 1963-ban. Ez a doktrína a korai fázisban lévő felkelések elleni fellépésre készült, ennek megfelelően a szubverzióellenes fellépés, a tanácsadás és a helyi hatóságok támogatása volt a középpontjában. Újdonsága, hogy tisztázta a helyi félkatonai erőkkel kapcsolatos kérdéseket.

Egy évvel később, 1964-ben a hadsereg kiadta az FM 100-20 Harctéri szabályzat: Felkelésellenes müveletek címü doktrínát, ami a hierarchiában a legmagasabb szintü kiadvány volt, és stratégiai szempontok mentén foglalta össze az előző doktrínák főbb vonásait, egyes pontokon mélyítve a bennük foglaltakat.

A fejlődés azonban nem volt egyértelmü abból a szempontból, hogy a gyors egymásutánban készülő doktrínák nem azonos terminológiát alkalmaztak és aránytalanul kerültek be a szélesebb doktrínakörbe (az áttekintési menetrendtől függően). A fegyvernemek részéről is akadt időnként ellenállás a doktrína kiterjesztésével kapcsolatban. (Birtle [2009] 241-251. o.)

1965-ben sor került a felkelésellenes hadviselés konceptuális alapjainak felülvizsgálatára. A doktrína alapjaira vonatkozóan megerősítette a korábban rögzített feladatokat, beleértve a potenciális társadalmi átalakítást is átfogó reformok segítségével. Újdonságot jelentett, hogy a maoi gerillaháború harmadik fázisát már majdnem kizárólag katonai vonatkozásokban vizsgálta. Gyengesége volt a

\footnotetext{
${ }^{78}$ Volckmann munkája nagy hatással volt erre a doktrínára is, terjedelmes részeket emeltek át belőle.
} 
dokumentumnak, hogy a maoi három fázist (stratégiai védelem, stratégiai patthelyzet, stratégiai offenzíva) méretben és nem módszerben tartotta különbözőnek, és ennek megfelelően válasza az eszkalációra hasonló mértékü eszkaláció volt. A háború konvencionális fázisában a felülvizsgálat elegendőnek tartotta a konvencionális támadó és védekező műveleteket a helyzet kezelésére. Annak a lehetőségét egyáltalán nem vizsgálták, hogy az ellenség képes lehet-e magasabb gerilla jellegü egységeket formálni, ami szintén a doktrína gyengesége. (Birtle [2009] 253-256. o.)

Ennek a megközelítésnek volt egy sajátos kettőssége: az Egyesült Államoknak nagyobb eséllyel kellett olyan konfliktusba beavatkozni, ahol a harmadik fázis a jellemző, viszont az amerikai döntéshozók nem lelkesedtek az ötletért, hogy a korábbi szakaszokban nagyszámú harcoló csapatot küldjenek egy külföldi kormány megsegítésére. Vietnamban az amerikai hadseregnek szembesülnie kellett ezzel a problémával. (Birtle [2009] 361. o.)

Dél-Vietnam támogatása ${ }^{79}$ több szempontból is komoly kihívást jelentett. ÉszakVietnam közvetlenül határos volt Kínával, amely jelentős támogatást nyújtott az országnak a franciák elleni harcában. Az amerikai vezetés tartott tőle, hogy Korea mintájára Kína be fog avatkozni, ha az Egyesült Államok szárazföldi hadműveleteket indít az ország ellen. Ebben az időszakban a Szovjetunió is jelentős támogatást kezdett nyújtani Észak-Vietnamnak a háborús erőfeszítéseihez. Másfelől: északi támogatással egy jelentős, déli gyökerekkel rendelkező felkeléssel kellett szembenézni, ${ }^{80}$ amely a határokon kívülről jövő támogatással is számolhatott - a Ho Chi Minh ösvény a szomszédos Kambodzsában és Laoszban is futott. Ezen túl: az északiak hajlandóak voltak konvencionális kötelékekkel támogatni a felkelőket, amikor megfelelőnek érezték ehhez a helyzetet. Délen komoly belpolitikai feszültségek voltak, és a belbiztonságot a felkelés mellett a korrupció, a katolikus-buddhista ellentétek és a biztonsági erők felkészültségének hiányosságai határozták meg. Az Egyesült Államok haderejét és felkelésellenes doktrínáját ezek a tényezők olyan próbának vetették alá, amilyennel korábban nem szembesült. ${ }^{81}$

\footnotetext{
${ }^{79}$ A téma összetett, tárgyalása túlmutat a fejezet keretein. Az alábbiakban a csomópontokra koncentrálunk, és a doktrínafejlődést tartjuk szem előtt.

${ }^{80}$ A felkelésnek a Kommunista Párt Dél-vietnami Központi Irodája (Communist Party’S Central Office for South Vietnam, COSVN) volt a politikai, a Népi Felszabadítási Front (National Liberation Front, NLF) pedig a katonai szervezete. Köznyelvi elnevezésük a vietnami kommunista szóhasználatból átvett Viet Cong. (Moyar [2007] 11-13. o.)

${ }^{81}$ Az Egyesült Államok belpolitikai helyzetét tekintve sem volt könnyü a helyzet: Johnson elnök a belpolitikai törekvései miatt kvázi kompromisszumos alapon vezette a háborút, a stratégiai kérdések sokszor háttérbe szorultak. (Goldstein [2009] 180. o.)
} 
Lewis rámutat, hogy a vietnami háború újdonságot jelentett olyan szempontból, hogy a hadsereg és a tengerészgyalogság feladatai közül tudatosan hiányzott az offenzív fellépés, mivel a légierő volt az offenzív fellépések végrehajtója ${ }^{82}$ (Lewis [2006] 160. o.) A tengerészgyalogság kettős feladatot kapott: egyfelől az ország északi részén a felkeléssel kellett szembeszállnia, másfelől el kellett rettentenie, vagy végső soron szembe kellett szállnia egy esetleges észak-vietnami szárazföldi offenzívával. A tengerészgyalogság korábbi hagyományaira támaszkodva itt is innovatív felkelésellenes programokat indított, melyek közül a legismertebb a Többnemzeti Bevetési Szakasz program (Combined Action Platoon, CAP). Bár a program sikereket mutatott fel, a tengerészgyalogság vezetésében sem volt összhang a megítélésében, a hadsereg pedig nem tartotta példaértékűnek.

Az amerikai és a vietnami fél megállapodott a feladatok felosztásában: a munkamegosztás lényege az volt, hogy az amerikaiak a nagyobb ellenséges erők távoltartásával lehetővé tették a vietnamiaknak a vidéki lakott területek biztosítását. Ez a felosztás nem bizonyult abszolútnak, és a dél-vietnami hadsereg, az ARVN (Army of Republic Viet Nam) is részt vett nagyarányú támadó műveletekben, ahogyan az amerikai hadsereg is a vidéki területek biztosításában. ${ }^{83}$ A stratégia nem volt sikeres, mivel a hadsereg nem volt képes megvalósítani a felőrlő stratégiáját: nem tudta a határt lezárni, így az ellenség pótolni tudta a veszteségeit. (Birtle [2009] 365-366. o.)

Az 1968-as Tet offenzíva politikai jelentősége az volt, hogy szertefoszlatta az amerikai politikai vezetés által a nyilvánosság számára festett optimista képet. (Birtle [2009] 366-367. o.) Az offenzívával a felkelő szervezet jelentős veszteségeket szenvedett, és a korábbiakhoz képest kisebb fenyegetést jelentett. Katonailag az ARVN és az amerikai és szövetséges erők jelentős győzelmet arattak. ${ }^{84}$ A támadás sajtóvisszhangja azonban elég erős volt ahhoz, hogy az amerikai vezetésben aláássa a háborús törekvések folytatása iránti elkötelezettséget, és nagy szerepet játszott abban,

\footnotetext{
${ }^{82}$ A légierő is paradox helyzetben találta magát: az erős politikai felügyelettel korlátozott müveletsorozat messze állt a haderőnem stratégiai bombázási doktrínájától, mivel nem voltak olyan célpontok ÉszakVietnamban, amelyek megfeleltek volna neki. Észak-Vietnam nem volt egy ipari társadalom. a katonai potenciálját a Kínától és a Szovjetuniótól érkező támogatás adta. Bár a konfliktus előrehaladtával a korlátozások változtak, a stratégiai bombázás sosem volt tényleges opció. (Tilford [1991] 283-285. o.)

${ }^{83}$ A pacifikálás terén még egy fontos szervezeti innovációra került sor: a Polgári Műveletek és Forradalmi Fejlesztési Támogatás (Civil Operations and Revoultionary Development Support, CORDS) létrehozására, amely az amerikai katonai parancsnokság alárendeltségében müködött.

${ }^{84}$ Ennek nyomán alakult ki az az érvelés, hogy az Egyesült Államok tulajdonképpen megnyerte a háborút katonailag, és politikailag elvesztette. Az utóbbi években számos olyan publikáció látott napvilágot, amely az amerikai felkelésellenes müveletek sikerét helyezi előtérbe, szembefordulva a hagyományos történeti narratívával. Lásd pl. Lewis Sorely könyveit.
} 
hogy Johnson elnök nem indult újra az elnökségért. Utódja, Nixon a kivonulás mellett kötelezte el magát politikailag, és ez a vietnamizálás politikáját jelentette. A korábbi célkitüzések fokozatosan háttérbe szorultak és a végső, ki nem mondott cél az emelt fővel való kivonulás volt a konfliktusból, ami nagymértékben csökkenő amerikai katonai jelenléttel párosult a folyamat során. Bár sokan a felkelésellenes hadviseléshez kapcsolták a kudarcot, Dél-Vietnam végül 1975-ben egy konvencionális északi offenzívának esett áldozatul.

A vietnami vereség komoly törés volt az amerikai hadsereg huszadik századi történetében. A katonai vezetés szerepét illetően egyfajta kollektív tagadás alakult ki a felelősségre vonatkozóan. Harry Summers ezredes írta le legjobban a kollektív nézeteket, könyve az 1981-es megjelenésétől a domináns narratíva része lett a konfliktust illetően. Summers szerint az Egyesült Államok katonailag győzött, politikailag szenvedett vereséget, mivel a politikai vezetés nem volt képes biztosítani az amerikai közvélemény támogatását, nem akarta mozgósítani a lakosságot, és a növekvő költségek vezettek a háborús támogatás elolvadásához. (Linn [2009] 195. o.) A vereségnek fontos hatása volt a hadsereg struktúrájára, amennyiben kiderült, hogy a sorozott hadsereg nem alkalmas hosszú távú korlátozott védekező háborúk megvívására. A vietnami háború tette politikailag elfogadhatatlanná a sorozott hadsereg fenntartását. ${ }^{85}$

A nagyarányú vietnami müveletek megindulásával az amerikai hadsereg elkezdte frissíteni a doktrínális anyagait. Az egyik fontos felismerés az volt, hogy a maoi hármas fázisban zajló katonai müveletek nem feleltethetők meg egy az egyben egy konvencionális háborúnak, és a politikai szempontokat ebben a fázisban is szem elött kell tartani. Emellett számos egyéb kérdés frissítését is szükségesnek látták. ${ }^{86}$ 1967-re jött ki a hadsereg új felkelésellenes kézikönyvsorozata:

- FM 100-20 Harctéri szolgálati szabályzat: Belső védelem és fejlesztés

- FM 31-23 Stabilizációs mủveletek ${ }^{87}$

- FM 31-16 Gerillaellenes múveletek ${ }^{88}$

\footnotetext{
${ }^{85} \mathrm{Ez}$ a sorozott helyett az önkéntes haderőre való áttérést jelentette. A lépést számos szakmai megfontolás indokolta, a legfontosabb mégis az volt, hogy kevésbé sebezhetővé tette a mindenkori katonai szerepvállalást a lakossági ellenállással szemben, mivel a legfontosabb kapcsolódást szüntette meg a háború és a lakosság között: a kötelező részvételt.

${ }^{86}$ Ilyenek voltak a rendészeti feladatok, hírszerzés, katonai-civil kapcsolatok és számos technológiai jellegü kérdés. (Birtle [2009] 425. o.)

${ }^{87}$ A doktrína érdekessége, hogy ez a politikai reformok végrehajtása terén már nem áll ki a demokratikus reformok mellett. Fontosnak tartotta a felkelő szervezet elleni müveletek végrehajtását, és a nem katonai felkelésellenes müveleteknek nagyobb hangsúlyt adott. (Birtle [2009] 425-429. o.)
} 
Ezen felül még számos területen történt meg a doktrínafrissítés. A tüzerővel kapcsolatban az amerikai hadsereg a hatvanas évek végére teljes fordulatot tett, és elfogadta a nagyarányú tüzerő használatát a felkelésellenes műveletekben. (Birtle [2009] 447. о.)

A következő jelentős fejlesztési hullámra a hetvenes évek elején került sor. Ahogyan korábban is, a folytonosság és az egyértelmüsítés volt a cél. A vietnami háború elhúzódása és az általa okozott politikai problémák miatt új politikai iránymutatás volt kialakulóban, amennyiben az amerikai politikai vezetés részéről a potenciális felkelésellenes müveletekben való közvetlen részvétel politikailag vállalhatatlanná vált. Ennek jegyében fogalmazta meg Nixon elnök a nevével fémjelzett doktrínát, amely a harmadik világban felkeléssel vagy szubverzióval szembenéző államoknak csak támogatást helyezett kilátásba. A Nixon doktrína túlmutatott a Nixonadminisztráción, a későbbi adminisztrációk is alkalmazták. A felkelésellenes müveletekhez kapcsolódó doktrínák érvényben maradtak, de a szerepük elhanyagolható volt, és megújításuk sem volt fontos a katonai vezetés számára. Csak 1986-ban került sor az FM 90-8 Gerillaellenes müveletek kiadására. (Birtle [2009] 482-483. o.) A vietnami háború politikai utóéletéhez tartozik az is, hogy az 1973-as War Powers Act jelentősen csökkentette a végrehajtó hatalom mozgásterét a katonai beavatkozások terén. (Linn [2009] 196. o.)

A hadsereg új doktrínái is a korlátozottabb szerepvállalást kezdték tükrözni. Az 1972-es FM 100-20 már a tanácsadói feladatokat hangsúlyozta a közvetlen katonai szerepvállalás helyett a folyamatban lévő felkelések elleni küzdelemben. Az egyszerüsítési folyamatot az 1974-es FM 100-20 zárta le: ez a felkelésellenes műveletek kérdéskörével foglalkozó egyetlen doktrína az FM 31-16 Gerillaellenes müveletek doktrína mellett. Az 1974-es kiadás már egyértelmüen a Nixon doktrína jegyében íródott. Ennek következtében számos változás történt: a tanácsadói szerepkör elsődleges fontosságot kapott, és a szóhasználatban is változás következett be: a belső védelem és fejlesztés (internal defense and development, IDAD) lett az átfogó elnevezése az irreguláris konfliktusokban végrehajtandó katonai feladatoknak. A hangsúly egyértelműen a felkelések eszkalációjának megakadályozására tevődött át, az alapelvek azonban nagyon hasonlóak maradtak. (Birtle [2009] 452-455. о.)

${ }^{88}$ A pszichológiai és a civil-katonai megfontolásokat jóval hangsúlyosabban kezelte a korábbihoz képest. Ez a kiadás már a vietnami tapasztalatok beépítését is megkezdte, olyan kérdéseket is tárgyalt, mint az alagutak átkutatása. A helyi biztonsági erők megszervezését is kiemelt műveletként kezelte. (Birtle [2009] 430-431. o.) 
A konvencionális paradigma hívei számára kapóra jött 1973-ban a Yom Kippur-i háború, megindulhatott a konvencionális hadviselési doktrína frissítése és a hadseregnek újból a figyelem középpontjába helyezése. Vezéralakja William DePuy tábornok volt, aki 1973-ban az újonnan létrehozott Kiképzési és Doktrína Parancsnokság (Training and Doctrine Command, TRADOC) élére került. Szerinte a doktrína a fegyverzetbeszerzésben, kiképzésben, a tisztikar identitásának és professzionalizmusának alakításában fontos szerepet játszott. Víziója az FM 100-5 Müveletek kézikönyv új kiadásában teljesedett ki. (Linn [2009] 201-202. o.)

A Yom Kippur-i háború olyan tanulságokkal szolgált, amelyek termékenyen hatottak egy új doktrína megírására. ${ }^{89}$ DePuy vezetésével kidolgoztak egy új koncepciót, ami az aktív védelem elnevezést kapta. Eszerint a legfontosabb a következő háború első, felettébb pusztító csatájának megnyerése. A doktrínával több probléma is volt, köztük a legfontosabb az egysíkúsága, mivel a szovjet fenyegetésen túl nem számolt más komoly kihívással, amire az amerikai hadseregnek készülni kellett volna. Ennek a koncepciónak az eredményeként született meg az öt nagy fegyverrendszer - az M1 Abrams, az UH-60 Blackhawk, a Patriot légvédelmi rendszer és az M2 és M3 Bradley -, amely a minőségi fölényt volt hivatva biztosítani a szovjetekkel szemben, de csak a nyolcvanas évek közepén tudott hadrendbe állni. (Linn [2009] 203-205. o.) A doktrína másik érdekessége, hogy a tüzerőt a manőverezés fölé helyezte, háttérbe szorítva az offenzív műveleteket. (Lewis [2006] 294. o.)

\section{Neoklasszikus szakasz: Felkelésellenes doktrínák 1982 után}

A doktrínafejlődés következő lépése a konvencionális irány megerősítésében az 1982-es FM 100-5 Müveletek volt, amit szokás AirLand Battle doktrínának is nevezni a benne megfogalmazott új koncepciók miatt. Ahogyan a neve is mutatja, a hadsereg a korábbi rossz kapcsolatok ellenére szoros együttmüködésre törekedett a légierővel, így kívánva hatékonyan mélységben támadni az elörenyomuló szovjet erőket. A hidegháború végig az AirLand Battle maradt az uralkodó elképzelés (1986-ban volt egy frissítése, ami az alapokat érintetlenül hagyta). (Linn [2009] 209-210. o.)

\footnotetext{
${ }^{89}$ A konfliktus pusztító hatása nagyobb volt a korábbiaknál, részben annak következtében, hogy sok újítás került alkalmazásra, mint pl. vállról indítható föld-levegő rakéták és vezetékes páncélelhárító rakéták. Ezen kívül fontos tanulságokat vontak le a nagyobb veszteségeket okozó logisztikai és mobilizációs sajátosságokból. (Lewis [2006] 294. o.)
} 
A hadseregben voltak, akik ellenezték a hadsereg doktrínájának konvencionális irányba tolását. A kritikusok másik része a hadsereg igényeinek az európai hadszíntérhez való igazítását kifogásolta.

Politikai szinten a konvencionális paradigma következő megerősítése a Weinberger-doktrína meghirdetése volt 1984-ben. Ez a Caspar Weinberger védelmi miniszter nevéhez füződő politikai állásfoglalást - amellyel a hadsereg vezetése is egyetértett - helyezte a középpontba azzal a ki nem mondott céllal, hogy a Vietnamhoz hasonló konfliktusokat elkerüljék. ${ }^{90}$ Hat feltételnek kellett egy konfliktusnak megfelelni ahhoz, hogy az Egyesült Államok beavatkozzon:

1. Létfontosságú nemzeti érdek, vagy egy szövetséges létfontosságú nemzeti érdeke.

2. A győzelem szándékával kell beavatkozni, és ennek érdekében minden forrást elérhetővé kell tenni.

3. Egyértelmü politikai és katonai célokat kell megfogalmazni, egyértelmüvé kell tenni, hogy katonai erővel miként megvalósíthatóak, és annak megfelelő erőket kell bevetni.

4. Folyamatosan vizsgálni kell a kapcsolatot a célok és az erök összetétele között, és változtatni kell, ha szükséges.

5. Biztosítani kell az amerikai közvélemény támogatását.

6. A katonai erők bevetése csak az utolsó lehetőség lehet (Lewis [2006] 301. o.)

A kritériumokkal a korlátozott háborúkat igyekeztek elkerülni. Ez egybeesett egy intenzív technológiai fejlesztési időszakkal, amikor az amerikai haderőnemek elsősorban a légierő - jelentős összegeket fordítottak arra, hogy az emberi tényező helyett a technológia kapja a háború megvívásában a legnagyobb szerepet. (Lewis [2006] 302. o.) Az a hit motiválta őket, hogy a hadsereg elrettentheti a háborús ellenfelet, és hogy az amerikai fegyveres erők képesek arra, hogy a megfelelő mennyiségű tüzerő alkalmazásával az ellenséget passzív áldozattá tegyék egy egyoldalú háborúban. $^{91}$ (Linn [2009] 198-199. o.)

\footnotetext{
${ }^{90}$ Lewis szerint ebben szerepet játszott, hogy a katonai vezetés nem bízott a politikai vezetésben, és a vietnami vereséget nem kis mértékben az akkori politikai vezetésnek tudta be. (Lewis [2006] 300. o.)

${ }^{91}$ Érdekesség, hogy a háborús tervezés a későbbiekben teljes mértékben a katonai kérdésekre korlátozódott, politikai kérdések alig kaptak benne helyet. Ennek látványos példája a Panama ellen végrehajtott támadás, ahol az Egyesült Államok katonai ereje látványos győzelmet aratott, de a konfliktus utáni rendezésre mindössze egy koncepció készült, amit nem fogadtak el. (Phillips [2004] 43. o.)
} 
A Weinberger-doktrína az évtized végére Powell-doktrínává fejlődött, ami a fentiekhez képest hangsúlyosabban kezelte a technológiai aspektusokat, és ki nem mondva az amerikai közvéleményt igyekezett távol tartani az eseményektől. (Lewis [2006] 302. o.)

A hidegháború végével az amerikai fegyveres erőknek komoly identitásbeli kihívással kellett szembenézni: a Szovjetunió és szövetségi rendszere szétesésével nem volt olyan nagyarányú konvencionális konfliktus a láthatáron, ahol az évtizedek alatt felépített doktrína és erőstruktúra használható lett volna. ${ }^{92} \mathrm{Az}$ amerikai hadsereg ismét egy a második világháború végéhez hasonló költség- és létszámcsökkentési fázison volt kénytelen átesni. Ennek jegyében az aktív állomány létszáma 770 ezerről 500 ezer főre csökkent, ${ }^{93}$ a feladatok pedig ismételten sokszínübbé váltak. Nem volt jövőképe a katonai vezetésnek, csak a fenyegetések széles spektruma jelent meg. A hadsereg vezetése emellett nem sok okot láthatott a változtatásra, mivel a hivatalos nyilatkozatok az AirLand Battle sikeréről szóltak. Mindez sokszor irreális politikai elvárásokkal párosult egy dinamikus nemzetközi politikai környezetben, és ez okozott kellemetlen meglepetéseket. A leglátványosabb kudarc a szomáliai beavatkozás volt, aminek kapcsán a civil-katonai viszonyok átmenetileg megromlottak a Clintonadminisztrációban. (Linn [2009] 222-224. o.)

A téma szempontjából a poszthidegháborús éra korai időszakából két jelentősebb elméletet érdemes kiemelni: az ún. katonai ügyek forradalmát (Revolution in Military Affairs, RMA) és a negyedik generációs hadviselést (Fourth Generation Warfare, 4GW). Ezek a fenyegetés jellegét illetően egymással szöges ellentétben lévő irányzatok voltak. Az egyik a konvencionális, technológiaközpontú megközelítést helyezte előtérbe, a másik a konvencionális háborúk elavultságát és egy újfajta konfliktustípus megjelenését hirdette. Az RMA a hadseregben, a 4GW a tengerészgyalogság soraiban lelt támogatókra.

Az 1991-es Irak elleni háború a konvencionális felkészülés sikerét erősítette a hadsereg vezetésében. Sokan az $\mathrm{RMA}^{94}$ megvalósulását látták benne, azt, hogy a technológia fejlődése egy újfajta konvencionális háború megvívását teszi lehetővé. Az

\footnotetext{
${ }^{92}$ Hasonló helyzetben találta magát az amerikai légierő is, amely a szovjetek elleni stratégiai bombázásra és a légi fölény megszerzésére alapozta a saját doktrínáját és felépítését.

${ }^{93}$ Ennek keretében 6. 7. és 9. gyalogos hadosztályt feloszlatták, és döntően a „könnyü” erők kárára hajtották végre a leépítést. (Lewis [2006] 362. o.)

${ }^{94}$ Maga az elmélet érdekes módon nem amerikai gyökerü, hanem a Szovjetunióból ered, az ottani „katonai technológiai forradalom”- elképzelésre vezethető vissza. Az RMA azonban szélesebb megközelítésü, mivel szervezeti és müveleti kérdéseket is magában foglal. (Metz és Kievit [1995] v. o.)
} 
elmélet hívei szerint a technológia segítségével összekapcsolt hatékony összfegyvernemi hadviselést megvalósító konvencionális katonai erők előtt felszáll a „háború köde” és az „információs dominancia” elérésével képessé válnak a harci cselekmények addig nem látott hatékonyságú végrehajtására. Az információs dominancia a csatatér valós idejü áttekintését jelentené minden szinten: a politikai döntéshozóktól a taktikai szintig mindenkinek valós idejű hozzáférése lenne a szükséges információkhoz, amit érzékelők hatalmas hálózata szolgáltatna. Elméletben az ellenséges konvencionális formációk felderítése és a megsemmisítésükhöz szükséges ellencsapások végrehajtása így felgyorsul. Ahogyan Lewis írta: „Gyorsaság, válaszadási képesség, pontosság, rugalmasság, határozottság és csökkentett sebezhetöség volt a cél." (Lewis [2006] 379. o.)

Nagyon népszerü volt az RMA hívei között Arthur K. Cebrowski altengernagy és John Garstka 1998-ban megjelent cikke. A szerzők a napóleoni időszak óta nem látott mértékü technológiai fejlődésre, valamint a közgazdaságtanban, az információs technológiában és az üzleti életben és folyamatokban bekövetkezett változásokra hivatkozva ${ }^{95}$ kinyilvánították a háború természetének megváltozását. Érvelésük középpontjában a hálózatközpontú hadviselés áll, melynek lényege egy földrajzilag nagy területen elhelyezkedő erő nagy teljesítményü támogató információs hálózattal ${ }^{96}$ ellátva. A döntéshozatal felgyorsulását és az alulról felfelé szerveződés hatékonyságát várták a hálózatközpontú megközelítéstől. Erősségének mondták, hogy korlátok között kompenzálni tudja a számbeli, technológiai vagy helyzetbeli hátrányokat. Egy ilyen erő a kommunikáció révén képes az ellenséges erőknek aránytalanul nagy veszteséget okozni, és ezzel lerövidíteni a háborút. (Cebrowski és Garstka [1998]) Az elmélet gyenge pontja, hogy addig nincs vége a háborúnak, amíg az abban részt nem vevő ellenség el nem fogadja a vereséget, mert más módon még képes folytatni a harcot. Ezen túlmenőleg a hálózatközpontú hadviselés nagyon drága, és csak korlátozott konfliktusokban alkalmazható. (Lewis [2006] 380. o.)

Az RMA nemcsak a hadseregben volt népszerü, támogatta a hadsereg polgári vezetése, a légierő és a haditengerészet is. Donald Rumsfeld a Foreign Affairs címü

${ }^{95}$ Üzleti példákon keresztül mutatják be a szerzők, hogy az eszközközpontú megközelítés helyett a hálózatközpontú megközelítést elötérbe helyező cégek mennyire megelőzik a versenytársaikat. Meggyőződésük, hogy az Egyesült Államokat ugyanígy domináns helyzetbe lehet hozni katonai téren.

${ }^{96}$ A szerzök „,beszálló díjnak” egy nagy hatékonyságú információs háló kialakítását tekintik, ami a telekommunikáció és a számítástechnika összekötésére képes, és segítségével egy érzékelő és egy csapásmérő hálózat összekapcsolására nyílik lehetőség. 
folyóiratban 2002-ben megjelent cikkében a képességalapú tervezést helyezte előtérbe, amelynek célja az aszimmetrikus kihívások leküzdése. ${ }^{97}$ Szerinte az Egyesült Államoknak a saját képességeibe kell beruházni, cél az erőprojekciós képesség, a precíziós csapásmérés, az ürkapacitások, a hírszerzés és egyéb (általában fejlett technológiát igénylő) kapacitások kiépítése. ${ }^{98}$ A cikk vége felé gyakorlatilag megismétli az RMA-alapvetéseket: ember nélküli harci rendszerek beszerzése, az észlelés és a csapásmérés közötti idő lerövidítése, a kommunikációs képességek javítása, lopakodó képességü rendszerek alkalmazása, az informatikai sebezhetőség csökkentése stb. (Rumsfeld [2002])

A tengerészgyalogságnál 1989-ben jelent meg a negyedik generációs hadviselés ${ }^{99}$ (röviden $4 \mathrm{GW}$ ) néven ismertté vált irányzat. Képviselői a konfliktus újfajta irányainak megjelenését vetítették előre: az ellenséges társadalom hadszíntérként való alkalmazását - amelynek jellemzője a civil és a katonai vonalak elmosódása, a konfliktus nonlineáris volta -, a logisztikai igények csökkenését, a manőverezés előtérbe kerülését a tüzerő kárára, az ellenség akaratának megtörését a fizikai megsemmisítés helyett, a kommunikációs és pszichológiai dimenzió felértékelődését. Ez természetesen nem jelentette, hogy az RMA és a 4GW között kibékíthetetlen ellentét lett volna. A 4GW képviselői két lehetséges fejlődési irányt vázoltak fel: a technológiai és az ötletközpontú fejlődést. Az első nagy jelentőséget tulajdonított a technológiai fejlődésnek és változtatási képességeinek a jövő csataterén. A másodikon a technológiailag gyengébb potenciális ellenfelek fellépésénél a terrorizmus alkalmazásának változását és egyben a hadviselés egy új lehetőségét értették, amikor a katonai erősségeket kikerülve, közvetlenül támadják az ellenséges társadalmat azért, hogy az akaratát megtörjék. ${ }^{100}$ (Lind et al [1989] 22-26. o.)

\footnotetext{
${ }^{97}$ Rumsfeld ez alatt a terrorizmustól a tömegpusztító fegyverrel ellátott ballisztikus rakétákig gyakorlatilag minden olyan fenyegetést ért, ami nem konvencionális katonai jellegü fenyegetés.

${ }^{98}$ A költségek kérdése felmerül Rumsfeld védelmi miniszter cikkében, és alapvetően a hidegháborús programok leállítását emeli ki, mint fontos forrást. A hatékonyság növelésének jegyében azonban minisztersége elején vizsgálta két további hadosztály feloszlatásának a lehetőségét, hogy az így felszabaduló erőforrásokat más célra használhassák fel, ami ismét a technológiaközpontú gondolkodásnak egy fontos bizonyítéka. (Gordon és Trainor [2007] 9-10. o.)

${ }^{99} \mathrm{Az}$ első generációs hadviselést a merev alakzatok jellemezték a megfelelő tűzerő generálása érdekében, amikor a simacsövü muskéta volt a fő fegyver. A második generációs jellemezője a huzagolt csövü hátultöltős muskéta, az indirekt tűz, a szögesdrót és a lineáris taktikák továbbélése, példa rá az első világháború. A harmadik generációs az első világháború végén alkalmazott német újításokkal kezdődött, amikor már lehetett nem lineáris taktikákat alkalmazni. (Lind et al [1989] 23. o.)

${ }^{100}$ A tengerészgyalogságnál született egy másik elmélet is a kilencvenes évek végén, ami a három háztömbös háború néven lett ismert. Ez Charles Krulak tábornokhoz kapcsolható, aki a kilencvenes évek műveletei alapján a kihívások sokszínűségét emelte ki, azt, hogy a katonák a konvencionális hadviselés mellett - ami maga is nagyot változott (ld. három háztömbös háború) - béketeremtési,
} 
A 4GW a kilencvenes években nem kapott nagyobb figyelmet, 2001. szeptember 11-e után került elötérbe. A 4GW-t Thomas Hammes: A parittya és a kö: Háborúról a XXI. században (The Sling and the Stone: On War in the 21st Century) címü könyve tette széles körben ismertté. Hammes úgy definiálta, hogy „,minden elérhető - politikai gazdasági, szociális és katonai - hálózatot használ, hogy meggyözze az ellenséges politikai döntéshozókat arról, hogy a stratégiai céljaik vagy megvalósithatatlanok, vagy túl sokba kerülnek az elérhető eredményekhez képest. A felkelés fejlettebb formája”. (Hammes [2007] 2. o.) A maoi vidéki központú felkeléstöl eredeztette a hozzá vezető utat, és az iraki háborúig számos esettanulmányon keresztül mutatta be a $4 \mathrm{GW}$ lényegét.

Az irányzat képviselői azonban nem voltak egységesek, így gyorsan megjelent az ötödik generációs hadviselés (fifth generation warfare, 5GW) elmélete. 2007-ben Thomas Hammes is saját 5GW-s elképzelésekkel jelentkezett. A stratégiai környezetben bekövetkezett alapvető változások miatt tartotta szükségesnek az $5 \mathrm{GW}$ bevezetését. Ezeket az alábbi módon csoportosította:

- Stratégiai változások: a korábbi gerilla hadviselésre építő, kommunikációval megtámogatott stratégiákat a stratégiai kommunikációra épülő, gerilla akciókkal támogatott stratégia váltotta fel.

- Szervezeti változások: a hierarchikus irányból a hálózatközpontú szerveződés felé mozdult el a nem állami fegyveres csoportok szervezési modellje, ami eltérő csoportok, akár bünözői csoportok együttmüködését is jelenti.

- Szereplőbeli változások: egy országon belül is számos fegyveres csoport harcolhat eltérő célokért. Négy ilyen típust különböztet meg: reakciós, opportunista, ideológiai és hibrid.

Hammes szerint a technológiai fejlődés lesz a jövő fenyegetésének fő mozgatója, mivel eddig nem látott képességekkel (pl.: biológiai hadviselési képességek) fogja felruházni a nem állami szereplöket, eddig nem látott költséghatékonysággal. Az 5GW jellemzője az lesz, hogy egyre kisebb csoportok kezébe fog kerülni egyre nagyobb hatalom, és a politikai lojalitások egyre inkább különböző politikai okok irányába fognak eltolódni a fennálló entitások (államok) irányából. (Hammes [2007] 14-23. o.)

békefenntartási, humanitárius segítségnyújtási feladatokat teljesítettek térben szoros egymás mellé rendelödésben. A másik fontos megállapítása a legalacsonyabb taktikai szint fontossá válása volt, aminek leírására megalkotta a stratégiai tizedes fogalmát. (Krulak [1999]) 
Az amerikai hadsereg a kilencvenes években bevezette a nem háborús műveletek (Operations other than War, OOTW), majd a nem háborús katonai müveletek (Military Operations other than War, MOOTW) fogalmát. Előbbit az 1993-as FM 100-5 Müveletek részletezte. Ide sorolták a felkelések és a felkelésellenes műveletek támogatása mellett többek között a civilek evakuálását nem katonai müveletekben, a fegyverzetellenőrzést, a civil hatóságok támogatását, a humanitárius segítségnyújtást és katasztrófaelhárítást, a biztonsági támogatást, a békefenntartást és a drogellenes mủveleteket. (FM 100-5 [1993] 13-7 - 13-8. o.) Az MOOTW meghatározása az 1995 ös JP 3-07 Nem háborús katonai mủveletek összhaderőnemi doktrínában történt meg. E szerint a nem háborús katonai müveletek célja a háborútól való elrettentés, a konfliktusmegoldás, a polgári hatóságok támogatása és a béke elősegítése, amikhez katonai és nem katonai eszközök is felhasználhatók békében, konfliktusos időszakokban és nyílt háborús helyzetekben egyaránt. (JP 3-07 [1995] I-1. o.) Az MOOTW tehát átvette az OOTW számos feladatát, és az Irak elleni offenzíva idején is érvényben volt. 


\section{FEJEZET \\ A FELKELÉSEK MODERN PROBLÉMÁI}

\section{A felkelés fogalmának változása a klasszikus értelmezéshez képest}

A jelenleg nyugati részvétellel zajló felkelésellenes műveletekben a dzsihádi mozgalomnak nevezett, széles ideológiai hátterü csoportok a meghatározó tényezők. A változásokat ezért a nyugati szakirodalom mellett a mozgalom két tagja - Abu Bákr Nádzsi és Abdelaziz al-Mukrin - által írt elméleti munkák segítségével mutatjuk be az alábbiakban. A saját területükön mindketten jelentős hírnévre tettek szert: Mukrin a szaúdi dzsihádi csoport vezetője volt, sok konfliktusban vett részt. Halála után hívei a cikkeiböl állították össze a kötetet, amely felöleli munkásságát. (Cigar [2008] 6-7. és 10-11. o.) Nádzsi személye lényegében ismeretlen, inkább csak találgatások vannak róla, a munkája viszont - amelynek témája a dzsihádi csoportok irányító szerepének kiterjesztése - jelentős figyelmet keltett.

Az iraki és az afganisztáni konfliktusnak vannak olyan jellemzői, amelyek meglehetősen egyedivé teszik őket más felkelésekhez képest. Ilyen az államhatalom hiánya, a lakosság nagyarányú felfegyverzettsége és a fegyverek könnyü beszerezhetősége, jelentős etnikai-felekezeti feszültségek megléte és olyan szociálistársadalmi hálózatok létezése, amelyek mentén a felkelések szervezése könnyen megindulhatott. Fontos azonban mindehhez azt is hozzátenni, hogy a két ország politikai, földrajzi, társadalmi és egyéb jellemzői eltérő jellegü felkelést produkáltak. Irakban egy döntően városi jellegü, minimális külső támogatást élvező, jelentős etnikaifelekezeti dimenzióval rendelkező, számos vetélkedő csoport részvételével zajló konfliktus alakult ki. Afganisztánban egy vidéki jellegü, jelentékeny külső támogatással rendelkező, etnikai és törzsi dimenzióval rendelkező, kevésbé jelentős számú csoport részvételével zajló konfliktus jött létre. Az alábbi példák segítségével - amelyek közül az irakiak a hangsúlyosabbak - próbálunk rávilágítani arra, hogy a klasszikus értelmezéshez képest miben más a modern felkelés. 


\section{A dzsihádi csoportok jellemzői}

A dzsihádi mozgalom erősen függ a karizmatikus vezetőtől, az ideológia és az egyéb tényezők e mellett csak kisebb szerepet játszanak. Ezt mutatja, hogy a „mártírrá” vált vezetőket nagy tisztelet övezi, a legkarizmatikusabb vezetők csoportjai a legtöbb halálos áldozatot követelő akciók végrehajtói, akik hajlandóak szinte bármire. (Gerges [2009] 34-36. o.) A formális döntéshozatali rendszer - amely általában bizottságokra épül (shura rendszer) - ennek megfelelően nem sokat számít, mert jó eséllyel az történik, amit a karizmatikus vezető akar. A csoportok nem kreálnak tartós belső intézményi struktúrákat, amelyek képesek lennének a karizmatikus vezető befolyását ellensúlyozni és korrigálni, vagy a kiesését kompenzálni. Ez szűk társadalmi támogatottsággal párosul és egy még szükebb szervezett támogatást jelent a mozgalom számára. Így a földalatti jellegen és mentalitáson nem tudnak túllépni, nem tudnak pozitív stratégiát megfogalmazni. (Gerges [2009] 41-42. o.)

Emellett vannak sajátosan a vallási radikálisokra jellemző gyengeségek is, mint pl. a gyenge vallásjogi háttér. A csoportok kötelékében jelen lévő kisszámú vallástudós általában nem képes felvenni a versenyt az adott országban hivatalosan elfogadott vallásjogi tekintélyekkel. Ezáltal az erőszak alkalmazásának és a csoport létének az egyetlen és legföbb legitimációs forrása nem elhanyagolható mértékben gyengül.

Nincsenek továbbá sikeres példák, nincsenek olyan megvalósult állami kísérletek, amelyek hatékony ösztönzők lehetnének a tömegek számára. Ami Afganisztánban és Csecsenföldön megvalósult, nem bizonyult követendőnek, sokkal inkább elrettentő hatása volt.

Beszélhetünk továbbá egy stratégia - vallási doktrína szakadékról is. Az iszlám szalafi irányzatának „doktríner” megközelítése komoly hatást gyakorolt a dzsihádi mozgalomra az 1990-es évek eleje óta. A szalafi megközelítés felemelkedése csökkentette a politikai tartalmat a jelenlegi dzsihádi ideológiában, gyengítve ezzel az alkuképességét. (Lia [2010] 129-130. o.)

A kortárs dzsihádi felkelök egy alapvető problémával küzdenek, ez pedig a politikai program hiánya. Brynjar Lia szerint: „Ennek valószínüleg az az oka, hogy a purista dzsihádik a konkrét földi célokra való fókuszálást úgy tekintik, mint az Isten iránti engedetlenség egy formáját, a földi világgal való profán foglalatoskodást és a földi utáni életre vágyakozás hiányát. Még a stratégiai gondolkodásban mélyen elmerült 
dzsihádi irók és politikai kommentátorok is szükségét érzik, hogy emlékeztessék a közönségüket arra, hogy: „, a stratégia nyugati szó” (...)”. (Lia [2010] 101. o.)

Fawaz Gerges dzsihádi aktivistákkal készített interjúk alapján megerősíti a fenti kijelentést. Tanúságuk szerint a dzsihádi mozgalom képviselői is elismerik a politikai gyengeségüket és azt, hogy túlzottan a hatalom megragadásával vannak elfoglalva, és kormányzási, illetve gazdasági kérdésekre nem fordítanak kellő figyelmet. (Gerges [2009] 99. о.)

A dzsihádi csoportok egyfajta elitcsoportként, felülről bevezetett reformokkal kívánják a céljaikat elérni, legyenek azok bármilyen nehezen körülírhatóak. Ennek megfelelően nincs olyan támadható legális vagy féllegális támogatói csoport, amely kifejezetten erőszakmentes, vagy minimális erőszakot alkalmazó szubverzív feladatokat látna el. Az erőszakmentes megközelítés hiánya a politikai rendszer teljes elutasításából fakadóan érthető: a csoportok a saját meghirdetett céljaiknak mondanának ellent, ha kompromisszumot kötnének. Ez azonban azt is jelenti, hogy így egy általánosságban átpolitizált társadalomban a kommunikáció segítségével elérhető mozgósító erő jóval korlátozottabb.

\section{Dzsihádi felkelő stratégia: Mukrin és Nádzsi}

A két szerző munkáját érdemes egymás mellé tenni, mert eltérő szemszögből vizsgálják a fennálló konfliktus jellemzőit. Mukrin egy alapvetően katonai szempontokat szem előtt tartó munkát írt, Nádzsi azt vizsgálja, hogy miként tudja a dzsihádi mozgalom a tevékenysége révén keletkezett káoszt kiaknázni és a maga hasznára fordítani. (Naji [2006] 23. o.)

Mukrin a stratégiai célok közé sorolja az iszlám rendszer/állam létrehozását, az elnyomott muszlimok felszabadítását és egy iszlám alapokon nyugvó társadalom létrejöttét. A megvalósítás módja a fegyveres harc, amely a következő részcélok teljesítésével jut el az ütőképes hadsereg létrehozásáig:

1. A háború elnyújtása annak érdekében, hogy ellenállást váltson ki. (Nem kell támadni olyan célpontokat, amelyeknél az ellencsapás komoly károkat okozna.)

2. Megfelelö harci tapasztalatok szerzése (Fokozatosan, gyakorlás és kemény munka révén, célja a morál növelése.) 
3. Sikeres fázisváltás elérése. (Látványos erők létrehozása az ellenség túlsúlyának megszüntetésére, annak ellenlépései ellenére. A sikerek hatására a mozgalom erősödni fog a lakosságból érkező önkéntesek révén.)

4. Katonai erő kiépítése, amely a hadsereg magját fogja adni. (A cél tehát egy hadsereg létrehozása, amely képes lesz a konvencionális erőkkel szembeszállni.) (Cigar [2008] 92-94. о.)

A gerilla háborút klasszikus maoista módon osztja három fázisra:

- Első fázis: felőrlés (stratégiai defenzíva). A mozgalom sikeres propagandával biztosítja a lakosság támogatását, jelentős szervezeti expanzión megy keresztül, és így belép a gerilla hadviselés fázisába. A kormány hatalma meggyengül, az ország területének egy része a dzsihádi csoport(ok) kezébe kerül.

- Második fázis: relatív stratégiai egyensúly (az ezer vágás politikája). Az ellenséges kormány politikai és katonai vezetése között kiéleződik az ellentét a kudarcok miatt, sor kerülhet katonai puccsra. A dzsihádi csoportok sikere miatt növekedni fog az ellenség felé irányuló külföldi támogatás, akár külföldi beavatkozásra is sor kerülhet.

- Harmadik fázis: katonai döntés (végső támadás). Nő az ellenséges dezertőrök és átállók aránya. A kapcsolatokat intenzifikálni kell a távoli dzsihádi csoportokkal. A kormányzat kiszorul a vidékről, a városokra koncentrálja az erejét, offenzív lépéseik légi és tüzérségi támadásokra korlátozódnak. A hadsereg vezetése végül tárgyalni fog a dzsihádi csoporttal. (Cigar [2008] 94-101. o.)

Mukrin tehát a konvencionális összecsapásig vizionálja a fegyveres harc folytatását, és arra biztatja a híveit, hogy a konvencionális és nem konvencionális harci eljárásokat a lehető legjobban igyekezzenek kombinálni. Számos javaslatot tesz arra, hogy a harci szervezetet miként kell felépíteni a konvencionális szakaszban, nyugati mintára.

Nádzsi munkája arról szól, hogy miként lehet a dzsihádi mozgalom tevékenysége révén keletkezett káoszt a mozgalom javára kiaknázni. A szituációt olyan történelmi jelenségnek nyilvánítja, amely birodalmak bukása után keletkezik. Döntően a mozgalom kezére került területek igazgatásával foglalkozik, és gyakorlatilag egy a helyzet stabilizálódásával fokozatosan bővülő igazgatási rendszer kiépítését írja le.

Nádzsi céljai:

- Az Egyesült Államok tekintélyének aláásása és támogatói kör kiépítése 
- az Egyesült Államok gyengeségének előtérbe állításával a kommunikációban, és

- az Egyesült Államok közvetlen beavatkozásra kényszerítésével az arab világban.

- A mozgalom veszteségeinek kompenzálása:

- az ellenséggel szemben végrehajtott müveletek sikerének ösztönzésével, és

- az amerikai beavatkozás miatt felgyült haragnak az arab rezsimek felé irányításával.

- Az Egyesült Államok beavatkozásra kényszerítésével ténylegesen fel kell fedni a képességei és a retorikája közötti különbséget, megerősítve ezzel a korábbi üzenetet. (Naji [2006] 21-23. o.)

Stratégiájának sajátossága, hogy internacionalista dzsihádi szellemben nem egy országra terjedő stratégiát fogalmaz meg, hanem a teljes iszlám világban javasolja fegyveres akciók létrehozását, két-három kiválasztott régióra koncentrálva. A kiválasztott régiókon kívüli akciók a szolidaritás jelei lesznek, és a hatóságok figyelemének megosztását szolgálják. A folyamat lényege, hogy a biztonsági erőket ki kell szorítani a peremterületekröl, ahol azután a dzsihádi csoportok megvetik a lábukat, és elkezdődhet az elmélet átültetése a gyakorlatba. (Naji [2006] 37-39. o.)

Nádzsi egy sajátos fogalmat vezet be, a „barbárság igazgatása”-t. Véleménye szerint a birodalmak bukását sajátos szociológiai jelenségek kísérik, amiket lehet siettetni. Történelmi példák segítségével azt kívánja illusztrálni, hogy az összeomlás után, amikor nem volt más hatalom, ami betölthette volna a keletkezett ürt, egyes területek a „barbárság igazgatása” alá kerültek. A fogalmat nem definiálja pontosan, hanem dinamikus fogalomként kezeli, a következőképpen: „(...) a barbárság igazgatását röviden a civilizálatlan káosz igazgatásaként definiáljuk!” (Naji [2006] 23. o.) Ennek megfelelően a definíció a mindenkori céloknak és az adminisztráció természetének megfelelően változik. Kezdetben az élelmiszer- és egészségügyi ellátás, a biztonság fenntartása, az igazságszolgáltatás, a határok biztosítása, a behatolni készülők elrettentése, védelmi erődítések felállítása a cél. Ez a szint később kiszélesedhet olyan szolgáltatások biztosítására, mint az oktatás és a biztonság fenntartása, a határok biztosítása pedig kiterjed a barbár területre. (Naji [2006] 23. o.)

A barbárság igazgatását egy három szintű rendszerbe helyezi. Az első szakasz a „zaklatás és kifárasztás szakasza”, ezt követi a „barbárság adminisztrációjának 
szakasza”, majd végül következik az „alapítás ereje - az állam létrehozása” szakasz. (Naji [2006] 33. o.)

Nádzsi a müvének jelentős részében arra törekszik, hogy a főként nyugati mintákat követő igazgatásszervezés hasznosságát bemutassa, illetve összeegyeztesse a fegyveres harc keltette igényekkel. Ennek alátámasztására megfogalmaz médiastratégiát is, politikai célokat azonban nem.

\section{A változás egyéb vetületei}

\section{Konkuráló csoportok}

A talán legszembetünőbb különbség napjainkban a klasszikus felkelésekhez képest, hogy a felkelés most nagyszámú független felkelő csoport tevékenységéből áll össze. A klasszikus centralizált, párt vagy politikai csoport vezetésével végrehajtott felkelés ma nem jellemző. A felkelő csoportokat egyesítő elem általában valamilyen negatív cél (pl.: az idegen katonai jelenlét elleni küzdelem). Ilyen egyesítő tényezőnek a megléte sem zárja ki azonban az egymással való fegyveres vetélkedést erőforrásokért vagy területért.

\section{Szervezeti háttér}

A modern felkelő csoportok praktikus okoknál fogva nem tartanak fenn gerilla jellegü erőket, hacsak a földrajzi környezet nem kifejezetten kedvez ilyen csoportok müködésének. Az élcsapat jelleggel és a politikai kompromisszummentességgel együtt ez egy aránylag kis szervezetet jelent annak ellenére, hogy jellemzően városokban jönnek létre, és a felkelések is városi jellegüek.

A szervezet a célja azonban nem tér el sokban a klasszikus felkelői céloktól, ha azt vesszük, hogy erőszak alkalmazásával kívánják a fennálló államhatalmat aláaknázni adott területen.

\section{A gazdasági modell változása}

A klasszikus időszakban a lakosság volt a gerilla csoportok elsődleges forrása az élelmiszert, a gyógyszert, a ruházatot, a szállást stb. illetően, ezért elsőrendű feladat volt 
a fegyveres csoportok elszigetelése a lakosságtól. Fentebb már szóltunk róla, hogy ez a helyzet gyökeresen megváltozott. A dzsihádi csoport nem tud ellenőrzést gyakorolni a lakosság felett, főként a szervezeti hiányosságai miatt. Emellett azonban sokkal inkább arról van szó, hogy az elődeivel ellentétben nem is szorul rá a lakosság segítségére.

A kisebb méretü szervezet elvileg kisebb igényeket támaszt, de az igények is alaposan megváltoztak. Ezek kielégítésére az elmúlt évtizedekben új finanszírozási lehetőségek adódtak, úgymint: szervezett bünözés, határokon átívelő adományok civil szervezeteken keresztül, drogtermelés, csempészet, gazdag támogatók megnyerése stb. David Kilcullen rámutat arra, hogy a finanszírozási modell megfordult Irakban és más konfliktusokban is: nem egy esetben megtörtént, hogy a felkelök felbérelték a lakosságot vagy annak egyes tagjait különböző feladatok elvégzésére (Kilcullen [2006]), vagyis az említett forrásokból rendelkezésükre álló pénzekkel képesek mozgósítani a lakosság egy részét.

\section{A város mint hadszíntér előtérbe kerülése}

A városok szerepe az utóbbi évtizedekben felértékelődött a felkelők szempontjából. Míg Marighella idején a városi fellépés csak a vidéki felkelés velejárója volt abból a célból, hogy elterelje a figyelmet a vidékről, a mai csoportok adottságaiknál fogva a városi terepet részesítik előnyben.

Ennek jó példája, amit Mukrin ír a városokban végrehajtandó müveletekkel kapcsolatban. Szerinte a „városokon belüli támadásokat katonai-diplomáciai feladatként kell felfogni.(...) Politikai jelentésük van, ami kapcsolódik az ideológiai harchoz. Vagyis olyan eszközként lehet értelmezni, aminek segitségével nagyobb célközönséghez lehet üzenetet küldeni. Ennek megfelelöen a célpontokat nagyon nagy óvatossággal kell megválogatni (...). ”(Cigar [2008] 127. o.)

A városi célpontokat három fő csoportra osztja:

- Ideológiai jellegü célok: vallási célpontok támadása, amit Mukrin a kezdeti fázisban csak kivételes esetben javasol

- Gazdasági célok: a biztonságérzet gyengítése és a gazdaság megzavarása a cél. A külföldi cégek fontos célpontok.

- Emberi célpontok: elsősorban zsidók és keresztények, és nemcsak a szűken vett müveleti területen belül. Mint írja: „A sejteknek mindent meg kell tenni, hogy a hitetlenek országait hadszintérré változtassák, és hogy a hitetlen és 
együttmüködö országok az ezzel való foglalkozásra összpontositsanak.” (Cigar [2008] 129. o.) Kiemelt célpontot jelentenek a muszlim országokban hivatalos pozícióban lévő keresztények. Ezen a téren Mukrin egy komplex célprioritási sorrendet is megfogalmaz, a regionális különlegességeket is figyelembe véve. Ennek előnyét abban látja, hogy az ideológiai harc jellegét egyértelművé teszi, elrettentő hatása van az ellenségre, morálnövelö a saját közösségre, bomlasztja a rezsim presztízsét, politikai akadályokat emel az arab és a nyugati országok között, és retorzió a sérelmekért.

Mukrin a városi müveletekkel kapcsolatban az elönyöket és a hátrányokat egyaránt sorra veszi. Az előnyök közé sorolja a saját erök moráljának növelését, a csoport hitelességének megalapozását a közvéleményben, az ellenség megfélemlítését, fontos célpontok elpusztítását, gyakorlat szerzését, a lakosság felkészítését a jövendő összecsapásokra, a dzsihádi csoportok népszerüségének növekedését, politikai változásokat a rezsim részéről, a rezsim vezetőinek elbizonytalanítását, belpolitikai instabilitás keltését és a hibákból való tanulás lehetőségét.

Hátránynak tekinti a potenciális anyagi és emberi veszteségeket (utóbbit föleg a vezetői szinten), kudarcok esetén a morál hanyatlását; félresikerült müveletek civilek elleni támadásként való beállítását az ellenség által, ami növelheti az ellenség magabiztosságát; azt, hogy a csoport tagjainak fogságba kerülésével fontos információk kerülhetnek az ellenséges erők birtokába, és hogy a lakosság bizalma többszöri kudarc esetén meginoghat a dzsihádi csoportban. (Cigar [2008] 127-132. o.)

\section{Lakossági háttér}

Napjaink dzsihádi csoportjainak kapcsolata a lakossággal általában nem intenzív, mivel kevés a megértés bennük az erőszak alkalmazása iránt, ami részint visszavezethető a politikai üzenet hiányára. A fegyveres harc pedig, amit a hatalom megragadása egyetlen elfogadható módjának tartanak, a lakosság jelentős hányadát elidegeníti.

Az elmélettel foglalkozó szerzőknek fontos a lakossági támogatás megszerzése és megtartása. Mukrin hangsúlyozza, hogy a dzsihádi csoportoknak is tenniük kell a megfelelő körülmények kialakulásáért, és ezt elsősorban látványos merényletek végrehajtásával tartja megvalósíthatónak. Fontos ehhez a lakossági támogatás is, de „, figyelmet kell forditani az egyszerü emberek helyzetére, a jogaikat és szükségleteiket 
feladatként kell kezelni, és szükséges velük élni és megosztani örömüket és bánatukat. (...) A mudzsahedineknek szem elött kell tartaniuk, hogy az emberek többsége a mindennapi élettel van elfoglalva, és a napi betevő falat megszerzéséért folytatnak küzdelmet. Ennek fényében a mudzsahedinek nem számíthatnak sok támogatásra (...)”.(Cigar [2008] 104. o.) Mukrin szerint meg kell győzni a lakosságot a dzsihádi célok helyességéről. A meggyőzendőket két csoportra osztja:

- Passzívak, akik nem lépnek be közvetlenül a dzsihádi mozgalomba, de hajlandóak támogatni pénzzel, anyagi javakkal, információval, logisztikai segítséggel, és sikerek elérése után meggyőzhetőek a csatlakozásról. Az elnyomott és kiszolgáltatott emberek általában aktívan is támogatják a dzsihádi célokat.

- Aktívak, akik önként járulnak hozzá a fegyveres harchoz morális és anyagi értelemben (információk, menedék, ellátás stb.), alávetik magukat a dzsihádi vezetés akaratának, és hajlandóak kockázatot vállalni. (Cigar [2008] 105. o.)

A fentiekből nyilvánvaló, hogy elméleti síkon felismerték a lakossági támogatás hiányából fakadó veszélyt, de nem tudnak olyan módszert, ami a támogatás megszerzését és megtartását az erőszakos eszközök alkalmazásán túl biztosítani tudná.

\section{Az információs környezet megváltozása}

Az információs forradalom a technológiai oldalon megkönnyítette a propagandaanyagok készítését és terjesztését. Míg korábban a magnókazetták és a rossz minőségü videokazetták jelentették a technológiai csúcsszínvonalat, az internet, az olcsó digitális videó és fotó elterjedése és az arab nyelvű műholdas televíziózás új távlatokat nyitott meg a csoportok előtt. Ez nemcsak a hatékonyabb üzenetküldést tette lehetővé, hanem a konfliktusos terület határain kívülről érkező támogatás hatékonyabb becsatornázását is az önkéntesekre, a pénzre és egyéb szempontokra vonatkozóan is. 


\section{HARMADIK SZEREPLŐS FELKELÉSELLENES HADVISELÉS}

\section{Mi a harmadik szereplős felkelésellenes hadviselés?}

A klasszikus felkelésekben két oldalt különböztethettünk meg általánosságban: a felkelőt és a felkelésellenes erőt/kormányzatot. Napjaink felkelésellenes konfliktusaira azonban ez a modell nem alkalmazható. Mind az afganisztáni, ${ }^{101}$ mind az iraki ${ }^{102}$ felkelések elleni küzdelmet a konfliktus időtartamának nagy részében harmadik szereplős helyzetből vívta az aktuális nemzetközi koalíció: az afgán és iraki kormányokkal és azok frissen felállított biztonsági erőivel való együttmüködésben. Ezek a harmadik szereplős konfliktusok számos szempontból eltérnek a preklasszikus és klasszikus szakaszban végbement felkelésellenes fellépésektől. Közülük talán a legfontosabb a konfliktusok kontextusa: mind Irakban, mind Afganisztánban különböző okoknál fogva - gyenge központi hatalommal rendelkező állam támogatása volt a cél egy stabilizációs keretrendszerben. Egyik esetben sem felkelésellenes mủveletben való részvételnek indult a koalíciós jelenlét. Ez jelentős ellentét a klasszikus felkelésellenes müveletekhez képest, mivel ott a fennálló berendezkedés védelme volt a cél, nem pedig egy újonnan létrehozott politikai rendszer védelme.

\footnotetext{
${ }^{101}$ Kétféle jogi szabályozás biztosította a koalíciós erők jelenlétét. Egyfelől: 2002-ben írták alá az afgán és az amerikai fél közötti megállapodást, ami lehetővé tette az amerikai jelenlétet. Ez 2003-ban lépett életbe. (Agreement regarding the status of United States military and civilian personnel of the U.S.Department of Defense present in Afghanistan in connection with cooperative efforts in response to terrorism, humanitarian and civic assistance, military training and exercises, and other activities) Másfelöl: az ENSZ BT 1368-as határozata legitimitálta az amerikai katonai jelenlétet (az ISAF jelenlétet pedig az ENSZ BT 1386-os határozata). A későbbiekben kétoldalú megállapodás váltotta fel az ENSZ-felhatalmazást. (Mason [2012] 7-10. o.)

1022004 júniusában az Egyesült Államok átadta a hatalmat az iraki átmeneti kormánynak, és ezzel megszünt a megszállóként gyakorolt politikai jogköre. Így az iraki politikai berendezkedés szerepe vált meghatározóvá ebben a dimenzióban (igaz, az Egyesült Államok és szövetségesei erőteljesen alakították ezt a rendszert a kezdeti szabályozásokkal). Az amerikai erők jelenlétét ENSZ BT 1546-os határozat tette lehetővé, amit több határozattal $(1637,1723,1790)$ egészen 2008. december 31 -ig hosszabbítottak meg. (Mason [2009] 1-3. o.) A későbbiekben kétoldalú megállapodást kötöttek a felek az erők állomásoztatásáról.
} 
A harmadik szereplő ${ }^{103}$ definíciója: „Olyan harcoló erő és politikai szereplő, amely a felkeléssel küzdő ország határain kívülröl érkezik, jelentös konvencionális katonai erökkel ${ }^{104}$ vesz részt a fegyveres konfliktusban, és célja a konfliktusos ország nemzetközileg elfogadott kormányának támogatása; azzal együttmüködésben lép fel a felkeléssel szemben."105 Tanácsadók kiküldését vagy kis létszámú különleges erő bevetését egy kormányzat megsegítésére egy felkelő csoporttal szemben nem lehet felkelésellenes müveleti részvételnek tekinteni (az a FID kategóriájába tartozik).

Alapvető stratégiai lehetőségek a harmadik szereplő előtt, miután megindította a katonai beavatkozását:

- a felkelés kordában tartása katonailag, és közben a felkelés ellen sikerrel fellépni képes katonai erő és államapparátus megerősítése (vagy szükség esetén létrehozása)

- politikai kompromisszum elösegítése a támogatott kormányerök és a felkelők kompromisszumra kész része között

- katonai kivonulás és a konfliktus politikai-katonai kibontakozásának lehetővé tétele (gazdasági és politikai támogatás ettől függetlenül továbbra is fennmaradhat)

A klasszikus értelemben vett „győzelem” elérése a felkelésellenes müveletben vagyis a felkelés katonai eszközökkel való háttérbe szorítása és az állam legitimációjának helyreállítása - a megsegített állam feladata. A siker a harmadik szereplőnek a gyakorlatban azt jelenti, hogy segít az erőszakmonopólium helyreállításában, valamint a politikai folyamatban konstruktív szerepet játszik (közvetítéssel vagy egyéb, a konfliktus sajátosságainak megfelelő feladatok felvállalásával), elősegítve a megsegített állam helyzetének javulását a felkelőkkel szemben.

A sikeres harmadik szereplős fellépés másik kulcsa a legitimáció biztosítása a müvelethez három szinten: a harmadik szereplő belpolitikai terében, a megsegített állam belpolitikai terében, és a szélesebb nemzetközi közösség előtt. Utóbbi szerepe nem elhanyagolható olyan szempontból sem, hogy a beavatkozás hatékony végrehajtásához

\footnotetext{
${ }^{103}$ Maga az elnevezés arra utal, hogy a felkelői és a kormányoldal mellett egy megkülönböztethető, saját érdekekkel rendelkező, kormányoldallal együttmüködő entitás, amely a konfliktusban érintett terület határain kívülről érkezik.

${ }^{104}$ Erin Simspon az 1000 fö feletti csapatküldést tekinti minimumnak. (Simpson [2010] 19. o.)

${ }^{105}$ Ritka, de előfordulhat, hogy egy külső hatalom nyíltan beavatkozik egy felkelés oldalán. Mivel ilyenkor nemzetközi jogilag nem legitim erő támogatására kerül sor, erre célszerübb a beavatkozó hatalom kifejezést használni.
} 
megkerülhetetlen nemzetközi szervezetek ${ }^{106}$ bevonása, illetve szélesebb nemzetközi koalíciók kiépítése, amelyek katonailag, pénzügyileg vagy egyéb módon segítik a műveletet. A beavatkozás legitimitásának széleskörű elfogadása azért is fontos, mert a nem kormányzati szervek - melyek tevékenysége a stabilizációs szakaszban nagy fontossággal bír - egyéb módon nem vonhatóak be a müveletbe. Mindezt olyan médiakörnyezetben kell elérni, amely sokkal kiegyenlítettebb a klasszikus szakaszhoz képest: az internet és a kommunikációs technológia a felkelő csoportok számára is lehetővé teszi, hogy effektív stratégiai kommunikációt folytassanak nemzetközi közönség felé is. (Mackinlay [2005] 59-61. o.)

A stratégiai tér változását jól mutatja, hogy hány szereplő lehet jelen egy felkelésellenes müvelet során különböző szerepekben (természetesen a harmadik szereplő és a megsegített ország szervezetei mellett):

- más országok kormányzati szervezetei (pl.: fejlesztési)

- ENSZ-szervezetek

- nemzetközi szervezetek

- nem kormányzati szervezetek

- kormányzati alvállalkozók (pl.: katonai és biztonsági magáncégek) $)^{107}$

Ezeket a szereplőket a konfliktusra jellemző sajátosságok mentén bonyolult vertikális és horizontális kapcsolatok kötik egymáshoz, amelyek a klasszikus felkelésellenes alaptételt - a civil és a katonai kapacitások hatékony koordinációját nagymértékben megnehezítik, és sokszor ellehetetlenítik. A résztvevő szervezeteknek természetesen mindent meg kell tenniük az együttmüködés megvalósítása érdekében. A cél minden esetben a helyi lakosság együttmüködésének megnyerése. (Mackinlay [2005] 27. o.)

${ }^{106}$ ENSZ-családba tartozó nemzetközi szervezetek különös fontossággal bírhatnak. Olyan eltérő funkciókat ellátó szervezetek tartoznak ide, amelyekre közvetlen szükség lehet a stabilizációs szakaszban (külön előnyt jelenthet például, ha van különmegbízott). Az ENSZ-szervezetek emellett fontos szerepet játszhatnak a humanitárius segítségnyújtásban, a békéltetésben, a választások lebonyolításában stb. Más nemzetközi szervezetek, mint a Nemzetközi Vöröskereszt, a Menekültügyi Szervezet, a Világbank, az IMF és WTO szintén fontos támogatást nyújthatnak a saját területükön. Mivel mindegyiknek független finanszírozása és saját intézményrendszere van, a terhek megosztásához és az átláthatósághoz nagymértékben képesek hozzájárulni. (Mackinlay [2005] 59-61. o.)

${ }^{107}$ Nemcsak az együttmüködés megvalósítása nehéz a színes háttérrel rendelkező szervezetek között. A rossz biztonsági környezetben nehéz a mozgástér biztosítása a feladataik hatékony végrehajtásához anélkül, hogy az egyes aktorok korlátozva éreznék magukat, vagy az ENSZ-szervezetek és humanitárius feladatokat ellátó csoportok a felkelésellenes erő melletti nyílt elköteleződésről tennének tanúbizonyságot, ami ellentétes az intézményi elveikkel. 
Fontos azt is kiemelni a modell kapcsán, hogy a megsegített ország nemcsak partner, hanem sokszor politikai kihívás is. Ennek számos példája lehet, néhány tipikus eset:

- A politikai vezetés korlátozhatja az együttmüködést, kritikus kérdések kapcsán nyilvános kommunikációjában elhatárolódhat a szövetségesétől ${ }^{108}$ stb., ami az együttmüködés hatékonyságát csökkenti.

- A megsegített államnak lehetnek strukturális problémái, amelyek nehezítik a sikeres fellépést, de politikai okokból nehéz öket orvosolni, pl.: korrupció, politikai kirekesztés stb.

- Az aktuális állami kapacitásokon kívül eső, de a kötelességek közé tartozó tevékenység ellátásának hiánya, amihez a megsegített állam vezetése ragaszkodik, szintén az együttmüködés kárára válhat. Ilyenek pl. a nem hatékony igazságügyi rendszer keltette problémák.

- A biztonsági erők kiépítése elé gördített akadályok. ${ }^{109}$

A harmadik szereplőnek emellett arra is oda kell figyelnie, hogy a jelenléte ne legyen a konfliktus mozgatórugója. Egy idegen hatalom jelenléte hathat egyesítőleg a kormányellenes csoportokra. Másfelől azonban egy erős katonai hatalom vagy szövetség jelenléte vezethet ahhoz, hogy megfelelö politikai megoldások hiányában a megsegített állam vezetése ne váljon függővé a harmadik szereplő segítségétől (sem pénzügyi, sem biztonsági, sem egyéb értelemben), mert az hátráltathatja a megsegített állam kapacitásainak kiépítését.

\section{Megváltozott stratégiai tér}

A harmadik szereplős felkelésellenes müveleteket a klasszikus szakasz viszonyaihoz képest erősen megváltozott nemzetközi térben kell végrehajtani, ami számos problémát vet fel. Az önmagában probléma, hogy a nyugati államközi háborús tradíciókkal ellentétben a felkelésekben összemosódnak a katonai és a polgári keretek. A stratégiai tér, amiben a konfliktus megvívásra kerül, egy sokkal szélesebb fizikai és virtuális tér, mint volt korábban.

\footnotetext{
${ }^{108}$ Karzai elnök pl. számos alkalommal bírálta az amerikai és NATO különleges erők éjszakai bevetéseit. Az ilyen kijelentések alkalmasak a közvélemény szimpátiájának legalább átmeneti megszerzésére és a politikai vezetés függetlenségének „mutogatására”.

${ }^{109}$ Személyi kérdésekben politikai preferenciák érvényesítése a hatékonysággal szemben, átgondolatlan fejlesztések stb.
} 
A stratégiai térbe beletartozhatnak ma már olyan területek, ahol az érintett lakosság kitelepült része nagy számban van jelen; beletartoznak a hadianyagok vagy egyéb fontos eszközök szállításában érintett országok légterei, vízi és szárazföldi szállítási útvonalai; ${ }^{110}$ az érintett aktorok és intézmények által azonosított stratégiai tér; migráns vagy helyi közösségek, amelyek politikai vagy ideológiai szempontból érintettek a konfliktusban; azok az államok, amelyek csapatokat küldtek a konfliktus megvívására, vagy egyéb módon járultak hozzá. Szintén ide tartozik a konfliktusban érintett globális, regionális és nemzetközi szervezetek vezetése. Emiatt egy hatékony felkelésellenes stratégiának célba kell vennie a felkelők határokon átnyúló szervezeti rendszerét, miközben a saját érdekeit védi. (Mackinlay [2005] 36. o.)

Így a konfliktus határain túli események is jelentős hatással lehetnek a konfliktusra, ezért nemcsak a müveleti területen élő lakosság, hanem az azon túli lakosság szimpátiájának, vagy legalább semlegességének biztosítása is fontos szempont lehet. A stratégiai tér kiszélesülése így nemcsak a harmadik szereplő, hanem a felkelő számára is valóság, az információs technológia pedig új mélységet is biztosít a felkelői oldalnak.

Mackinlay ezt virtuális dimenziónak nevezi, és az emberek elméjéért vívott harcként jellemzi. A virtuális dimenzió a teljes képalkotási, hírgyüjtési és terjesztési folyamatra vonatkozik, ami az érintett csoportok percepcióit alakítja. A virtuális dimenziónak két csoportját különbözteti meg:

1. kereskedelmi alapú hírszolgálatok, amelyek a virtuális dimenzió szabályozott részét jelentik,

2. „vírus aktorok”, akiknek a tevékenységét senki nem szabályozza, és ugyanazoknak az eseményeknek a nem hivatalos, kevéssé megbízható vetületeit közvetítik a maguk módján.

A kettő össze is kapcsolódhat. A támadások valódi hatását nem az okozott fizikai kár adja, hanem az abból következő politikai és érzelmi reakció. Ezt a második csoport (kisebb célcsoportokra bontva) hatékonyabban képes megszólítani. ${ }^{111}$ Mackinlay szerint ez teljes mértékben szabályozatlan dimenzió, így nem lehet azonosítani az információs

\footnotetext{
${ }^{110}$ Afganisztán kitünő példa ennek alátámasztására. A NATO-erőknek nem kis fáradtságba, politikai kompromisszumkészségbe került, hogy biztosítani tudják a hadianyagok szállítását. A pakisztáni, a kirgizisztáni Manas légibázis körüli és az oroszokkal való megállapodási nehézségek, illetve az Irán ellen érvényben lévő szankciók miatti szállítási tilalom nagymértékben megdrágította és megnehezítette a NATO-erők ellátását.

${ }^{111}$ A virtuális térben elért sikerek: a közvélemény befolyásolása, választási eredmények befolyásolása, megváltozott piaci viszonyok, (előforduló) zavargások és a lakossági segítség mértéke a kormánynak és a felkelőnek (Mackinlay [2005] 37. o.)
} 
hadviseléssel, és sajátos hatása, hogy a taktikai és a stratégiai szintek közötti távolságot nagymértékben képes csökkenteni. (Mackinlay [2005] 37-38. o.)

\section{A harmadik szereplő és katonai kihívásai, strukturális problémái}

Simpson szerint a harmadik szereplős modellnek számos olyan buktatója van a hagyományos kétszereplös felálláshoz képest, ami a siker esélyét csökkenti, annak ellenére, hogy a harmadik szereplő általában katonailag és gazdaságilag erős hatalom. Ezek:

- Információs deficit: a harmadik szereplő nem rendelkezik megfelelő információkkal a hadszíntérről ahhoz, hogy reális képet alkothasson a felkelők képességeiről és a támogatást igénylő kormányzat valódi helyzetéről.

- Katonai deficit: bár a harmadik szereplő katonailag erős aktor, de az erőt csak konvencionális értelemben képes létrehozni és alkalmazni; a felkelésellenes hadviseléshez szükséges doktrína, felszerelés stb. általában nem áll rendelkezésre a beavatkozás megindításakor. (Simpson [2010] 32-33. o.)

- Politikai deficit: a beavatkozás sikere nem fenyegeti közvetlenül a harmadik szereplő biztonságát, de a háború menedzselése, vagyis a hazai politikai támogatás megőrzése fontos szerepet kap. (Simpson [2010] 35. o.)

- Stratégiai deficit: a siker nagymértékben függ a támogatott kormány teljesítményétől. Amennyiben rosszul teljesít, és elveszíti a legitimációját, a harmadik szereplő számára nagyon nehéz lesz úgy befejezni a konfliktust, hogy ne tünjön vereségnek az otthoni és nemzetközi közvélemény szemében. (Simpson [2010] 36-37. o.)

A politikai és a stratégiai deficit között szoros összefüggés van, mivel a külső hatalomnak nyilvánvaló fenyegetés hiányában nehéz az erejét teljes mértékben mozgósítani egy gyengébb ellenséggel szemben. Ehhez járul még, hogy a harmadik szereplő katonai kötelezettségei és érdekei megoszlanak, és nemzetközi, illetve belpolitikai szempontból hátrányokat rejt magában a túlzott erő alkalmazásának látszata, illetve más kötelezettségek elhanyagolása. Ehhez szorosan kapcsolódik a konfliktus morális megítélése a hazai és nemzetközi közvéleményben: a második világháborúban pl. a stratégiai bombázás elfogadható volt, míg Vietnam esetében erkölcstelennek mondták, és ennek megfelelően aláásta a háború belpolitikai támogatását. (Mack [1975] 186. о.) 
A nehézségek közé lehet még sorolni az „előre nem látható problémák” deficitjét. Ezek közül a legnyilvánvalóbb, hogy egy harmadik szereplő beavatkozása új minőséget adhat egy belső konfliktusnak, mivel kormányellenes csoportokat egyesíthet egy idegen fegyveres erő megjelenése (ellentétben a harmadik szereplő közvéleményével, amire egy ilyen akció igen megosztólag hathat). Mack ezt a jelenséget indirekt kohéziónak nevezi. (Mack [1975] 182-183. o.)

A katonai deficit összetett jelenséget takar. Kézenfekvő része a taktikai szinten jelentkező nehézségek sora, ami a nyelvi és kulturális különbségekböl, jogi korlátokból, személyes kapcsolatok nehézségeiből fakad az említett információs deficit mellett.

A katonai deficitet egy fontos strukturális változás is növeli. A második világháború után jelentős változások következtek be a nyugati országok hadseregeinek struktúrájában. Ez olyan képességek elvesztésével járt, amelyek békeidőben feleslegesek és egy konvencionális háborúban már nem lennének fontosak, de egy felkelésellenes müveletben nagy előnyt jelenthetnének. Kitson az elveszett képességek közé sorolta a kikötők, vasutak, erőmüvek, csatornarendszerek üzemeltetésére, valamint a bányák és egyéb ipari létesítmények müködtetésére alkalmas egységek felszámolását. (Kitson [1991] 187. o.) Ez a trend napjainkig folytatódik, illetve erösödik egyes feladatok magánvállalkozókhoz való kiszervezésével. Mindez ahhoz vezet, hogy konvencionális értelemben (papíron) nő a fegyveres erők hatékonysága és a költségek csökkennek, a gyakorlatban azonban a mindenkori katonai vezetésnek komoly hiányosságokkal kell számolnia.

A politikai deficit és a katonai deficit is összekapcsolódik az erőszak alkalmazásáról szóló vitákban a harmadik szereplő esetében. A konvencionális államközi háború és a felkelésellenes müveletek sokszor ellentétes igényeket támasztanak. Ilyen a nagyobb létszámú lövész egységek szükségessége és a decentralizáltabb fellépés, amely egy magas technikai színvonalú, magas egységekkel vívott háború igényeivel nincs összhangban. Ennek következtében kialakult egy manőverező szemszögü konvencionális elfogultság, ami a felkelésellenes műveletekben való részvételt előnytelennek tartja. Már Kitson rámutatott arra, hogy a konvencionális háború megvívására készülő katonai erők vezetése sokszor nem elég rugalmas, hogy megvizsgálja azokat a feladatokat és igényeket, amelyek egy felkelésellenes műveletben megkerülhetetlenek. Ez arra vezethető vissza, hogy a két konfliktus által a katonákkal szemben támasztott követelmények ellentétesek: míg az egyik közvetlen fellépést és agresszivitást igényel, addig a másik ravaszságot, türelmet és eltökéltséget kíván. Az 
volt a véleménye, hogy aki nem képes váltani, az hátráltatja a célok elérését. (Kitson [1991] 199-201. o.)

Galula ehhez hozzáteszi, hogy a felkelésellenes műveletekben az átmenetek sosem egyértelműek, és a katonai fellépés csak része az egésznek. A felkelésellenes műveletek gyakorlati oktatása ráadásul sok nehézséget vet fel, mert a helyzeteket nem lehet modellezni. (Galula [1964] 62-63. o.) Szerinte a politikamentesség elve is választóvonalat képez a konvencionális és a felkelésellenes felfogás között. A politikamentesség régi hagyomány, amihez ragaszkodnak a demokratikus országok fegyveres erői. A felkelésellenes hadviselésben viszont éppen az erők átpolitizálására van szükség annak érdekében, hogy a lakossággal hatékony kapcsolatot tudjanak tartani, és el tudják érni a kitüzött politikai célokat. A felkelésellenes hadviselés feltételeinek megfelelő fellépés nem feltétlenül szolgálja egy tiszt előrejutását egy olyan hadseregben, amely ragaszkodik a régi értékekhez, és ez furcsa kettősséget eredményez. (Galula [1964] 53. o.)

További nehézség, hogy a konvencionális háborúra kifejlesztett fegyverek nem megfelelőek a gerillaellenes müveletekre. A fegyverek egy részének (mint pl. a hátrasiklás nélküli lövegeknek) nehézkes a használata, ugyanakkor komoly károkat okozhat a kormányoldalnak, ha müködőképesen kerülnek a felkelők kezére. (Thompson [1966] 62. о.)

A képességbeli problémák kiküszöbölésére és a létszámproblémák megoldására vonatkozó trend a koalíciók alakítása, amelyek katonai ${ }^{112}$ és civil dimenzióval is rendelkeznek. Ezeknek a nemzetközi koalícióknak a helyzete olyan szempontból hasonlít a felkelőkére, hogy a szereplők közötti kapcsolat strukturálatlan és horizontális (ld. a humanitárius és a kormányzati civil és katonai szervek kapcsolata), de nincs ideológiai kötődés, mint a felkelőknél, hogy hatékonnyá váljon az együttműködés. A problémákat Mackinlay az alábbi pontokban foglalja össze:

- A kapcsolat a humanitárius és a katonai fél között a mai napig nem kellően rendezett.

- A dinamikus katonai fellépést így egy kevéssé dinamikus civil fellépés követi a stabilizációs szakaszban.

\footnotetext{
${ }^{112}$ A katonai segítségnyújtás is komoly megszorításokat rejthet magában. Az utóbbi évek gyakorlata az volt, hogy egyes országok szigorú politikai kontroll mellett, a közvélemény érzékenységének szem elött tartásával korlátozták a harci feladatokban való részvételt, és ezzel csökkentették a hozzájárulás tényleges hatékonyságát.
} 
- A tervezésnél katonai szempontból erősokszorozóként tekintenek a humanitárius szervezetekre, amelyek teljes mértékben elkülönített entitásnak tartják magukat. Így a katonai-politikai és a humanitárius oldalnak eltérő elképzelései vannak arról, hogy mi történik és mit kellene tenni. A humanitárius oldal mindent megtesz annak érdekében, hogy a látszatát is elkerülje annak, hogy egy ellenstratégia része. (Mackinlay [2005] 64. o.)

Mindezek figyelembe vételével a hagyományos fogalmak átértékelésre szorulnak a harmadik szereplős környezetben. Egy harmadik szereplő csak úgy lehet sikeres egy konfliktusban, ha megfelelő módon képes a politikai és a katonai szükségleteket az érdekekkel összeegyeztetni, és a megsegített állam vezetésével is hatékonyan képes koordinálni. Ennek kapcsán érdemes a stratégiai, müveleti és taktikai hatékonyság fogalmát újradefiniálni:

- Stratégiai hatékonyság: hatékony együttmüködés megteremtése a harmadik szereplő(k) és a megsegített állam biztonsági és közigazgatási vezetése között ${ }^{113}$ a hatékony fellépés érdekében. Ezt a harmadik szereplő(k) és a megsegített ország politikai vezetéseinek célkitüzéseivel összhangban kell megtenni, maximálisan tiszteletben tartva a megsegített állam szuverenitását.

- Mủveleti hatékonyság: a politikai célok operacionalizálása a konfliktus körülményeinek megfelelöen, a politikai céloknak megfelelő intézményi együttmüködés kialakítása, a szükségletek felmérése, megfelelő katonai és civil személyi állomány, valamint pénzügyi és egyéb források elérhetővé tétele a felkelő erők képességeinek és lehetőségeinek maximális figyelembe vétele mellett. Ha szükséges, figyelmet kell fordítani a civil és katonai intézményi kapacitások létrehozására vagy bővítésére a feladatok hatékony ellátása érdekében.

- Taktikai hatékonyság: a megfelelő egyensúly megteremtése az offenzív, defenzív, stabilizációs, kiképző és mentoráló feladatok között, melynek nyomán a harmadik szereplő(k) politikai céljai és a megsegített ország céljai, illetve szuverenitása nem sérül.

\footnotetext{
${ }^{113}$ Ennek természetesen előfeltétele, hogy a harmadik szereplő katonai és politikai vezetése között mélyreható párbeszéd legyen a siker igényeivel és a kudarc következményeivel kapcsolatban, melynek nyomán reális, a rendelkezésre álló képességekkel megvalósítható célokat fogalmaznak meg.
} 


\section{A harmadik szereplő politikai hatékonysága}

A politikai hatékonyság meghatározása összetett probléma. Először a politikai deficit problémáját érdemes körüljárni, ami egyfajta politikai korlátozó tényező a harmadik szereplőre nézve. Három nagyobb részre osztható: a harmadik szereplő belpolitikai tere, együttmüködés a megsegített országgal és a szélesebb nemzetközi kontextus.

Belpolitikai korlát: a harmadik szereplő közvetlen fenyegetés hiányában az erő alkalmazásában korlátozva van, aminek alapvetően politikai okai vannak. A háborús tematika a belpolitikai viszonyok átrendeződéséhez vezethet, amit elkerülhetetlenné tesznek a gazdasági terhek és az információs környezet. Így a belpolitikai összhang nem automatikus, a támogatás fenntartása az idő előrehaladtával egyre nehezebb. A kormányzati információs deficitnek és a felkelések általánosan elhúzódó jellegének következtében egy ilyen külföldi katonai-politikai fellépés komoly belpolitikai problémává válhat. Emiatt a harmadik szereplő minden katonája stratégiai tizedessé vagy katonává válik: ha téves vagy elhibázott lépést tesznek a szüken vett területükön és ez nyilvánosságra kerül, annak az egész vállalkozásra nézve komoly stratégiai és politikai következményei lehetnek.

Gil Merom három főbb tényezőt különböztet meg a belpolitikai korlátok terén, amikre egy demokratikus vezetésnek figyelni kell:

- Instrumentális dependencia: azt fejezi ki, hogy a politikai vezetés milyen mértékben függ a társadalomtól a háborús erőfeszítés biztosításához szükséges erőforrások tekintetében. (Merom [2003] 18. o.) - Ezen a téren a klasszikus szakaszhoz képest javulás következett be a tömeghadseregről professzionális hadseregre való áttéréssel, de anyagi értelemben még mindig jelentős tényező.

- Normatív különbség: a kormány és az általában liberális ellenzék közötti szakadás mértéke a beavatkozás legitimitása és az alkalmazandó erőszak mértéke között. (Merom [2003] 18. o.)

- Politikai relevancia: a társadalmi érdekcsoportok azon képessége, hogy hatékonyan tudják befolyásolni a politikai folyamatokat. Merom ezt alapvetően társadalmi csoportokhoz köti, amelyek a demokratikus rendszerekben képesek a 
diskurzust befolyásolni és választók útján nyomást gyakorolni a politikai vezetésre. $^{114}$ (Merom [2003] 18-19. o.)

A felsorolt három tényező együttese határozza meg a társadalmi nyomásgyakorlás lehetséges módjait a harmadik szereplő katonai szerepvállalásával szemben. Azonban a harmadik szereplő politikai berendezkedésén is múlik, hogy mekkora a fentebb felsorolt tényezők súlya. Alacsony bejutási küszöbü parlamenti demokráciánál sokkal hamarabb okozhat gondot egy elhúzódó válság, mint a stabil intézményrendszerrel bíró amerikai típusú elnöki rendszerben, ahol az elnöki mandátum idejére a külpolitika jelentős autonómiát élvez. A különböző politikai berendezkedések eltérő mértékben teszik lehetővé a háború tematizálását is.

A fenti mechanizmusok kapcsán és a konfliktus jellegéből - egy erősebb fél harca egy gyengébb ellen, ami jelentős anyagi áldozatokkal járhat - adódóan, gyakran felvetődik a kérdés, hogy kell-e demokratikus korlátról beszélni? Vajon az említett politikai korlátok jobban érintenek-e egy demokráciát, mint egy diktatúrát? Ezekre a kérdésekre a gyarmati hatalmak tapasztalatai, illetve az elmúlt évek felkelésellenes müveleteinek tanulságai alapján nem lehet egyértelmü választ adni. Nem demokratikus berendezkedésü államok is szenvedtek harmadik szereplőként vereséget felkelésekkel szemben - példa erre a Szovjetunió afganisztáni szerepvállalásának vagy Nasszer elnök jemeni beavatkozásának kudarca. És demokratikus berendezkedésű államokban is nem egy esetben előfordult, hogy bár hangos volt a háborúellenes tábor, jelentős politikai áldozatok árán fenntarthatónak bizonyult a szereplés.

A politikai támogatás mértéke elválaszthatatlan az erőszak alkalmazásának módjától. A politikai célokkal nem kellően összehangolt erőszak-alkalmazás könnyen vezethet kudarchoz (erre a franciák korábban tárgyalt algériai fellépése jó példa). Mack a politikai akarat megszünését nem elsősorban a rossz katonai vezetésre vezeti vissza. Sokkal inkább a konfliktus struktúrája és az ellenségek konfliktusos kapcsolata az ok. Ahol a háborút korlátozottnak fogják fel, mert az ellenség gyenge, a háború nem követelhet teljes erőfeszítést (totális háborúban nincs fegyver és vaj kérdés,

\footnotetext{
${ }^{114}$ A három faktor azonban nem egyszerre érett be. Az instrumentális dependencia már a 19. században létrejött a tömeghadseregek megszervezésével, a releváns csoportok és közönségek mérete csak a 20 századra nőtt meg kellő mértékben ahhoz, hogy hatékonyan képes legyen befolyásolni a külpolitikai törekvéseket. Az első és a második világháború megváltoztatta a háborúról korábban kialakított magasztos képet. Az első világháború elvette a nemességét és a romantikáját, a második ezt erősítette. A háborús bűnök megfogalmazásával új szabályok léptek életbe. (Merom [2003] 76-78. o.)
} 
automatikusan a fegyverek kapnak prioritást). (Mack [1975] 184. o.) Másfelől a civilek elleni erőszak, legyen az akár véletlen, általában negatív hatású. ${ }^{115}$

Ami a harmadik szereplő szempontjából politikailag nehéznek bizonyult, az a támogatott országgal ápolt kapcsolat alakulása volt a részvétel ideje alatt. A harmadik szereplő mozgásterét a konfliktusban implicit és az explicit politikai korlátozó tényezők határozzák meg. Implicit tényezők a mindenkori nemzetközi jogi normák, szokások, a saját ország hadikultúrája által megkövetelt fellépés, a megsegített országgal megkötött formális vagy informális megállapodások. Az explicit tényezők olyan politikailag ki nem mondott megkötések, amelyek a háború politikai fenntarthatóságát szolgálják a hazai (és ha kell, nemzetközi) közvélemény előtt. Mind az explicit, mind az implicit politikai korlátok csökkenthetik a szorosabb értelemben vett katonai hatékonyságot a taktikai szinten. (Implicit korlátozó tényező a gyarmattartói múlt öröksége, vagy az imperializmussal való azonosítás egy demokrácia esetében.)

Az explicit tényezők meghatározásánál az egyik legfontosabb és legtöbbet vizsgált tényező a katonai veszteségek kérdése. A stratégiai hatékonyság növelése elméletben elérhető a taktikai hatékonyság csökkentése árán. A harcoló erők nagyobb tüzerő alkalmazásával és defenzívebb megközelítéssel csökkenthetik a saját veszteségeiket, de ez általában nagyobb polgári veszteségekkel jár, ami a harmadik szereplő és a megsegített ország között feszültségekhez vezethet, illetve hátráltatja a megsegített állam legitimációjának kiterjesztését, rossz színben tünteti fel a harmadik szereplő katonai erőit nemzetközileg, és a felkelői propagandának jó talajt adhat. Összegezve: a túlzott erő alkalmazás a veszteségek csökkentésére a nemzetközi és a megsegített ország közvéleménye előtti politikai hatékonyság csökkenéséhez vezethet, ami hosszú távon csökkenti a konfliktus harmadik szereplője számára kedvező végkimenet megvalósulását.

Merom szerint két tényező miatt nőhet meg a normatív különbség: a veszteségek nagymértékü növekedése miatt, vagy amiatt, hogy a túlzott mértékű erőszakról szóló információk elérik a közvéleményt. A demokratikus berendezkedésű harmadik szereplőknek ezért határozottan kell a céljaikat követni. ${ }^{116}$ A harmadik szereplő belső

\footnotetext{
${ }^{115}$ Erre a jelenségre számos példát lehet hozni a közelmúltból. A legkézenfekvőbb az Abu Ghraib botrány, amikor az iraki foglyokat embertelen bánásmódnak tették ki. Nyilvánvalóan megsértették a foglyokkal való bánásmód szabályait, a felelősségük nem volt vitatható.

${ }^{116}$ Merom szerint előfordulhat, hogy demokratikus vezetések annak érdekében, hogy elkerüljék a normatív különbség növekedését, megtévesztéshez és a despotikus megoldásokhoz nyúlhatnak, az ilyen fellépés azonban éppen a harmadik szereplő demokratikus berendezkedésének alapelveit kérdőjelezi meg. (Merom [2003] 22. o.)
} 
politikai konfliktusai motiválhatják a felkelőket, megpróbálhatják olyan viselkedésre kényszeríteni az országot, ami a közvéleménye elött negatív hatást vált ki (Merom [2003] 22-23. o.) Emiatt általában két reakció várható:

- Az instrumentális dependencia növelésének ellensúlyozására plusz tüzerő és egyéb erélyes eszközök alkalmazása. Ez vonzó lehetőség, azonban tovább csökkentheti közvélemény türéshatárát a háború iránt, amennyiben annak immorális volta általánosan elfogadottá válik.

- A veszteségek - és ezáltal a politikai nyomás - csökkentésére a harmadik szereplő defenzívebb megközelítésre válthat a harcoló erők alkalmazásánál, amivel a gyakorlatban a felkelőknek adja át a kezdeményezést. (Merom [2003] 24. o.)

A harmadik szereplőnek emellett képesnek kell lennie a korábban vázolt deficiteken való felülemelkedésre a siker érdekében. Ezek közül az információs deficit olyan korlátozó tényező, aminek a megszüntetése elsődleges fontosságú a harmadik szereplő számára. El kell döntenie, hogy kizárólag a megsegített ország hírszerzési információira támaszkodik, vagy létrehoz egy saját szervezetet, hogy független forrásból is tudjon tájékozódni a kialakult helyzetről. Kitson szerint előre lehetetlen döntést hozni, mivel az kontextusfüggő. (Kitson [1991] 75. o.) A döntés hatása a két fél közti bizalomra egyáltalán nem elhanyagolható.

Thompson a harmadik fél és a megsegített ország közötti együttmüködési problémákra hívta fel a figyelmet. Szerinte fontos feszültségforrás lehet a segély növelésének igénye a megsegített ország részéről, mert bizonytalanná teheti a meglévő programokat. A megemelt segély a stratégia felborulásához is vezethet. Thompson óv a szakértőktől is, mivel szerinte sokszor szük látókörüek, és megvannak a saját kedvenc projektjeik, amelyeket be akarnak fejezni, tekintet nélkül a hatásukra. Gyakori jelenség az is, hogy a fogadó ország megpróbálja egymás ellen kijátszani a támogatást nyújtó ország szervezeteit. (Thompson [1966] 159. o.)

A harmadik szereplő is követhet el hibákat. Thompson szerint ilyen a segélyek visszatartásával való fenyegetőzés, amivel általában reformokat akarnak kierőszakolni. A reformok végrehajtásához időre van szükség, nem szabad sokat várni a segélyek hatásától. A helyi körülményeket mindig figyelembe kell venni. A támogató állam szervezeteinek nem szabad átvenni a támogatott állam szervezeteinek feladatait azért, mert jobban tudják csinálni. A cél a támogatandó állam közigazgatási szervezetének felépítése és hatékony müködtetése. Ennek elérésre nem szabad erőltetett lépéseket 
tenni, az hibákhoz vezethet. Fontos a segélyprogramok méretének és a közigazgatási dolgozók képzésének összhangba hozása, e nélkül aránytalan és rosszul müködő rendszer jön létre, amit az állam valószínüleg nem is tud fenntartani külföldi segélyek nélkül. Ezért olyan kisebb segélyprogramok kellenek, amiket össze lehet kötni megtisztító és megtartó mủveletekkel. (Thompson [1966] 160-163. o.)

A stratégiai hatékonyság vizsgálatánál nem szabad figyelmen kívül hagyni a megsegített ország korlátozott abszorpciós képességét a segélyek terén. A nagyzoló projektek túlzott terhelést jelentenek a közigazgatási szervezetnek. Thompson szerint „a fö funkció az ország kormányzása és adminisztrációja, nem pedig a külföldi segélyek üzletláncszerü továbbosztása.” (Thompson [1966] 164. o.) Ha a támogatott ország vesztésre áll, a támogató országnak csökkentenie és racionalizálnia kell a támogatást. Támogatás nyújtásánál mindig a kitüzött célok teljesítését kell szem előtt tartani. Kerülni kell a kísérletezést, ami csak mélyebben belerántja a támogató országot a konfliktusba, a siker esélyének növelése nélkül.

Megfelelő rendszert kell kidolgozni a sikerek és kudarcok mérésére, a harcérintkezésekből leszürhető adatok nem elegendőek. Thompson szerint a két legjobb mutató a lakosság által önként szolgáltatott jó minőségü hírszerzési információ és a felkelők csökkenő toborzási rátája. (Thompson [1966] 169-170. o.)

Thompson ezeknek a tényezőknek a fontosságát és téves alkalmazását DélVietnam kapcsán elemezte. Az amerikaiak és a dél-vietnamiak az északról érkező inváziót tartották legfőbb fenyegetésnek, ennek megfelelően egy hatalmas konvencionális hadsereget kezdtek kiépíteni a koreai tapasztalatok alapján. A hatalmas konvencionális hadseregnek hatalmas politikai súlya volt. Diem elnöknek rengeteg idejét és energiáját vitte el a parancsokságok ellenőrzése, a konvencionális megközelítés ugyanakkor egyfajta hadúri megközelítés kialakulásához vezetett a felső vezetésben. A nagy hadsereg gazdasági problémákat is okozott, amihez el kellett fogadni az USA anyagi támogatását, ezért az amerikai elkötelezettség sem volt könnyen megszüntethető. A nagy hadsereg elszívta a legjobb fiatalokat a tisztikarba, a kormányszerveknek meg kellett elégedniük a maradékkal. A konfliktus megindulása után kiderült, hogy a polgári intézmények dolgozói nem felelnek meg az elvárásoknak, ezért katonákkal kezdték őket helyettesíteni (1964-re a háromszáz körzeti vezető között alig volt civil). A hadsereg jelentős infrastruktúrát (közlekedés, kommunikáció, egészségügy stb.) igényelt, ami közös volt a civillel, a hadsereg azonban kizárólagosságra törekedett. Voltak területek pl. rádió, pszichológiai hadviselés -, ahol a hadsereg igyekezett a civil hatóság helyére 
lépni. Röviden: a konvencionálisan szervezett hadsereg azt tette otthon, amit idegen országban megszállóként tett volna, komoly gond volt a katonai fegyelem fenntartása is. A konvencionális hadsereg konvencionális müveletekben gondolkodott, amin nem segített, hogy a felső vezetés gyakran cserélődött, és minden új parancsnok látványos katonai győzelemmel akart magának hírnevet szerezni. (Thompson [1966] 58-60. o.)

A szélesebb nemzetközi közvélemény megnyerése, vagy legalább passzivitásának elérése a már korábban tárgyalt koalíciós mủveleti trendek miatt, valamint a nemzetközi szervezetek bevonásának szükségessége miatt nélkülözhetetlen. Amennyiben a harmadik szereplő a konfliktussal kapcsolatban a saját belső politikai viszonyait képes sikeresen menedzselni, ha demokratikus berendezkedésü, jó eséllyel megkapja a nemzetközi közvélemény támogatását.

A gyakorlatban ennek alapján azt mondhatjuk, hogy a harmadik szereplős modellben a különböző deficitek olyan jelentős politikai aszimmetriává adódnak össze, amely hatékony politikai-katonai együttmüködést igényel a hatások menedzselésére. Merom véleménye szerint a demokráciák végső soron azért veszítenek az ilyen jellegü konfliktusokban, ${ }^{117}$ mert nem képesek megtalálni a megfelelő egyensúlyt a költségek és az alkalmazott eröszak foka között. ${ }^{118}$ (Merom [2003] 24. o.) A lakosságközpontú felkelésellenes megközelítés adhat életképes alternatívát a demokratikus berendezkedésű harmadik erőnek, amit azonban megfelelő politikai-katonai keretrendszerbe kell foglalni, lehetővé téve a katonai deficit csökkentését. A hatékonyság biztosításához olyan doktrína kidolgozására van szükség, amely képes megfelelően behatárolni az erőszak alkalmazását.

\footnotetext{
117 Merom a második világháborút és az azt követő változásokat tekinti fontos töréspontnak a nyugati államok történetében: „,(...) a második világháború után a nyugati hatalmak magas szintü instrumentális dependenciája kevésbé vált manipulálhatóvá, mint korábban, és a politikai relevancia és a normatív differencia is jelentösen eltért attól, amilyen pár évtizeddel korábban volt. A szükségszerüsége annak, hogy egyre inkább saját nemzetiségü eröket kellett bevetni, az információs monopólium megszerzésének kudarca a társadalom informálására, a hadszíntér hosszú időre való elszigetelésének képtelensége és a liberális értékrend folyamatos spill-over hatása a társadalomról a hadseregre és a közigazgatásra csökkente az állam azon képességét, hogy , elrejtse” a háborúkat a társadalom elöl. Összességében így az instrumentális dependencia befolyásolási kapacitásában, a társadalomban a politikailag releváns erök méretében és természetében, és a normatív szakadék méretében és természetében bekövetkezett változások eredményeként az ilyen háborúk sorsát már nem katonai meggondolások dominálták.” (Merom [2003] 79-80. o.)

${ }^{118}$ Az elégedetlenség ellensúlyozására Merom több stratégiát is leír:

- Összehangolás: az eltérő célok és eszközök összehangolása a tiltakozások csökkentésére (a háborúellenes táborral szemben a saját támogatók mozgósítása)

- a politikai ár menedzselése (pl.: harctéri szabályok megváltoztatása)

- kompromisszum,

- áldozat,

- a cél feladása (Merom [2003] 66-67. o.)
} 


\section{A megsegített ország kulturális sajátosságai jelentette kihívások}

A harmadik szereplős felkelésellenes müveletekben nagyon fontos, hogy a harmadik szereplő hogyan viszonyul ahhoz a kultúrához, ahol katonai erőt kell bevetnie. Patrick Porter szerint manapság a leegyszerüsítő kultúramegközelítések jöttek divatba, amelyek inkább hátráltatják, mint segítik a probléma megoldását. Leegyszerüsített statikus képet adnak, figyelmen kívül hagyják az interakciók révén létrejött változásokat. (Porter [2009] 55-56. o.) Jó példa erre a tálibokról kialakított kép, mely szerint nem hajlandóak használni a modern technikát. Antonio Giustozzi 2008-ban megjelent munkája már egy teljesen másmilyen neotálib mozgalomról szól. Ez a mozgalom mindenféle technológiai lehetőséget bevonva egy kifinomult propagandahadjáratba kezdett az országban állomásozó külföldi csapatokkal szemben. Zenés és videós CD-ket és DVD-ket adtak ki, amelyeken indokolják a lépéseiket és próbálják lejáratni az ellenségeiket. (Giustozzi [2008] 121-122. o.) Mára a tálib mozgalomnak kiterjedt on-line jelenléte van.

A tálib mozgalom nemcsak ezen a téren volt képes a változásra. Szabálykódexében a Mao által megfogalmazott viselkedési szabályokhoz nagyon hasonló szabályokat találhatunk. ${ }^{119}$ Például:

„5. Ha egy személy megszakitja a kapcsolatait a hitetlenekkel, és a mudzsahidek garanciákat adnak a személyes biztonságát illetöen, és ezt a személyt egy mudzsahid megöli vagy megsebesiti valamilyen módon, az elkövetö személyt nem támogatja az iszlám mozgalom, és a sharia törvényeinek megfelelö büntetésben fog részesülni.

15. Ha egy tisztviselö vagy személy visszaél mudzsahid voltával, és kárt okoz a közösségnek, akkor a közvetlen felettesének joga van a tetteit helyrehozni. Abban az esetben, ha ez nem lehetséges, az ügyet a vezetés elé kell vinni és a mudzsahidek soraiból ki kell öt zárni.

16. A mudzsahidek szigorú utasitása, hogy a lakosságtól nem vehetnek el erövel fegyvert, hacsak nem adott a magasabb vezetés erre utasitást.

17. A mudzsahidek szigorú utasítása, hogy a lakosságtól nem vehetnek el pénzt vagy személyes javakat erővel.” (Combating Terrorism Center [2010])

\footnotetext{
${ }^{119}$ A szabályrendszer tényleges alkalmazása nem általános, de a kidolgozása jelzés értékủ a szélesebb közönség számára.
} 
Ezek alapján kijelenthetjük, hogy a tálib mozgalom a vele kapcsolatban kialakult sztereotípiák ellenére alkalmazkodóképes szervezetté vált, és a nyugati kulturális sztereotípiákat meghazudtolva müködik.

A felkelők kiinduló helyzete annyiban más, hogy jobban ismerik a társadalom etnikai-felekezeti összetételét, így a politikai változások kieszközlésénél kedvezőbb pozícióból indulnak. Porter megállapítja, hogy a kultúra vizsgálata szükséges, de csak kellő óvatossággal és körültekintéssel szabad végezni. Az ilyen vizsgálat a sajátosságok megértése helyett elöítéleteket szülhet, aminek szükségszerüen negatív következményei lesznek. Azt is állítja, hogy a győzelem kulturális előfeltevések és tények kereszteződése, és az elveknek nagy szerepük van a háború végéről alkotott elképzelésekben. Ez nemcsak a nyugati országokra igaz, Bush elnök és Szaddam Husszein egyaránt a saját kulturális félreértéseinek áldozata. (Porter [2009] 56-57. o.)

\section{A felkelések és felkelésellenes müveletek elemzése és politikai nehézségeik}

Egy felkelés elemzése nagymértékben eltér egy konvencionális háború elemzésének módjától. Bár a részletekbe menve mindkettő felettébb bonyolult, az előbbit egyszerübb összekötni a politikai célokkal és a kommunikációval. A konvencionális háborúban az elvesztett vagy megszerzett terület mérete, az okozott kár nagysága és az áldozatok száma jól mutatja az egyszerü polgárnak is, hogy melyik fél áll nyerésre. A felkelésellenes hadviselésnél sokkal nehezebb megtalálni a releváns indikátorokat és mérési eljárásokat. ${ }^{120}$ Azok politikailag relevánssá tétele pedig egy olyan politikai közvélemény felé, amely általában még az államközi konvencionális háborús sajátosságokat tekinti viszonyítási alapnak, sokszor lehetetlen.

Természetesen van relevanciájuk a hagyományos katonai mutatóknak is. Az ellenség, illetve a baráti erők által kezdeményezett tűzharcok, indirekt tűztámadások és egyéb mutatók képet adnak arról, hogy a felkelő fegyveres csoportok mely területekre igyekeznek koncentrálni a tevékenységüket. A fegyveres támadások hatásainak más aspektusait nagyon nehéz mérni. Merényletekkel kapcsolatban a halottak és sebesültek száma és az okozott kár mértéke a mérőszám a legtöbb esetben. A merényletek

\footnotetext{
${ }^{120}$ A katonai téren ez egy bonyolult folyamat a felkelésellenes műveletek mozaik jellegéből adódóan. A gyakorlatban ez azt jelenti, hogy taktikai szinten kell olyan indikátorokat találni, amik országosan is alkalmazhatóak, majd azokat hadmüveleti és végül stratégiai szintű indikátorokká tenni, majd érthetően kommunikálni a lakosság felé a politikai támogatás biztosítása érdekében.
} 
hatásának mérésére alkalmatlanok ezek a számok, mivel nem mutatják meg, hogy egy ilyen akció milyen mértékben könnyíti meg a felkelök mozgását az adott régióban, mennyire félemlíti meg a helyieket, mennyire ösztönzi őket semlegességre vagy nyílt segítségnyújtásra, milyen mértékben aknázza alá az újjáépítésbe és a kormányzatba vetett hitet, miként befolyásolja az ott dolgozó NGO-k munkatársait, mennyire könnyíti meg a biztonsági erőkbe való beszivárgást stb. Ezek mind szubjektív szempontok, amelyeket nagyon nehéz mérni, mégis ezek váltják ki a legfontosabb lehetséges hatásokat. (Harvey [2005] 212-213. o.)

Jelentősége van a gyüjtési szempontnak is. A müveleti és stratégiai szinteken sem könnyü egy felkelésellenes hadjárat áttekintése. A politikai nyomás a sikerek elérésére és a konvencionális mentalitás megzavarhatja a képet a konfliktus tényleges állásáról. Lewis Sorely történész ezt egy vietnami példával illusztrálja: „Amikor az egyik jelentést tevö megjegyezte, hogy az elözö héten nyolcvanhárom indirekt tüztámadás volt DélVietnamban, Davidson azt válaszolta, hogy a korábbi jelentési kritériumok szerint csak a húsz vagy annál több ellenséges rakétával vagy aknagránáttal történt támadást kellett jelenteni. A régi kritériumok szerint a nyolcvanháromból mindössze egy nyilvánult volna támadásnak. „Eszkaláltunk. Eszkaláltuk a jelentéseket!” tört ki Abrams-böl, általános nevetést okozva a teremben." (Sorely [1999] 54-55. o.) Az idézet jól mutatja, hogy mekkora jelentősége van a jelentési rendszernek a vezetés szempontjából. Bár csak konvencionális támadásokról esik szó, a konfliktus menetéről kialakított képet nagymértékben befolyásolja, hogy hol húzzák meg a határt az egyes indikátorok vizsgálatánál. Ha túl magasan vagy túl alacsonyan állapítják meg, akkor félrevezető képet kap a vezetés a konfliktus tulajdonképpeni állásáról.

A szelektív vagy elfogult adatgyüjtésre példa Irakból az IED-kkel (Improvized Explosive Device, improvizált robbanóeszköz) kapcsolatos mérési módszer változása. A kezdeti időszakban csak azokat az IED-ket vették számba, amelyek veszteséget okoztak a koalíciós erőknek. Később, amikor egyértelmüvé vált, hogy az elhelyezett eszközök száma jóval nagyobb, mint a veszteségeké, ez a vizsgálati szempontok kiszélesítését eredményezte, és technikai ellenlépések megtétele helyett az IED-elhelyező és -készítő hálózatokat kezdték támadni. (Guttieri [2010] 143-144. o.)

A civil oldalon lévő mérési problémákra hoz jó példát Stuart Herrington ezredes, vietnami veterán a visszaemlékezésében: „Egy rizstermesztő Hiep Hoa-ban (vietnami körzet) azon kaphatta magát, hogy éjjel egy transzparens alatt ül és egy kormányellenes gyülésen vesz részt, ahol a felháborodott és kizsákmányolt paraszt szerepe jutott neki, a 
kommunista propagandacsoport fürkészö szeme elött. Reggel ugyanaz a termelö elküldheti a gyermekeit az új, kormányzat által felépitett iskolába, hogy utána elmenjen a falusi irodába szavazni - ezúttal a kormányzati tisztviselök fürkésző szeme előtt. A falusi Viet Cong azzal dicsekszik a jelentésében, hogy „a falusiak 90\%-a aktívan támogatja a forradalom ügyét”. Ugyanakkor a Hiep Hoa falusi elöljáró arról tájékoztatja a fönökeit, hogy „több mint 95\%-a a falusiaknak részt vett a választásokon (...)”.” (Herrington [2004] 50. o.) Herrington kifejtette, hogy a vitatott irányítású területeken a konfliktust elszenvedő civilek az ,igen csoporthoz” tartoznak, azt mondják, amit szerintük az öket kérdező hallani akar. (Herrington [2004] 51. o.) Vagyis a közvélemény-kutatásokra csak korlátozottan és megfelelő körültekintéssel lehet támaszkodni.

Egy másik, ugyancsak Vietnammal kapcsolatos példa: McNamara védelmi miniszter egy 1964-es, Johnson elnökhöz intézett memorandumában megvalósítandó politikai célnak mondta a független, nem kommunista Dél-Vietnamot, amelynek nem kell bázisul szolgálni vagy a nyugati szövetségi rendszer tagjává válni. (McNamara [1964]) Ennek katonai erővel való megvalósítása sok szempontból volt problémás: a felkelés és az észak-vietnami fenyegetés elhárítása nem eredményezhetett életképes délvietnami államot. A Diem-időszak után következő kormányok egyike sem volt elég stabil ahhoz, hogy ezt megvalósítsa. Egy absztrakt politikai cél megvalósításához nagyon nehéz megfelelő indikátorokat találni, és a mérés ennek megfelelően lehetetlen.

A felkelésellenes müveletek mérésére is voltak kísérletek. Samuel B. Griffith Mao gerillaháborúról szóló müvéhez írt előszavában az egyik legismertebb kísérletet tette erre. Olyan tényezőket vett alapul, mint a fizikai terep, a kommunikáció és az ellenséges vezetés minősége, a külső anyagi és technikai támogatás megléte, tanácsadók vagy „önkéntesek” részvétele külföldről, aktív menedék megléte, illetve a felkelésellenes erők relatív katonai hatékonysága és politikai rugalmassága. Kidolgozott egy tíz szempontot tartalmazó rendszert ${ }^{121}$, amelyhez 1-től 10-ig terjedő értékeket rendelt a felkelő és a felkelésellenes erő teljesítménye szerint, és ennek alapján egy relatív erőviszony felállítására tett kísérletet. (Mao [1989] 27-31. o.) Ez a rendszer a készítő szakértelmétől és tájékozottságától függően pillanatképet képes adni a konfliktus állásáról.

\footnotetext{
${ }^{121}$ Ezek: a politikai program vonzereje, a lakossági támogatás mértéke, a vezetés minősége, az erők minősége, a katonai hatékonyság, a belső kohézió, a felszerelés, a bázisterület terepének jellege, a bázisterületen a kommunikációs lehetőségek jellege, menedékterület.
} 
Bernard Fall a vietnami konfliktus kapcsán dolgozott ki saját mérési rendszert. aminek a Fall-féle nem katonai indikátorok (Fall Insurgency Nonmilitary Indicators, FINI) nevet adta. A FINI az alábbi elemeket tartalmazta:

\section{4. táblázat Fall-féle nem katonai indikátorok}

\begin{tabular}{|l|l|l|}
\hline \multicolumn{2}{|c|}{ Indikátorok } \\
\hline \multicolumn{1}{|c|}{ katonai } & \multicolumn{1}{|c|}{ nem katonai } \\
\cline { 2 - 3 } & \multicolumn{1}{|c|}{ politikai } & \multicolumn{1}{|c|}{ gazdasági } \\
\hline lineáris mobilitás & \multicolumn{1}{|c|}{ adózási hajlandóság } \\
\hline & \multicolumn{1}{|c|}{} \\
\hline $\begin{array}{l}\text { állami alkalmazottak ellen } \\
\text { végrehajtott merényletek }\end{array}$ & \begin{tabular}{l} 
élelmiszerárak alakulása \\
\hline
\end{tabular} & $\begin{array}{l}\text { belső } \\
\text { alakulása }\end{array}$ \\
\hline
\end{tabular}

Forrás: Fall [1966] 3-12. o.

Fall rendszere megfelelő információk birtokában trendek megállapítására is alkalmas. Egy ténylegesen katonai jellegü szempontot (lineáris mobilitás) tartalmazott, a többi indikátor a szubverzív tevékenységet és a kormány kontrolljának mértékét volt hivatva mérni, ami a konfliktus belső viszonyait illetően előrelépésnek mondható. Ugyancsak előnye, hogy az adatok megfelelő csoportosításával regionális trendeket is meg lehet vele állapítani. Ugyanakkor a Griffith rendszerénél látott potenciális külső dimenziót teljes mértékben figyelmen kívül hagyta. Az is hátránya a rendszernek, hogy egy területre (konkrétan Indokínára) lettek kidolgozva az indikátorok. Földrajzi, történelmi és egyéb sajátosságoktól függően másutt az adózási hajlandóság vagy a belső kereskedelem alakulása nem feltétlenül mond sokat a konfliktus aktuális állásáról.

Mindkét mérési rendszernek hiányossága, hogy a felkelésellenes erő sikerének méréséhez nem adnak megfelelö eszközt.

Érdekes elemzési rendszert tartalmaz az amerikai Központi Hírszerző Hivatal (Central Intelligence Agency, CIA) által kidolgozott anyag, amely feltételezhetően a nyolcvanas években készült a felkelések elemzése céljából. (Aftergood [2009]) Az értékelés szempontjai sokrétüek: a felkelés típusa, a szervezet jellege, a felkelés aktuális fázisa, attitüdök stb. elemzését javasolják. A legérdekesebb rész a kormány 
teljesítményére vonatkozó tizennégy indikátor (hét katonai és hét nem katonai), amelyeket érdemes jobban megismerni:

Katonai faktorok

- Vezetés: A professzionalizmus, amely az ország haderejét jellemzi.

- Taktika és stratégia: A hadsereg azon képessége, hogy az eltérö, nem konvencionális stratégiákat és taktikákat alkalmazza a felkelökkel szemben a gyakorlatban - olyan taktikákat, amelyek elvetik az erők koncentrációját és a tüzerő használatát, és a kis könnyüfegyverzetű katonai csoportok állandó járörözési tevékenységére helyezik a hangsúlyt, amit nagyobb gyorsreagálású egységek támogatnak.

- Katonai hírszerzés: A katonai hírszerzési apparátus azon képessége, hogy összegyüjtse, elemezze és felhasználja a minőségi információkat a gerillákkal szemben, a gerillák fellépésével és létesítményeivel kapcsoltban, de nemcsak a katonai képességeiket illetően.

- Katonák viselkedése és fegyelme: A harcoló katonák és az őket körülvevő lakosság kapcsolata.

- Légi és tengeri müveletek: A tengeri és légi támogatás minősége a kormányzat felkelésellenes erőiben - például tüztámogatás, felderítés, utánpótlás és orvosi segítség.

- Civil-katonai kapcsolatok: A civil hatóságok azon képessége, hogy befolyásolják a katonai müveleteket, mégpedig a politikai okoknak megfelelően.

- Népi milícia: A kormányzat azon képessége, hogy létrehozzon és fenntartson egy népi milíciát, amely segítséget nyújt a reguláris erőknek a biztonság fenntartása érdekében. (CIA [nincs datálva] 13. o.)

Nem katonai faktorok

- Rendöri müveletek: A rendőrség azon képessége, hogy fenntartsa a törvényes rendet, és lakossági, illetve erőforrás-központú korlátozási és ellenőrzési programokat tudjon végrehajtani.

- Civil hírszerzés: A civil és rendőri hírszerzés azon képessége, hogy összegyüjtsenek, koordináljanak, kiértékeljenek és felhasználjanak hírszerzési információkat a felkelőkkel és politikai/katonai tevékenységükkel kapcsolatban.

- Pszichológiai mủveletek: A kormányzat pszichológiai hadviselési mủveletei, információs és médiaaktivitása és azon képessége, hogy az üzeneteit hatékonyan 
tudja eljuttatni otthon és külföldön egyaránt.

- A felkelésellenes fellépés egyesített irányítása: A kormányzat azon képessége, hogy olyan szervezeti infrastruktúrát hozzon létre, amely képes egy koherens felkelésellenes hadjáratot koordinálni.

- Politikai keretrendszer: A kormányzat általános politikai formája, vonzereje és azon állításának alátámasztása, miszerint a lakosság vágyainak és akaratának, valamint az ország hagyományainak és etoszának egyetlen legitim megvalósítója.

- A vidéki állapotok és az adminisztráció javítása: A kormányzat azon képessége, hogy reformokat és programokat hajtson végre annak érdekében, hogy a lakosság nagyobb részének hallgatólagos támogatását megszerezze a felkelőkkel szemben.

- Jogi reform: A kormányzat azon képessége, hogy különleges törvényeket és szabályozásokat vezessen be és tartasson be azzal a céllal, hogy szembeszálljon a felkeléssel és elnyomja azt. (CIA [nincs datálva] 13-14. o.)

A nem katonai faktorok táblázatba foglalva:

\section{5. táblázat Adott kormány teljesítményére vonatkozó nem katonai faktorok}

\begin{tabular}{|l|l|l|l|}
\hline \multicolumn{1}{|c|}{ politikai } & \multicolumn{1}{c|}{ jogi } & gazdasági \\
\hline \multicolumn{1}{|c|}{ biztonsági } & & \\
\hline Rendőri műveletek & & & \\
\hline Civil hírszerzés & & \\
\hline Pszichológiai műveletek & & \\
\hline A felkelésellenes fellépés egyesített irányítása & \\
\hline & Politikai keretrendszer & \\
\hline & $\begin{array}{l}\text { A vidéki állapotok és az adminisztráció } \\
\text { javítása }\end{array}$ & \\
\hline & & Jogi reform & \\
\hline
\end{tabular}

Forrás: CIA [nincs datálva] 13-14. o. 
A harmadik szereplős szempontokat ezeken túl kell a mérési szempontok közé igazítani. A politikai folyamatok megfelelö értékelése is fontos.

Egy téves indikátor megválasztása és politikai alkalmazása rengeteg problémát okozhat. Példa erre a Vietnamban alkalmazott „harcban megölt ellenséges halottak számlálása", ${ }^{122}$ ami eredetileg a harcokban résztvevő ellenség számának becsléssel történő megállapítását célozta. ${ }^{123}$ Számos gonddal járt, pl. nehéz volt kiküszöbölni a kettős számlálást; nem volt retorzió az eltúlzott számok miatt, viszont a túl kevés ellenséges halottnak komoly következményei lehettek az egységre nézve. (Daddis [2011] 96. o.) Azt, hogy milyen civil veszteségek és károk közepette haltak meg, nem mérték. Így történhetett meg, hogy egy idő után az ellenség megölése öncélúvá vált, nem volt kapcsolatban sem politikai, sem pacifikációs célokkal, ugyanakkor jelentős politikai károkat okozó járulékos veszteségekkel járt. (Daddis [2011] 98. o.)

Ehhez jött még a civilek és fegyveresek megkülönböztethetőségének nehézsége, ami szintén a halottlétszám növelésének irányába hatott. A tényleges felmérést tovább nehezítette az amerikai részről alkalmazásra kerülő masszív tüzerő, ami a halottakat olyan mértékben dezintegrálta, hogy sokszor lehetetlenné tette a számlálást. ${ }^{124}$ (Daddis [2011] 102. o.)

Ez a mérési módszer, amely alapvetően a taktikai szintű ellenséggel szembeni sikerek mérésére szolgált volna, más területekre is hatással volt:

- A müveleti hatékonyság mellett az egységek hatékonyságának is fö méröszáma lett.

- Az egységek parancsnokai számára a sikeresség mutatója volt az ellenséges halottak száma, ami így karriereket lendíthetett fel, vagy dönthetett romba.

- A tisztek féléves vagy éves rotációs rendszere következtében a karrierjében elörelépni kívánó tisztnek érdeke volt az ottléte alatti lehető legnagyobb halottlétszám elérése.

\footnotetext{
${ }^{122}$ Wiliam Westmoreland meglátása szerint a „főerők” (vagyis a magasabban szervezett Viet Cong és északi reguláris erők) jelentették a legnagyobb veszélyt, így az amerikai katonai erők fö feladata egyfajta védelmi vonalként való müködés volt, ami lehetővé tette a vietnami erők számára, hogy a pacifikálási feladatokat végrehajtsák. (Daddis [2011] 91-92. o.) Ezért kapott az amerikai stratégiában fontos szerepet az ellenséges áldozatok számának felmérése.

${ }^{123}$ Azoknak a halott katonaképes korú férfiaknak és más személyeknek a számát kellett jelenteni, akiknél fegyvert találtak. Feltételezhető ellenség elvileg nem lehetett a számlálásban. (Daddis [2011] 96. o.)

${ }^{124}$ Ennek is köszönhetően nem volt elkerülhető, hogy a becslések az ellenséges áldozatok számát illetően a rendszer részévé vált. (Daddis [2011] 102-103. o.)
} 
- A nyomás az ellenséges halottak számának növelésére jelentős tüzerő alkalmazását eredményezte, ami érintetlenül hagyta a Viet Conginfrastruktúrát, de elidegenítette a helyieket. (Daddis [2011] 99-101. o.)

További káros hatása, hogy jelentős politikai nyomás nehezedett a katonai vezetésre a konvencionális erők nyílt alkalmazása után megnyíló normatív különbség csökkentésére. Ezért a jelentősebb müveletek után általában a valóságosnál nagyobb áldozatszámok publikálására került sor, ami ennek az indikátornak még a korlátozott alkalmazhatóságát is aláásta. ${ }^{125}$ (Daddis [2011] 99. és 102. o.) A helyi szinten a masszív tűzerő alkalmazásának hatása rendkívül káros volt a gazdaságra és a közösségekre nézve is. (Daddis [2011] 103. o.)

A politikai szinten az optimista jelentések hatását a vezetés nem megfelelően mérte fel. A sikerjelentések az amerikai közvéleményben növekvő eredmények iránti várakozást szültek. Mindez romló sajtókapcsolatokkal párosult, az amerikai sajtó képviselői jelentős gyanakvással fogadták a MACV hivatalos jelentéseit. (Daddis [2011] 132. o.)

A probléma másik része, hogy az ellenséges halottak száma miről terelte el a figyelmet. A mutató semmit sem mondott a Viet Cong vidéki jelenlétéről és aktivitásáról. (Daddis [2011] 103. o.) A MACV kizárólag a katonai szempontokra koncentrált, a saigoni politikai feszültségek nem szerepeltek a számításaiban. (Daddis [2011] 65. o.)

A vietnamizáció előtérbe kerülésével a MACV küldetését megváltoztatták, az ellenség legyőzése helyett a dél-vietnami erők maximális támogatása lett a feladata, ${ }^{126}$ amivel összefüggésben szükség volt az alkalmazott indikátorok felülvizsgálatára is. ${ }^{127}$ (Daddis [2011] 162-163. o.) Ennek keretében „új” mérési terület került az amerikai hadsereg figyelmének a középpontjába: ARVN felkészültségének a mérése. ${ }^{128}$

\footnotetext{
${ }^{125}$ A parancsnoki optimizmus olyan méreteket öltött, hogy a sajtó munkatársai egyenesen félrevezetésről beszéltek. (Daddis [2011] 57. o.)

${ }^{126}$ A vietnamizáció deklarált célja az amerikai erők létszámának csökkentése volt, azonban nem határozták meg pontosan, hogy mik is legyenek a fö hangsúlyok. Így arra sem adtak kielégítő választ, hogy ARVN-t a konvencionális fenyegetéssel való szembenézésre vagy a felkelésellenes mủveletekre kell felkészíteni. (Daddis [2011] 178. o.)

${ }^{127}$ Abrams tábornok, Westmoreland utódja a MACV élén, nem talált domináns indikátorokat az egy háborús politikájához, így a többségüket - köztük az ellenséges halottak számlálását is - változtatás nélkül alkalmazták tovább. (Daddis [2011] 163. o.)

${ }^{128}$ A mérést nehezítették a kulturális és nyelvi nehézségek és az ezeket kompenzáló képzés hiánya. Amerikai kontextusban további nehézséget jelentett a rossz kapcsolat a tanácsadók és a megsegített egységek között. Problémát jelentett a két fél között a rasszizmus is. A gyakori rotáció a kialakult személyes kapcsolatrendszert tette tönkre. (Daddis [2011] 170-171. o.) A félkatonai erök felmérése külön volt kezelve az ún. Területi Erők Felmérési Rendszerében (Territorial Forces Evaluation
} 
Az ARVN létszáma 1968 után megnőtt, a tisztikar minősége és a hadseregben uralkodó állapotok azonban gátolták a növekedés hatékonyságát. A vezetők jelentős része nem rendelkezett kellő vezetési tapasztalattal, mivel 1968 előtt általában csak másodlagos feladatokat bíztak az ARVN-egységekre. Nem volt megfelelő a sorozott állomány bérezése és ellátása, ami növelte a dezertálási kedvet. A morál egyébként is alacsony volt, mivel nem volt megfelelö indoktrinációs folyamat, és alacsony volt a képzés szintje is. (Daddis [2011] 169. o.)

Amerikai részről az ARVN fejlődésének felmérése korábban féléves jelentésekből állt. Ezek a morált és a magabiztosságot nem mérték, de rengeteg statisztikai adatot rögzítettek, mint pl. a teljes létszám, a dezertálási arányok, a kiképzési folyamat, új fegyverek rendszerbe állítása, az ARVN-műveletek nyomán okozott ellenséges veszteségek. (Daddis [2011] 170. o.)

1968-ban Westmoreland tábornok kezdeményezésére kidolgozták a Vietnami Fegyveres Erők Hatékonyságának Felmérési Rendszerét (System for Evaluating the Effectivenes of RVNAF, SEER), ami a hagyományoknak megfelelően erősen kvantifikált rendszer volt, mindent megpróbált mérni (vezetés, kiképzés, morál, felszerelés állapota stb.). ${ }^{129} \mathrm{~A}$ fö probléma mégis az volt, hogy a tanácsadók az amerikai standardok szerint minősítették a vietnami egységek képességeit és teljesítményét, ami torz kép kialakulásához vezetett. Emellett a konvencionális magasabb egységekkel szemben vívott küzdelmeket tekintették mérvadónak, bár tisztában voltak vele, hogy ez nem fordítható le automatikusan a felkelők elleni hatékonysággá. Bár próbálták ezeket a kérdéseket tisztázni, a gyakorlatban semmilyen változás nem történt, az amerikai hadsereg az ARVN-t továbbra is a maga struktúrája szerint építette fel. ${ }^{130}$ (Daddis [2011] 171-172. о.)

Az ARVN-nel kapcsolatos vizsgálatok a harci hatékonyságot tekintették elsődlegesnek, és elhanyagolták a felkelők elleni harcot és a tartós biztonság megteremtésének fontosságát, továbbá a kormány iránti lojalitás kialakítását a lakosság körében. A vietnami kormány hatékonyságának vizsgálata kívül esett a mérési rendszeren. A vidéki területeken a MACV-adatgyüjtés a pacifikációs adatokra

System, TFES), ami statisztikai adatokat és szubjektív értékelést tartalmazott. (Daddis [2011] 171172. o.)

${ }^{129}$ A végrehajtás jelentős adminisztratív terhet rótt az amerikai tanácsadói csoportokra. Nekik kellett felkészíteni a vietnamiakat a támogatott egység teljesítményére vonatkozó 157 kérdésből álló kérdőív kitöltésére. (Daddis [2011] 171. o.)

${ }^{130} \mathrm{Az}$ ARVN állapotának felmérésével kapcsolatban is megjelent a nyomás a pozitív hírek megjelenítésére, mivel a stratégia fontos része lett, és ezt a sajtó felé is igyekeztek megfelelően kommunikálni. (Daddis [2011] 172-173. o.) 
korlátozódott, és nem figyelt arra, hogy különbséget tegyen a fizikai biztonság és a legitimációs kérdések között. (Daddis [2011] 173. o.)

A politikai, katonai és számos más terület adatainak megfelelő mérése fontos egy felkelésellenes müveletben a siker vagy kudarc megállapításához. Fontos, hogy az alkalmazott mérési eljárások konzekvensek legyenek, lehessen megbízhatóan mérni a konfliktus alakulását.

Irakban 2005-2010 között jelentéseket adtak ki a konfliktus aktuális állásáról a törvényhozás és a lakosság tájékoztatására. Ezekben a jelentésekben az idő előrehaladtával eltérő kritériumokat és szempontokat alkalmaztak.

\section{6. táblázat Az iraki jelentésekben alkalmazott indikátorok 2005-2010}

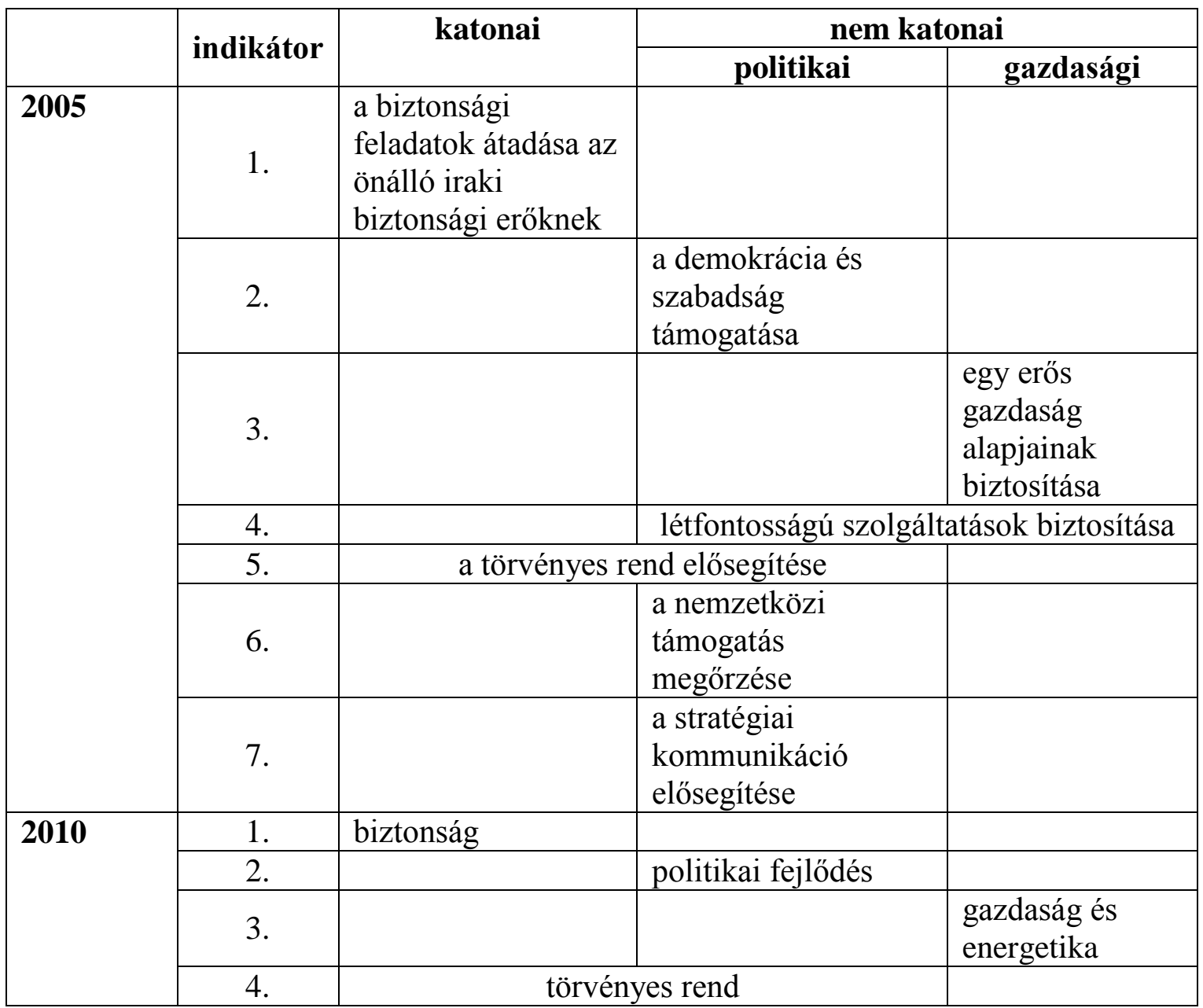

Forrás: (MSSI [2005] 2. o.) és (MSSI [2010] iii. o.) 
A 2005-ös hét viszonylag konkrét indikátorból 2010-re négy átfogó lett. Az egyszerüsítés nevezhető előrelépésnek, de mivel az amerikai kiadványok sem egy definícióval dolgoztak az évek során, ezzel a konfliktus alakulásának irányát nehezebben felismerhetővé tették. Másfelől az olyan fontos tényezőket, mint a síita fegyveres csoportok tevékenysége és a felekezeti erőszak nem mérték a jelentések elkészítéséhez (bár a biztonsági indikátorral lehetett volna), a konfliktus egy fontos mozgatórúgója kimaradt. (Guttieri [2010] 140. o.)

A példák mutatják, milyen nehéz megtalálni és megfelelően mérni a releváns indikátorokat, és hasonlóképpen nehéz, ha éppen nem lehetetlen ezeket politikailag relevánssá és kommunikálhatóvá tenni. Ennek ellenére egy releváns doktrínának minimum a katonai oldalon iránymutatást kell adni arra vonatkozólag, hogy milyen komplex a mérés problémája taktikai, hadmüveleti és stratégiai szinteken. Minden mérés óvatos elemzését igényel. Vizsgálni kell, hogy a konfliktusban résztvevő felek közül melyik van előnyben és miért. Az eredet, az okok, a stratégiák alapos ismerete, valamint minden oldal katonai és politikai képességeinek felmérése szükséges a megbízható végeredmény eléréséhez.

\section{Harmadik szereplös hibák és tévhitek}

Fontos tényező, hogy a harmadik szereplős felkelésellenes fellépésre már csak akkor kerül sor alaphelyzetben, ha a felkelés elég nagy fenyegetéssé nőtte ki magát ahhoz, hogy a beavatkozó ország kormányát komolyan aggassza a sikere. Ez azt is jelenti egyúttal, hogy a felkelés a szervezési szakaszt sikerrel átvészelte, képes volt olyan okokat találni és mozgósító erőt kialakítani, amivel fenyegetést jelentett az államhatalomra.

Vannak olyan hibák, amelyeket egy harmadik szereplőként fellépő ország hadserege könnyen elkövethet a fellépésében és a kommunikációjában. Ezek közé sorolhatjuk a következőket, a teljesség igénye nélkül:

- A politikai és a katonai dimenzió mesterséges elkülönítése.

- A katonai dimenzió erőltetése: A katonai siker sem vezet győzelemre, elég belegondolni Massu tábornok győzelmébe az algíri csatában, és annak következményeibe. A francia hadsereg fellépése elérte a felkelőknek azt, amire önmagukban képtelen voltak - vagyis a tömegek politikai mobilizációját a franciák ellen. 
- A saját katonai erőbe vetett túlzott hit: Az előbbi két ponthoz szorosan kapcsolódó tévhit, melynek alapja általában a konvencionális elfogultság; lényege, hogy kellő mértékü erőalkalmazással felül lehet kerekedni a felkelőkön.

- Technológiai megoldás keresése: A második tévhithez kapcsolható probléma. Lényege a katonai sikerek elérésére való törekvés taktikai szinten, új technológiai megoldásokkal.

- Hibás célkitüzések és a katonai erőalkalmazás korlátainak meg nem értése.

- A megsegített kormány szándékainak, érdekeinek figyelmen kívül hagyása, túlzottan mély beavatkozás a belügyekbe.

- Nagyarányú helyreállítási projektek hangsúlyozása a regionális körülmények és igények, illetve a fenntarthatóság figyelmen kívül hagyásával.

Ezekhez a problémákhoz kapcsolódnak félreértések és tévhitek, amelyek a harc sajátosságaira vezethetők vissza. Az utóbbi években számos ilyennel találkozhattunk. Többségükben onnan erednek, hogy a felkelésellenes müveleteket a politikai dimenziótól és a müveleti realitásoktól elszigetelten elemzik és értékelik. Ismét a teljesség igénye nélkül:

1. A felkelésellenes műveletek egyet jelentenek az államépítéssel.

2. A felkelésellenes mủveletekben az erőszak alkalmazása kerülendő, hátrányos.

3. A hosszú és fáradságos felkelésellenes műveleteket ki lehet váltani konvencionális megközelítéssel.

4. Demokráciák nem tudnak felkelésellenes műveleteket megnyerni.

5. A felkelésellenes műveletek végrehajtása elsősorban a hadsereg feladata.

Az ilyen és ehhez hasonló félreértések a közvélemény formálásában és közvetveközvetlenül a politikai vélemények formálásában is szerepet játszanak, nehezítve az ilyen müveletek végrehajtását. 


\section{FEJEZET \\ KORTÁRS NYUGATI FELKELÉSELLENES DOKTRÍNÁK}

A harmadik szereplős felkelésellenes müveletek fogalma a brit klasszikus szakaszbeli szerzők munkáiban jelenik meg. Mind Thompson, mind Kitson fontos gondolatokat fogalmazott meg az ilyen jellegü fellépés igényeivel és sajátosságaival kapcsolatban.

Kérdés, hogy mennyire relevánsak a munkáik a mai felkelésellenes konfliktusokra. A szerző véleménye szerint hadműveleti szinten relevánsak, bizonyos megkötésekkel. Mint azt láthattuk, jelentős változások mentek végbe mind az információs környezetben, mind a felkelések politikai-gazdasági modelljében, így a taktikai ajánlások ma már kevéssé alkalmazhatóak, és olyan lépéseket is tartalmaznak, amelyeket mai megítélés szerint információs szempontból vagy gazdaságilag nagyon nehéz, vagy akár lehetetlen végrehajtani (ilyen például a lakosok kényszer alatti áttelepítése).

A felkelések jelentette fenyegetés egy dinamikusan változó kihívást jelent, amire nincs egy megfelelő válasz. Taktikai szintre lebontva a kérdést, a felkelés számos területen jelent problémát, amit a fegyveres erők és a polgári hatóságok együttmüködésével kell megszüntetni. A regionális különbségek, a folyamatos alkalmazkodás ezért fontos szempontok a felkelésellenes müveletekben.

A harmadik szereplős felkelésellenes modell még a szakirodalomban is újdonság az elmélet újdonsága és a ténylegesen harmadik szereplősnek mondható felkelésellenes müveletek kis száma miatt, és így kevés a felhasználható szakmunka is. A modell ennek ellenére hatékonyan tudja megmutatni a napjainkban zajló felkelésellenes müveletek megváltozott jellegét. De a preklasszikus szakasz szerzőinek müvei is tartalmazhatnak fontos elméleti támpontokat, mivel az akkori beavatkozások államkudarchoz hasonló körülmények között történtek.

Az eddigi vizsgálatok alapján négy jelentős szempontot azonosítunk, amelyek egy modern felkelésellenes doktrína vizsgálatához fontosak. Az előző fejezetben vizsgált harmadik szereplős deficitek és a klasszikus szakasz szerzőinek tapasztalatait figyelembe véve az alábbi szempontok mentén vizsgáljuk a kortárs doktrínákat: 
1. politikai deficit menedzselése: a politikai célok elsődlegességének elismerése, beépítése a taktikai szintre

2. stratégiai deficit menedzselése: ${ }^{131}$ az aktuális felkelés sajátosságainak ismertetése és a megsegített állam hatóságaival való együttmüködés, illetve a civil-katonai együttmüködés kérdése

3. katonai deficit menedzselése:

- szervezeti rugalmasság előtérbe állítása

- koalíciós trend megfelelő feldolgozása

- a kultúra szerepének kiegyensúlyozott kezelése és a regionális sajátosságok beépítése

- a civil szervezetek által ellátott feladatok ideiglenes ellátására való felkészítés a konfliktusos övezetekben

4. információs deficit menedzselése: a megfelelő mérési rendszer és a hírszerzés változó jellegének beépítése, és a megváltozott információs környezet előnyeinek és hátrányainak ismertetése

\section{USA FM 3-24 Felkelésellenes müveletek}

2003-ban az amerikai hadseregnek nem volt megfelelő doktrínális háttere a kialakuló felkelés hatékony leküzdésére. Az amerikai erők kezdetben (részben a doktrínális alapok hiánya, részben a nem megfelelő tervezés miatt) nem voltak képesek megfelelően kezelni a kialakuló felkelést. 2004-ben az afganisztáni helyzet változása, valamint az iraki helyzet nagyarányú romlása miatt az amerikai hadsereg vezetése egy felkelésellenes doktrína kidolgozása mellett döntött. Ennek első eredménye a 3-07.22 Kézikönyv (Ideiglenes) (Field Manual Interim, FMI 3-07.22) 2004-es kiadása volt. Döntően taktikai megközelítéseket tartalmazott, nem teremtett meg egy átfogó megközelítést a felkelésellenes műveletek végrehajtására.

Ez nem jelenti azt, hogy nem voltak pozitív példák: a 3. páncélos lovasezred (3rd Armored Cavalry Regiment, 3rd ACR) Tall Afar-i fellépése 2005-ben, majd az egy évvel később Ramadiban végrehajtott felkelésellenes müveletek azt mutatták, hogy az alkalmazkodás a taktikai szinten megfelelő vezetés mellett látványos sikereket tud

\footnotetext{
${ }^{131}$ A vizsgált doktrínák a hadmüveleti szintre íródnak, ezért nincs hatásuk a stratégiai kérdésekre, ugyanakkor mindenképpen figyelembe kell venniük a realitásokat, máskülönben nem lehetnek relevánsak.
} 
eredményezni. Emellett a professzionális amerikai katonai médiában is jelentkeztek gyakorlati tapasztalattal rendelkező szerzők, akik az alkalmazott felkelésellenes megközelítés felülvizsgálatára tettek javaslatot civil és katonai oldalról egyaránt. Az FMI 3-07.22 doktrína felülvizsgálatára 2006-ban került sor, eredményeként született meg az FM 3-24 Felkelésellenes Müveletek.

Az FM 3-24 megalkotása összefonódott David Petraeus tábornok nevével. Az FM 3-24 az amerikai neoklasszikus felkelésellenes szakasz kései megnyilvánulásának tekinthető. Nagy vívmánya az volt, hogy nemcsak a hadseregre és a tengerészgyalogságra vonatkozott, hanem egy széleskörü felülvizsgálatot indított el a civilekkel, valamint a szövetséges országok felkelésellenes szerepvállalásával kapcsolatos kérdésekben. Az FM 3-24 nagymértékben támaszkodott a klasszikus teoretikusok munkáira, különösen Galula kapott benne kiemelt figyelmet. Megpróbálta a klasszikus szerzők munkáit a kortárs stratégiai realitások közé átültetve intézményi szintre emelni a lakosságközpontú felkelésellenes megközelítést. Ez a törekvés azért lehetett sikeres, mert az Irakban kialakult helyzet stabilizálására a politikai vezetés a stratégiaváltást látta egyetlen lehetőségnek, és támogatta a megvalósítását.

Az FM 3-24 számos területen hozzáigazította a klasszikusok elméleteit az aktuális nemzetközi környezethez. Ilyen az aktorok számának növekedése a hadszíntéren, és a civil szervekkel való együttmüködés problémái. A szociális hálózatvizsgálatok bevezetése, mint elemzési eszköz a felkelő csoportok vizsgálatára, szintén hasznosnak bizonyult. A klasszikusoknak azonban nem kellett városi központú, hálózati felépítésű, sokszor transznacionális jellegü felkelő csoportok ellen fellépniük. Ennek van egy megkerülhetetlen migrációs vonatkozása, mivel ma a városi lakosság aránya világszerte meghaladja a vidéki lakosságét. A klasszikusok ellenségképe a vidéki központú, szigorúan hierarchikus, lakossági mozgósításra épülő szervezet, kiterjedt árnyékkormányzási rendszerrel. A mai felkelésekben ezek a struktúrák sokszor hiányoznak. A felkelések városi megközelítése is szerény figyelmet kap a doktrínában. (Hoffman [2007] 75-77. o.)

Az FM 3-24 készítésénél fontos újdonságot jelentett, hogy nem csupán katonai forrásokra támaszkodtak az írásánál, hanem bevontak olyan civil aktorokat is, akik aktív szerepet játszottak felkelésellenes konfliktusokban.

Terjedelmi okok miatt nincs módunk az FM 3-24 részletesebb tárgyalására. Az alábbiakban az FM 3-24 által beindított legfontosabb doktrínális innovációval 
foglalkozunk: a NATO 3.4.4 Szövetséges Összhaderőnemi Publikációval (Allied Joint Publication, AJP).

\section{NATO 3.4.4 Szövetséges Összhaderőnemi Publikáció}

\section{Az irreguláris fenyegetés és a felkelés kapcsolata}

A doktrína komplex kihívásrendszerként határozza meg az irreguláris tevékenységnek ${ }^{132}$ nevezett kérdéskört. Az irreguláris tevékenység részeként terrorista és bűnözői csoportok összefoghatnak felkelőkkel a helyzet kihasználására. Az irreguláris kihívás határokon átnyúló is lehet, és akkor válik akuttá, amikor a résztvevő csoportok elleni fellépés a bünüldözés hagyományos keretei közt lehetetlenné válik. Ha ez bekövetkezik, káosz alakulhat ki, ami kedvező az irreguláris tevékenység számára, aminek részét képezheti a szubverzió is. (AJP-3.4.4 [2011] 2 - 15. - 2 - 17. o.)

Az irreguláris tevékenység kedvező táptalaj lehet a felkeléshez. Bár tünhet úgy, hogy a felkelök legitim tevékenységet végeznek, miközben elhatárolják magukat az irreguláris tevékenységtől, proxy csoportokon keresztül kapcsolódnak más irreguláris szereplőkhöz. ${ }^{133}$ A felkelés, mint irreguláris tevékenység, nem törvényes, azonban közös súlyponttal rendelkezik azokkal, akik a felkelésellenes műveleteket hajtják végre, ezért szüksége van a lakosság jóváhagyására és támogatására. (AJP-3.4.4 [2011] 2 - 17. o.)

A felkeléssel kapcsolatban a doktrína rögzíti az erőszak alkalmazásának céljait, elhúzódó voltát és a lakosság feletti irányítás megszerzésének fontosságát, valamint a napjainkban tapasztalható transznacionális jelleget. Feltételezhetően Galula munkájából merítve a dokumentum nagyobb teret szentel a felkelők magokainak vizsgálatára. ${ }^{134} \mathrm{~A}$ mozgatórugó a közös narratívára alapozott ideológia, amely identitást teremthet, és

${ }^{132}$ Az irreguláris tevékenység „, erő alkalmazása vagy azzal való fenyegetés irreguláris erők, csoportok vagy egyének által, sokszor ideológiai vagy bünelkövetési motivációval, azzal a céllal, hogy változást csikarjanak ki vagy akadályozzanak meg, kihívást intézve a fennálló kormányzattal és legitim hatalommal szemben." (AJP-3.4.4 [2011] 2 - 15. o.)

${ }^{133}$ Az irreguláris szereplők javuló képességei közé sorolja a dokumentum az alábbiakat: az információs technológia alkalmazását a megfelelö közönségek az arra szabott üzenettel, irreguláris stratégiák elsajátítását más szereplőktől, jelentős improvizációs képességet a fegyverzet terén, magas fokú szervezeti rugalmasságot stb. (AJP-3.4.4 [2011] 2 - $17-2$ - 19. o.)

${ }^{134}$ Identitás, vallás, gazdaság, korrupció, elnyomás, idegen kizsákmányolás vagy jelenlét, megszállás, a lakosság alapvető igényeinek ki nem elégítése a főbb lehetséges magokok. (AJP-3.4.4 [2011] 3 - 3 3 - 4. o.) 
amelyben sokszor a stratégia alapjai is jelen vannak. ${ }^{135}$ (AJP-3.4.4 [2011] 3-3. - 3-6. o.)

A felkelések fázisolása kapcsán a dokumentum a maoi megközelítést alkalmazza, hozzátéve, hogy a felkelések mozaik jellege és egyedi fejlődési irányai miatt a lineáris fejlődés nem mindenütt ismerhető fel, valamint lehetnek regionális különbségek, ezért nem alkalmazható minden felkelésre. (AJP-3.4.4 [2011] 3 - $11-3$ - 12. o.)

A doktrína hangsúlyt fektet arra, hogy bemutassa, a felkelő szervezetnek milyen kihívásokkal kell szembenézni a siker érdekében pénzügyi, infrastrukturális, emberi erőforrásbeli stb. téren. Kiemeli a jelentős improvizációs, kommunikációs és tanulási képességeket, amelyekről a felkelő csoportok bizonyságot tettek az utóbbi időszakban. (AJP-3.4.4 [2011] $3-14-3-15$. о.)

A doktrína vizsgálja a felkelés sebezhetőségét. A főbb sebezhető pontok:

- Biztonság: a titoktartás csökkentheti a felkelők műveleti szabadságát, a célok és elvek megjelenítésének hatékonyságát. Jelentős feszültség van a lakossági támogatás növelése és a biztonság fenntartása, valamint az ezzel kapcsolatos elkerülhetetlen szervezeti növekedés között.

- Decentralizáció: A hálózati felépítés jellege miatt lassítja az információáramlást.

- A felkelő narratíva inkonzisztenciája: Ha inkonzisztens a célok kommunikációja, akkor a lakosság bizalma csökkenhet a felkelőkben.

- Felkelő propaganda: Ha a felkelés konzisztensen dezinformációra alapozza a kommunikációját, megfelelő bizonyítékokkal alátámasztott kommunikációval alá lehet ásni.

- A bázisok létesítésének szükségessége: A helyszínek rossz vagy óvatlan megválasztása a felkelésellenes erő előnyére válik.

- A támogatástól való függés: Általában szükség van ilyen forrásokra a sikerhez azonban a logisztikai, kommunikációs és egyéb sebezhetőségeket okozhat.

- Gazdasági és pénzügyi gyengeség

- Belső megosztottság: Egy felkelő csoport egysége sosem teljes, ennek megfelelően, ha belső hatalmi harc tör ki, az a csoport moráljának csökkenéséhez fog vezetni. (AJP-3.4.4 [2011] 3 - 16-3-17. o.)

\footnotetext{
${ }^{135}$ A külső támogatás terén is széleskörü vizsgálati kört használ a dokumentum: az állami támogatástól kezdve az emigráns közösségek, menekültek, nem állami csoportok
} 


\section{Felkelésellenes müveletek}

A doktrína széles értelemben definiálja a felkelésellenes müveleteket. ${ }^{136}$ Minden olyan tevékenységet és aktort a felkelésellenes erők kategóriájába sorol, amelyek/akik részt vesznek a végrehajtásban (vagyis a civil ügynökségeket és hivatalokat, valamint a megsegített ország civil és fegyveres szerveit is ebbe a kategóriába sorolja). A rugalmas felfogás fontosságát, a kulturális megértés fontosságát, a felkelői oldal megértésének fontosságát, és a konfliktus politikai jellegének fontosságát hangsúlyozza. Fontosnak tartja a felkelések egyediségének szem elött tartását, célja a felkelők legyőzése és a magokok kezelése, amelyek eléréséhez politikailag motivált, hírszerzés vezette müveletekre van szükség (szükség esetén diplomáciai eszközöket igénybe véve a lehetséges transznacionális dimenzió kezelésére). A dokumentum azt is leszögezi, hogy a katonai győzelem önmagában elégtelen a felkelés legyőzésére, a fő cél a megsegített ország felkészítése a felkelés leverésére. A tervezésben fontos szerepet szán a stabilizációs müveleteknek. (AJP-3.4.4 [2011] 3-18-3-20. o.)

A tervezésnél a NATO-országok által meghatározott célok mellett a megsegített állam politikai célkitűzéseinek figyelembe vételére is felhívja a figyelmet a dokumentum. Az AJP-3.4.4 többfajta megközelítést ismer a felkelésekkel szembeni fellépésre, úgymint a közvetlen, a kiegyensúlyozott és az indirekt megközelítést. Ezeknek a megközelítéseknek az alkalmazhatósága nem kis mértékben függ a felkelés állapotától. A közvetlen megközelítést akkor tartja szükségesnek, ha nincs működőképes kormány. Ilyen esetben a biztonság megteremtése az elsődleges cél. A helyzet javulásával a kiegyensúlyozott megközelítésre kell váltani, ami azt jelenti, hogy a megsegített állam stratégiájával összhangban a NATO-erök a törvényes keretek betartásával politikai, katonai és fejlesztési tevékenységet végeznek. Ennek fontos része a felkelői narratíva hatékony támadása és diszkreditálása. Az indirekt megközelítés a politikai törekvéseket helyezi előtérbe. ${ }^{137}$ Ehhez az szükséges, hogy a megsegített ország politikai és biztonsági intézményrendszere képes legyen valamilyen szinten fellépni a felkelökkel szemben, és támogassa ezt a tevékenységet. (AJP-3.4.4 [2011] 4 7. o.)

\footnotetext{
136 „Politikai, gazdasági, szociális, katonai, bünüldözési, polgári és pszichológiai tevékenységek, melyek célja egy felkelés legyözése és alapvetö indokainak kezelése.” (AJP-3.4.4 [2011] 3 - 18. o.)

${ }^{137} \mathrm{Az}$ amerikai fogalomkörrel összehasonlítva az indirekt megközelítés ebben az összefüggésben inkább a FID-del hasonlítható össze.
} 
A katonai tervezésnél ${ }^{138}$ a megfelelő végcél meghatározása nemcsak katonai célok kitüzését jelenti, hanem az általános politikai és gazdasági helyzetben is azonosítani kell a megvalósítandó állapotokat. A tervezésnek fontos része a felkelésellenes műveletek sajátosságainak és a rendelkezésre álló erőforrások sajátosságainak maximális figyelembe vétele mellett a fellépés szakaszainak, ${ }^{139}$ valamint a kockázatoknak a meghatározása. A doktrína külön figyelmet szentel az idő-tér-erő hármasának sajátos kapcsolatára a felkelésellenes müveletekben. ${ }^{140}$ (AJP-3.4.4 [2011] $4-8-4-11$. o.)

A katonai erő célját az AJP-3.4.4 a lakosság védelmében és a felkelők semlegesítésében határozza meg, ami a megsegített ország támogatásával és a magokok orvoslásával elősegíti a politikai megoldást a konfliktussal kapcsolatban. A felkelők fegyveres erejének megsemmisítése nem tételes célja a felkelésellenes erőnek ebben a kontextusban, de része lehet a politikailag kibékíthetetlen felkelők elleni fegyveres fellépés. (AJP-3.4.4 [2011] 5 - 1. o.).

Tíz fontos tapasztalatot emel ki a korábbi felkelésellenes müveletek tapasztalataiból, amire alapozva a saját prioritásokat fogalmaz meg a dokumentum. Ezek:

1. a politika elsődlegessége (és egyértelmủen megfogalmazott politikai célok)

2. a lakosságért vívott küzdelem és nem a lakosság ellen

3. a legitimáció releváns

4. a hírszerzés a műveletek motorja

5. az erőfeszítés egységessége (koordinált kormányzati struktúra szükségessége)

6. a felkelők semlegesítése és elszigetelése a támogatóiktól

7. elhúzódó hadjáratra való felkészülés szükségessége

8. a törvényes kereteken belüli biztonság nyújtása létfontosságú

9. a feladatok átadása a helyi erőknek olyan gyorsan, ahogyan kivitelezhető

${ }^{138}$ Fontos, hogy a tervezést olyan víziónak kell megelőznie, amely a katonai és az információs müveleteket megfelelően integrálja. Fontos továbbá a jogi megfontolások alapos körüljárása, valamint a pszichológiai műveletek alkalmazáskörének meghatározása. (AJP-3.4.4 [2011] 4 - 12 - 4 -14. o.)

139 „A tevékenységek sorrendbe helyezése, mind az időben egymást követö, mind az egymással párhuzamos tevékenységeké, amelyek katonai müveletekhez és végül sikerhez vezetnek." (AJP-3.4.4 [2011] 4 -9. o.)

${ }^{140}$ Ennek a legfontosabb vetülete a tervezésre és végrehajtásra nézve, hogy a felkelésellenes erőnek meg kell választania, hogy milyen területeken, milyen ütemben, mekkora erővel akarnak haladni. A túlzottan optimista megközelítés a térben túl gyors elörehaladást eredményezhet, ami kifáraszthatja a felkelésellenes erőt, lerövidítve a rendelkezésére álló időt, politikai okokból, mivel az ilyen müveletek látványos kudarcokhoz vezethetnek. Hasonlóképpen expedíciós jellegủ műveleteknél az idő és az erő kapcsolata a logisztikai realitásokban gyökerezik: egy jelentős expedíciós erő mozgósításához és hadszíntérre szállitásához sok idő szükséges. (AJP-3.4.4 [2011] 4 - 10. o.) 
10. gyorsan kell tanulni és alkalmazkodni. (AJP-3.4.4 [2011] 3 - 20. o.)

A felsorolt szempontok a klasszikus felkelésellenes irodalom számos kiemelten kezelt tanát adják vissza. A politikai célok elsődlegessége terén a dokumentum például leszögezi, hogy: „A felkelésellenes hadjárat megindítása elött egyértelmüen megfogalmazott és elérhetö politikai célokat kell kitüzni. A politikai cél sikeres biztositása érdekében több köztes célt is ki kell tüzni, közzé kell tenni és ismertetni kell a vendéglátó állam lakosságával a kormányuk szándékát.” (AJP-3.4.4 [2011] 3 - 20. o.) A katonai tervezésnek és fellépésnek minden szempontból összhangban kell lennie a politikai célokkal, de a sikerhez a politikai akarat megléte nélkülözhetetlen. Hozzáteszi: „A politikai akaratot a felkelésellenes müveletekben a felkelök a liberális demokráciák Achilles-sarkának tekintik. A felkelésellenes fellépések általában azért vallottak kudarcot, mert nem voltak képesek a politikai akaratot fenntartani az elhúzódó hadjáratokban. A felkelés és a felkelésellenes müveletek nem mások, mint folyamatos „politikai akaratok vetélkedései” mind otthon, mind a müveleti területen.” (AJP-3.4.4 [2011] 3 - 20. o.)

A doktrína szerint a gyakorlatban ez azt jelenti, hogy a felkelésellenes erőnek a szövetségi politika nehézségei miatt olykor homályos politikai iránymutatás mellett kell boldogulni, és gyenge állam esetében a célok nehezen megvalósíthatók. (AJP-3.4.4 [2011] 5 - 2. o.)

A második kitétel, a „lakosságért vívott küzdelem és nem a lakosság ellen” kapcsán egyértelmű harmadik szereplős értékrendet fektet le a dokumentum. A lakosság bizalmát a felkelésellenes erőknek a dokumentum szerint a megsegített állam hatóságai felé kell irányítani, aminek egyik módja az ellenséges kommunikáció akadályozása, a másik a saját aktív, egységes narratívába illeszkedő kommunikáció terjesztése. Ehhez szorosan kapcsolódik a legitimáció kérdése. A legitimáció forrása:

- „a lakosságnak a vendéglátó állam legitimitásáról kialakitott percepciója, beleértve a biztonsági eröiket is

- a szövetséges biztonsági erők legitimációjáról kialakitott kép a nemzetközi hatóságok, a vendéglátó állam és a hozzájáruló nemzetek részéről.” (AJP-3.4.4 [2011] 3 - 21. о.)

Vagyis a három korábban bevezetett legitimációs körből mindet figyelembe veszi a doktrína a kérdés vizsgálatánál. A legitimitás indikátorai közé sorolja a dokumentum például a megsegített állam intézményeinek széleskörü társadalmi elfogadását és a lakosság politikai reprezentációjának széleskörü elfogadását. (AJP-3.4.4 [2011] 3 - 21 - 
3 - 22. o.) A nemzetközi környezetbeli legitimációval kapcsolatban is fontos megállapításokat tesz a dokumentum:

- „Legyen nemzetközi támogatás vagy legalább semlegesség.

- Diplomáciai akciók végrehajtása a vendéglátó ország környezetében lévö államok megnyerésére és befolyásolására. Törekedni kell elmagyarázni a lakosságnak és a kapcsolódó kormányoknak a szövetséges erök beavatkozásának célját. Ez segithet a vendéglátó állam határainak biztositásánál, ami alapvetö fontosságú, amikor a felkelö külsö támogatásának felszámolására kerül a sor” (AJP-3.4.4 [2011] 3 - 22. o.)

A doktrína hozzáteszi, hogy a konfliktustermináció terén figyelembe kell venni a beavatkozó államok közvéleményét is, mivel az erők kivonása a beavatkozás után a szövetség kohéziójának károsodásához, a felkelés sikerkommunikációjához, illetve a képességek aláaknázáshoz is vezethet. (AJP-3.4.4 [2011] 3 -22. o.)

A dokumentum kitér arra, hogy a fizikai terep birtoklásának a sürün lakott területeken nagy jelentősége van, mivel a felkelők igyekeznek a lakosság soraiba beolvadva szabotálni a felkelésellenes erő törekvéseit. A civil veszteségek miatt az ilyen müveleteknél mindig megfontoltnak kell lenni. (AJP-3.4.4 [2011] 5 - 2-5 - 3. o.)

A hírszerzés ${ }^{141}$ alapvető fontosságú a dokumentum szerint, amihez az érintett lakossággal való szoros együttmüködés, ${ }^{142}$ illetve a lakosság ismerete szükséges. Az ellenséges struktúrák és fellépés elemzése és előrejelzése mellett számos más feladatot is meghatároz a hírszerzés számára. Ezek közé tartozik a megsegített állam hírszerzési infrastruktúrájának kiépítése, megerősítése és az azzal való hatékony együttműködés. ${ }^{143}$ $\mathrm{Az}$ információs tevékenységgel is koordinálni kell a hírszerzési tevékenységet. A hírszerzésnek alapvető nyelvi és kulturális szakértelem biztosítására van szüksége, amit a művelet megkezdése előtt kell biztosítani. (AJP-3.4.4 [2011] $3-22-3-23$. o.) A

\footnotetext{
${ }^{141}$ Kitsonhoz hasonlóan a dokumentum később leszögezi, hogy „, A hatékony hírszerzés létfontosságú a hatékony müveletekhez. Cserébe a hatékony müveletek általában olyan információkat eredményeznek, amelyek azonnali cselekvést igényelnek, megerösitett információkat, amelyek azonnal hasznosak, konkrét és hasznos információkat, amelyek elég jók ahhoz, hogy müveleteket inditsanak miattuk. Ehhez hasonlóan a nem hatékony vagy pontatlan hírszerzés általában nem hatékony müveleteket eredményez, amelyek sokszor nem megfelelö vagy negativ eredményekkel zárulnak." (AJP-3.4.4 [2011] 4 - 2. o.)

${ }^{142}$ Erre azért is van szükség, mivel a felkelés mozaik jellege miatt a hadsereg információ gyüjtő és fogyasztó egyben. A doktrína azt is megállapítja, hogy a konvencionális müveletek felülről lefelé haladó információáramlási modelljével szemben a felkelésellenes műveletekben pontosan fordított irányban kell áramlani az információknak. (AJP-3.4.4 [2011] 4 - 2. o.)

${ }^{143}$ A közvetlen feladatok közé tartozik: a felkelés stratégiájának meghatározása, a felkelő hadjáratterv elemzése, a felkelö tevékenység modellezése és az ezekhez a folyamatokhoz szükséges együttmúködés biztosítása a szövetségesekkel. (AJP-3.4.4 [2011] $4-2-4$-4. o.)
} 
hírszerzés másik fontos feladata, hogy felmérje a vendéglátó állam potenciális gyengeségeit, és ezzel járuljon hozzá azok felszámolásához. (AJP-3.4.4 [2011] 5 - 2. o.)

Az erőfeszítés egységessége kapcsán a doktrína a koalíciós fellépés sajátosságait veszi számba. A középpontba a „közös problémafelfogáson alapuló felkelésellenes stratégia kifejlesztése” és a vendéglátó állammal koordináltan végrehajtott fellépés kerül.

A felkelők semlegesítése és elszigetelése kapcsán fizikai, gazdasági és pszichológiai elszigetelést szorgalmaz, valamint a magokok felszámolását. A fizikai elszigetelés katonai eszközöket igényel, a többi területen polgári szervekkel kell együttműködni. A katonai erő lakosságirányításban való részvétele kapcsán a kiegyensúlyozott alkalmazására hívja fel a figyelmet, mivel a túl szigorú korlátozások negatív politikai következményekkel járhatnak. A magokok felszámolásával kapcsolatban gazdasági, szociális és politikai reformok támogatását, amnesztiaprogram kidolgozását, lakossági együttmüködés elősegítését, valamint a felkelők diszkreditálását és demoralizálást javasolja. (AJP-3.4.4 [2011] 3 - 23 - 3-25. o.)

A konfliktus elhúzódó jellegével kapcsolatban arra hívja fel a figyelmet, hogy sokba kerül, jelentős erőforrásokat igényel. (AJP-3.4.4 [2011] 3 - 25. o.)

A törvényes keretek közötti felkelésellenes műveleteket katonai erök végzik a vitatott területeken, ahol erős a felkelői jelenlét és a civil ügynökségek és hivatalok nem képesek önállóan müködni. A fegyveres erőknek kell a civil szervek által biztosított kapacitásokat emulálni azért, hogy az erőszak mértékét a lehető leggyorsabban csökkentsék. A megsegített ország bünüldöző szerveinek a támogatása vagy szükség esetén felépítése is fontos részét képezi ennek a folyamatnak. Katonai eröt csak kivételes esetekben szabad bünüldözési célokra felhasználni. A cél mindig a törvényes rend erősítése. (AJP-3.4.4 [2011] 3 - 25 - 3-26. o.)

A helyi biztonsági erőknek való feladatátadás a kivonulási stratégia része a harmadik szereplős felkelésellenes müveletekben. A gyenge államokban ez nehéz és hosszabb folyamat. (AJP-3.4.4 [2011] 3 - 26. o.)

A tanulás és alkalmazkodás terén a felkelői oldal a gyorsabb, az ő alkalmazkodó képessége jobb. Amennyiben a felkelésellenes erő nem alkalmazkodik az ott történt változásokhoz, rontja a saját lehetőségeit. De a felkelésellenes erőnek nemcsak a felkelői oldalon történt változásokat kell folyamatosan nyomon követni. Arra is fel kell készülnie, hogy a politikai vezetés támaszt vele szemben új igényeket. (AJP-3.4.4 [2011] 3 - 26-3-27. o.) 


\section{Mérési szempontok}

Az AJP-3.4.4 ezen a téren elég szűkszavú. A hírszerzésre vonatkozó részben az alábbi passzus foglalkozik a kérdéssel: „A NATO-eröknek a felkelésellenes müveletekben az anyagi alapú indikátorokra kevésbé kell támaszkodniuk, mint a szubjektív, de rendszerszintü elemzésekre. A sokszor azonosithatatlan és a környezetbe beleolvadó technikai felszerelés nem ad megfelelö jelzést az ellenség szándékairól. A felkelök elkötelezettségét és a céljait kell megérteni. A pontos elemzés nehéz a komplex emberi környezetben, föleg a megfelelö információk kiválasztásának nehézsége miatt. Ráadásul a nyelv kritikus tényezö a hírszerzési feladatoknál.” (AJP-3.4.4 [2011] 5 - 3 5 - 4. о.)

A megsegített ország politikai-katonai és egyéb tevékenységére vonatkozó adatok nem szerepelnek a mérésre érdemes szempontok között, ami a konfliktus fontos területének elhanyagolását jelenti (viszont érthető, hiszen a megsegített ország feltételezhető politikai érzékenysége miatt ennek a szempontnak doktrínába foglalása és végrehajtása valóban nehézségekbe ütközhetne).

A mérési szempontok politikailag relevánssá tétele a másik fontos tényező, amivel a doktrína nem foglalkozik, holott ez hasznos lehetne a politikai problémák megoldásánál (elsősorban a normatív differencia csökkentésében).

\section{Információs tevékenység}

$\mathrm{Az}$ információs dominancia megszerzése ${ }^{144}$ az AJP-3.4.4 egy fontos eleme. A percepciók fontosságát hangsúlyozza a tényekkel szemben, ezzel próbálja védeni a lakosság információs környezetét és befolyásolhatóságát a felkelői kommunikáció torzító hatásától. A doktrína aktív fellépésre ösztönzi a felkelésellenes müveletekben résztvevő erőket, azon az alapon, hogy a passzivitás a felkelői oldalnak biztosítja a kezdeményezést ezen a fontos területen. A kezdeményezés itt a pontosan alátámasztott tények kommunikálása a szélesebb közvélemény felé. A doktrína Galulához hasonlóan abból indul ki, hogy a felkelői oldalnak nem kell ragaszkodnia a tényekhez, ennek következtében jóval rugalmasabb kommunikációra képes, mint a felkelésellenes oldal.

\footnotetext{
${ }^{144}$ A hadsereg ebben a saját pszichológiai műveleti kapacitásainak alkalmazásával tud részt venni. (AJP3.4.4 [2011] 5 - 5. o.)
} 
Emiatt is elkerülhetetlen, hogy időnként nem a teljes valóság ismeretében kell reagálni a felkelői propagandára, de ilyenkor is pontosságra kell törekedni.

Az alapvető prioritásokat a korábbiakkal összhangban határozza meg a dokumentum:

- a vendéglátó állam legitimációjával és képességeivel kapcsolatos pozitív kép és vélemény kialakítása ${ }^{145}$

- helyi és nemzetközi támogatás megszerzése és biztosítása a felkelésellenes műveletek végrehajtásához

- a felkelői erőszak publikálása és a felkelői propaganda csúsztatásainak tudatosítása a lakosságban

- a felkelöi propaganda diszkreditálása

- pozitív narratíva, ami hozzájárul a harmadik szereplős erők jelenlétének biztosításához, amíg szükséges (AJP-3.4.4 [2011] 5 - 4 - 5 - 5. o.)

A felkelésellenes erő információs fellépése a dokumentum szerint akkor sikeres, ha képes aláásni a felkelői oldal legitimációját a célközönsége(i) előtt. ${ }^{146}$ Ennek érdekében minden jelentős katonai lépést megfelelő kommunikációs lépésnek kell kísérnie. (AJP-3.4.4 [2011] 5 - 5. o.)

\section{Felkelésellenes múveletek végrehajtása}

Alapvető katonai feladatok a doktrína szerint:

1. A lakosság biztosítása: A cél a tisztelet elérése, az ellenséges irányítás és befolyás megszüntetése és a lakosság kormány mellé állítása. A lakosság biztosítása segíti a gazdasági tevékenységet és a hosszabb távú igazgatási reformokat. A bizalom megszerzésével a felkelők egyik alapvető stratégiája hiúsul meg. (AJP-3.4.4 [2011] 5 - 12. o.)

2. A felkelők elszigetelése: A felkelők elszigetelése a bázistól és a külső támogatóktól való elszigetelést jelent. Műveleti szabadságot ad a felkelésellenes erőnek. (Regionális vonatkozásban a külső támogatás és a menedék megszüntetését jelenti.) A doktrína szerint ebbe beletartozik a felkelő szervezet

\footnotetext{
${ }^{145}$ Vagyis: nem a külföldi erők népszerüsítése a cél. Ez fontos, és sokszor nem elég hangsúlyos szempont. ${ }^{146}$ Ennek megvalósítására megfelelő ellenok vagy ellenokok létrehozását javasolja a doktrína. (AJP-3.4.4 [2011] 5 -9. o.)
} 
belső (utánpótlást biztosító és egyéb fontos feladatokat ellátó) struktúráinak támadása is. (AJP-3.4.4 [2011] 5 - $12-5$ - 13. o.)

3. A felkelő szervezet fegyveres szárnyának semlegesítése: Olyan tevékenység, ami kisebb mértékben fizikai, nagyobb mértékben pszichológiai jellegü, gyakran a helyi lakosság aktív részvételével történik. Célja a felkelői erőszak alkalmazásának megszüntetése. Erre több lehetőséget vázol fel, pl. a felkelés megosztása és részletekben történő felszámolása, konvencionális támadás kikényszerítése A doktrína az olajfolt stratégiát javasolja a felkelök kiszorítására a lakott területekről, csökkentve ezzel a müveleti szabadságukat. Amennyiben ez sikerrel jár, a harmadik szereplős erőknek mindent meg kell tenniük, hogy a megsegített ország biztonsági erőit hatékonnyá tegyék, és úgy adhassák át nekik a feladatokat, hogy ne valljanak kudarcot. (AJP-3.4.4 [2011] 5 - 12 - 5 - 13. o.)

A doktrína ismertet taktikákat - átkutató müveletek, lakossági kontroll stb. -, de nem megy bele a részletekbe.

Arra figyelmeztet, amire a klasszikus szakasz szerzői: nem szabad eröltetni a vitatott területek feletti irányítás megszerzését (tipikus jele ennek a felkelésellenes erők nappali dominanciája a felkelő erők éjszakai domináns szerepével szemben). A müveletek lezárása után a diplomáciai dimenziónak jut fontos szerep a nemzeti megbékélés elősegítésében, a civil aktoroknak pedig a helyreállításban és a fejlesztésben. (AJP-3.4.4 [2011] 5 - 25 - 5-26. o.)

\section{NATO formula: megtisztítani, megtartani, felépíteni}

A formula mint müfaj nem újdonság, Thompson és Galula is megfogalmazta a maga formuláit. Ez amerikai hatást mutat, az FM 3-24 ugyanezt a formulát alkalmazza $^{147}$ a három fö felkelésellenes megközelítés egyikének megnevezésére. (FM 3-24 [2006] 5 - 18. o.) A két formula ennek megfelelően jelentős átfedést mutat.

Az AJP-3.4.4 szerint „A megtisztítani, megtartani, felépiteni [formula] civilkatonai fellépést jelent a felkelésellenes müveletekben, ami összefogja a NATO-t, a vendéglátó államot és a civil aktorokat. A megtisztítani, megtartani, felépiteni [formula]

147 „A megtisztítani-megtartani-felépíteni müveleteket konkrét, kiemelt fontosságú területeken kell végrehajtani, ahol nyilt felkelöi tevékenység észlelhetö. Céljai:

- biztonságos fizikai és pszichológiai tér létrehozása

- $\quad$ szilárd kormányzati kontroll kialakitása a lakosság és a terület felett

- a lakosság támogatásának megszerzése.” (FM 3-24 [2006] 5 - 18. o.) 
része az offenziv, defenziv, stabilizációs és kapacitásépitő tevékenységnek. A megtisztítani, megtartani, felépiteni [formulát] a müveleti környezet alapos ismerete kell, hogy kisérje.” (AJP-3.4.4 [2011] 5 - 13. o.) A megközelítés célja, hogy a felkelök kiszorításával stabil irányítást hozzon létre terület és lakossága felett, lehetővé téve a megsegített ország kormányzati és fejlesztési tevékenységét, és megakadályozva a felkelők ellentevékenységét. (AJP-3.4.4 [2011] 5 - 14. o.)

A hatékonyság megállapítására az AJP-3.4.4 számos ismérvet ad, mérési javaslatokkal azonban nem él. Ezek:

- a lakosság hatékony védelme a felkelő pszichológiai műveleteitől

- a végrehajtandó reformokhoz szükséges állapotok megteremtése

- a lakosság és a kulcsfontosságú infrastruktúra védelme

- a megsegített állam biztonsági erőinek kiképzése és szerepvállalásának biztosítása

- a megsegített állam biztonsági erői és más kormányzati intézményei számára lehetőség adása a biztonság megteremtésében

- a magokok megszüntetésének biztosítása

- a menekültek elhelyezése és visszatérésük segítése ${ }^{148}$

- a helyi közösség és a helyi erőforrások bevonása a rend fenntartásába és az újjáépítésébe

- a felkelök támogatásának semlegesítése a lakossági támogatás felkelésellenes erő számára történő biztosításával (AJP-3.4.4 [2011] 5-14 - 5-15. o.)

A tevékenység négy fázisra osztható: felkészülési fázis, megtisztítási fázis, megtartási fázis és építési fázis. Minden fázis a civil és katonai szervek együttmüködésének sajátos elegye. A katonai elem szerepe az idő előrehaladtával csökken, és a civil szerepvállalás válik elsődlegessé. A felkészülési fázisban kell meghatározni az alapvető célokat és feladatokat. A megtisztítási fázisban kerül sor az offenzív katonai müveletekre, a cél a felkelök fegyveres csoportjainak kiszorítása vagy megsemmisítése az adott területről, illetve a felkelők támogatóinak kiszorítása az állami intézményekből. A megtartási fázisban a defenzív müveletek dominálnak, a tranzíció megindul a megsegített ország biztonsági erőinek irányába. Ezzel egyidejüleg megkezdődik az alapellátás helyreállítása és a felkelő szervezet nem fegyveres részének

\footnotetext{
${ }^{148}$ Itt a civil szervezetek szerepe kifejezetten fontos, föleg az UNHCR-t emeli ki a dokumentum.
} 
felszámolása. A felépítési fázisban a stabilizációs műveleteké az elsőbbség, a helyi intézmények helyreállítására kell összpontosítani. (AJP-3.4.4 [2011] 5 - 15 - 5 - 17. o.)

A legfontosabb lépés az irányítás átadása a megsegített állam biztonsági és egyéb polgári szerveinek. Ezt a tranzíciós folyamatot a doktrína szerint jól mérhető feltételekhez kell kötni (ehhez ajánlásokat azonban nem tesz). Miután egy területen lezárult a folyamat, hozzá lehet kezdeni egy másikon - az olajfolt stratégia szellemében. (AJP-3.4.4 [2011] 5 - 17. о.)

\section{A biztonsági szektor reformja}

A megsegített ország biztonsági szektorának a megsegített állam által is fenntartható reformja alapvető fontosságú a harmadik szereplős felkelésellenes müvelet sikeréhez. Az AJP-3.4.4 teret enged a kérdés elemzésére. A reformnak átfogónak kell lennie, vagyis nem egyszerüen a rendőri és katonai erők reformjáról van szó, hanem a szélesebb igazságszolgáltatási rendszer és a büntetés-végrehajtás ${ }^{149}$ kiépítését is jelenti. A dokumentum fontosnak tartja leszögezni, hogy a nyugati minták alkalmazása ilyen helyzetben sokszor nem célravezető. (AJP-3.4.4 [2011] 4 - 13. o.)

A folyamat elkerülhetetlen részét képezi a fegyveres csoportok lefegyverzése, demobilizációja és reintegrációja a társadalomba. Ehhez szükséges a megbékéléshez vezető lépések és a politikai helyzet alapos ismerete, valamint szoros együttmüködés a helyi biztonsági erőkkel. ${ }^{150}$ (AJP-3.4.4 [2011] 4 - 13 - 4 - 14. o.) A folyamat sikere fontos, mivel azt mutathatja a felkelöknek, hogy érdemes abbahagyni a fegyveres harcot. Csak olyan folyamat végrehajtását látja kivitelezhetőnek a dokumentum, ami megfelelően van felépítve és finanszírozva, és minimalizálja a kudarc lehetőségét. (AJP3.4.4 [2011] 5 - 25. о.)

A biztonsági erők támogatásának részeként a harmadik szereplős erőknek - a megsegített állam biztonsági erőinek állapotától függően - részt kell venniük a szervezésben, a kiképzésben, a felszerelésben, az infrastrukturális lehetőségek javításában, valamint tanácsadó és támogató tevékenységet kell folytatniuk. Egy

\footnotetext{
${ }^{149}$ Ennek nagy szerepe van, mivel a nem megfelelően működő büntetés-végrehajtásban a börtönök toborzó, rosszabb esetben kiképző helyekké válhatnak, és az esetlegesen elkövetett túlkapások nyilvánosságra kerülése ronthatja a nemzetközi részvétel megítélését a koalíciós országokban.

${ }^{150}$ Ez nemcsak anyagi támogatást és képzést jelent, hanem azt is, hogy a harmadik szereplős fegyveres erőknek mindent el kell követniük annak érdekében, hogy a megsegített ország igazságszolgáltatási rendszerébe bekerült feltételezett felkelökkel kapcsolatos minden releváns információ (felszerelés, bizonyíték stb.) eljusson a hatóságokhoz. (AJP-3.4.4 [2011] $4-14-4-15$. o.)
} 
fejlesztési folyamatot igyekszik ezzel végigvinni a doktrína a források tervezésétől és a biztonsági erők kialakításától kezdve egészen a tranzícióig. ${ }^{151}$ (AJP-3.4.4 [2011] 5 - 22 $-5-23$. o.)

\section{Paradoxonok a felkelésellenes müveletekben}

Az AJP-3.4.4 nyolc paradoxont sorol fel az erő alkalmazásának potenciális veszélyeivel kapcsolatban: ${ }^{152}$

1.,,Minél jobban véded az eröidet, annál kevésbé vagy biztonságban.” - Meg kell találni az egyensúlyt az erők védelme és a feladat végrehajtása között. Nem szabad a felkelésellenes erőnek elszigetelni magát a megvédendő lakosságtól.

2.,,Minél több eröt alkalmazol, annál kevésbé lehet hatékony.” - Az erő alkalmazásának hatásait sokszor nem lehet előre látni, jelentős a tévedés esélye, főleg városi környezetben.

3.,,Minél sikeresebb egy felkelésellenes müvelet, annál kevesebb eröt lehet alkalmazni, és annál jelentösebb kockázatot kell vállalni." - Ez az előző pont kiegészítése. A felkelésellenes erőnek a nemzetközi jogi szabályozással összhangban változtatni kell az erőszak alkalmazásának keretein, a katonai helyett a rendőri tevékenységnek kell nagyobb hangsúlyt kapnia. (AJP-3.4.4 [2011] 5 - 10. o.)

4.,,Ha egy taktika müködik ma, nem biztos, hogy müködik a következö napokban; ha müködik egy adott területen, nem biztos, hogy egy másik területen is müködni fog. ”A felkelők általában hatékony kommunikációt folytatnak, és ezáltal képesek gyorsan alkalmazkodni a változásokhoz. Minél hatékonyabb egy taktika, annál gyorsabban válik idejét múlttá. Gyorsabban kell alkalmazkodni az ellenségnél, amihez szükséges a közös doktrína és taktikák. Nincsenek kész válaszok, a parancsnokoknak mindenre oda kell figyelni. (AJP-3.4.4 [2011] 5 - $10-5$ - 11. o.)

5.,,A taktikai siker önmagában semmit nem garantál.” A katonai müveletek önmagukban elégtelenek a felkelésellenes erő sikeréhez, a felkelök viszont akkor is elérhetik a stratégiai céljaikat, ha soha nem győznek. A taktikai célokat a saját és a vendéglátó állam stratégiai és műveleti céljaihoz kell igazítani.

\footnotetext{
151 Tanácsadói, mentorálási és egyéb képzési feladatok végzése. (AJP-3.4.4 [2011] 5 - 24 - 5 - 25. o.)

${ }^{152}$ Az FM 3-24 hatása az AJP-3.4.4-re egyértelműen kimutatható. Az FM 3-24 kilenc paradoxont tartalmaz. (FM 3-24 [2006] 1 - 26 - 1 - 28. o.) Az egyetlen, amit az AJP-3.4.4 nem vett át így szól: , Sok fontos döntést nem a tábornokok hoznak meg. ” Az amerikai doktrína itt a taktikai szintü vezetés szerepének fontosságáról beszél. (FM 3-24 [2006] 1 -28. o.)
} 
6.,,A tétlenség lehet legjobb reakció." - A felkelők sokszor a felkelésellenes erő túlreagálására számítva hajtanak végre akciókat. Ha az elemzések azt mutatják, hogy a negatív hatás nagyobb lesz, mint a pozitív, akkor a tétlenség a legmegfelelőbb válasz.

7.,,A felkelésellenes erö legjobb fegyverei közül néhány nem lö.” - A legitimáció biztosítása a vendéglátó országnak és a lakosság bizalmának megnyerése a legsikeresebb eljárás, és ezekhez nem kell felkelöket ölni. A felkelés állapotától függ, hogy katonai tevékenységre vagy a stabilizációs és helyreállítási törekvések támogatására van szükség.

8.,,A vendéglátó állam valamilyen elfogadható tevékenysége sokszor jobb, mint a külső erő által jól végrehajtott akció." - A vendéglátó állam viseli a felelősséget, ehhez szükség van a képességei javítására. Bár nehézkesnek tünik, hosszú távon a helyi végrehajtás előnyöket rejt magában. Megfelelő vezetés kialakítására van szükség, ezt segíti a NATO. Minél tovább tart a folyamat, annál nehezebb fenntartani a résztvevő államok politikai támogatását. (AJP-3.4.4 [2011] 5 - 11. o.)

\section{Politikai deficit}

Az AJP-3.4.4 egy átfogó megközelítést igyekszik megvalósítani. ${ }^{153}$ A doktrína megfogalmazásában: „A felkelés és a felkelésellenes müveletek nagymértékben különböznek, mégsem lehet öket elszigetelten vizsgálni; a felkelésellenes fellépés nem hagyhatja figyelmen kívül az irreguláris tevékenység hatásait és destabilizáló következményeit. A felkelö célja a politikai változás rákényszeritése a hatalmon lévőkre, míg a felkelésellenes erők célja, hogy a felkelök tevékenységét és a kapcsolódó irreguláris tevékenységet kordában tartsák, erösitve a vendéglátó állam kormányának legitimációját." (AJP-3.4.4 [2011] 1 - 3. o. $)^{154}$

${ }^{153}$ Érdekesség, hogy a doktrína az „emberi biztonság” koncepciót is alkalmazza. A dokumentum a biztonságot az alábbi módon definiálja: „, A biztonságot a jogtalan üldöztetéstől, hiánytól és félelemtől való mentesség, megfelelö ellátás az alapvető árucikkekböl az emberi élet fenntartására, szélesebb környezeti biztonság, a magántulajdon, a közjavak és kulturális értékek védelme jellemzi. Annak a képessége, hogy az egyén ezekkel szemben mennyire tud védekezni, létfontosságú képessége és funkciója a stabil államnak. A megtermelt javak piacra juttatásának, a gyerekek iskolába juttatásának és a szabad helyváltoztatásnak a képtelensége közvetlen hatással lesznek a lakosság bizalmára. Ezek a koncepciók nem abszolútak - a percepciók számítanak. A biztonságot le lehet bontani humán biztonságra, személyes biztonságra, nemzetbiztonságra és fizikai biztonságra." (AJP3.4.4 [2011] 2-2. o.)

${ }^{154}$ A dokumentum a katonai kiadványokban sokszor használatos fejezet-oldalszám megjelölést alkalmazza. A disszertációban másutt alkalmazott -tól -ig hasonló megjelenése miatt a doktrínáknál a fejezet és az oldalszám megkülönböztetés céljából szét lettek húzva. 
Ennek jegyében a dokumentum már a bevezetőben elismeri, hogy a felkelők számára a politikai szempontok sokkal nagyobb súlyúak, mint a katonaiak a lakosság szimpátiájának megszerzésében, ezért támogatni kell a politikai megoldást. Azért is fontos ez, mert sok segítő civil szervezet semleges, és nem kíván részt venni magában a konfliktusban (a felkelö szemszögéböl természetesen nem semleges). Ez a dilemma a felkelő számára lehetőséget jelent, amit megpróbálhat kiaknázni. Ezért a fellépés egységessége fontos. (AJP-3.4.4 [2011] 1 - 3. o.) Ennek jegyében leszögezi: „A felkelésellenes hadjáratok sikere nem egyszerüen a koherens katonai erö alkalmazása az ellenséggel szemben, hanem sok egyéb tényezö befolyásolja, (...) Ezért létfontosságú, hogy a lehetöség és a veszély felismerése érdekében a parancsnok megértse a kontextust, amelyben a katonai erö alkalmazásra kerül, és a hadjárat jellegét, amelyben részt vesz. Csak így képes a parancsnok a helyzetet az elönyére megváltoztatni, tanulni, alkalmazkodni és számítani a hadjárat előrehaladtával.” (AJP-3.4.4 [2011] 1 - 4. o.)

Az átfogó megközelítésnek része a nemzetközi dimenzió figyelembe vétele: a stratégiai-politikai szinten bizalom és kölcsönös megértés létesítése a nemzetközi aktorok között, a hatékony együttmüködés a helyi erőkkel és más nemzetközi aktorokkal a müveletek végrehajtásában és a civil-katonai együttmüködés. Ennek része, hogy kooperatív kultúrát kell megvalósítani, növelni kell az ügynökségi, a kormányközi és a nemzetközi szervezetekkel való együttmüködést. (AJP-3.4.4 [2011] $1-5-1$ - 6 . o.)

A NATO doktrínában, szövetségi rendszer lévén, megkerülhetetlen a koalíciós haderőre vonatkozó kérdések tárgyalása. Az AJP-3.4.4 felhívja a figyelmet ezeknek az erőknek az eltérő hátterére és képességeire, és ami még fontosabb, leszögezi: az erőket küldő államok sokszor a saját nemzeti érdekeiket fogják követni, így korlátozhatják a kiküldött erők bevethetőségét. (AJP-3.4.4 [2011] 2-9. o.)

Közvetve tárgyalja a normatív különbség kérdését is a veszteségek kapcsán. A jelképes anyagi vagy emberi veszteségek is csökkenthetik a politikai akaratot, és ezt a felkelök igyekeznek kihasználni. Felhívja a figyelmet arra, hogy fokozottan ügyelni kell az öngyilkos merényletek, az IED-k és a nagy hatótávolságú fegyverek alkalmazására. Az ilyen akcióknak jelentős járulékos veszteségei lehetnek, ami növelheti a normatív különbséget. A doktrína szerint az erők védelmének folyamatosan napirenden kell lenni, a gyakorlati végrehajtás azonban nem válhat a müveletek kárára (elszigeteltség, felesleges küldetések erőltetése stb.). (AJP-3.4.4 [2011] 5 - 7. o.) 


\section{Stratégiai deficit}

Az AJP-3.4.4 feltételezhetően az aktuális kihívások miatt nagy súlyt helyez a gyenge és instabil államok kérdésének vizsgálatára. ${ }^{155}$ Ennek jegyében három fő forrást különböztet meg: a biztonság hiányát, a gyenge kormányzást és a törvényesség hiányát, valamint az alulfejlettséget. Ezekből egynek a megléte feltételezi a többi viszonylag gyors megjelenését. A folyamatot nemcsak az adott konfliktusos területre szükíti: a szétesés folyamatának helyi, regionális és globális hatásai is lehetnek, ami fokozatosan terjed kifelé, és a biztonsági helyzet változásában, gazdasági hanyatlásban stb. jelentkezik, majd átcsap menekültkérdésbe bűnözésbe, a kormányzatmentes területek problémájába. (AJP-3.4.4 [2011] 2 - 3. o.)

A politikai környezet ${ }^{156}$ vizsgálatára is vállalkozik a dokumentum. Leszögezi, hogy „A politikai felügyelet és beavatkozás a katonai ügyekbe valóság, ami azt jelenti, hogy gyakorlatilag minden katonai tevékenység a támogatók és az ellenséges csoportok folyamatos vizsgálódásának van kitéve. A döntések és cselekedetek ritkán szoritkoznak csak egy szintjére a katonai fellépésnek, például a taktikai szinten végrehajtott akció hatást gyakorolhat (pozitivat vagy negativvat) a stratégiai szintre.” (AJP-3.4.4 [2011] 2 - 5. o.) Vagyis számba veszi a normatív különbség kialakulásának lehetőségét, illetve a felkelő csoportok politikai relevanciáját. A harmadik szereplős modell implicit veszélyeit is megállapítja: „A NATO-erők puszta jelenléte vagy a NATO-vezetésü erök hadszintéri fellépése ezt tovább bonyolithatja.” (AJP-3.4.4 [2011] 2 - 5. o.)

Az embereket a felkeléssel kapcsolatos álláspontjuk alapján négy csoportra osztja:

1. Pozitív: A kormányt legitimnek és hasznosnak tartják, támogatják. A kormány és az intézményei általában ide tartoznak. Ebbe a csoportba igyekeznek a felkelők beszivárogni.

2. Semleges: Ide tartoznak azok, akik nem vesznek részt az aktív ellenállásban és nem adják pozitív hozzájárulásukat annak erőfeszítéseihez. A konfliktus ennek a csoportnak bizonytalanságot teremt. Kritikus szerepük lehet a sikerben, történelmileg fontos a megnyerésük. Addig nem támogatják a kormányt, amíg nem biztosak a sikerében.

\footnotetext{
${ }^{155}$ A dokumentum nagy teret szentel annak, hogy milyen tényezőktől függ az államhatalom.

${ }^{156}$ Hat müveleti környezetet különböztet meg, amelyek összefonódnak egymással: politikai, humán, fizikai, biztonsági, információs és gazdasági. (AJP-3.4.4 [2011] 2-4. o.)
} 
3. Negatív: Ellenzik a vendéglátó kormányt, de nem vesznek részt erőszakos cselekményekben. Változatos okok miatt kerülhetnek ebbe a csoportba a szereplők (történelmi, ideológiai, vallási, nacionalista vagy személyes). Politikai megoldáson keresztül akarják az érdekeiket érvényesíteni. Az erőszakos csoportok a maguk oldalára akarják állítani őket, de ez nem jelent automatikus támogatást.

4. Ellenséges: Aktívan és erőszakosan ellenzik a vendéglátó kormányt és a NATO eröket. Az erőszakra legitim eszközként tekintenek, de ezen a csoporton belül is vannak kibékíthető és nem kibékíthető elemek. Az ellenséges csoportok politikai megoldást is kereshetnek az erőszakos mellett. ${ }^{157}$ (AJP-3.4.4 [2011] 2 - 6. o.)

A doktrína a komplex kulturális kapcsolatok és az elitek fogalmán keresztül finomítja a helyi politikai hatalom fogalmát. A kulturális érzékenység és a struktúrák is hangsúlyt kapnak: a doktrína leszögezi a kulturális és vallási különbségek tiszteletben tartását, és hozzáteszi, hogy a helyi kulturális viszonyok megértésén keresztül a helyi tradicionális vezetés megtalálása egyszerüsödhet. (AJP-3.4.4 [2011] $2-6 .-2$ - 7. o.)

\section{Katonai deficit}

Az AJP-3.4.4 igyekszik ötvözni a lakosságközpontú és a harmadik szereplős megközelítéseket: „,Fontos észben tartani, hogy a két legfontosabb elv a felkelésellenes hadviselésben a lakosság védelme és a vendéglátó állam legitimációjának az erösitése. Amikor alacsonyabb vagy támogató célokat kell elérni, a parancsnokoknak tisztában kell lenni azzal, hogy milyen következményei lehetnek ezek aláásásának. Ez föleg akkor lehet kihívás, ha a vendéglátó állam képtelen védelmet és alapvető szolgáltatásokat biztositani a lakosság számára, és széles körben inkompetensnek és/vagy korruptnak vélik." (AJP-3.4.4 [2011] 2 - 12. o.) A megsegített ország legitimációjának védelmét is fontos szempontként kezeli, és a koordináció fontosságát hangsúlyozza a megsegített ország vezetése és a NATO-erők, valamint a nemzetközi szervezetek, a nem kormányzati szervezetek, ${ }^{158}$ a kereskedelmi szervezetek, a privát biztonsági cégek és a média között. (AJP-3.4.4 [2011] 2 - 13. - 2 - 15. o.)

\footnotetext{
157 Összehasonlításképpen: Thompson kormánypárti aktív támogatókról, felkelői aktív támogatókról és semleges rétegről beszél. (Thompson [1966] 63. o.) Galula ugyanezt a felosztást alkalmazza. (Galula [1964] 56-57. o.)

${ }^{158}$ A doktrína itt helyesen rámutat az alapvető feszültségre ezeknek a szervezeteknek a hagyományos küldetése és a hadsereggel való együttmüködés között. (AJP-3.4.4 [2011] 2-14. - 2 - 15 o.)
} 
Az AJP-3.4.4 nagy hangsúlyt helyez az információs területre, és kiemelten fontosnak tartja egy domináns narratíva kialakítását, ami lehetővé teszi a NATO-erők számára, hogy a szélesebb közvélemény felé összehangoltan tudjanak fellépni és bemutatni konkrét történéseket. Rámutat arra is, hogy az ellenséges kommunikáció minden kis hibát fel fog használni arra, hogy a NATO-erők álláspontját aláássa és gyengítse, miközben a felkelő narratíva erősítésére törekszik. Kiemeli, hogy az információs dominancia a megsegített országban végrehajtott műveleteket megkönnyítheti, ehhez azonban az kell, hogy „pontos, tényeken alapuló, aktuális és konzisztens" legyen a kommunikáció, összhangban a domináns narratívával. (AJP-3.4.4 [2011] 2 - 10. o.)

\section{Újdonságok és hiányosságok}

Az AJP-3.4.4 erőssége, hogy a nemzetközi rendszernek azokat a sajátosságait, amelyek közepette sor kerül a konfliktus megvívására, az FM 3-24-hez képest árnyaltabban közelíti meg. A koalíciós fellépés szükségessége és annak potenciális problémái a NATO szövetségi jellegénél fogva nagyobb hangsúllyal szerepeknek benne.

A doktrínában a lakosságközpontú felkelésellenes hadviselés alapvetései folyamatosan és konzisztensen jelen vannak. A dokumentum számos alkalommal felhívja a figyelmet a politikai célok elsőbbségére, és a lakosság biztosítását tekinti a legfontosabb feladatnak. A harmadik szereplős felkelésellenes hadviselés szempontjai is konzekvensen jelen vannak a megsegített állam katonai és bünüldöző intézményeinek nyújtott segítséggel. A percepciókért vívott küzdelem fontos új eleme a doktrínának, és ezzel túlmutat az FM 3-24 tartalmán.

Az FM 3-24-hez viszonyítva kevésbé erőteljes a klasszikus szakasz felkelésellenes elmélettel foglalkozó szerzőire való támaszkodás, ugyanakkor, ahogyan a korábbiakban is jeleztük, a hatásuk egyértelmüen kimutatható.

A doktrína nem követi tételesen, hogy a kortárs felkelöi elmélet milyen változásokon ment át. Bár a függelékben ,új felkelésekről” beszél, sem a kortárs teoretikusok munkáinak elemzése, sem az afganisztáni konfliktus (mint gyakorlati probléma) nem képezi a doktrína részét. Bár röviden szerepelnek benne a főbb felkelöi megközelítések, nem tesz említést a különböző ellenstratégiák sajátosságairól. Nem foglalkozik mérési problémákkal, nem hívja fel a figyelmet a mérési szempontok 
fontosságára sem, így a megfelelő mérési szempontok politikai relevanciája sem szerepel benne.

A doktrína csak nagy vonalakban tárgyalja a taktika kérdéseit. Ez nem feltétlenül hátrány, amennyiben az FM 3-24 mintájára készült mellé taktikai kézikönyv (az FM 324 esetében ez az FM 3-24.2 Taktikák a felkelésellenes müveletekben (Tactics in Counterinsurgency)). A doktrína erőssége, hogy a harmadik szereplős elmélet számos vonatkozását tárgyalja. 


\section{KONKLÚZIÓ}

A felkelésellenes elmélet fejlődésére sok tényező hatott a huszadik században, ezek között a legfontosabbak a nemzetközi rendszerben bekövetkezett változások az erőszak alkalmazásához kapcsolódóan, a belső társadalmi változások a demokráciákban és a nyugati katonai tradíciók átalakulása. A lakosságközpontú felkelésellenes elmélet alapvetően aránytalan fejlődést mutatott: nemzeti keretek között fejlödött és a közvetlen hadszíntérre koncentrált a vizsgált időszak nagy részében, annak ellenére, hogy a kihívások egyre inkább transznacionális jelleget öltöttek. A politikai-katonai együttmüködés sokszor alkalmazkodó jellegü volt, alkalmazkodott a konfliktushoz, nem az elöre lefektetett vonalak mentén haladt. Ez annak a jele, hogy a vizsgált országok sokszor nem rendelkeztek olyan politikai-katonai együttmüködési modellel, amely biztosítani tudta volna a műveletek sikeres végrehajtását. A lakosságközpontú felkelésellenes megközelítést alkalmazó demokráciák közötti információs áramlás és tapasztalatcsere is sok kívánni valót hagyott maga után.

Taktikai és müveleti szinten a fejlődés nem volt egyenes irányú. A briteknél szinte minden vizsgált esetnél komoly taktikai problémákkal nézett szembe a hadsereg a konfliktus elején. Ezeket sokszor rosszul kezelte, néha a konfliktus is elhúzódott. Gyarmati keretek közt, politikai érdekeket figyelembe véve, a birodalom politikai és közigazgatási hátterére támaszkodva igyekezett megvívni a konfliktusait, a mindenkori jogállami szabályok figyelembe vételével. Franciaországban a gyarmati keretek mást jelentettek. A francia hadseregnek jelentősebb szerepe volt a gyarmatosításban, mint a britnek. A második világháború után a forradalmi háború fenyegetését is radikálisan másképp élték meg, mint a britek. A kialakuló DGR-irányzatnál a jogállam kisebb súlyú volt, és a törvénytelen megoldások gyakoribbak. A francia minta azonban a katonai szerep és a kormányzás összekapcsolásához hasznos tapasztalatokat tudott nyújtani a brit tapasztalatokhoz képest. Az amerikai tapasztalatok a preklasszikus időszakban az expedíciós jellegük miatt jelenthettek volna egy plusz tapasztalatforrást, de politikai okokból és intézményi sajátosságok miatt ezeket nem használták fel. A politikai támogatás fontosságát az ilyen expedíciós müveletekhez az amerikai tapasztalatok kellő mértékben alátámasztották. Az amerikai klasszikus szakasz dokrtrínafejlődése arra példa, hogy taktikai szinten, megfelelő körültekintéssel a diktatórikus rendszerek által alkalmazott (ellenségközpontú) taktikákat is át lehet venni, legalább részben. 
Összességében azt mondhatjuk, hogy a lakosságközpontú felkelésellenes elmélet jelenti a mai politikai-jogi-nemzetközi keretek közötti egyetlen elfogadható alternatívát a kialakult felkelések ellen.

A taktikai problémáknak katonai és politikai okai is voltak. A katonaiak részben a klasszikus szerzők által is leírt elfogultságokon alapultak, valamint az egyéb kihívásokkal való birkózás miatti elméleti és erőforrásbeli vetélkedésen. A szerző ezzel nem azt kívánja mondani, hogy a felkelésellenes müveltekkel kapcsolatban szándékos elöítéletek lennének. A két világháború közötti brit hadsereg jó példa arra, hogy milyen problémák lehetnek az uralkodó preferenciákkal szembeni elméleti megközelítésekből. A brit hadsereg rengeteget tett a páncélos fegyvernem fejlődéséért, az elért eredményeket azonban a németek hasznosították. Ennek az az oka, hogy a brit birodalmi vezérkar föparancsnokai - egy kivételtől eltekintve - nem láttak fantáziát a páncélos fegyvernemben, és nem finanszírozták a fejlesztést. Hiába voltak a hadseregen belüli1 ${ }^{159}$ és azon kívüli ,innovátorok”, akik a páncélos fegyvernem fejlesztését a szívükön viselték (legjelesebb képviselőik J. F. C. Fuller és Liddell Hart), és károsnak tartották a fejlesztés leállítását politikai és pénzügyi okok miatt. (Murray [1998] 24-25. o.) De míg a páncélos erök alkalmazása, mint utólag a brit hadsereg számára is nyilvánvaló lett, illeszkedett a konvencionális államközi háborús hagyományba, addig a felkelésellenes műveletek egy másfajta mentalitást és felszerelésrendszert igényelnek. Mivel alapvetően egy másfajta fenyegetésre jelentenek választ, nehezen voltak elfogadtathatók a konvencionális háborúra berendezkedett katonai intézményrendszerekben.

Politikailag a brit rendszer biztosította a legstabilabb kereteket a gyarmati időszakban a felkelésellenes müveletek végrehajtásához. A brit közvélemény jelentős hányada megszokta (ha nem is fogadta el), hogy az időnkénti fegyveres konfliktus a gyarmatokon a nagyhatalmi szereppel jár. A klasszikus időszakban a gyarmati visszavonulással már nem volt ennyire egyértelmü a helyzet, és voltak olyan helyzetek, ahol sem a hadsereg, sem a politikai vezetés nem volt kellő mértékben felkészülve a konfliktus megvívására. Másfelöl a politikai relevancia megnövekedésével is számolnia

\footnotetext{
${ }^{159}$ Percy Hobart vezérörnagy karrierje jó példa arra, hogy komoly karrierre kiható következményei lehettek ennek. Hobart 1938-ban azt a feladatot kapta, hogy állítsa fel az egységet, amiből később a híres 7. páncélos hadosztály lett. De a hadsereg vezetésével megromlott a viszonya a páncélos hadviselés „,erőltetése” miatt, és röviddel a háború kitörése előtt leváltották a hadosztály-parancsnoki posztjáról. 1940-ben a Home Guard-ban szolgált tizedesként, amíg Churchill személyesen be nem avatkozott a sorsába, és követelte a War Department-tol, hogy helyezzék vissza aktív állományba, a vezérkari főnök heves ellenkezese ellenére. A szerepe ezután is erősen korlátozott volt. (Murray [1998] 25. o.)
} 
kellett a brit politikai vezetésnek. A neoklasszikus érában Irak és Afganisztán kapcsán is egyértelmüen a politikai és a katonai célok elválásának lehettünk tanúi. Irakban a brit politikai vezetés célja a jó szövetségi partnerség volt, de a munkáspárti vezetés nem biztosította a szükséges erőforrásokat a vállalt feladathoz, amiben szerepet játszott a feladat nagysága és a háború körülményei miatt a jelentős normatív különbség.

A franciáknál a klasszikus időszakban mind Indokína, mind Algéria esetében szakadék keletkezett a politikai és a katonai vezetés között a stratégia jellegét illetően. Az indokínai háború ideje alatt a francia politikai vezetés egyre növekvő mértékben támaszkodott az amerikai gazdaság támogatására, otthon pedig az erősödő válságban igyekezett fenntartani a győzelem reményét. Az algériai felszabadító háború ügyét teljes mértékben a hadseregre hagyták, és lényegében csak a belpolitikai következmények csökkentésére koncentráltak. Így politikai részről nem gyakorolták a megfelelő kontrollt, ami alkalmas lett volna a Franciaország érdekeivel ellentétes folyamatokat kordában tartani. Ez végső soron oda vezetett, hogy amikor az ellentétek a politikai és a katonai érdekek között nyilvánvalóvá váltak, nyílt szakításra került sor a gyarmaton harcoló hadsereg egy része és a politikai vezetés között. Így történhetett meg, hogy a francia hadsereg annak ellenére, hogy képes volt megtörni a felkelés lendületét, politikailag a háború elvesztését segítette elő az erőszakos fellépésével a francia és a nemzetközi politikai közvélemény előtt. A francia katonai vezetés túl későn jött rá, hogy a konfliktus csak a felkelö számára jelent „totális” háborút, de ekkor már a hadsereg részéről olyan mértékű volt az elköteleződés az algériai terület megtartása mellett, hogy a politikai irányváltás erőszakos ellenreakciót váltott ki a katonai vezetésből.

Az amerikai példa expedíciós tanulságait torzítja, hogy általában nagyon kis számú katonai erő alkalmazására került sor a beavatkozások során, így a csekély instrumentális dependencia a normatív különbség létrejöttét minimalizálta (erre azonban szükség volt azért, mert a brit és a francia példával ellentétben az amerikai politikai vezetés hagyományaival ellentétes volt a gyarmati jellegü megközelítés, még ha a gyakorlatban nem is így látszott). Rossz belpolitikai körülmények között, mint amit a gazdasági világválság eredményezett a harmincas évek elején, nyilvánvalóvá vált a normatív különbség. A nicaraguai fellépés megszakítása látványos példája ennek. A vietnami tapasztalat pedig, ami tekinthető az Egyesült Államok szempontjából az első és utolsó jelentős harmadik szereplős felkelésellenes szerepvállalásnak a hidegháborúban, jól mutatja, hogy a politikának milyen jelentős hatása lehet az elmélet fejlődésére. Ahogyan a történelmi példa mutatja, az amerikai elméletfejlődés a 
gyakorlatban leállt, és a negatív politikai konnotációk miatt a neoklasszikus korszakba lépésnél is a brit és a francia klasszikus időszak gyarmati példái szolgáltak mintául, nem pedig az amerikai minta Vietnamból (ami természetesen nem egyszerűen felkelésellenes konfliktus volt, mai értelemben inkább hibrid konfliktusnak nevezhető, ennek ellenére a jellege miatt számos hasznos tapasztalat lett volna levonható a szerepvállalásból).

A lakosságközpontú felkelésellenes elmélet tapasztalatainak terjedésével kapcsolatban megállapíthatjuk, hogy ez csak korlátozott mértékben történhetett meg addig, amíg létezett egy saját tapasztalatokon alapuló „domináns” nézőpont. A britek elméletfejlődésében például a városi központú felkelések nem szerepeltek az ÉszakÍrországban történő szerepvállalásig, annak ellenére, hogy elsősorban Latin-Amerikában ez a (Marighella nevéhez is társuló) trend érzékelhető volt. A demokratikus berendezkedésű országok tapasztalatcseréi is rejtettek problémákat. Erre talán a leglátványosabb példa a szívek-lelkek (hearts and minds) megközelítés brit és amerikai értelmezése közötti különbség. ${ }^{160}$ A szívek-lelkek megközelítés általában az erőszakmentes lakosságközpontú megközelítéssel egyenértékủ fogalomként vonult be a köztudatba, elsősorban az amerikai értelmezés miatt. Maga a kifejezés Sir Gerald Templer által lett ismert. ${ }^{161}$ A brit megközelítés ${ }^{162}$ azonban távolról sem a soft powert helyezte előtérbe, hanem nagymértékben a kényszer alkalmazására támaszkodott, szemben az amerikaival.

A történelmi tapasztalatokból egyértelmü, hogy a konfliktusok idején a politikaikatonai összhang megteremtése a felkelésellenes müveletek sikeréhez nélkülözhetetlen. A gyarmati keretek, (illetve az USA esetében a nagyhatalmi beavatkozás) megszünésével, valamint a második világháború után a nemzetközi jog és a felkelésekkel kapcsolatos álláspont megváltozásának következtében újfajta stratégiai megközelítés kellett. A felkelésellenes mủveletek kontextusa is megváltozott ennek köszönhetően: alapvetően expedíciós, támogató jelleget kaptak. A politikai célok változása pedig csak bonyolította a kérdést: míg a klasszikus szakaszban alapvetően a

${ }^{160}$ A kifejezés ellentmondásosságát az adja, hogy két értelemben lehet megnyerni a lakosság hủségét: kényszerrel vagy jóindulattal. A jóindulat-értelmezés vált uralkodóvá az utóbbi évtizedben, azonban korántsem egyértelmü, hogy Templer eredeti felfogása is ezt a megközelítést tükrözte volna, mivel a brit erők kényszer alkalmazásához is nagymértékben folyamodtak a „kommunista terroristák” elleni küzdelmükben. (Dixon [2009] 366. o.)

${ }^{161}$ Dixon rámutat, hogy a kifejezésnek voltak korábbi gyökerei, azonban a mai köztudatba Templer vitte be. (Dixon [2009] 361. o.)

${ }^{162}$ Dixon kiemeli, hogy a Briggs terv keretében nagyarányú áttelepítések, letartóztatások, internálások, deportálás, számos, a lakosságot mozgás- és egyéb szabadságában korlátozó intézkedés, valamint túlkapás történt, amit a kor standardjai szerint sem lehetett mérsékeltnek minősíteni. (Dixon [2009] 368. o.) 
status quo biztosítására irányultak ezek a müveletek, addig a neoklasszikus szakaszban már annak megváltoztatására irányuló müveletekben kerültek alkalmazásra, a klasszikus felkelésellenes irodalom számos kiindulópontját aláásva ezzel. Ráadásul a gyarmati keretek szétesésével az átfogó elméleti fejlődés megakadt (ez persze nem a katonai taktikai alkalmazkodásra vonatkozik): csak az utóbbi években a harmadik szereplős felkelésellenes elmélet körvonalazódásával fogalmazódott meg egy olyan keretrendszer, amely a megváltozott nemzetközi viszonyok fontos elemeit alkalmazva a stratégiaitól a taktikai szintig egy átfogó egészként kezelte volna ezeket a mủveleteket.

Az FM 3-24 kisebb mértékben, az AJP-3.4.4 nagyobb mértékben már ezen realitások mentén íródott. Azonban alapvetően a hadműveleti szintre írt doktrínáknak nem lehet célja a katonai-politikai kapcsolatok szabályozása, mindössze figyelembe kell vennie a mindenkori stratégiai realitásokat a hatékony fellépés érdekében.

Ennek fényében kijelentjük, hogy a hipotézis ${ }^{163}$ megerösítést nyert. Bár az elválasztás jórészt történelmi előzményeken alapul, illetve a katonai feladatok sokszínüsége miatt csak korlátozottan lehetne a katonai-politikai integráció ilyen magas szintje kívánatos (és konvencionális konfliktusban potenciálisan hátrányos lenne), nem szabad elvetni az integráció elmélyítését.

A gyenge államokban kialakuló transznacionális fenyegetések elhárításának fontos eleme lehet a jövőben is a felkelésellenes müveletek alkalmazása, így az intézményi tanulságok levonása és megőrzése felettébb fontos lesz a potenciális jövőbeli konfliktusok tanulási folyamatának lerövidítéséhez és a katonai-politikai hatékonyság növeléséhez a konfliktus megoldásában.

A további kutatási irányokat illetően a harmadik szereplős felkelésellenes megközelítés továbbfejlesztésére van lehetőség. Egyfelől a politikai rendszerek és a katonai műveletek egymásra hatásának elmélyültebb vizsgálatával a hatások és azok kezelése hatékonyabban értelmezhetővé válik. Másfelől a harmadik szereplős megközelítés koalíciós trendjének vizsgálatára is van mód, mivel az iraki és az afganisztáni konfliktusok jelentős mennyiségü tapasztalatot szolgáltattak ezen a téren.

Fontos kitétel a disszertáció tanulságainak kontextusba helyezéséhez, hogy a megfelelő doktrína nem fordítódik le automatikusan stratégiai, műveleti vagy taktikai hatékonysággá. A megfelelő színvonalú doktrína csupán a kiindulópontot jelenti ezeknek az eléréshez. A britek iraki példája szolgál itt is intő példaként, akik annak

\footnotetext{
${ }^{163}$ A hipotézis: „, Napjaink felkelésellenes elméletének végrehajtásbeli problémáit az okozza, hogy stratégiai szinten elválasztja egymástól a politikai és a katonai dimenziót."
} 
ellenére, hogy rendelkeztek egy magas színvonalú doktrínával, nem építették azt be kellően a képzésbe, így nem is tudták a gyakorlatban megfelelően érvényesíteni. 


\section{Hivatkozott irodalom}

AAP-6 [2013]: NATO Glossary of Terms and Definitions (English and French), North Atlantic Treaty Organization NATO Standardization Agency (NSA) http://nsa.nato.int/nsa/zPublic/ap/aap6/AAP-6.pdf

Aftergood, Steven [2009]: CIA Guide to Analysis of Insurgency, and Other Resources, Secrecy News from the FAS Project on Government Secrecy, http://blogs.fas.org/secrecy/2009/02/analysis_of_insurgency/

AJP-3.4.4 [2011]: Allied Joint Doctrine for Counterinsurgency (COIN), North Atlantic Treaty Organisation NATO Standardisation Agency (NSA) http://info.publicintelligence.net/NATO-Counterinsurgency.pdf

ALDERSON, Alexander [2009]: The Validity of British Army Counterinsurgency Doctrine after the War in Iraq 2003-2009, Cranfield University Defence Academy College of Management and Technology PhD Thesis https://dspace.lib.cranfield.ac.uk/bitstream/1826/4264/1/100126-AldersonPhD\%20Thesis.pdf

ALDERSON, Alexander [2010]: Britain, in: Rid, Thomas és Keany, Thomas:

Understanding Counterinsurgency: Doctrine, Operations and Challenges, Routledge 28-46. o.

ANDREW, Christopher [2009]: Defence of the Realm: The Authorized History of MI5, Allen Lane

Arreguín-ToFT, Ivan [2001]: How the Weak Win Wars: A Theory of Asymmetric Conflict International Security Vol. 26, No. 1 93-128. o.

Aussaresses, Paul [2004]: The Battle of the Casbah: Terrorism and Counterterrorism in Algeria 1955-1957, Enigma Books

BIRTLE, Andrew James [2006]: U.S. Army counterinsurgency and contingency operations doctrine, 1942-1976, Center of Military History United States Army http://www.history.army.mil/html/books/us_army_counterinsurgency/CMH_7 0-98-1_US\%20Army_Counterinsurgency_WQ.pdf

BIRTLE, Andrew James [2009]: U. S. Army counterinsurgency and contingency operations doctrine, 1860-1941, Center of Military History United States 
Army

http://www.history.army.mil/html/books/070/70-66-1/CMH_Pub_70-66-1.pdf

Boot, Max [2003]: The Savage Wars of Peace: Small Wars and the Rise of American

Power, Basic Books

CALlwell, Charles Edward [1906]: Small Wars. Their Principles and Practice, Harrison and Sons

http://www.history.navy.mil/library/online/small_wars.htm

CAnnon, Michael W. [1989]: The Development of the American Theory of Limited

War, 1945-63, School of Advanced Military Studies United States Army

Command and General Staff College

http://www.dtic.mil/get-tr-doc/pdf?AD=ADA215572

CCO LeXIKOn [2011]: Complex Operations Lexicon, Center for Complex Operations,

National Defense University

http://cco.dodlive.mil/files/2012/09/cco_lexicon.pdf

Cebrowski Arthur K., és GarstKA, John J.: Network-Centric Warfare [1998]: Its

Origin and Future, Proceedings

http://all.net/books/iw/iwarstuff/www.usni.org/Proceedings/Articles98/PROceb rowski.htm

CIA [nincs datálva]: CIA Guide to Analysis of Insurgency, Central Intelligence Agency, http://www.fas.org/irp/cia/product/insurgency.pdf

CigAR, Norman [2008]: Al-Qa'ida's Doctrine for Insurgency: Abd al-Aziz al-Muqrin's

"A Practical Course for Guerrilla War", Potomac Books

CREVELD, Martin van [1991]: The Transformation of War: The Most Radical

Reinterpretation of Armed Conflict Since Clausewitz, Free Press

CREveld, Martin van [2002]: The Sword and the Olive: A Critical History of the Israeli Defense Force, Public Affairs

DADDIS, Gregory A. [2011]: No Sure Victory: Measuring U.S. Army Effectiveness and Progress in the Vietnam War, Oxford University Press

DIXON, Paul [2009]: 'Hearts and Minds'? British Counter-Insurgency from Malaya to Iraq, Journal of Strategic Studies, Vol. 32, No. 3. 353-381. o.

Dobbins, James, Jones, Seth G., Crane, Keith, Degrasse, Beth Cole [2007]: The

Beginner's Guide to Nationbuilding, RAND National Security Research

Division 
http://www.rand.org/content/dam/rand/pubs/monographs/2007/RAND_MG557 .pdf

DoDD 3000.05 [2009]: Department of Defense Instruction Number 3000.05,

Department of Defense

http://www.dtic.mil/whs/directives/corres/pdf/300005p.pdf

DODMAT [2013]: Joint Publication 1-02 Dictionary of Military and Associated Terms,

Department of Defense

http://www.dtic.mil/doctrine/new_pubs/jp1_02.pdf

DuRAND, Etienne de [2010]: France in: Rid, Thomas és Keany, Thomas: Understanding Counterinsurgency: Doctrine, Operations and Challenges, Routledge 11-27. o.

FALL, Bernard B. [1966]: Insurgency Indicators, Military Review, 3-12. o.

http://cgsc.contentdm.oclc.org/utils/getfile/collection/p124201coll1/id/640/file name/641.pdf

FALL, Bernard B. [1998]: The Theory and Practice of Insurgency and

Counterinsurgency, Naval War College Review

http://www.au.af.mil/au/awc/awcgate/navy/art5-w98.htm

FALL, Bernard B. [2002]: Hell in a Very Small Place: The Siege of Dien Bien Phu, Da Capo Press

FALL, Bernard B. [2005]: Street Without Joy: The French Debacle in Indochina,

Stackpole Books

FM 3-0 [2008]: Operations, Headquarters Department of the Army, http://www.army.mil/fm3-0/FM3-0.pdf

FM 3-24 [2006]: Counterinsurgency, Headquarters Department of the Army http://www.fas.org/irp/doddir/army/fm3-24.pdf

FM 90-8 [1986]: Countergerrilla Operations, Headquarters Department of the Army http://www.cgsc.edu/carl/docrepository/FM90_8.pdf

FM 100-5 [1993]: Operations, Headquarters Department of the Army

http://cgsc.contentdm.oclc.org/utils/getfile/collection/p4013coll9/id/49/filenam e/50.pdf

FRENCH, David [2009]: Big Wars and Small Wars between the Wars, 1919-1939 in Strachan, Hew (szerk.): Big Wars and Small Wars: The British Army and the Lessons of War in the 20th Century, Routledge 36-53. o.

Galula, David [1964]: Counter-Insurgency Warfare: Theory and Practice, Frederick A. Praeger, 
http://armyrotc.missouri.edu/pdfs-docs/Galula\%20David\%20-

$\% 20$ Counterinsurgency\%20Warfare.pdf

General STAFF [1909]: Field Service Regulations Part I: Operations, War Office http://ia600300.us.archive.org/17/items/pt1fieldservicer00greauoft/pt1fieldserv icer00greauoft.pdf

Gerges, Fawaz A. [2009]: The Far Enemy: Why Jihad Went Global, Cambridge University Press

GiUstozzI, Antonio [2008]: Koran, Kalashnikov, and Laptop: The Neo-Taliban Insurgency in Afghanistan 2002-2007, Columbia University Press

GolDSTEIN, Gordon M. [2009]: Lessons in Disaster: McGeorge Bundy and the Path to War in Vietnam, Holt Paperbacks

Gordon, Michael R. és Trainor, Bernard E. [2007]: Cobra II: The Inside Story of the Invasion and Occupation of Iraq, Vintage Books

Gooch, Brison D. [1997]: Bugeaud, Thomas-Robert, Marshal, Duc D'Isly 1784-1849

Encyclopedia of Revolutions of 1848, Ohio University

http://www.ohio.edu/chastain/ac/bugeaud.htm

GuevarA, Ernesto Che [2007]: A gerillaharcos kézikönyve, Ulpius ház

GuTTIERI, Karen [2010]: Metrics in Iraq's Complex Environment in: Gregg, Heather S., Rothstein, Hy S. és Arquilla, John: The Three Circles of War: Understanding the Dynamics of Conflict in Iraq, Potomac Books

Gwynn, Charles W. [1939]: Imperial Policing, MacMillan and Company http://www.combatreform.org/PENTOMICARMYAGAIN/imperialpolicing.ht $\mathrm{m}$

Hammes, Thomas X. [2006]: The Sling and the Stone: On War in the 21st Century, Zenith

HAMmES, Thomas X. [2007]: Fourth Generation Warfare Evolves, Fifth Emerges, Military Review 14-23. o.

http://cgsc.contentdm.oclc.org/utils/getfile/collection/p124201coll1/id/162/file name/163.pdf

HARVEY, Derek J. [2005]: A Red Team Perspective on the Insurgency in Iraq, in: McGrath, John (szerk.) An Army at War: Change in the Midst of Conflict, http://www.cgsc.edu/carl/download/csipubs/AnArmyAtWar_ChangeInTheMid stOfConflict.pdf 
Herrington, Stuart A. [2004]: Stalking the Vietcong: Inside Operation Phoenix: A Personal Account, Ballantine Books

HofFMAN, Frank G. [2007]: Neoclassical Counterinsurgency? Parameters http://strategicstudiesinstitute.army.mil/pubs/parameters/articles/07summer/hof fman.pdf

HooD, Ronald Chalmers III [2010]: Bitter Victory: French Military Effectiveness during the Second World War in Millett, Allan R. és Murray, Williamson: Military Effectiveness Vol 3.: The Second World War, Cambridge University Press 221-255. o.

HoRne, Alistair [2006]: A Savage War of Peace: Algeria 1954-1962, New York Review of Books

ICRC [1949a]: Convention [III] relative to the Treatment of Prisoners of War. Geneva, 12 August 1949. harmadik cikkely http://www.icrc.org/ihl/WebART/375-590006

ICRC [1949b]: Convention [III] relative to the Treatment of Prisoners of War. Geneva, 12 August 1949. negyedik cikkely http://www.icrc.org/ihl/WebART/375-590007?OpenDocument

IW JOC2 [2010]: Irregular Warfare: Countering Irregular Threats Joint Operating Concept, http://www.dtic.mil/futurejointwarfare/concepts/iw_joc2_0.pdf

Joint PubliCATION 3-07 [1995]: Joint Doctrine for Military Operations Other Than War, Joint Chiefs of Staff http://cgsc.contentdm.oclc.org/utils/getfile/collection/p4013coll9/id/874/filena me/875.pdf

Joint Publication 3-26 [2009]: Counterterrorism, Department of Defense, Joint Chiefs of Staff http://www.fas.org/irp/doddir/dod/jp3_26.pdf

JONES, Tim [2007]: Postwar Counterinsurgency and the SAS 1945-1952: A Special Type of Warfare, Routledge

KARDOS Gábor és LATTMANN Tamás (szerk.) [2010]: Nemzetközi jog, ELTE Eötvös Kiadó

KILCULLEN, David [2006]: Counterinsurgency Redux, Survival: Global Politics and Strategy, Volume 48, Issue 4, http://www.au.af.mil/au/awc/awcgate/uscoin/counterinsurgency_redux.pdf 
KILCULLEN, David [2010]: Counterinsurgency, Hurst

KITSON, Frank [1960]: Gangs and Counter-Gangs, Barrie and Rockliff http://www.kalasnyikov.hu/dokumentumok/frank-kitson-gangscountergangs.pdf

KITSON, Frank [1991]: Low Intensity Operations: Subversion, Insurgency, Peacekeeping, Faber and Faber http://libcom.org/files/low-intensity\%20operations.pdf

KRULAK, Charles C. [1999]: The Strategic Corporal: Leadership in the Three Block War, Marines Magazine http://www.au.af.mil/au/awc/awcgate/usmc/strategic_corporal.htm

LEDWIDGE, Frank [2012]: Losing Small Wars: British Military Failure in Iraq and Afghanistan, Yale University Press

LEWIS, Adrian R. [2006]: The American Culture of War: A History of US Military Force from World War II to Operation Enduring Freedom, Routledge LIA, Brynjar [2010]: Jihadi Strategists and Doctrinarians in Editors: Assaf Moghadam, Brian Fishman: Self-Inflicted Wounds Debates and Divisions within al-Qa'ida and its Periphery, Harmony Projevct Combating Terrorism Center at West Point

http://www.ctc.usma.edu/wp-content/uploads/2011/05/Self-InflictedWounds.pdf

LIND, William S., Nightengale, Keith, Schmitt, John F., Sutton, Joseph W., Wilson, Gary I. [1989]: The Changing Face of War: Into the Fourth Generation, Marine Corps Gazette http://www.mcamarines.org/files/The\%20Changing\%20Face\%20of\%20War\%20\%20Into\%20the\%20Fourth\%20Generation.pdf

LINN, Brian McAlister [2009]: The Echo of Battle: The Army's Way of War, Harvard University Press

LutTWAK, Edward N. [2006]: Modern War: Counter-Insurgency as Malpractice, Politique étrangère www.ifri.org/files/politique_etrangere/luttwak.pdf

MACK, Andrew [1975]: Why Big Nations Lose Small Wars: The Politics of Asymmetric Conflict, World Politics Vol 27. Issue 2 
http://www.stanford.edu/class/polisci211z/2.2/Mack\%20WP\%201975\%20Asy mm\%20Conf.pdf

MACKINLAY, John [2005]: Defeating Complex Insurgency, The Cornwallis Group http://thecornwallisgroup.org/pdf/CX_2005_03-MackinlayJ.pdf

MAson, R. Chuck [2009]: U.S.-Iraq Withdrawal/Status of Forces Agreement: Issues for Congressional Oversight, Congressional Research Service https://www.fas.org/sgp/crs/natsec/R40011.pdf

MASON, R. Chuck [2012]: Status of Forces Agreement (SOFA): What Is It, and How Has It Been Utilized? Congressional Research Service https://www.fas.org/sgp/crs/natsec/RL34531.pdf

MAO Tse-tung [1989]: On Guerrilla Warfare, U.S. Marine Corps, Fleet Marine Force Reference Publication [FMFRP] 12-18 http://www.marines.mil/Portals/59/Publications/FMFRP\%201218\%20\%20Mao\%20Tse-tung\%20on\%20Guerrilla\%20Warfare.pdf

MAO Tse-tung [2004]: On Protracted War, Selected Works of Mao Tse-tung https://www.marxists.org/reference/archive/mao/selected-works/volume2/mswv2_09.htm

MARIGHELla, Carlos [2002]: Mini-Manual of the Urban Guerrilla, Abraham Guillen Press \& Arm the Spirit

MCNAMARA, Robert [1964]: Memorandum for the President by Robert McNamara, "South Vietnam," The Pentagon Papers https://www.mtholyoke.edu/acad/intrel/pentagon3/doc158.htm

MEARSHEIMER, John [2005]: Hans Morgenthau and the Iraq war: realism versus neoconservatism, Open Democracy http://www.opendemocracy.net/democracyamericanpower/morgenthau_2522.jsp

Merom, Gil [2003]: How Democracies Lose Small Wars: State, Society, and the Failures of France in Algeria, Israel in Lebanon, and the United States in Vietnam, Cambridge University Press

MetZ, Steven és Johnson, Douglas V. II [2001]: Asymmetry and U.S. Military Strategy: Definition, Background, and Strategic Concepts, Strategic Studies Institute http://www.strategicstudiesinstitute.army.mil/pubs/download.cfm?q=223 
METZ, Steven és KIEVIT, James [1995]: Strategy and the Revolution in Military Affairs:

From Theory to Policy, Strategic Studies Institute

http://www.strategicstudiesinstitute.army.mil/pubs/download.cfm?q=236

Ministry of DefEnce [2009]: British Army Field Manual, Volume 1 Part 10,

Countering Insurgency,

news.bbc.co.uk/2/shared/bsp/hi/pdfs/16_11_09_army_manual.pdf

MOYAR, Mark [2007]: Phoenix and the Birds of Prey: Counterinsurgency and

Counterterrorism in Vietnam, Bison Books

MSSI [2010]: Measuring Stability and Security in Iraq, Department of Defense,

http://www.defense.gov/pubs/pdfs/June_9204_Sec_Def_signed_20_Aug_2010

.pdf

MSSI [2005]: Measuring Stability and Security in Iraq, Department of Defense, http://www.defense.gov/news/Jul2005/d20050721secstab.pdf

MuRRAY, Williamson [1998]: Armored Warfare: The British, French and German experiences in: Murray, Williamson és Millett, Allan R. (szerk.) [1998]:

Military Innovation in the Interwar Period, Cambridge University Press 6-49. o.

NAGL, John A. [2005]: Learning to Eat Soup with a Knife: Counterinsurgency Lessons from Malaya and Vietnam, Chicago University Press

NAJI, Abu Bakr [2006]: The Management of Savagery: The Most Critical Stage

Through Which the Umma Will Pass, John M. Olin Institute for Strategic

Studies at Harvard University

http://ics-

www.leeds.ac.uk/papers/pmt/exhibits/2800/Management_of_Savagery.pdf

NDS [2005]: National Defense Strategy of the Untied States of America, Department of

Defense

http://www.defense.gov/news/mar2005/d20050318nds1.pdf

O’NeILL, Bard E. [2005]: Insurgency and Terrorism: From Revolution to Apocalypse, Potomac Books Inc.

PHILLIPS, R. Cody [2004]: Operation JUST CAUSE: The Incursion Into Panama, U.S. Army Center of Military History http://www.history.army.mil/html/books/070/70-85-1/cmhPub_70-85-1.pdf

PORTER, Patrick [2009]: Military Orientalism: Eastern War Through Western Eyes, C Hurst \& Co Publishers 
QDR [2006]: Quadrennial Defense Review Report, Department of Defense http://www.defense.gov/qdr/report/Report20060203.pdf

RENNIE, James [2009]: The Operators: On the Streets with Britain's Most Secret Service, Pen and Sword Military Classics

RID, Thomas [2009]: Razzia: A Turning Point in Modern Strategy, Terrorism and Political Violence 21/4, 617-635. o. http://thomasrid.org/wp-content/uploads/2009/11/rid-razzia1.pdf

RID, Thomas [2010]: The Nineteenth Century Origins of Counterinsurgency Doctrine, Journal of Strategic Studies, Journal of Strategic Studies Volume 33, Issue 5, 727-758. o.

RUMSFELD, Donald H. [2002]: Transforming the Military, Foreign Affairs http://www.foreignaffairs.com/articles/58020/donald-h-rumsfeld/transformingthe-military

SARKEES, Meredith Reid [2010]: Codebook for the Intra-State Wars v.4.0.: Definitions and Variables, Correlates of War http://www.correlatesofwar.org/COW2\%20Data/WarData_NEW/IntraStateWars_Codebook.pdf

SCHMITT, Carl [2006]: Theorie des Partisanen: Zwischenbemerkung zum Begriff des Politischen, Duncker \& Humblot

SHARP, Gene [nincs datálva]: 198 Methods of Nonviolent Action, The Albert Einstein Institution http://www.aeinstein.org/organizations/org/198_methods.pdf

SimPSON, Erin Marie [2010]: The Perils of Third-Party Counterinsurgency Campaigns, [disszertáció] Harvard University http://dissexpress.umi.com/dxweb/doc/816350138.html?FMT=AI\&desc=The+ Perils+of+Third-Party+Counterinsurgency+Campaigns

Singer, David és SMALL, Melvin [2010a]: Inter-State War Data, Correlates of War http://www.correlatesofwar.org/COW2\%20Data/WarData_NEW/ListInterStateWars.pdf

SiNGER, David és SMALL, Melvin [2010b]: Intra-State War Data, Correlates of War http://www.correlatesofwar.org/COW2\%20Data/WarData_NEW/IntraStateWarData_v4.1.csv

SMITH, Rupert [2008]: Utility of Force: The Art of War in the Modern World, Vintage 
SORELY, Lewis [1999]: A Better War: The Unexamined Victories and Final Tragedy of America's Last Years in Vietnam, Harcourt

COMBATING TERrorism CENTER [2010]: The Rules of Jihad established for Mujahideen by the Leadership of Afghanistan Islamic Emirates,

http://www.ctc.usma.edu/wp-content/uploads/2010/10/AFGP-2007-K0000029Trans-Meta.pdf

Thompson, Robert Grainger Ker [1966]: Defeating Communist Insurgency: The Lessons of Malaya and Vietnam, F. A. Praeger

TILFORD, Earl H. Jr. [1991]: Setup: What the Air Force Did in Vietnam and Why, Air University Press

http://www.dtic.mil/cgi-

bin/GetTRDoc?AD=ADA421969\&Location=U2\&doc=GetTRDoc.pdf

TRINQUIER, Roger [1985]: Modern Warfare: A French View of Counterinsurgency, Combat Studies Institute http://armyrotc.missouri.edu/pdfs-docs/Roger\%20Trinquier\%20\%20Modern\%20Warfare.pdf

UrBAN, Mark [2011]: Task Force Black: The Explosive True Story of the SAS and the Secret War in Iraq, Abacus 


\section{Rövidítések jegyzéke}

4GW: (US) negyedik generációs hadviselés (fourt generation warfare)

5GW: (US) ötödik generációs hadviselés (fifth generation warfare)

ACR: (US) páncélos lovasezred (Armored Cavalry Regiment)

AID: (US) Nemzetközi Fejlesztési Ügynökség (Agency for International Development)

AJP: (NATO) Szövetséges Összhaderőnemi Publikációjával (Allied Joint Publication)

ALN: Nemzeti Felszabadítási Hadsereg (Armeé de Libération Nationale)

ARVN: (VN) dél-vietnami hadsereg (Army of Republic Viet Nam)

ATOM: (GB) A terroristaellenes müveletek végrehajtása Malájföldön (The

Conduct of Anti-Terrorist Operations in Malaya)

BAOR: (GB) rajnai brit hadsereg (British Army of the Rhine)

CIA: (US) Központi Hírszerző Hivatal (Central Intelligence Agency)

CAP: (US-VN) Többnemzeti Bevetési Szakasz program (Combined Action Platoon)

CIDG: (US-VN) Civil Irreguláris Védelmi Csoportok (Civil Irregular Defense Groups)

COIN: felkelésellenes müvelet (Counterinsurgency)

CORDS: (US-VN) Polgári Müveletek és Forradalmi Fejlesztési Támogatás (Civil Operations and Revoultionary Development Support)

COSVN: (VN) Kommunista Párt Dél-vietnami Központi Irodája (Communist

Party'S Central Office for South Vietnam)

DGR: (Fr) forradalmi hadviselés doktrína (Doctrine de la guerre révolutionnaire)

DMI: (GB) Katonai Hírszerzési Igazgatóság (Directorate of Military Intelligence)

D.O.P.: (Fr) Műveleti Védelmi Különítmény (Détachement Opérationnel de Protection)

D.P.U.: (Fr) Városi Védelmi Harccsoport (Dispoitif de protection urbaine)

ENSZ: Egyesült Nemzetek Szervezete

FID: (US) külföldi belső védelem (Foreign Internal Defense)

FINI: Fall-féle nem katonai indikátorok (Fall Insurgency Nonmilitary Indicators)

FLN: Nemzeti Felszabadítási Front (Front de Libération Nationale) 
FM: (US) harctéri kézikönyv (Field Manual)

FMI: (US) ideiglenes harctéri kézikönyv (Field Manual Interim)

FSR: (GB) harctéri szolgálati szabályzat (Field Service Regulation)

G.C.M.A.: (Fr) Vegyes Ejtőernyős Kommandó Csoportok (Groupements de Commandos Mixtes Aéroportés)

G.M.I.: (Fr) Vegyes Beavatkozó Csoportok (Groupement Mixte d'Intervention)

IDAD: (US) belső védelem és fejlesztés (internal defense and development)

IED: (GB, US) improvizált robbanóeszköz (Improvized Explosive Device)

IMF: Nemzetközi Valutaalap (International Monetary Fund)

JAM: Mahdi Hadserege (Jaysh al-Mahdi)

JP: (US) Összhaderőnemi Publikáció (Joint Publication)

JWS: Dzsungel Hadviselési Iskola (Jungle Warfare School)

MACP: (GB) Észak-írországi Katonai Támogatás a Polgári Hatalomnak

(Northern Ireland-Military Assistance to the Civil Power)

NLF: (VN) Népi Felszabadítási Front (National Liberation Front)

MND(SE): (GB, US) Dél-keleti Többnemzeti Hadosztály (Multi-National

Division (South-East))

MI5: (GB) Katonai Elhárítás (Military Intelligence 5)

MI6: (GB) Katonai Hírszerzés (Military Intelligence 6)

MITT: mobil integrált kiképzőcsoport (Mobile Integrated Training Team)

MOOTW: (US) nem háborús katonai müveletek (Military Operations Other Than War)

NISOPs: (GB) Észak-írországi Hatályos Műveleti Eljárások (Northern Ireland Standing Operating Procedures)

NITAT: (GB) Észak-írországi Kiképző és Tanácsadó Csoport (Northern Ireland Training and Advisory Team)

NLF: (VN) Népi Felszabadítási Front (National Liberation Front)

OAS: (Fr) Titkos Hadsereg Szervezete (Organisation Armée Secrète)

OOTW: (US) nem háborús müveletek (Operations other than War)

OSS: (US) Stratégiai Szolgálatok Hivatala (Office of Strategic Services)

RAF: (GB) Királyi Légierő (Royal Air Force)

RIMA: (Fr) tengerészgyalogsági ezred (régiment d'infanterie de marine)

RMA: (US) Katonai Ügyek Forradalma (Revolution in Military Affairs) 
ROAD: (US) Átszervezési Célok Hadsereg Hadosztály (Reorganization Objectives Army Division)

RVNAF: (VN) Vietnami Köztáraság Fegyveres Erői (Republic of Vietrnan Armed Forces)

SAS: (Fr) Speciális Adminisztratív Egységek (Section Administratives Specialisées)

SAS: (GB) Különleges Légi Szolgálat (Special Air Service)

SBS: (GB) Különleges Tengeri Szolgálat (Special Boat Service)

SDECE: (Fr) Külső Dokumentációs és Kémelhárító Szolgálat (Service de Documentation Extérieure et de Contre-Espionnage)

SEER: (US-VN) Vietnami Fegyveres Erők Hatékonyságának Felmérési

Rendszere (System for Evaluating the Effectivenes of RVNAF)

SNS: (GB) Különleges Éjszakai Raj (Special Night Squad)

SOE: (GB) Különleges Mủveleti Szolgálat (Special Operations Executive)

SOTAT: (GB) Biztonsági Müveleti Kiképző és Tanácsadó Csoport (Security Operations Training and Advisory Team)

TFES: (US-VN) Területi Erők Felmérési Rendszere (Territorial Forces Evaluation System)

TRADOC: (US) Kiképzési és Doktrína Parancsnokság (Training and Doctrine Command)

UNHCR: Egyesült Nemzetek Menekültügyi Főbiztossága (United Nations High Commissioner for Refugees)

WTO: Világkereskedelmi Szervezet (World Trade Organization) 


\section{Publikációs jegyzék}

\section{Könyvfejezet}

Kemény János [2008]: Merre tart az iszlám harci mozgalom? Társadalmi Tanulmányok. ELTE TáTK Hallgatói Önkormányzat évkönyve. Budapest. 113-145. o.

Kemény János [2009]: Biztonsági vákuum kialakulásának körülményei Irakban az amerikai megszállás első szakaszában (2003. április - 2003. szeptember). Társadalmi Tanulmányok. ELTE TáTK Hallgatói Önkormányzat évkönyve. Budapest. 81-112. o. http://tatkhok.elte.hu/sites/default/files/tt_2009.pdf

\section{Referált szakmai folyóirat}

Kemény János [2005]: Az al-Kaida mozgalom. Hadtudomány XV. évfolyam 1. szám. 107-117. o.

http://www.zmne.hu/kulso/mhtt/hadtudomany/2005/1/2005_1_8.html

Kemény János [2006]: A terroristák kiadatása és a terrorizmusellenes háború. Hadtudomány XVI. évfolyam 3. szám.

http://www.zmne.hu/kulso/mhtt/hadtudomany/2006/3/2006_3_10.html

Kemény János [2007]: Az USA terrorizmusellenes háborújának kezdete. Hadtudomány XVII. évfolyam 1. szám. 41-50. o.

http://www.zmne.hu/kulso/mhtt/hadtudomany/2007/1/2007_1_6.html

Háda Béla - Kemény János [2008]: Az iraki és a Srí Lanka-i harci csoportok kommunikációs tevékenységének összehasonlítása. Hadtudomány. elektronikus szám http://www.zmne.hu/kulso/mhtt/hadtudomany/2008_e_8.pdf

Kemény János [2008]: Amerika terrorizmusellenes háborúja közelről (recenzió). Nemzet és Biztonság I. évfolyam 4. szám. 91-94. o. 
http://www.nemzetesbiztonsag.hu/cikkek/kemeny_janos-

amerika_terrorizmus_elleni_haboruja_kozelr__l.pdf

Kemény János [2008]: Az Iraki Szabadság-hadmüvelet tervezése. Nemzet és Biztonság I. évfolyam 8. szám. 32-43. o.

http://www.nemzetesbiztonsag.hu/cikkek/kemeny_janos-

az_iraki_szabadsag_hadmuvelet_tervezese.pdf

Kemény János [2010]: Az iraki hadsereg feloszlatása (2003. május). Hadtudomány XX. évfolyam 1-2. szám. 71-84. o.

http://mhtt.eu/hadtudomany/2010/1_2/2010_1_2_Kemeny.pdf

Kemény János [2011]: Az amerikai-iraki védelmi együttmüködés helyzete napjainkban. Nemzet és Biztonság IV. évfolyam 10. szám. december, 56-66. o.

http://www.nemzetesbiztonsag.hu/cikkek/kemeny_janos-

az_amerikai__iraki_vedelmi_egyuttmukodes_helyzete_napjainkban.pdf

\section{Egyéb}

Kemény János [2007]: Az iszlám harci mozgalom kortárs teoretikusai. Felderítő Szemle VI. évfolyam 2. szám. 42-58. o.

http://www.kfh.hu/publikaciok/2007-2.pdf

Kemény János [2008]: Kihallgatási módszerek és eljárások a terrorizmus elleni küzdelemben. Felderítő Szemle VII. évfolyam 1. szám. 67-80. o.

http://www.kfh.hu/publikaciok/2008-1.pdf

Kemény János [2009]: Bush elnöksége a Fehér Házból nézve (recenzió). Társadalom és Politika 2009/3.

Kemény János [2009]: A Bush-adminisztráció, az Amerikai Hírszerző Közösség, és az iraki háború megindításának indokai, Öt kontinens. Az ELTE Új- és Jelenkori Egyetemes Történeti Tanszék tudományos közleményei. Budapest. 267-277. o. 
http://tortenelemszak.elte.hu/data/23437/mKemeny.pdf

Kemény János [2010]: Az amerikai hadsereg felkelés-ellenes műveletei Irakban. Társadalom és Politika 2010/2. 27-50. o.

Kemény János [2012]: Donald H. Rumsfeld amerikai védelmi miniszter Afganisztánról és Irakról 2003.02.14. (dokumentumközlés)

http://www.grotius.hu/doc/pub/WHOTRD/2012_6_donald_h._rumsfeld.pdf

\section{Angol nyelvü könyvfejezet}

Kemény János [2010]: State of the (European) Union. In: Palánkai Tibor (ed.): Studies on European Integration 3. Measurement of Integration - Integration Profiles. Savaria University Press. Szombathely. 199-209. o. 